DANIELLE DINIZ ATAYDE

SISTEMAS DE ROTAÇÃO DE CULTURAS E INFECÇÃO

DE GRÃOS DE MILHO POR Fusarium verticillioides EM

REGIÕES PRODUTORAS NO ESTADO DE SÃO PAULO

Tese apresentada ao Programa de Pós-Graduação em Microbiologia do Instituto de Ciências Biomédicas da Universidade de São Paulo, para obtenção do título de Doutor em Ciências. 
DANIELLE DINIZ ATAYDE

\section{SISTEMAS DE ROTAÇÃO DE CULTURAS E INFECÇÃO \\ DE GRÃOS DE MILHO POR Fusarium verticillioides EM \\ REGIÕES PRODUTORAS NO ESTADO DE SÃO PAULO}

Tese apresentada ao Programa de Pós-Graduação em Microbiologia do Instituto de Ciências Biomédicas da Universidade de São Paulo, para obtenção do título de Doutor em Ciências.

Área de concentração: Microbiologia

Orientador: Prof. Dr. Benedito Corrêa

Versão original 
DADOS DE CATALOGAÇÃO NA PUBLICAÇÃO (CIP)

Serviço de Biblioteca e Informação Biomédica do

Instituto de Ciências Biomédicas da Universidade de São Paulo

reprodução não autorizada pelo autor

Atayde, Danielle Diniz.

Sistemas de rotação de culturas e infecção de grãos de milho por Fusarium verticillioides em regiões produtoras no estado de São Paulo / Danielle Diniz Atayde. -- São Paulo, 2013.

Orientador: Prof. Dr. Benedito Correa.

Tese (Doutorado) - Universidade de São Paulo. Instituto de Ciências Biomédicas. Departamento de Microbiologia. Área de concentração: Microbiologia. Linha de pesquisa: Ciência e Tecnologia de Alimentos.

Versão do título para o inglês: Crop rotation systems and infection of maize grains by Fusarium verticillioides in maize-producing regions in the state of São Paulo.

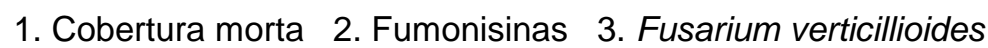
4. Micobiota 5. Milho 6. Rotação de culturas I. Correa, Prof. Dr. Benedito II. Universidade de São Paulo. Instituto de Ciências Biomédicas. Programa de Pós-Graduação em Microbiologia III. Título. 
Candidato(a): Danielle Diniz Atayde.

Título da Tese: $\quad$ Sistemas de rotação de culturas e infecção de grãos de milho por Fusarium verticillioides em regiões produtoras no estado de São Paulo.

Orientador(a): $\quad$ Prof. Dr. Benedito Correa.

A Comissão Julgadora dos trabalhos de Defesa da Tese de Doutorado, em sessão pública realizada a considerou
( ) Aprovado(a)
( ) Reprovado(a)

\begin{tabular}{|c|c|}
\hline Examinador(a): & $\begin{array}{l}\text { Assinatura: } \\
\text { Nome: ....... } \\
\text { Instituição: }\end{array}$ \\
\hline Examinador(a): & $\begin{array}{l}\text { Assinatura: } \\
\text { Nome: ....... } \\
\text { Instituição: }\end{array}$ \\
\hline Examinador(a): & $\begin{array}{l}\text { Assinatura: } \\
\text { Nome: ........ } \\
\text { Instituição: }\end{array}$ \\
\hline Examinador(a): & $\begin{array}{l}\text { Assinatura: } \\
\text { Nome: ....... } \\
\text { Instituição: }\end{array}$ \\
\hline Presidente: & $\begin{array}{l}\text { Assinatura: } \\
\text { Nome: ........ } \\
\text { Instituição: }\end{array}$ \\
\hline
\end{tabular}




\section{CERTIFICADO DE ISENÇÃO}

Certificamos que o Protocolo CEP-ICB N $\mathbf{3 7 1 / 1 0}$ referente ao projeto intitulado: "Influência de um sistema de rotação de culturas sobre a diversidade microbiana do solo e a infecção de grãos de milho, soja e sorgo por Fusarium verticillioides" sob a responsabilidade de Danielle Diniz Atayde, foi analisado na presente data pela CEUA COMISSÃO DE ÉTICA NO USO DE ANIMAIS e pela CEPSH- COMISSÃO DE ÉTICA EM Pesquisa com seres humanos, tendo sido deliberado que o referido projeto não envolve manipulação animal ou humana que justifique uma aprovação quanto aos princípios éticos exigidos por ambas as Comissões.

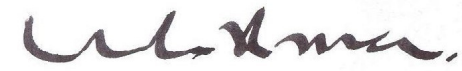

PROF. DR. WOTHAN TAVARES DE LIMA Coordenador da CEUA - ICB/USP
São Paulo, 20 de abril de 2010.

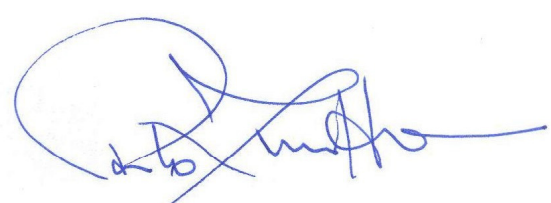

PROF. DR. PAOLO M.A ZANOTTO Vice=Coordenador da CEPsh - ICB/USP 
Aos meus pais e minha irmã, pelo carinho e por sempre acreditarem em mim, me dando força para seguir em frente.

Amo vocês! 


\section{AGRADECIMENTOS}

Ao professor e orientador Dr. Benedito Corrêa, pela oportunidade, pela orientação, amizade e também pelos exemplos de honestidade e dedicação pela profissão, os quais terão minha eterna admiração.

À Universidade de São Paulo, Instituto de Ciências Biomédicas e aos professores do Departamento de Microbiologia, pelos valiosos ensinamentos e conhecimentos adquiridos.

Ao Instituto de Agronomia de Campinas (IAC) e a Agência Paulista de Tecnologia dos Agronegócios (APTA), Pólo Regional Médio Paranapanema - Assis e Pólo Regional Sudoeste Paulista - Capão Bonito, pelo suporte necessário oferecido para realização do projeto.

Aos membros da banca examinadora, pela contribuição e atenção dispensada na correção desta Tese.

Aos meus pais, Helyette e Alziro, pelo amor, compreensão, por sempre acreditarem e confiarem em mim, pelo incentivo e investimento na minha formação.

A minha irmã Vanessa, amiga de todas as horas, que mesmo morando tão longe, está presente na minha vida todos os dias, me apoiando, dando força, exemplo e amor.

À Babi, que, desde que surgiu na minha vida, nunca mais me deixou sem um sorriso no rosto.

A todos meus familiares, pelo apoio, palavras de incentivo e por encherem minha vida de alegria e energia positiva.

Ao Dr. Aildson Pereira Duarte e a Dra. Vera Lúcia Nishijima Paes de Barros, pela colaboração e atenção durante a realização do trabalho.

A Tatiana Alves dos Reis, pelo auxílio técnico nas análises, amizade e ensinamentos fundamentais para minha formação. 
A Mariana Sconza Soncin, minha eterna filhota, aluna de iniciação científica, estagiária e amiga, a quem devo muito deste trabalho e serei eternamente grata por toda boa vontade e interesse.

Aos amigos do Laboratório de Micotoxinas e Instituto de Ciências Biomédicas, Patrícia, Tainah, Rodrigo, Ludmila, Márcia, Raquel, Liliana, Cynara, Gabriela, Arianne, Ednei, Vinícius de Moraes, Vinícius Schievano, Priscilla, Maitê, Lívia, Sabina e Aline pelo inestimável auxílio e ótima convivência.

Equipe APTA Pólo Regional Sudoeste Paulista (Capão Bonito) e APTA Pólo Regional Médio Paranapanema (Assis): Edimilson, Rita, Evaldo, José Angelino, Cesarino e Noel.

As secretárias Gisele, Elizabeth e Naíde, sempre muito prestativas e atenciosas.

A toda equipe técnica da esterilização do nosso departamento, pelo auxílio prestado.

A Fundação de Amparo a Pesquisa do Estado de São Paulo (FAPESP) pelo suporte financeiro.

A Deus, pela vida e pela força.

Enfim, a todos que colaboraram direta e indiretamente para a realização deste trabalho. 
"Os que se encantam com a prática sem a ciência são como os timoneiros que entram no navio sem timão nem bússola, nunca tendo certeza do seu destino." (Leonardo da Vinci) 


\section{RESUMO}

ATAYDE, D. D. Sistemas de Rotação de Culturas e Infecção de Grãos de Milho por Fusarium verticillioides em Regiões Produtoras no Estado de São Paulo. 2013. 127 f. Tese (Doutorado em Microbiologia) - Instituto de Ciências Biomédicas, Universidade de São Paulo, São Paulo, 2013.

Propomos neste estudo avaliar a influência da rotação de culturas na infecção de grãos de milho e cobertura morta por Fusarium verticillioides e na presença de fumonisinas em amostras de milho provenientes de duas regiões produtoras no Estado de São Paulo, Palmital e Capão Bonito. As coletas de amostras de cobertura morta foram realizadas antes da semeadura do milho e as de milho, realizadas após maturidade fisiológica dos grãos. Para o isolamento fúngico, foram utilizadas as técnicas Semeadura em Superfície (meio DG18 Ágar Base Dicloran Glicerol Cloranfenicol) e Semeadura Direta (meio DRBC - Ágar Dicloran Rosa Bengala Cloranfenicol), para as amostras de cobertura morta e milho, respectivamente. Os fungos isolados nesta pesquisa foram identificados em nível de gênero, entretanto, aqueles pertencentes ao gênero Fusarium foram identificados até espécie, utilizando métodos clássicos e moleculares. Para a análise micotoxicológica das amostras de grãos, utilizamos Cromatografia Líquida de Alta Eficiência (CLAE). A atividade de água (Aa) média nas amostras de cobertura morta e milho foi 0,62 e 0,91 em Palmital e 0,48 e 0,96 em Capão Bonito, respectivamente. A micobiota da cobertura morta revelou maior frequência de isolamento de Cladosporium spp. nas duas regiões e coletas (Palmital: $1^{\mathrm{a}}$ coleta - 37,8\% / $2^{\mathrm{a}}$ coleta - 65,2\%; Capão Bonito: $1^{\mathrm{a}}$ coleta $-58,4 \% / 2^{\mathrm{a}}$ coleta $-82,9 \%$ ). Nas amostras de milho, $F$. verticillioides foi o fungo mais isolado nas duas regiões e coletas (Palmital: $1^{\text {a }}$ coleta - 38,6\% / $2^{\mathrm{a}}$ coleta - 70,3\%; Capão Bonito: $1^{\mathrm{a}}$ coleta - 30,5\% / $2^{\mathrm{a}}$ coleta - 69,2\%). Dentro do gênero Fusarium, a espécie $F$. verticillioides $(72,5 \%)$ foi a mais frequente, seguida por $F$. bulbicola $(7,7 \%), F$. graminearum $(6,1 \%), F$. andiyazi $(4,2 \%), F$. semitectum $(2,9 \%), F$. proliferatum $(2,2 \%), F$. subglutinans $(1,6 \%), F$. oxysporum $(1,3 \%), F$. incarnatum $(0,9 \%), F$. poae $(0,3 \%)$ e $F$. sacchari $(0,3 \%)$. Análise micotoxicológica do milho proveniente de Palmital revelou a presença de fumonisinas $\left(\mathrm{FB}_{1}+\mathrm{FB}_{2}\right)$ em 88,9\% das amostras (níveis de 16,5 a $7.410,9 \mu \mathrm{g} / \mathrm{kg}$ ), e em Capão Bonito, $86,1 \%$ das amostras estavam contaminadas (de 15,1 a $495,0 \mu \mathrm{g} / \mathrm{kg}$ ). Foi realizada a verificação da potencialidade toxigênica quanto à produção de $\mathrm{FB}_{1}$ e $\mathrm{FB}_{2}$ em 227 cepas de $F$. verticillioides isoladas de amostras de cobertura morta e grãos de milho. Verificou-se que $51,1 \%$ produziram apenas $\mathrm{FB}_{1}$ e $33,5 \%$ produziram ambas as fumonisinas $\left(\mathrm{FB}_{1}+\mathrm{FB}_{2}\right)$. Os níveis de $\mathrm{FB}_{1}$ variaram de 59,8 a $57.174,1 \mu \mathrm{g} / \mathrm{Kg}$ e os de $\mathrm{FB}_{2}$ variaram de 53,0 a 40.021,9 $\mu \mathrm{g} / \mathrm{Kg}$. A presença de $F$. verticillioides e fumonisinas nos grãos de milho estabelece um problema econômico e de saúde pública. Desta forma, tornam-se necessárias pesquisas minuciosas nesta área, incluindo a utilização de sementes geneticamente modificadas mais resistentes e a rotação de culturas como métodos para controle das doenças, além da determinação de meios rápidos e eficazes na detecção destes micro-organismos, como também a adoção de boas práticas de cultivo para a diminuição dos riscos de contaminação dos alimentos.

Palavras-chave: Cobertura morta. Fumonisinas. Fusarium verticillioides. Micobiota. Milho. Rotação de culturas. 


\begin{abstract}
ATAYDE, D. D. Crop Rotation Systems and Infection of Maize Grains by Fusarium verticillioides in Maize-Producing Regions in the State of São Paulo. 2013. 127 p. Ph. D. thesis (Microbiology) - Instituto de Ciências Biomédicas, Universidade de São Paulo, São Paulo, 2013.
\end{abstract}

The objective of this study was to evaluate the influence of crop rotation on the infection of maize grains and mulch with Fusarium verticillioides and on the presence of fumonisins in maize samples collected in two maize-producing regions in the State of São Paulo (Palmital and Capão Bonito). Samples of mulch were collected before planting maize, and maize samples were collected after physiological maturity of the grains. Surface seeding (DG18 Dichloran Glycerol Agar Base with chloramphenicol) and direct seeding (DRBC - Dichloran Rose Bengal Chloramphenicol Agar) were used for fungal isolation from mulch and maize samples, respectively. The fungi isolated were identified to genus level; however, fungi belonging to the genus Fusarium were identified to species level using classical and molecular methods. High-performance liquid chromatography (HPLC) was used for mycotoxicological analysis of the grain samples. The mean water activity $\left(\mathrm{A}_{\mathrm{w}}\right)$ was 0.62 and 0.91 for mulch and maize samples from Palmital, respectively, and 0.48 and 0.96 for those collected in Capão Bonito. Analysis of the mycobiota in mulch revealed a higher frequency of isolation of Cladosporium spp. in both regions and samplings (Palmital: $1^{\text {st }}$ sampling $-37.8 \%$, $2^{\text {nd }}$ sampling $-65.2 \%$; Capão Bonito: $1^{\text {st }}$ sampling $-58.4 \%, 2^{\text {nd }}$ sampling $\left.-82.9 \%\right)$. In maize samples, $F$. verticillioides was the most frequently isolated fungus in both regions and samplings (Palmital: $1^{\text {st }}$ sampling $-38.6 \%, 2^{\text {nd }}$ sampling $-70.3 \%$; Capão Bonito: $1^{\text {st }}$ sampling $-30.5 \%, 2^{\text {nd }}$ sampling $\left.-69.2 \%\right) . F$. verticillioides $(72.5 \%)$ was the most frequently isolated Fusarium species, followed by $F$. bulbicola $(7.7 \%), F$. graminearum $(6.1 \%), F$. andiyazi (4.2\%), F. semitectum (2.9\%), F. proliferatum (2.2\%), F. subglutinans (1.6\%), F. oxysporum $(1.3 \%), F$. incarnatum $(0.9 \%), F$. poae $(0.3 \%)$, and $F$. sacchari $(0.3 \%)$. Mycotoxicological analysis of maize from Palmital revealed the presence of fumonisins $\left(\mathrm{FB}_{1}+\mathrm{FB}_{2}\right)$ in $88.9 \%$ of the samples (levels ranging from 16.5 to $7,410.9 \mu \mathrm{g} / \mathrm{kg}$ ), and Capão Bonito, $86.1 \%$ of the samples were contaminated (15.1 to $495.0 \mu \mathrm{g} / \mathrm{kg}$ ). The toxigenic potential $\left(\mathrm{FB}_{1}\right.$ and $\mathrm{FB}_{2}$ production) was analyzed in $227 \mathrm{~F}$. verticillioides strains isolated from mulch and maize grain samples. Of these, $51.1 \%$ produced only $\mathrm{FB}_{1}$ and $33.5 \%$ produced both fumonisins $\left(\mathrm{FB}_{1}+\right.$ $\mathrm{FB}_{2}$ ). $\mathrm{FB}_{1}$ levels ranged from 59.8 to $57,174.1 \mu \mathrm{g} / \mathrm{kg}$ and $\mathrm{FB}_{2}$ levels from 53.0 to $40,021.9$ $\mu \mathrm{g} / \mathrm{kg}$. The presence of $F$. verticillioides and fumonisina in maize grains can be considered a economic problem and public health. These findings indicate the need for detailed research in this area, including the use of more resistant genetically modified seeds and crop rotation as measures for disease control. In addition, faster and more effective methods for the detection of these microorganisms need to be developed and good agricultural practices should be adopted to reduce the risk of food contamination.

Keywords: Mulch. Fumonisins. Fusarium verticillioides. Mycobiota. Maize. Crop rotation. 


\section{LISTA DE ILUSTRAÇÕES}

Figura 1 Anatomia do grão de milho e suas partes............................................. 21

Figura 2 Milho e seus derivados........................................ 22

Figura 3 Estrutura química das fumonisinas.................................................. 32

Figura $4 \quad$ Mecanismo de ação das fumonisinas.................................................. 33

Figura 5 Esquema da inserção do gene cry no genoma do milho e a ação das toxinas Bt no intestino médio de insetos suscetíveis.............................. 38

Figura 6 Mapa do Estado de São Paulo, identificando os municípios onde foram realizados os experimentos

Figura 7 Coleta de amostra de cobertura morta na região de Capão Bonito............

Figura 8 Coleta de amostra de cobertura morta em Capão Bonito

Figura 9 Coleta de amostra de cobertura morta na região de Palmital.................. 46

Figura 10 Coleta de amostra de cobertura morta em Palmital................................ 46

Figura 11 Coleta de amostra de grãos de milho na região de Palmital.................... 47

Figura 12 Amostra de milho coletado em Palmital............................................. 48

Figura 13 Coleta de amostra de grãos de milho na região de Capão Bonito............ 48

Figura 14 Coleta de amostras de milho em Capão Bonito..................................... 49

Figura 15 Aparelho Aqualab CX-2 _............................................................. 50

Figura 16 Técnica da semeadura direta para o isolamento da micobiota dos grãos de milho.

Figura 17 Semeadura em superfície para o isolamento da micobiota das amostras de cobertura morta..

Figura 18 Sequências do gene TEF-1 $\alpha$ dos isolados de Fusarium spp. editadas no software BioEdit Sequence Alignment Editor.. 
Figura 19 Alinhamento das sequências do gene TEF-1 $\alpha$ dos isolados de Fusarium 56 spp. no banco de dados do Fusarium ID v1.0.

Figura 20 Espécies de Fusarium spp. identificadas em amostras de cobertura morta e de grãos de milho, nas duas regiões estudadas.

Figura 21 Dados climatológicos [índice pluviométrico $(\mathrm{mm})$, temperaturas máxima média $\left({ }^{\circ} \mathrm{C}\right)$ e mínima média $\left.\left({ }^{\circ} \mathrm{C}\right)\right]$ referentes ao período de outubro/2010 a março/2012 registrados na região de Palmital - SP.....

Figura 22 Dados climatológicos [índice pluviométrico $(\mathrm{mm})$, temperaturas máxima média $\left({ }^{\circ} \mathrm{C}\right)$ e mínima média $\left.\left({ }^{\circ} \mathrm{C}\right)\right]$ referentes a out/2010 a mar/2012 registrados em Capão Bonito 80

Figura A.1 Curva de calibração 1 para fumonisina $\mathrm{B}_{1}\left(\mathrm{FB}_{1}\right)$

Figura A.2 Curva de calibração 1 para fumonisina $\mathrm{B}_{2}\left(\mathrm{FB}_{2}\right)$

Figura A.3 Curva de calibração 2 para fumonisina $\mathrm{B}_{1}\left(\mathrm{FB}_{1}\right)$

Figura A.4 Curva de calibração 2 para fumonisina $\mathrm{B}_{2}\left(\mathrm{FB}_{2}\right)$ 


\section{LISTA DE TABELAS}

Tabela 1 Histórico de uso da área (2009/10) e descrição da sequência de culturas por época e tratamento, em Palmital (SP).

Tabela 2 Histórico de uso da área (2009/10) e descrição da sequência de culturas por época e tratamento, em Capão Bonito (SP).

Tabela 3 Quantidade de amostras de cobertura morta e de grãos de milho coletadas, divididas em duas coletas, e quantidade total de amostras analisadas de cada região.

Tabela 4 Concentração das soluções para a curva de calibração 1

Tabela 5 Concentração das soluções para a curva de calibração 2 .

Tabela 6 Frequência de isolamento fúngico (\%), número de $\mathrm{UFC} / \mathrm{g}$ (Unidades Formadoras de Colônias por grama de substrato) e atividade de água (Aa) média das amostras de Cobertura Morta - $1^{\text {a }}$ coleta de Palmital (outubro/2010).

Tabela 7 Frequência de isolamento fúngico (\%), número de UFC/g (Unidades Formadoras de Colônias por grama de substrato) e atividade de água (Aa) média das amostras de Cobertura Morta - $2^{\mathrm{a}}$ coleta de Palmital (outubro/2011).

Tabela 8 Frequência de isolamento fúngico (\%) e atividade de água (Aa) média das amostras de Grãos de Milho - $1^{a}$ coleta (safra verão 2010/2011) na região de Palmital.

Tabela 9 Frequência de isolamento fúngico (\%) e atividade de água (Aa) média das amostras de Grãos de Milho - última coleta (safra verão 2011/2012) na região de Palmital.

Tabela 10 Frequência de isolamento fúngico (\%), número de UFC/g (Unidades Formadoras de Colônias por grama de substrato) e atividade de água (Aa) média das amostras de Cobertura Morta - $1^{\text {a }}$ coleta de Capão Bonito (outubro/2010).

Tabela 11 Frequência de isolamento fúngico (\%), número de UFC/g (Unidades Formadoras de Colônias por grama de substrato) e atividade de água (Aa) média das amostras de Cobertura Morta - $2^{\text {a }}$ coleta de Capão Bonito (setembro/2011) 
Tabela 12 Frequência de isolamento fúngico (\%) e atividade de água (Aa) média das amostras de Grãos de Milho - $1^{\text {a }}$ coleta (safra verão 2010/2011) em Capão Bonito.

Tabela 13 Frequência de isolamento fúngico (\%) e atividade de água (Aa) média das amostras de Grãos de Milho - última coleta (safra verão 2011/2012) na região de Capão Bonito.

Tabela 14 Correlação entre a frequência de $F$. verticillioides, a porcentagem de amostras contaminadas por fumonisinas $\left(\mathrm{FB}=\mathrm{FB}_{1}+\mathrm{FB}_{2}\right)$ e a concentração média de fumonisinas nas amostras de grãos de milho coletadas em Palmital.

Tabela 15 Correlação entre a frequência de $F$. verticillioides, a porcentagem de amostras contaminadas por fumonisinas $\left(\mathrm{FB}=\mathrm{FB}_{1}+\mathrm{FB}_{2}\right)$ e a concentração média de fumonisinas nas amostras de grãos de milho coletadas em Capão Bonito.

Tabela 16 Precipitação pluvial mensal e valores médios de temperaturas mínima e máxima em Palmital e Capão Bonito.

Tabela 17 Estatísticas descritivas para a variável "isolamento de $F$. verticillioides no milho", em porcentagem de grãos contaminados (33 grãos analisados por amostra).

Tabela 18 Estatísticas descritivas para a variável "isolamento de $F$. verticillioides na cobertura morta”, x $10^{4}$ Unidades Formadoras de Colônias por grama de substrato $(\mathrm{UFC} / \mathrm{g})$.

Tabela 19 Estatísticas descritivas para a variável "detecção de $\mathrm{FB}_{1}$ ", em $\mu \mathrm{g} / \mathrm{kg}$...........

Tabela 20 Estatísticas descritivas para a variável “detecção de $\mathrm{FB}_{2}$ ”, em $\mu \mathrm{g} / \mathrm{kg}$.

Tabela 21 Estatísticas descritivas para a variável "atividade de água no milho".

Tabela 22 Estatísticas descritivas para a variável "atividade de água na cobertura morta".

Tabela 23 Estimativas e valores-p do ajuste do modelo de regressão beta binomial inflacionado no zero para a variável "isolamento de $F$. verticillioides no milho".

Tabela 24 Valores-p das variáveis não incluídas no modelo de regressão beta binomial inflacionado no zero para a variável "isolamento de $F$. verticillioides no milho". 
Tabela 25 Estimativas e valores-p do ajuste do modelo de regressão Weibull para a 86 variável "nível de $\mathrm{FB}_{1}$ no milho".

Tabela 26 Valores-p das variáveis não incluídas no modelo de regressão Weibull para a variável "nível de $\mathrm{FB}_{1}$ no milho".

Tabela 27 Comparações múltiplas no modelo de regressão Weibull para a variável "nível de $\mathrm{FB}_{1}$ no milho"

Tabela 28 Estimativas e valores-p do ajuste do modelo de regressão Gaussiana inversa inflacionado no zero para a variável "níveis de $\mathrm{FB}_{2}$ no milho".

Tabela 29 Valores-p das variáveis não incluídas no modelo de regressão Gaussiana inversa inflacionado no zero para a variável "níveis de $\mathrm{FB}_{2}$ no milho"

Tabela B.1 Concentração de fumonisinas $\mathrm{B}_{1}$ e $\mathrm{B}_{2}$ em $\mu \mathrm{g} / \mathrm{Kg}$ (ppb) em 144 amostras de grãos de milho recém-colhido das regiões de Palmital e Capão Bonito..

Tabela B.2 Verificação da potencialidade toxigênica quanto à produção de fumonisinas $B_{1}$ e $B_{2}$ em $\mu \mathrm{g} / \mathrm{Kg}$ (ppb) em 227 cepas de $F$. verticillioides isoladas de amostras de grãos de milho recém-colhido e cobertura morta das regiões de Palmital e Capão Bonito 


\section{SUMÁRIO}

1 INTRODUÇÃO E REVISÃO DE LITERATURA.............................................. 20

1.1 Milho

1.2 Cobertura Morta

1.3 Micobiota

1.4 Fusarium verticillioides.................................................................................... 27

1.5 Micotoxinas..................................................................................... 29

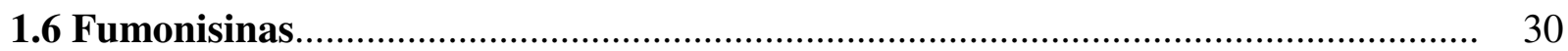

1.7 Métodos para Controle das Doenças Fúngicas...................................................... 35

1.7.1 Rotação de culturas ........................................................................................... 35

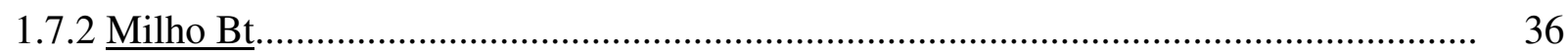

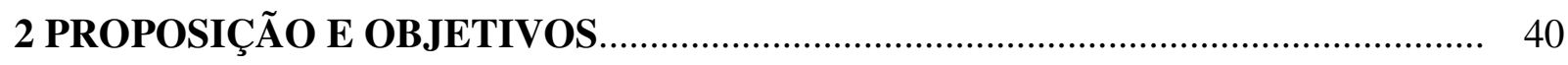

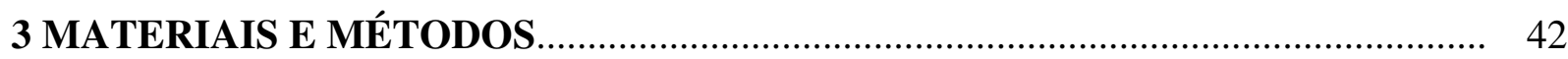

3.1 Caracterizações das Unidades Experimentais........................................................ 42

3.2 Tratamentos e Delineamento Experimental......................................................... 42

3.3 Parcelas Experimentais...................................................................................... 44

3.4 Cultivares e tratos culturais..........................................................................

3.5 Amostragens................................................................................................... 44

3.5.1 Cobertura morta

3.5.2 Grãos de milho........................................................................................ 47

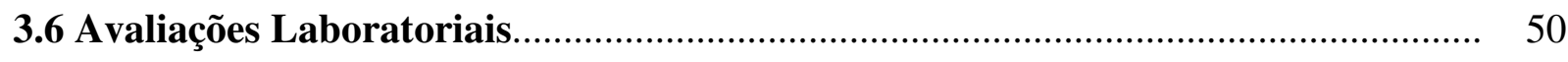

3.6.1 Determinação de Atividade de água (Aa).................................................................. 50

3.6.2 Técnica da Semeadura Direta para o Isolamento da Micobiota dos Grãos de

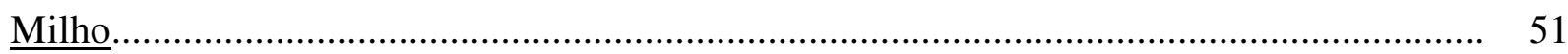

3.6.3 Técnica da Semeadura em Superfície para o Isolamento da Micobiota das Amostras de Cobertura Morta.................................................................................................... 51

3.6.4 Identificação dos Isolados de Fusarium spp. pelo Sequenciamento Parcial do Gene

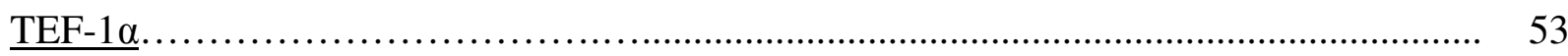

3.6.4.1 Extração de DNA Genômico........................................................... 53

3.6.4.2 Quantificação do DNA Genômico de Fusarium spp. ............................................. 53

3.6.4.3 Reação de Polimerase em Cadeia (PCR) do Gene TEF-1a................................. 54 
3.6.4.4 Purificação do DNA .............................................................. 54

3.6.4.5 Quantificação da PCR purificada ......................................................................... 55

3.6.4.6 Reação de Sequenciamento do Produto de PCR do Gene TEF-1 $\alpha$............................ 55

3.6.4.7 Precipitação das Reações de Sequenciamento....................................................... 55

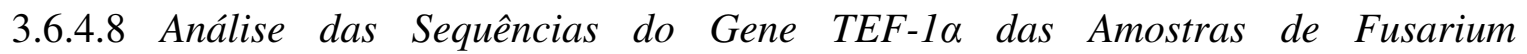

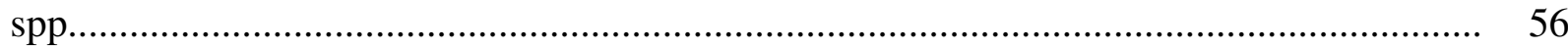

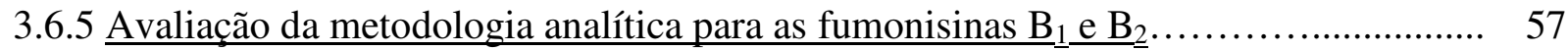

3.6.5.1 Construção das curvas de calibração.............................................. 57

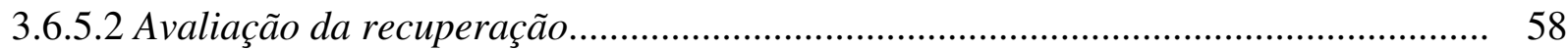

3.6.5.3 Determinação do limite de quantificação............................................................. 58

3.6.6 Determinação de Fumonisinas das Amostras de Milho................................................. 58

3.6.6.1 Extração e Purificação de Fumonisinas das Amostras............................................ 58

3.6.6.2 Cromatografia Líquida de Alta Eficiência................................................................ 59

3.6.7 Avaliação do Potencial Toxigênico das Cepas de F. verticillioides Isoladas Durante

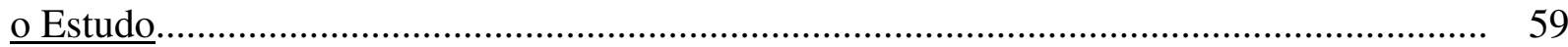

3.6.7.1 Extração e Purificação de Fumonisinas das Cepas Isoladas.................................... 59

3.6.7.2 Cromatografia Líquida de Alta Eficiência- CLAE .................................................... 60

3.7 Análise dos Fatores Climatológicos das Regiões..................................................... 60

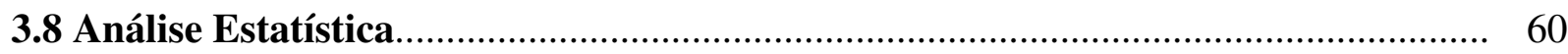

4 FLUXOGRAMA

5 RESULTADOS

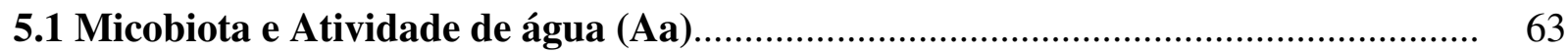

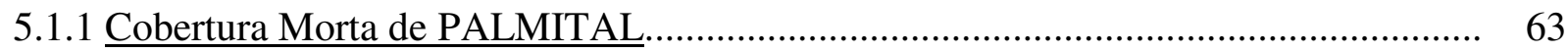

5.1.1.1 $1^{a}$ coleta (realizada em outubro/2010, antes do plantio do milho safra verão 2010/2011)

5.1.1.2 $2^{a}$ coleta (realizada em outubro/2011, antes do plantio do milho safra verão 2011/2012).

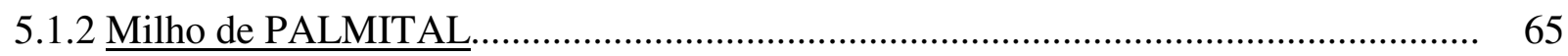

5.1.2.1 $1^{a}$ coleta (safra verão 2010/2011, coletada em fevereiro/2011).............................. 65

5.1.2.2 Segunda e Última coleta (safra verão 2011/2012, coletada em

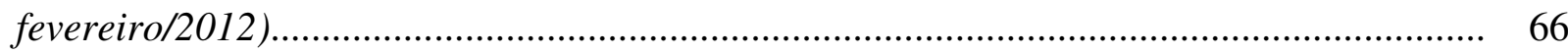

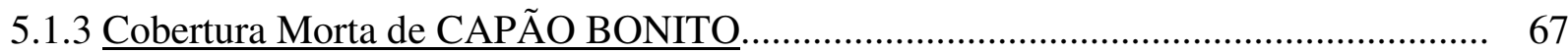


5.1.3.1 $1^{a}$ coleta (realizada em outubro/2010, antes do plantio do milho safra verão 2010/2011)

5.1.3.2 $2^{a}$ coleta (realizada em setembro/2011, antes do plantio do milho safra verão 2011/2012)

5.1.4 Milho de CAPÃO BONITO

5.1.4.1 $1^{a}$ coleta (safra verão 2010/2011, coletada em março/2011).

5.1.4.2 $2^{a}$ e ultima coleta (safra verão 2011/2012, realizada em março/2012).

5.2 Identificação das espécies do gênero Fusarium por metodologia clássica e molecular.

5.3 Avaliação da metodologia analítica para determinação das fumonisinas $B_{1} e$ $\mathbf{B}_{2}$.

5.4 Determinação de Fumonisinas das Amostras de Milho.

5.5 Avaliação do Potencial Toxigênico das Cepas de $F$. verticillioides Isoladas Durante o Estudo.

5.6 Análise dos Fatores Climatológicos das Regiões de Estudo. 77

5.7 Análise Estatística. 81

5.7.1 Análise exploratória. 81

5.7.2 Análise inferencial. 84

5.7.2.1 Análise do isolamento de F. verticillioides..... 85

5.7.2.2 Análise dos níveis de $F B_{1}$ nas amostras de grãos de milho. 85

5.7.2.3 Análise dos níveis de $\mathrm{FB}_{2}$ nas amostras de grãos de milho..... 88

6 DISCUSSÃO. 90

6.1 Micobiota e Atividade de água das Amostras de Cobertura Morta. 90

6.2 Micobiota de Atividade de água das Amostras de Grãos de Milho.

6.3 Identificação das espécies de Fusarium spp. isoladas das amostras de cobertura morta e grãos de milho de ambas as regiões.

6.4 Avaliação da metodologia analítica para determinação das fumonisinas $B_{1} e$ $\mathbf{B}_{2}$.

6.5 Determinação de fumonisinas $B_{1}$ e $B_{2}$ nas amostras de grãos de milho

6.6 Avaliação do potencial toxigênico das cepas de $F$. verticillioides isoladas das amostras de cobertura morta e grãos de milho. 


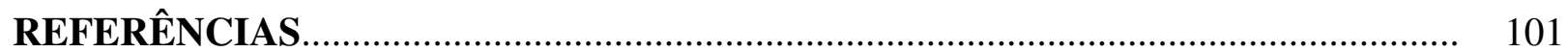

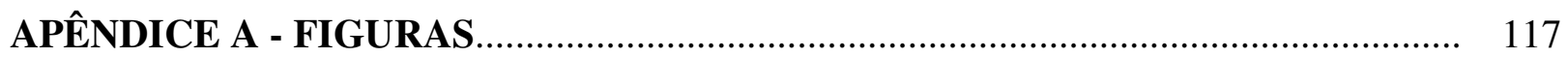

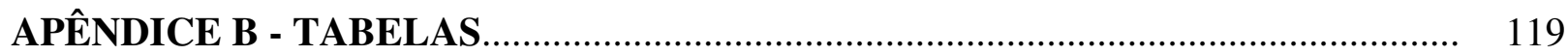




\section{INTRODUÇÃO E REVISÃO DE LITERATURA}

\subsection{Milho}

O milho é uma monocotiledônea pertencente à família Poaceae, gênero Zea, espécie Zea mays L. (BENSON; PEARCE, 1987). Segundo Pohl (2007), o início da cultura do milho data cerca de 7000 anos atrás na região do Golfo do México, sendo descendente da planta Teosinto Mexicana (Zea mays subsp. Iltis e DoebBley).

Antes do descobrimento da América, o milho (Zea mays L.) constituía, dentre os vegetais, a base alimentícia dos indígenas que aqui viviam sendo cultivado desde a Argentina até o Canadá. Logo após a descoberta da América, o milho foi levado para a Espanha, Portugal, França e Itália, onde a princípio era cultivado em jardins, como planta exótica e ornamental. Uma vez conhecido seu valor alimentício, passou a ser produzido em escala comercial e difundiu-se para o resto da Europa, Ásia e Norte da África (MOURA; OLIVEIRA, 1980). Hoje é uma planta cultivada em regiões quentes e temperadas do mundo todo. Representa uma das principais culturas da agricultura brasileira não somente no aspecto quantitativo, mas também devido à sua importância como base na alimentação animal e humana (LÓPEZ-OVEJERO et al., 2004).

Os grãos do milho são, geralmente, amarelos ou brancos, podendo apresentar colorações variando desde o preto até o vermelho. Conhecido botanicamente como uma cariopse, o grão é formado por quatro principais estruturas físicas: endosperma, gérmen, pericarpo (casca) e ponta (Figura 1), as quais diferem em composição química e também na organização dentro do grão (PAES, 2006). O endosperma representa aproximadamente 83\% do peso seco do grão, consistindo principalmente de amido (88\%), organizado na forma de grânulos. No endosperma estão também presentes as proteínas de reserva (8\%) do tipo prolaminas, chamadas zeínas, e, na camada de aleurona, estão presentes os carotenóides, substâncias lipídicas que conferem a cor aos grãos. Zeaxantina, luteína, betacriptoxantina, alfa e beta carotenos são os principais carotenóides nos grãos de milho. O gérmen representa $11 \%$ do grão de milho e concentra quase a totalidade dos lipídeos (óleo e vitamina E) (83\%) e dos minerais (78\%) do grão, além de conter quantidades importantes de proteínas (26\%) e açúcares (70\%) (PAES, 2006). O pericarpo é a parede celular do gametófito maduro e compreende as camadas celulares externas que envolvem o endosperma e o embrião (GIBBON; LARKINS, 2005). Representa, em média, 5\% do grão, sendo a estrutura que protege as demais estruturas da elevada umidade do ambiente, insetos e microrganismos. A 
ponta é a menor estrutura, $2 \%$ do grão, e é responsável pela conexão do grão ao sabugo, sendo a única área do grão não coberta pelo pericarpo. Sua composição é essencialmente de material lignocelulósico (PAES, 2006).

Figura 1 - Anatomia do grão de milho e suas partes.

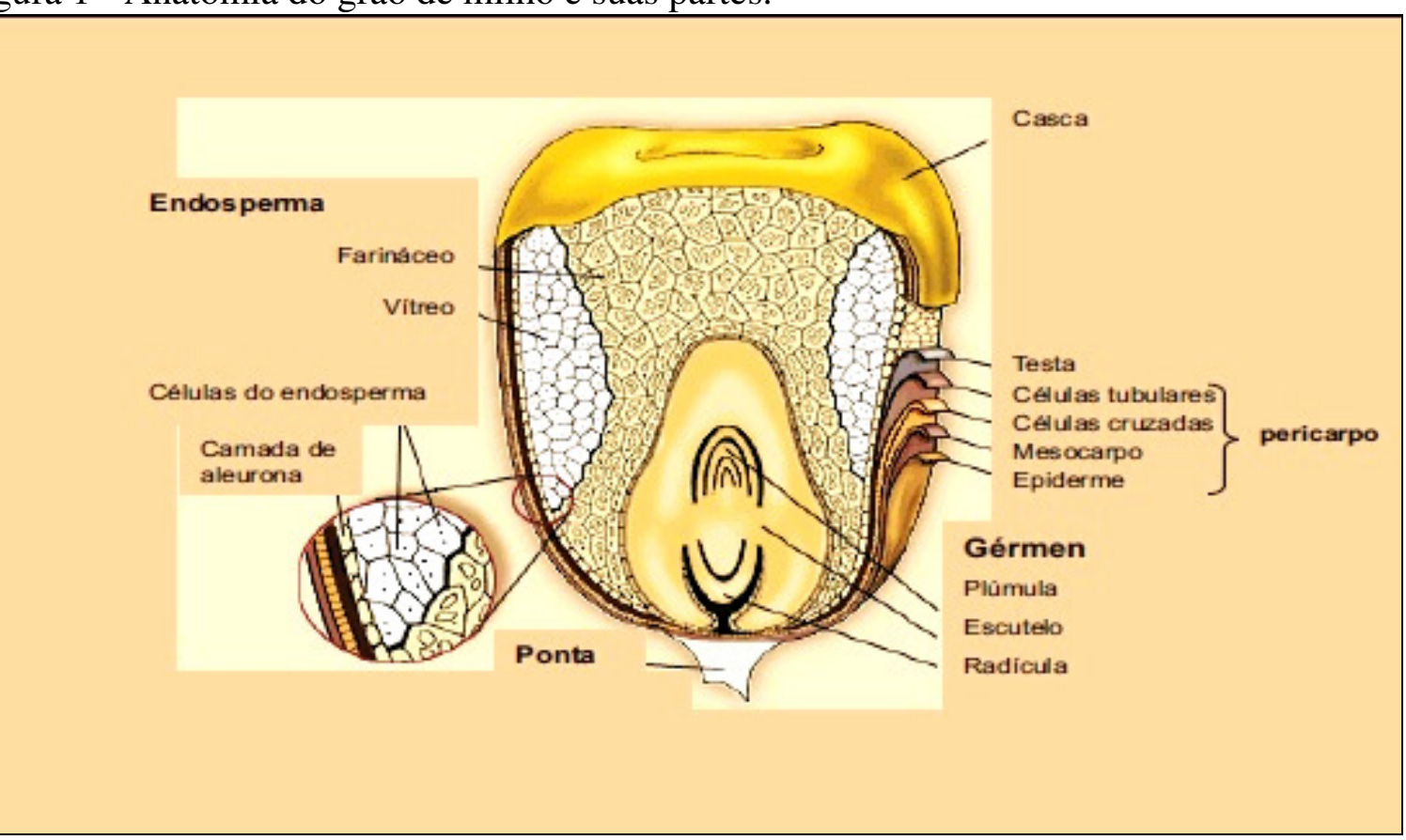

Fonte: Paes, 2006.

Devido sua constituição - em média, $72 \%$ amido, $9,5 \%$ de proteínas, $9 \%$ de fibras, $4 \%$ de lipídeos, além de minerais e vitaminas - o milho é utilizado no preparo de mais de 500 derivados, sendo a base de produtos alimentares diversificados, bem como relevante fator sócio-econômico para muitas regiões do mundo (FANCELLI, 1986; PAES, 2006). Cerca de $70 \%$ da produção mundial de milho é destinada à alimentação animal, podendo este percentual chegar a $85 \%$, em países desenvolvidos. Em termos gerais, apenas $15 \%$ de toda a produção mundial destina-se ao consumo humano, de forma direta ou indireta (PAES, 2006) (Figura 2).

Atualmente, a China é o maior produtor de milho no mundo (ZHANG et al., 2013). O cultivo mundial de milho anualmente abrange cerca de 150 milhões de hectares, com produção oscilando de 550 a 581 milhões de toneladas. O Brasil é o terceiro maior produtor e consumidor de milho, superado pelos Estados Unidos da América (EUA) e China, e disputa com a Ucrânia a posição de terceiro país maior exportador do cereal, superado pelos EUA e Argentina (COMPANHIA NACIONAL DE ABASTECIMENTO, 2012). Na safra 
2013/2014, o Brasil obteve produção de 79 milhões de toneladas em uma área cultivada de 16 milhões de hectares (CONAB, 2013).

Figura 2 - Milho e seus derivados.

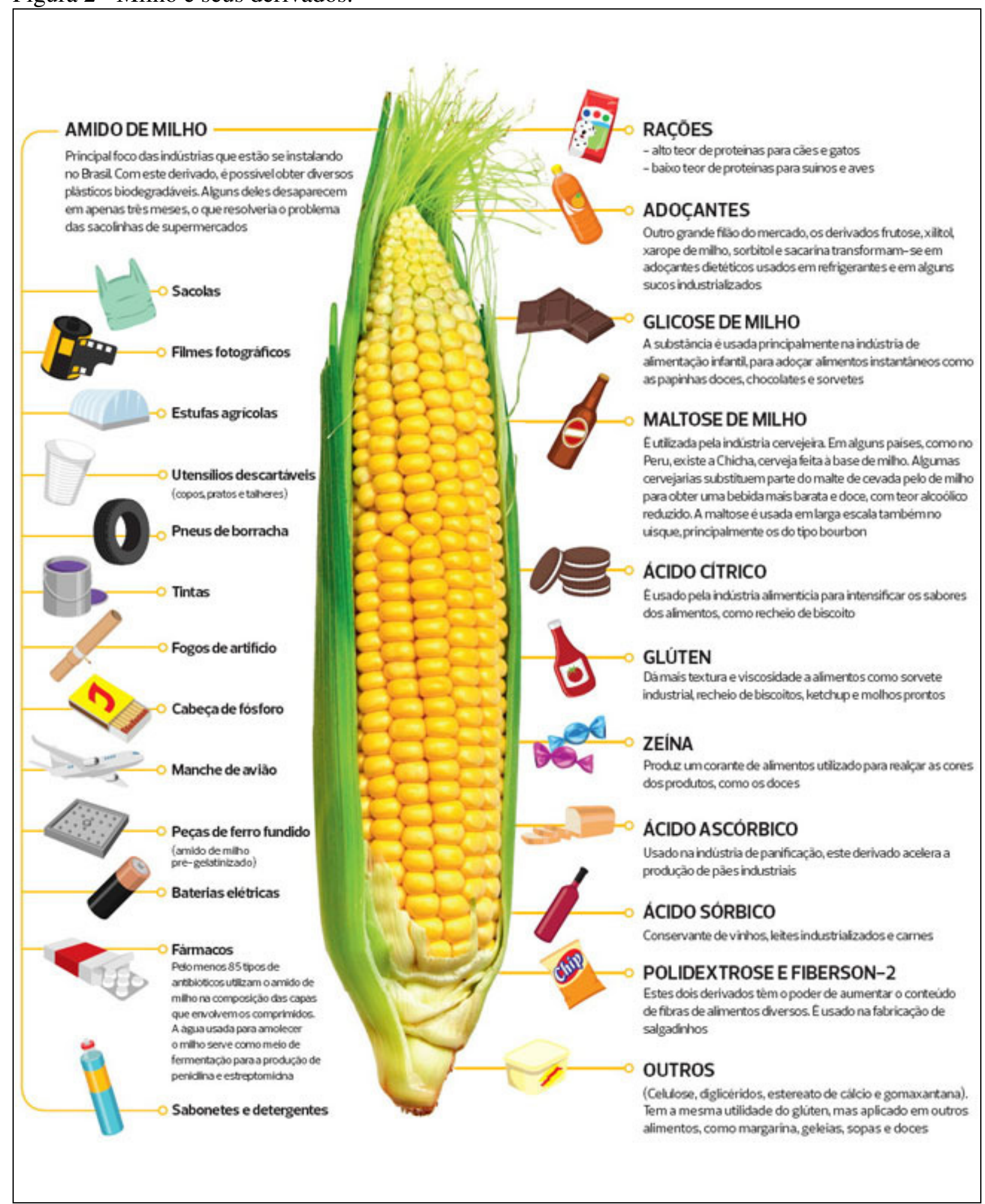

Fonte: Globo Rural, 2012. 
A produtividade do milho depende de vários fatores integrados, sendo os mais importantes a interceptação de radiação pelo dossel, eficiência metabólica, eficiência de translocação de fotossintatos para os grãos e a capacidade de dreno. As respostas diferenciadas dos genótipos à variabilidade ambiental significam que os efeitos genotípicos e ambientais não são independentes. Daí a importância de conhecer a época de plantio analisando todo o ciclo da cultura, procurando prever as condições ambientais em todas as suas fases fenológicas. A produtividade, geralmente, é mais alta quando as condições do tempo permitem o plantio em outubro. Depois disso, há redução no ciclo da cultura e queda no rendimento por área (EMPRESA BRASILEIRA DE PESQUISA AGROPECUÁRIA, 2009).

O milho safrinha não tem um período pré-fixado para seu plantio, como o milho de safra normal, que é plantado no início das chuvas. É uma cultura desenvolvida de janeiro a abril, normalmente após a soja precoce e o milho de verão. Por ser plantada após uma cultura de verão, sua data de plantio depende da época do plantio dessa cultura antecessora e de seu ciclo. Assim, o planejamento do milho safrinha começa com a cultura de verão, visando liberar a área o mais cedo possível. Quanto mais tarde for o plantio, menor será o potencial e maior o risco de perdas por adversidades climáticas (seca e/ou geadas). No Paraná, sul de Mato Grosso do Sul e sudoeste de São Paulo (Vale do Paranapanema), existe elevado risco de geada, principalmente nas áreas acima de $600 \mathrm{~m}$ de altitude. Assim, ao contrário do que é preconizado para o milho de verão, as baixas altitudes são favoráveis ao cultivo da safrinha nas regiões mais ao sul do País. No Paraná, as geadas ocorrem com maior frequência nos meses de junho e julho. Em São Paulo, ocorrem com maior frequência nos meses de junho a agosto (EMBRAPA, 2009).

Deste modo, ressaltamos que a época de semeadura é determinada em função das condições ambientais (temperatura, distribuição das chuvas e disponibilidade de água do solo) e da cultivar (ciclo, fases da cultura e necessidade térmicas das cultivares).

O plantio de milho na época adequada, embora não tenha nenhum efeito no custo de produção, seguramente afeta o rendimento e, consequentemente o lucro do agricultor (EMBRAPA, 2009).

\subsection{Cobertura Morta}

A Cobertura Morta ou mulch foi definida por Stratton e Rechcigl (1998) como sendo materiais orgânicos ou inorgânicos aplicados sobre a superfície do solo. Os autores citam como exemplos de "mulches" inorgânicos o plástico, vidro, vermiculita, rocha, cascalho e 
areia. Já "mulches" orgânicos são definidos como materiais que contém carbono derivado de material vivo, tal como palha, folhas, cavacos de madeira, serragem, alguns tipos de feno e também materiais derivados de compostagem.

É uma prática agrícola que consiste em cobrir a superfície do solo, formando uma camada protetora, atuando na conservação de umidade, exercendo efeito físico sobre as sementes e na população de plantas daninhas, atuando também sobre a passagem de luz e liberando substâncias alelopáticas, desta forma, proporcionando condições adversas para a germinação e o estabelecimento de espécies indesejadas e favoráveis ao desenvolvimento da cultura (EMBRAPA, 2005).

A cobertura morta pode ser formada a partir de culturas, principalmente gramíneas, consorciadas ou não com leguminosas, com alta capacidade de produção de matéria seca, semeadas para este fim na própria área onde se deseja ter a cobertura ou com materiais orgânicos transportados de outros locais, como cascas, sabugos, palhas, serragem entre outros (EMBRAPA, 2005). A presença da cobertura morta proporciona ciclagem de nutrientes, sendo considerado na sustentabilidade dos sistemas agrícolas e otimizando os recursos internos (CHAGAS et al., 2007). Assim, a decomposição de resíduos em solos aumenta a disponibilidade de nutrientes para as culturas subsequentes (REICOSKY; FORCELLA, 1998), propicia maior liberação de nitrogênio e fósforo (MUZILLI, 1981), além de aumentar a disponibilidade de cálcio e magnésio, entre outros nutrientes, nas camadas superficiais do solo (CALEGARI et al., 1992).

$\mathrm{Na}$ cultura do alho, o uso de cobertura morta de solo proporcionou temperaturas mais amenas e teores de umidade mais elevados que o polietileno opaco branco e solo nu (COSTA; SILVA; MELO, 1997). Da mesma forma, na cultura do taro (Colocasia esculenta), verificouse que o uso de materiais derivados de madeira e restos vegetais como cobertura de solo associados à adubação orgânica, foram eficientes na manutenção da umidade, resultando em rizomas com maior peso de matéria fresca e seca (MIYASAKA; HOLLYER; KODANI, 2001).

Resende et al. (2005) avaliaram-se os efeitos de diferentes tipos de cobertura morta de solo de origem vegetal sobre o crescimento, controle de plantas daninhas, produtividade e regime hidrotérmico do solo no cultivo da cenoura, em um experimento conduzido no período de setembro a dezembro de 1998, em Marília - SP. Estudou-se os seguintes tipos de cobertura: serragem de madeira, casca de arroz, maravalha (raspa de madeira), capim seco (Cynodon spp.) e controle (solo sem cobertura morta). A utilização da cobertura morta de solo mostrouse como uma prática vantajosa para o cultivo de verão da cenoura, reduziu a temperatura em 
até $3,5^{\circ} \mathrm{C}$, aumentou a retenção de umidade do solo em até $2,3 \%$ em relação ao controle e melhorou o desenvolvimento das plantas de cenoura. Houve menor incidência de plantas daninhas com o uso de maravalha e capim seco que, juntamente com a serragem, também aumentaram o número de plantas colhidas. Entre os tipos de cobertura morta utilizados, a casca de arroz e a maravalha se destacaram em relação ao solo descoberto como os materiais que proporcionaram maior produtividade (112,6 e 99,6 t/ha respectivamente). O uso de cobertura morta de solo mostrou-se, neste estudo, vantajoso em vários aspectos para cultura da cenoura, sendo técnica e economicamente viável, principalmente, em pequenas áreas e em cultivos orgânicos.

Em pesquisa realizada por Costa, Melo e Ferreira (2007), foi avaliada a eficiência da cobertura morta na retenção de umidade no solo. Os resultados mostraram que o uso de proteção do substrato com folhas secas proporcionou redução significativa na taxa de evaporação da água do solo $(\mathrm{p}<0,01)$.

Uwah e Iwo (2011), analisando a eficácia da cobertura morta orgânica na produtividade do milho e no crescimento de plantas daninhas em Calabar, Nigéria, mostraram que a cobertura orgânica tem o potencial de melhorar o crescimento das culturas e rendimento, bem como o crescimento de ervas daninhas suprimindo proporcionando assim um ambiente conducente para a produção de milho.

Porém, é importante também salientar que a utilização incorreta do mulch pode causar grandes problemas tanto para planta quanto para o solo, tais como dificuldade de aplicação de fertilizantes, aumento ou redução do $\mathrm{pH}$, aumento do teor de oxigênio, excesso de umidade, favorecimento de alguns patógenos, elevação da temperatura do solo e impedimento da emergência de plântulas (GALINDO et al., 1983; HOUSBECK; PENNYPACKER; STEVENSON, 1996; JONES; McCARTER, 1974).

\subsection{Micobiota}

A cultura de milho pode ser afetada por diversos agentes, destacando-se os vírus, bactérias e fungos (CASA; REIS, 2003; PEREIRA, 1997).

Os grãos de milho são substratos suscetíveis à infecção por bolores. Uma grande variedade de fungos está associada ao emboloramento dos grãos, sendo os mais comuns Aspergillus flavus, A. parasiticus, Fusarium graminearum, F. verticillioides, Penicillium spp. e Diplodia maydis (GONZÁLEZ; RESNIK; PACIN, 2003; KPODO; THRANE; HALD, 
2000). Estes fungos produzem diferentes tipos de micotoxinas, metabólitos secundários tóxicos, capazes de acarretar perdas econômicas e danos à saúde humana e animal.

A contaminação pode ocorrer desde o cultivo até a colheita, podendo ocorrer também no transporte, armazenamento e nas diferentes fases de produção, existindo maior intensidade sob condições de temperatura e umidade favoráveis (FRISVAD; SAMSON, 1991).

Após a colheita, o crescimento fúngico depende da ação de muitos fatores como: atividade de água (Aa) da semente, temperatura, umidade, aeração, interação microbiológica, ação de insetos, contaminação interna das sementes, tratamentos químicos e exposição à umidade (HESSELTINE, 1976).

Espécies do gênero Fusarium são importantes contaminantes do milho em todo mundo. Necessitam, para seu crescimento, de um teor de umidade na faixa de $20-21 \%$ e Aa entre 0,80 e 0,90 (CAHAGNIER; MELCION; RICHARD-MOLARD, 1995; LACEY; MAGAN, 1991). As principais espécies associadas a este substrato são $F$. verticillioides, $F$. proliferatum, F. subglutinans (membros do complexo Gibberella fujikuroi) e $F$. graminearum (LESLIE; SUMMERELL, 2006).

As espécies de Fusarium isoladas de ecossistemas naturais ou agrícolas possuem preferências climáticas distintas. Em termos gerais, existem espécies que são cosmopolitas e outras que preferem climas tropicais, quentes, áridos ou ainda temperados (VIGIER et al., 1997). F. verticillioides predomina em regiões tropicais e áreas temperadas úmidas, mas é pouco frequente em zonas temperadas frias. Por sua vez, F. graminearum predomina em regiões de clima tropical a temperado (LESLIE; SUMMERELL, 2006).

Além do gênero Fusarium, outros fungos são também encontrados no milho, como o Aspergillus flavus e o gênero Penicillium (PITT; HOCKING, 2009).

Analisando grãos de milho submetidos à secagem logo após a colheita provenientes de diversos países, Lillehoj e Zuber (1988) verificaram que 92\% das amostras provenientes do Brasil estavam contaminadas com Fusarium spp., 25\% com Penicillium spp. e 8\% com Aspergillus spp.

Em pesquisa realizada por Pereyra et al. (2011) na Argentina com milho moído (matéria-prima) e processado destinados a alimentação de porcos de engorda, verificou-se que todas as amostras analisadas continham pelo menos um dos principais gêneros micotoxigênicos, como Aspergillus, Fusarium e Penicillium. A. flavus e F. verticillioides foram as espécies mais prevalentes.

Mostafa e Kazen (2011), analisando grãos de milho colhidos na Província de Golestan, no Irã, isolaram diversos gêneros fúngicos, entre eles: Fusarium (35.2\%), Aspergillus (2.9\%), 
Penicillium (1.1\%), Rhizopus (2.3\%), Mucor (1.4\%) e Alternaria (0.2\%). Os autores verificaram que, entre as espécies isoladas, $F$. proliferatum e A. flavus foram as mais frequentes.

No Brasil, trabalhos desenvolvidos apontam $F$. verticillioides, considerado endofítico, como o de maior frequência em grãos de milho recém-colhido e armazenado (ALMEIDA et al., 2000; ALMEIDA et al., 2002; ALMEIDA et al., 2005; CORRÊA et al., 1997; HIROOKA et al., 1996; ONO et al., 1999; ORSI et al., 2000; POZZI et al., 1995; ROCHA et al., 2009).

\subsection{Fusarium verticillioides}

F. verticillioides (Sacc.) Nirenberg (sinônimo de F. moniliforme Sheldon) é uma espécie fúngica ubíqua, predominante em regiões tropicais e temperadas. Possui duas fases, uma anamórfica (assexuada), sendo denominado como $F$. verticillioides, e uma teleomórfica (sexuada), conhecida como Gibberella moniliformis (sinônimo de Gibberella fujikuroi) (COVARELLI et al., 2012; LESLIE, 1996; LESLIE; KLEIN, 1996; WOLOSHUK; SHIN, 2001).

Este fungo pode infectar os grãos fazendo uso de três vias: invasão sistêmica, mediante contaminação das sementes, uma vez que é considerado um fungo endofítico; por fissuras na planta já desenvolvida; ou através do "cabelo do milho" (MUNKVOLD; McGEE; CARLTON, 1997). Dentre essas rotas de contaminação, a infecção nos grãos ocorre de forma mais eficiente quando as cepas de F. verticillioides são inoculadas nos "cabelos do milho", proporcionando rompimento da casca e maior severidade no apodrecimento da espiga (WARFIELD; DAVIS, 1996).

A colonização das plantas ou dos grãos por cepas desse fungo pode causar o apodrecimento dos substratos. Perdas causadas por Fusarium spp. variam de 5 a $10 \%$, podendo chegar a 100\% em determinadas áreas (MILLS, 1989). A etiologia do complexo Fusarium-apodrecimento de caule e raiz depende do genótipo do hospedeiro, da espécie do patógeno, das condições ambientais, além de variáveis como tipo de solo, fertilidade, drenagem do solo, práticas culturais, umidade e insetos (FREDERIKSEN, 1996). Soma-se a isso a sua capacidade de produzir fumonisinas, micotoxinas resultantes do metabolismo secundário de, no mínimo, 15 espécies do gênero Fusarium (RHEEDER; MARASAS; VISMER, 2002) e que serão explicadas no próximo item. Outro fator que torna $F$. verticillioides importante do ponto de vista de saúde humana e animal é a sua capacidade de colonizar assintomaticamente a planta ou os grãos. Consequentemente, essa colonização faz 
com que os fungos e suas toxinas sejam processados e consumidos. Entretanto, Munkvold e Desjardins (1997) relataram que a relação entre milho e $F$. verticillioides pode trazer benefícios para a planta, podendo estimular seu crescimento e desenvolvimento, protegendo a planta contra outros agentes patogênicos ou insetos, reduzindo a infecção por Fusarium graminearum e Aspergillus flavus e, diminuindo desta forma, a produção de aflatoxinas. As aflatoxinas produzidas, principalmente, por A. flavus, A. parasiticus e A. nomius, estão entre os mais importantes carcinógenos conhecidos, sendo classificados como classe 1 dos carcinógenos humanos pela International Agency for Research on Cancer (1993).

Segundo Leslie, Zeller e Summerell (2001) existem várias espécies de Fusarium classificadas erroneamente como $F$. verticillioides, o que torna o estudo desse fungo muito difícil. Questões concernentes à natureza e distribuição da variação genética dentro de uma população de patógenos frequentemente coincidem com questões relacionadas a diferenças em nível de espécie. Embora a morfologia fornecesse a única chave para a taxonomia, a biologia molecular integrada às características biológicas transformou-se numa ferramenta essencial para a identificação exata e rápida de espécies de Fusarium (LESLIE; KLEIN, 1996; LESLIE; ZELLER; SUMMERELL, 2001).

Características morfológicas são utilizadas para a identificação inicial de Fusarium (LESLIE; SUMMERELL, 2006). Utilizando critérios morfológicos, Nelson, Touson e Marasas (1983) classificaram as espécies de Fusarium em 16 seções. Na seção Liseola, onde se encontrava $F$. verticillioides, foram incluídos os fungos cuja característica principal era ausência de clamidósporos. Entretanto, $F$. nygamai, produtor de clamidósporo, também foi agrupado na referida seção. A solução foi a sua substituição para o sistema Gibberella fujikuroi, formado por espécies geneticamente distintas com anamorfo Fusarium (LESLIE; SUMMERELL, 2006).

Um dos conceitos biológicos que define o termo "espécie" é a capacidade que os indivíduos (dentro de um grupo) têm de produzirem um novo indivíduo igualmente fértil (FUTUYMA, 1997). No complexo G. fujikuroi, as espécies biológicas são consideradas heterotálicas, ou seja, para a ocorrência de reprodução sexuada entre cepas da mesma espécie há necessidade que cada um dos isolados apresente tipos diferentes de reação sexual ou mating types. O sistema mating types é conduzido pelo loco Mat, composto por um dos dois alelos, denominados Mat-1 e Mat-2 (STEENKAMP et al., 2000). Os isolados podem atuar como fêmeas, machos ou hermafroditas (LESLIE; KLEIN, 1996). F. verticillioides corresponde à população mating "A”, mais frequentemente isolada do milho e capaz de produzir elevados níveis de fumonisinas (LESLIE; SUMMERELL, 2006). 
Para a produção desta micotoxina, Aa mínima que o fungo necessita é de 0,90 (CAHAGNIER; MELCION; RICHARD-MOLARD, 1995). Segundo Woods e Duniway (1986), a Aa ótima e a mínima para crescimento de $F$. verticillioides é de 0,98 e 0,87, respectivamente. Já em relação à temperatura, a máxima se encontra entre $32-37{ }^{\circ} \mathrm{C}$ e a mínima entre $2,5-5^{\circ} \mathrm{C}$, com ótima próxima a $25^{\circ} \mathrm{C}$ (NIRENBERG, 1976).

\subsection{Micotoxinas}

O termo micotoxina é originado da palavra grega "mykes", que significa fungo; e do latim "toxicum", que significa veneno ou toxina (BULLERMAN, 1979; GOLDBLATT, 1972).

Os metabólitos primários dos fungos, e também de outros organismos, são aqueles indispensáveis ao seu crescimento, como carbono, açúcares e lipídios (BU’LOCK, 1980). Já os metabólitos secundários, que caracterizam as quinomas, os pigmentos, os antibióticos e as micotoxinas, são produzidos por diversas espécies de fungos ao final da fase de crescimento exponencial, dependendo do acúmulo dos precursores originados do metabolismo primário, como acetatos, piruvatos e aminoácidos (STEYN, 1977).

O problema das micotoxinas já existia há muito tempo e, provavelmente, vários surtos de micotoxicoses foram confundidos com pragas, envenenamentos, e epilepsia. No Antigo Testamento, as 10 pragas do Egito, quando Moisés tentava libertar os hebreus do domínio faraônico, evidenciaram o problema destes metabólitos. Também há indícios na peste que dizimou os rebanhos e induziu tumores e úlceras nos animais e no povo egípcio (SABINO, 2004). Em 1850, ocorreu o episódio chamado de "Fogo de Santo Antônio", no qual a ingestão de centeio infectado por Claviceps purpurea foi relacionada com características do ergotismo, levantando a possibilidade do perigo de metabólitos tóxicos produzidos por fungos (SANTURIO, 2000). No Japão, muitas mortes foram associadas a ingestão de arroz contaminado por Penicillium spp. (SAITO et al., 1971); e na Rússia, por Fusarium sporotrichioides, que causou ulcerações necróticas nos lábios e mucosa oral da população (CAMPBELL; STOLOFF, 1974).

A produção de micotoxinas pelos fungos depende de uma série de fatores, incluindo a susceptibilidade do substrato à colonização do fungo produtor; fatores físicos como temperatura do ambiente, umidade do substrato, umidade relativa do ar durante o armazenamento, aeração, danos mecânicos e tempo de armazenamento e fatores biológicos como capacidade genética do fungo em produzir micotoxinas, quantidade de esporos viáveis, 
interação de diferentes fungos existentes no mesmo substrato, interação de micotoxinas e presença de insetos (CIEGLER, 1978).

Estas micotoxinas mantêm sua atividade biológica por um longo período, podendo causar as micotoxicoses (JAY, 1994); quando associadas aos alimentos e ração animal, são ingeridas, causando graves efeitos sobre a saúde (SANTURIO, 2000), acarretando efeitos tóxicos agudos ou crônicos, dependendo do sistema teste, dosagem e frequência da exposição (JAY, 1994). Segundo Miller (1994), a exposição crônica às micotoxinas através da dieta, ou seja, a ingestão de pequenas doses por um longo período acarreta efeitos mais significativos que a exposição aguda, sendo diretos e substanciais na saúde humana.

Existem centenas de micotoxinas detectadas produzidas por pelo menos 350 espécies de fungos (SABINO, 2004), porém as mais estudadas e comumente encontradas em alimentos são: aflatoxinas e ácido ciclopiazônico, produzidas principalmente, por Aspergillus spp.; fusariotoxinas, representadas pela zearalenona, fumonisinas, moniliforminas e tricotecenos, produzidas por Fusarium spp.; e ocratoxinas, produzidas por Aspergillus alutaceus (A. ochraceus) e várias espécies do gênero Penicillium (CLEVSTROM, 1986).

De acordo com Taniwaki e Silva (2001), as micotoxinas muitas vezes ocorrem em baixas concentrações, o que dificulta sua detecção. Além disso, uma mesma toxina pode ser produzida por uma variedade de fungos, porém, nem todos os fungos são produtores de micotoxinas. Dentro de uma mesma espécie, existem cepas produtoras e outras não produtoras de micotoxinas (ROSSETTO; SILVA; ARAUJO, 2005). A ausência de sinais visíveis do crescimento fúngico não pode ser totalmente interpretada como ausência de toxinas, já que estas são capazes de permanecer em um alimento, mesmo depois que o fungo produtor tenha sido eliminado (TANIWAKI; SILVA, 2001).

\subsection{Fumonisinas}

As fumonisinas são metabólitos secundários, descobertos na África do Sul em 1988, produzidos principalmente por $F$. verticillioides (Sacc.) Nirenberg ( $=F$. miniliforme Sheldon), F. proliferatum (Matsushima) Nirenberg, F. oxysporum Schlecht e F. globosum Rheeder, Marasas, et Nelson (GELDERBLOM et al., 1988; SCOTT, 1993; SCOTT, 2012).

Além dessas espécies, existem várias outras espécies do gênero produtoras de micotoxinas, tais como: F. anthophilum (A. Braun) Wollenw., F. dlamini Marasas, Nelson, et Toussoun, F. napiforme Marasas, Nelson, et Rabie, F. nygamai Burgess et Trimboli, $F$. thapsinum Klittich, Leslie, Nelson, et Marasas, F. sacchari (Butler) W. Gams, F. fujikuroi 
Nirenberg, F. subglutians (Wollenw et Reinking) Nelson, Toussoun, et Marasas, $F$. subglutians sensu lato, F. pseudonygamai (Nirenberg, O'Donnell), F. andiyazi Marasas et al. e F. polyphialidicum Marasas, P.E. Nelson, Toussoun \& P.S. van Wyk (MARÍN et al., 2004; RHEEDER; MARASAS; VISMER, 2002). Recentemente, descobriu-se que Aspergillus niger isolados de uvas, uvas passas e grãos de café produziram $\mathrm{FB}_{2}$ e $\mathrm{FB}_{4}$, porém, apresentam regulação da produção e perfil quantitativo das fumonisinas diferentes de $F$. verticillioides (KNUDSEN et al., 2011; LOGRIECO et al., 2009; MOGENSEN et al., 2010; NOONIM et al., 2009; SCOTT, 2012). Sabe-se também que compostos semelhantes às fumonisinas são produzidos por Alternaria alternata f. sp. lycopersici (BOTTINI; GILCHRIST, 1981; SCOTT, 2012).

As fumonisinas são frequentemente encontradas em milho e alimentos a base de milho (SHEPHARD et al., 1996; WEIDENBORNER, 2001). São compostos polares e solúveis em água e acetonitrila-água, mas não são solúveis em solventes orgânicos (WASKIEWICZ; BESZTERDA; GOLINSKI, 2012).

Das quatro fumonisinas da série $\mathrm{B}\left(\mathrm{FB}_{1}, \mathrm{FB}_{2}, \mathrm{FB}_{3}\right.$ e $\left.\mathrm{FB}_{4}\right)$, dentre outras séries análogas (RHEEDER; MARASAS; VISMER, 2002) (Figura 3), a fumonisina $\mathrm{B}_{1}\left(\mathrm{FB}_{1}\right)$ é a principal delas, sendo considerada a mais tóxica e a mais frequente na natureza (NELSON et al., 1991; SYDENHAM et al., 1991; SCOTT, 2012). A FB 1 está presente não apenas no milho e em seus subprodutos, mas também em cerveja, arroz, sorgo, feijão-de-corda, feijões, soja e aspargos (SCOTT, 2012). Ela pode ocasionar leucoencefalomalácia em equinos (LEME), edema pulmonar em suínos, câncer hepático em ratos, redução do desenvolvimento, imunossupressão, problemas cardíacos, degeneração e necrose hepática em aves, além de estar associada ao câncer esofágico em humanos e alterações no tubo neural (NTD) (MARASAS, 1996; MARASAS, 2001; MISSMER et al., 2006; NORRED; VOS, 1994; STACK, 1998).

Nos últimos anos, as fumonisinas vêm sendo encontradas em uma ampla variedade de alimentos, além dos que já foram mencionados anteriormente: mandioca na Tanzânia (MANJULA et al., 2009), alho e cebola em pó (BOONZAAIJER et al., 2008) e bulbos de alho (SEEFELDER; GOSSMANN; HUMPF, 2002), rabanete preto (DI MAVUNGU et al., 2009), chá preto (MARTINS; MARTINS; BERNARDO, 2001; OMURTAG; YAZICIOGLU, 2004), figos na Turquia (KARBANCIOGLU-GULER; HEPERKAN, 2009; SENYUVA; GILBERT, 2008), amendoins na Costa do Marfim, Camarões e China (LIU, Q.; LIU, G.; LIU, H., 2008; NJOBEH et al., 2010; SANGARE-TIGORI et al., 2006) e soja no Japão (AOYAMA et al., 2010). Utilizando uma metodologia mais sensível (LC-MS/MS), $\mathrm{FB}_{1}$ foi recentemente detectada em $80 \%$ das amostras de leite de vaca comerciais na Itália (GAZZOTTI et al., 2009). 
Na África do Sul, Portugal, Turquia e Espanha, fumonisinas foram encontradas em plantas silvestres alimentares e medicinais (MARTINS; MARTINS; BERNARDO, 2001; OMURTAG; YAZICIOGLU, 2004; SANTOS et al., 2009; SEWRAM et al., 2006). Vale ressaltar que, para alguns alimentos, a $\mathrm{FB}_{1}$ não é a principal fumonisina encontrada, como no milho e em outros grãos. Uma preocupação atual é a ocorrência de $\mathrm{FB}_{2}$ ( $\operatorname{sem} \mathrm{FB}_{1}$ ) no vinho de vários países (LOGRIECO et al., 2010; MOGENSEN; LARSEN; NIELSEN, 2010). FB $_{2}$ foi detectada também em cerveja (ROMERO-GONZÁLEZ et al., 2009) e, junto com $\mathrm{FB}_{4}$, em café (NOONIM et al., 2009).

Figura 3 - Estrutura química das fumonisinas.

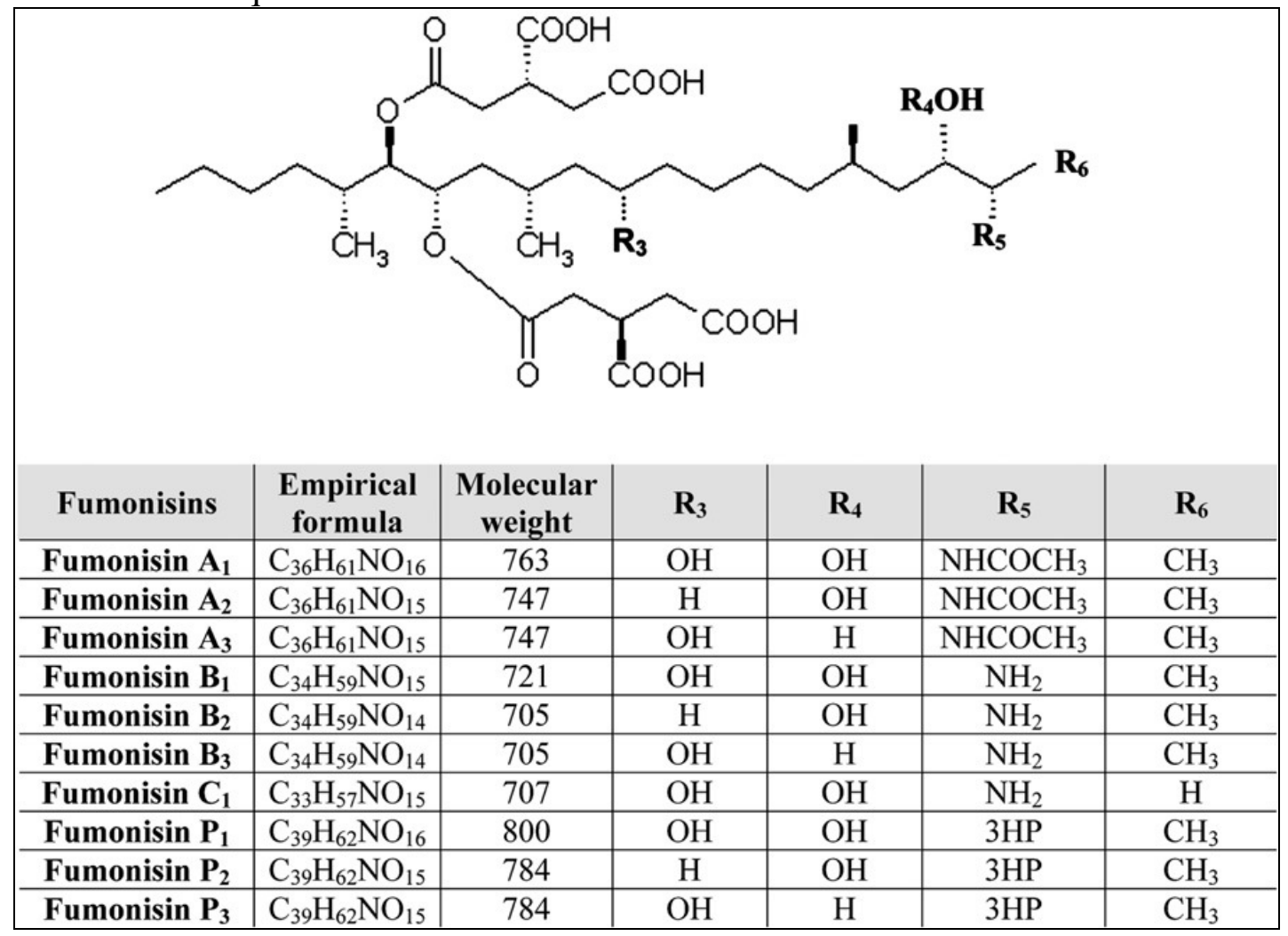

Fonte: Waskiewicz, Beszterda e Golinski, 2012.

O mecanismo de ação das fumonisinas em células de mamíferos está relacionado com a inibição do metabolismo dos esfingolípideos (Figura 4). Os esfingolipídeos, presentes nas membranas celulares, desempenham um papel fundamental na regulação celular e no controle de proteínas membranares, mediando o crescimento, a diferenciação e a morte das células (LINO; SILVA; PENA, 2004; TURNER; NIKIEMA; WILD, 1999). Os esfingolipídeos mais simples são as bases esfingóides. Nas células dos mamíferos, as bases esfingóides mais comuns são as esfingosina e a esfinganina. Normalmente, a concentração de esfingosina é 3 a 
5 vezes mais elevada que a esfinganina (LINO; SILVA; PENA, 2004; RILEY; WANG; MERRIL, 1994). Em estudos in vivo e in vitro foi demonstrado que as fumonisinas, com exceção da serie A, são potentes inibidores competitivos da esfinganina $\mathrm{N}$-aciltransferase e da esfingosina $\mathrm{N}$-aciltransferase (ceramida sintetase), uma vez que, estruturalmente, são análogas de bases esfingóides. As enzimas anteriormente referidas são elementos chave para a via metabólica da biossíntese dos esfingolipídeos (LINO; SILVA; PENA, 2004;).

Figura 4 - Mecanismo de ação das fumonisinas.

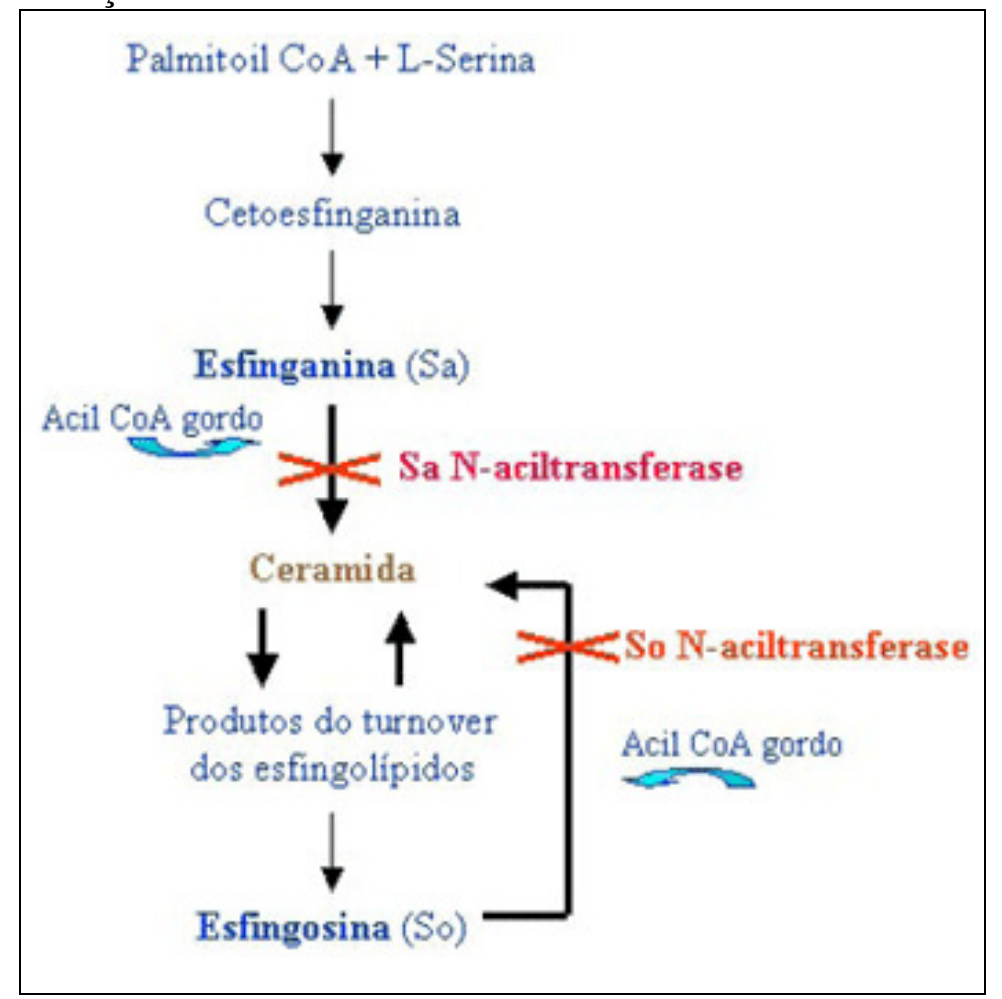

Fonte: Lino, Silva e Pena, 2004.

Deste modo, as fumonisinas podem alterar a concentração e a proporção entre a esfinganina e a esfingosina, diminuindo a biossíntese de esfingosina e acumulando esfinganina (CARRATÙ et al., 2003; DESAI et al., 2002; LINO; SILVA; PENA, 2004; RILEY; WANG; MERRIL, 1994; TURNER; NIKIEMA; WILD, 1999) (Figura 4). Podem também bloquear a biossíntese de esfingolipídeos complexos em células eucarióticas. Os esfingolipídeos complexos desempenham funções muito importantes na biogênese das membranas celulares, estando também na base da formação de segundos mensageiros que controlam diferentes processos celulares, incluindo expressão gênica e ativação/desativação de proteínas (RILEY; WANG; MERRIL, 1994). Como consequência dos efeitos detrimentais em células eucarióticas causados pelas micotoxinas, estão a indução de apoptose e efeitos 
carcinogênicos (DESAI et al., 2002; LINO; SILVA; PENA, 2004; TURNER; NIKIEMA; WILD, 1999).

As fumonisinas são consideradas como possivelmente carcinogênicas para seres humanos (IARC, 1993).

A frequente ocorrência de fumonisinas no milho como também suas implicações, tem incentivado o desenvolvimento de diversas técnicas de separação destas micotoxinas, destacando-se a cromatografia líquida de alta eficiência (CLAE) com detector de fluorescência, apresentando, como vantagens, alta resolução, menor tempo de análise, alta sensibilidade e versatilidade (DILKIN et al., 2001). Muscarella et al. (2008) também relatam e indicam o uso de CLAE com detector de fluorescência para análise de $\mathrm{FB}_{1}$ e $\mathrm{FB}_{2}$ em milho e seus subprodutos, com derivatização pós coluna utilizando OPA (ortoftaldeído) e NN-dimetil2-mercaptoetilamina. O uso de colunas de imunoafinidade para extração e limpeza, tem possibilitado maior especificidade permitindo limites de detecção mais baixos e uso de menor volume de solventes (SHUNDO, 2004).

Até o presente momento não há uma legislação global para regular os níveis máximos permitidos de fumonisinas no milho e em produtos processados a partir do mesmo. Entretanto, mais de 90 países apresentam regulamentação própria ou níveis máximos tolerados para algumas micotoxinas, dependendo do tipo de matriz (LINO; SILVA; PENA, 2004).

$\mathrm{Na}$ Suíça foi estabelecido um limite máximo de $1,0 \mathrm{mg} / \mathrm{kg}$ para a somatória de $\mathrm{FB}_{1} \mathrm{e}$ $\mathrm{FB}_{2}$ em milho para consumo humano (LINO; SILVA; PENA, 2004; SHEPHARD et al., 2000) e, em 1997, o "Swiss Federal Office of Public Health" estabeleceu um valor de tolerância de $1,0 \mu \mathrm{g} / \mathrm{kg}$ para $\mathrm{FB}_{1}+\mathrm{FB}_{2}$ em produtos processados a partir do milho seco (CIRILLO et al., 2003; LINO; SILVA; PENA, 2004; SORIANO; DRAGACCI, 2004). O "French Council of Public Hygiene" recomendou um valor máximo de 3,0 mg/kg para $\mathrm{FB}_{1}+\mathrm{FB}_{2}$ em cereais (LINO; SILVA; PENA, 2004). A United States - Food and Drug Administration (US-FDA CFSAN), em 2001, aconselhou níveis máximos de 2-4 mg/kg para total de $\mathrm{FB}_{1}, \mathrm{FB}_{2}$ e $\mathrm{FB}_{3}$ em produtos de milho utilizados para alimentação humana e $3 \mathrm{mg} / \mathrm{kg}$ para milho de pipoca, que foram também considerados na Itália como limites de referência (CIRILLO et al., 2003; LINO; SILVA; PENA, 2004). A Eslováquia estabeleceu limite no milho, o qual não deve exceder 100-200 $\mu \mathrm{g} / \mathrm{kg}$ (LABUDA; TANCINOVA; HUDEC, 2003; LINO; SILVA; PENA, 2004). A US-FDA recomenda níveis máximos de fumonisinas de 1, 10, 30, 50 e $15 \mathrm{mg} / \mathrm{kg}$ na ração total de cavalos, suínos, ruminantes, aves e vacas leiteiras, respectivamente. US-FDA considera que os níveis recomendados para as fumonisinas no milho e derivados para consumo humano são uma medida prudente para a Saúde Pública (LINO; SILVA; PENA, 2004). 
Atualmente as legislações portuguesa e canadense não possuem limites para os níveis de fumonisinas em alimentos destinados a humanos e animais (SCOTT, 2012).

Segundo Scott (2012), a Comissão Europeia recomendou, em 2007, limites máximos de $4.000 \mu \mathrm{g} / \mathrm{kg}$ para fumonisinas totais $\left(\mathrm{FB}_{1}+\mathrm{FB}_{2}\right)$ em milho não processado, $1.000 \mu \mathrm{g} / \mathrm{kg} \mathrm{em}$ milho e alimentos à base de milho destinados a consumo humano direto, $800 \mu \mathrm{g} / \mathrm{kg}$ em cereais matinais e snacks à base de milho e $200 \mu \mathrm{g} / \mathrm{kg}$ em alimentos à base de milho para bebês e crianças.

O relatório do "Council for Agricultural Science and Technology" estabelece que um dos objetivos para este século é o estabelecimento de uma legislação uniforme, mundial, para a contaminação dos alimentos por micotoxinas (LINO; SILVA; PENA, 2004; WU, 2004).

No Brasil, em 2011, estipulou-se a recomendação para limites máximos tolerados de $\mathrm{FB}_{1}+\mathrm{FB}_{2}$ para milho de pipoca $(2000 \mu \mathrm{g} / \mathrm{kg})$ e alimentos a base de milho para alimentação infantil $(200 \mu \mathrm{g} / \mathrm{kg})$. A partir de 2012, outros alimentos foram adicionados à resolução, como farinha de milho, creme de milho, fubá, flocos, canjica e canjiquinha, cujo limite máximo tolerado é de $2500 \mu \mathrm{g} / \mathrm{kg}$. Também foram adicionados amido de milho e outros produtos a base de milho, cujo limite máximo tolerado é de $2000 \mu \mathrm{g} / \mathrm{kg}$ (BRASIL, 2011).

Já está publicado no Diário Oficial da União de 22 de fevereiro de 2011 (Resolução $\mathrm{RDC} \mathrm{N}^{\mathrm{o}}$ - 7) que a partir de janeiro de 2014, o limite máximo preconizado para $\mathrm{FB}_{1}+\mathrm{FB}_{2} \mathrm{em}$ milho em grão para posterior processamento será de $5000 \mu \mathrm{g} / \mathrm{kg}$. Nessa mesma resolução, consta que, será aplicado a partir de janeiro de 2016, o limite máximo tolerado para $\mathrm{FB}_{1}+\mathrm{FB}_{2}$ em farinha de milho, creme de milho, fubá, flocos, canjica, canjiquinha de $1500 \mu \mathrm{g} / \mathrm{kg}$ e em amido de milho e outros produtos a base de milho de $1000 \mu \mathrm{g} / \mathrm{kg}$ (BRASIL, 2011).

\subsection{Métodos para Controle das Doenças Fúngicas}

\subsubsection{Rotação de Culturas}

Os primeiros métodos utilizados para controle das doenças fúngicas são rotação de cultura, plantas resistentes e o uso de fungicidas químicos (ABAWI; WIDMER, 2000).

A rotação de culturas consiste no cultivo alternado de espécies vegetais numa mesma área agrícola e na mesma estação de cultivo. Ela tem como benefícios a promoção da biodiversidade, o favorecimento ao manejo integrado de pragas, de doenças e de plantas infestantes, a redução do inóculo inicial de muitos patógenos hemibiotróficos, a promoção de cobertura permanente do solo, a diversificação e estabilização da produtividade, a 
racionalização de mão-de-obra, e a redução do risco de perdas de renda (EMBRAPA, 2010; FANTIN et al., 2012).

Embora seja pequeno o efeito no controle da erosão, a rotação de culturas assume importância como prática adicional para a manutenção da capacidade de produção dos solos. A monocultura contínua tende a provocar, com o passar dos anos, sensível queda de produtividade, não só por alterar características do solo, como também por proporcionar condições favoráveis ao desenvolvimento de doenças e à ocorrência de pragas e de plantas invasoras. Assim, a prática da rotação de culturas visa também reduzir o potencial de inóculo de organismos causadores de podridões radiculares e de manchas foliares (EMBRAPA, 2010).

A rotação de culturas, embora seja uma medida importante no manejo integrado das doenças, sobretudo no sistema de plantio direto, muitas vezes apresenta dificuldade em ser implantada pelo agricultor, que opta por uma determinada cultura em função da previsão das melhores oportunidades de comercialização do produto final. Há mais de uma década, na maioria das regiões produtoras do milho safrinha, predomina o cultivo contínuo de soja no verão e milho safrinha no outono-inverno, sendo o milho a única cultura utilizada no verão para sucessão com a soja, entretanto, pode ocorrer também a semeadura do milho no verão antecedido ou seguido de milho safrinha (FANTIN et al., 2012).

Reis, Casa e Bresolin (2004) ressaltaram que a eficácia da rotação de culturas, usada integradamente com outras medidas de controle, tem sido demonstrada para outros cultivos como, por exemplo, os cereais de inverno, porém, alertam que a sua potencialidade de uso ainda não foi devidamente quantificada em culturas de milho no Brasil.

O impacto da rotação de culturas de longo prazo sobre as populações de fitopatógenos do gênero Fusarium, Pythium e Rhizoctonia e no desenvolvimento de plântulas de canola foi avaliado sob condições controladas por Hwang et al. (2009), no Canadá. Os autores sugeriram que culturas diversificadas na rotação podem reduzir as populações de Fusarium spp., Pythium spp. e Rhizoctonia spp. no solo além de contribuir no desenvolvimento da canola.

\subsubsection{Milho Bt}

O milho Bt é um milho geneticamente modificado, que expressa o gene Bt, clonado da bactéria Bacillus thuringiensis (CARNEIRO et al., 2009).

B. thuringiensis é uma bactéria gram-positiva que produz $\alpha$-exotoxinas, $\beta$-exotoxinas e $\delta$-endotoxinas, todas com ação tóxica para uma ampla variedade de insetos que degradam a cultura do milho. Os genes codificadores para a $\delta$-endotoxinas (proteínas “Cry”), clonados de 
algumas estirpes de $B$. thuringiensis, têm sido utilizados por várias empresas nos EUA para a obtenção dessas sementes mais resistentes (BOULDER, 1993; WAQUIL et al., 2002).

Segundo pesquisas realizadas por Castro (2008), são atribuídas diversas vantagens às variedades de milho $\mathrm{Bt}$, entre elas: necessidade de menor quantidade de inseticidas, oferecimento de menor risco de contaminação do lençol freático e dos rios, além de um menor consumo de água, gerarem maior produtividade e maior rentabilidade. Este grão é considerado seguro em relação aos mamíferos. Outra vantagem para a sua utilização é a especificidade em relação aos insetos-praga das diferentes culturas, não afetando, por exemplo, os insetos que utilizam o milho como hospedeiro (CARNEIRO et al., 2009).

Existem duas metodologias diferentes para a inserção do gene $\mathrm{Bt}$ (genes codificadores para a $\delta$-endotoxinas) no genoma do milho: transformação genética indireta e direta (CARNEIRO et al., 2009).

A metodologia direta envolve o bombardeamento de células vivas com o DNA de interesse. Na transformação via bombardeamento de partículas ou biobalística, micropartículas de metal (tungstênio ou ouro), cobertas com o gene de interesse, são aceleradas em direção às células-alvo (através de faísca de alta tensão elétrica ou uma descarga de hélio) utilizando equipamentos conhecidos como "gen-gun" ou canhão genético (SANFORD et al., 1987). O DNA precipitado sobre as micropartículas é liberado gradualmente dentro da célula pós-bombardeamento e integrado no genoma (TAYLOR; FAUQUET, 2002; CARNEIRO et al., 2009). As principais vantagens do bombardeamento estão relacionadas com a utilização de vetores simples e de fácil manipulação, além da possibilidade de inserção de mais de um gene de interesse nas células de maneira eficiente (WU et al., 2002).

A metodologia indireta é através da transformação via bactéria Agrobacterium tumefaciens. Essa bactéria possui o plasmídeo Ti, que pode se replicar independentemente do genoma da bactéria (CARNEIRO et al., 2009; GELVIN, 2003).

O mecanismo de ação das proteínas Cry de Bt envolvem a solubilização do cristal no intestino médio do inseto, a ação de proteases sobre a protoxina, a aderência da toxina Cry aos receptores do intestino médio e a sua inserção dentro da membrana apical criando canais de íons ou poros. A degradação dos cristais proteicos por enzimas proteolíticas libera proteínas tóxicas menores, chamadas de $\delta$-endotoxinas. A atividade das $\delta$-endotoxinas está restrita ao trato digestivo dos insetos. Após a solubilização, muitas protoxinas devem ser processadas por proteases presentes no intestino médio do inseto para se tornarem toxinas ativas. As 
proteínas Cry ativadas funcionam junto a receptores e canais iônicos do intestino (TOJO; AIZAWA, 1983; CARNEIRO et al., 2009) (Figura 5).

Figura 5 - Esquema da inserção do gene cry no genoma do milho e a ação das toxinas Bt no intestino médio de insetos suscetíveis.

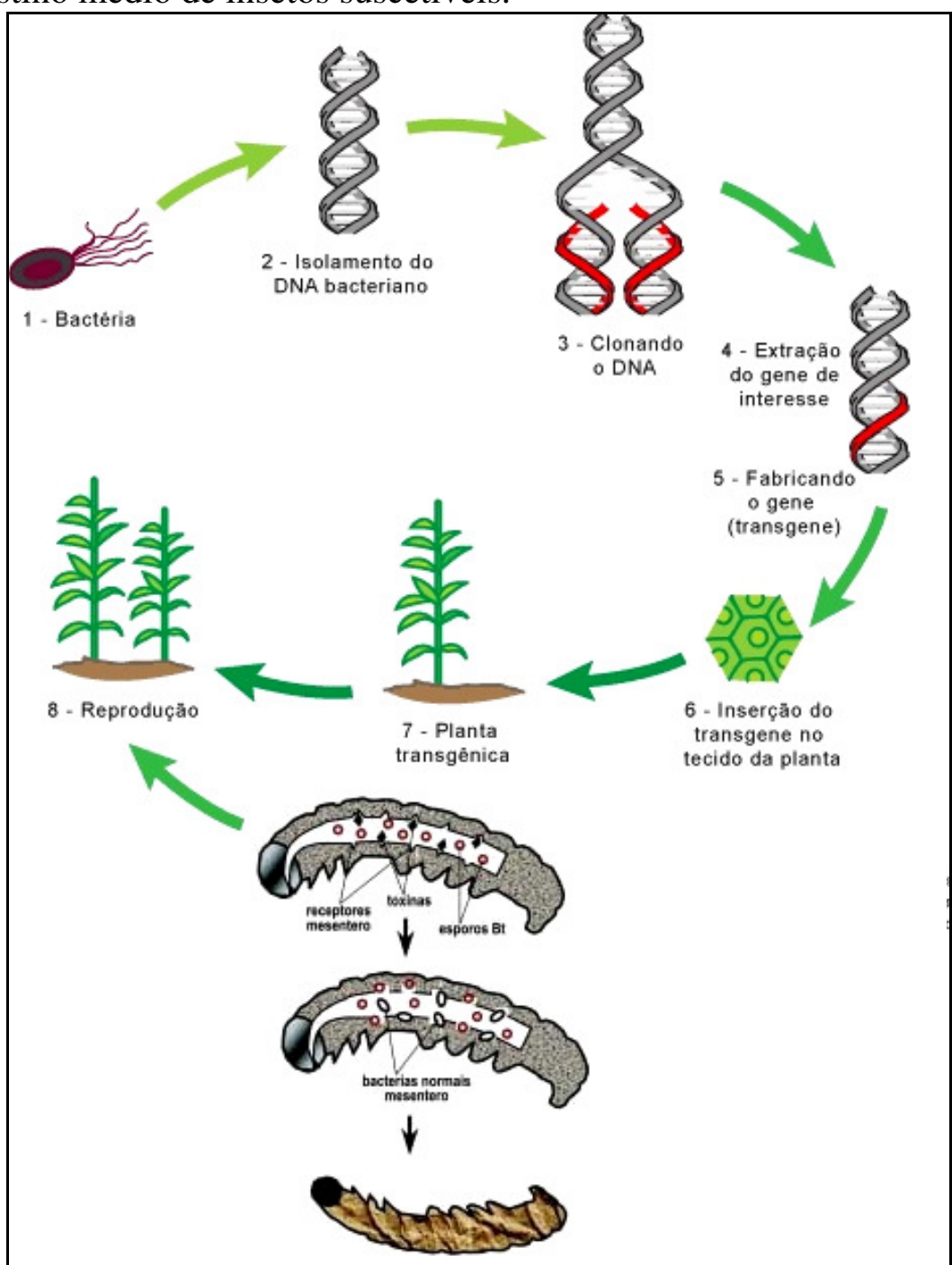

Fonte: Loguercio, Carneiro e Carneiro, 2002.

O primeiro milho $\mathrm{Bt}$ utilizado comercialmente ocorreu no ano de 1996 com a produção do milho Maximizer ${ }^{\mathrm{TM}}$, pela empresa Novartis no mercado Norte Americano (JOUANIN et al., 1998).

As primeiras pesquisas brasileiras com milho transgênico começaram em 1997, no caso, com o milho Bt11 (SYNGENTA, 2010). Híbridos de milho trangenico expressando a proteína Cry1Ab foram liberados comercialmente em 2007 (MON810 ou MilhoGuardian) (COMISSÃO TÉCNICA NACIONAL DE BIOSSEGURANÇA, 2008). 
Em 2010, foram plantados cerca de 19 milhões de hectares de milho transgênico em 16 países (JAMES, 2010). O Brasil assumiu a posição de terceiro maior produtor de transgênicos, responsável por $12 \%$ da área total com transgênicos no mundo, superado pela Argentina e EUA (JAMES, 2007). A área estimada semeada com milhos transgênicos, em 2010/11, no Brasil, foi de 7,37 milhões de hectares ou 57,2\% da área total, destacando-se um incremento do milho transgênico na safrinha (MENEZES et al., 2011).

Dentre alguns genótipos de milho que expressam as toxinas "Cry", podemos destacar os que expressam Cry1F, Cry1 Ab e os que expressam ambas as toxinas. Alguns estudos têm demonstrado a diminuição na produção de fumonisinas por $F$. verticillioides em milhos $B t$, como os trabalhos de Munkvold, Hellmich e Rice (1999) e Papst et al. (2005) e como citado por Duvick (2001). Hammond et al. (2004) verificaram diminuição nos níveis de fumonisinas em híbridos de milho $B t$ contendo a proteína Cry $1 \mathrm{Ab}$ durante o desenvolvimento da cultura em condições naturais e com infestação forçada pelos insetos Ostrinia nubilalis (broca européia do milho) e Diatraea grandiosella (broca do milho do sudoeste). Estes autores atribuem a diminuição na produção de fumonisinas pela queda da infestação dos insetos nos grãos e, consequentemente, manutenção da integridade dos mesmos, dificultando a entrada de fungos toxigênicos, como, por exemplo, Fusarium spp.

Com a utilização de sementes de milho geneticamente modificadas foi possível a obtenção de genótipos mais resistentes às principais pragas que degradam a cultura do milho, como a Spodoptera frugiperda (lagarta-do-cartucho) e a Helicoverpa zea (lagarta-da-espiga) (CARNEIRO et al., 2009). O milho Bt permite reduzir o ataque de insetos em até 90\%, diminuindo, consequentemente, a probabilidade de crescimento de fungos através das perfurações provocadas pelos insetos-pragas (MARQUES, 2009), que levam a prejuízos econômicos e danos à saúde humana e animal.

A presença de $F$. verticillioides nos grãos de milho representa um sério problema nacional, pois as contaminações pelas toxinas produzidas por este fungo causam prejuízos à economia e, principalmente, riscos à saúde humana e animal. Desta forma, tornam-se necessárias pesquisas minuciosas nesta área, incluindo a utilização de sementes geneticamente modificadas mais resistentes e a rotação de culturas como métodos para controle das doenças, além da determinação de meios rápidos e eficazes na detecção destes micro-organismos, como também a adoção de boas práticas de cultivo para a diminuição dos riscos de contaminação dos alimentos. 


\section{PROPOSIÇÃO E OBJETIVOS}

Uma das causas da baixa produtividade e da baixa qualidade dos grãos está relacionada à ocorrência de doenças causadas por fungos patogênicos, aliada às condições climáticas e às práticas culturais. Entre as medidas de controle utilizadas, práticas simples, como rotação de culturas e manejo adequado da população de plantas, podem ser consideradas opções econômicas e eficientes para minimizar danos.

O efeito de diferentes culturas tende a refletir na composição química da colheita, estrutura da raiz e habilidade para alterar as propriedades químicas e biológicas do solo. Porém, doenças são também prevalentes quando culturas susceptíveis são usadas em uma sequência que permite a formação de uma alta densidade populacional de patógenos de plantas provenientes do solo. Provavelmente, a disponibilidade do inóculo de fungos como $F$. verticillioides seja maior no sistema monocultura, uma vez que esses fungos sobrevivem saprofiticamente nos restos culturais. Reid, Zhu e Ma (2001) consideram F. verticillioides onipresente na natureza, contudo, nem sempre patogênico. Entretanto, Munkvold, Hellmich e Showers (1997) relataram a possibilidade de infecção sistêmica a partir do inóculo da semente ou do solo, resultando na infecção das espigas e dos grãos.

Do ponto de vista dessa problemática, a identificação de Fusarium spp., presentes nas amostras de milho e de cobertura morta, por meio de metodologia clássica e molecular, poderá contribuir para o conhecimento mais acurado da população deste fitopatógeno em sistema de rotação de cultura em regiões produtoras com diferentes altitudes.

Diante do exposto, da importância e atualidades dos estudos sobre fumonisinas, o presente trabalho possui objetivo geral avaliar a influência da rotação de cultura no crescimento fúngico e na ocorrência de fumonisinas em grãos de milho em regiões produtoras no Estado de São Paulo, Palmital e Capao Bonito.

Visam-se como objetivos específicos:

- Identificar a micobiota presente na cobertura morta e nos grãos de milho transgênico $\mathrm{Bt}$;

- Correlacionar a micobiota dos grãos e da cobertura morta com os níveis de Aa das amostras;

- Determinar a presença de fumonisinas $\left(\mathrm{FB}_{1}\right.$ e $\left.\mathrm{FB}_{2}\right)$ nas amostras de grãos de milho;

- Identificar as espécies do gênero Fusarium isoladas da cobertura morta e dos grãos utilizando metodologia clássica (macro e micromorfologia) e molecular (sequenciamento parcial do gene TEF-1 $\alpha$ ); 
- Estudar o potencial toxigênico quanto à produção de $\mathrm{FB}_{1}$ e $\mathrm{FB}_{2}$ dos isolados de $F$. verticillioides;

- Correlacionar os resultados obtidos de ambas as regiões e de todos os tratamentos com os fatores climatológicos. 


\section{MATERIAIS E MÉTODOS}

\subsection{Caracterizaçoes das Unidades Experimentais}

Os experimentos foram conduzidos em duas localidades no Estado de São Paulo:

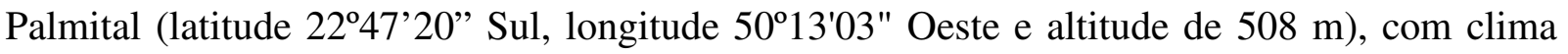
quente, inverno seco e Latossolo vermelho distroférrico; e Capão Bonito (latitude 2400'21" Sul, longitude 48²0'58' Oeste, e altitude de 705 m), região localizada na zona fisiográfica do Paranapiacaba, de clima temperado e Latossolo vermelho escuro distrófico (Figura 6).

Figura 6 - Mapa do Estado de São Paulo, identificando os municípios onde foram realizados os experimentos.

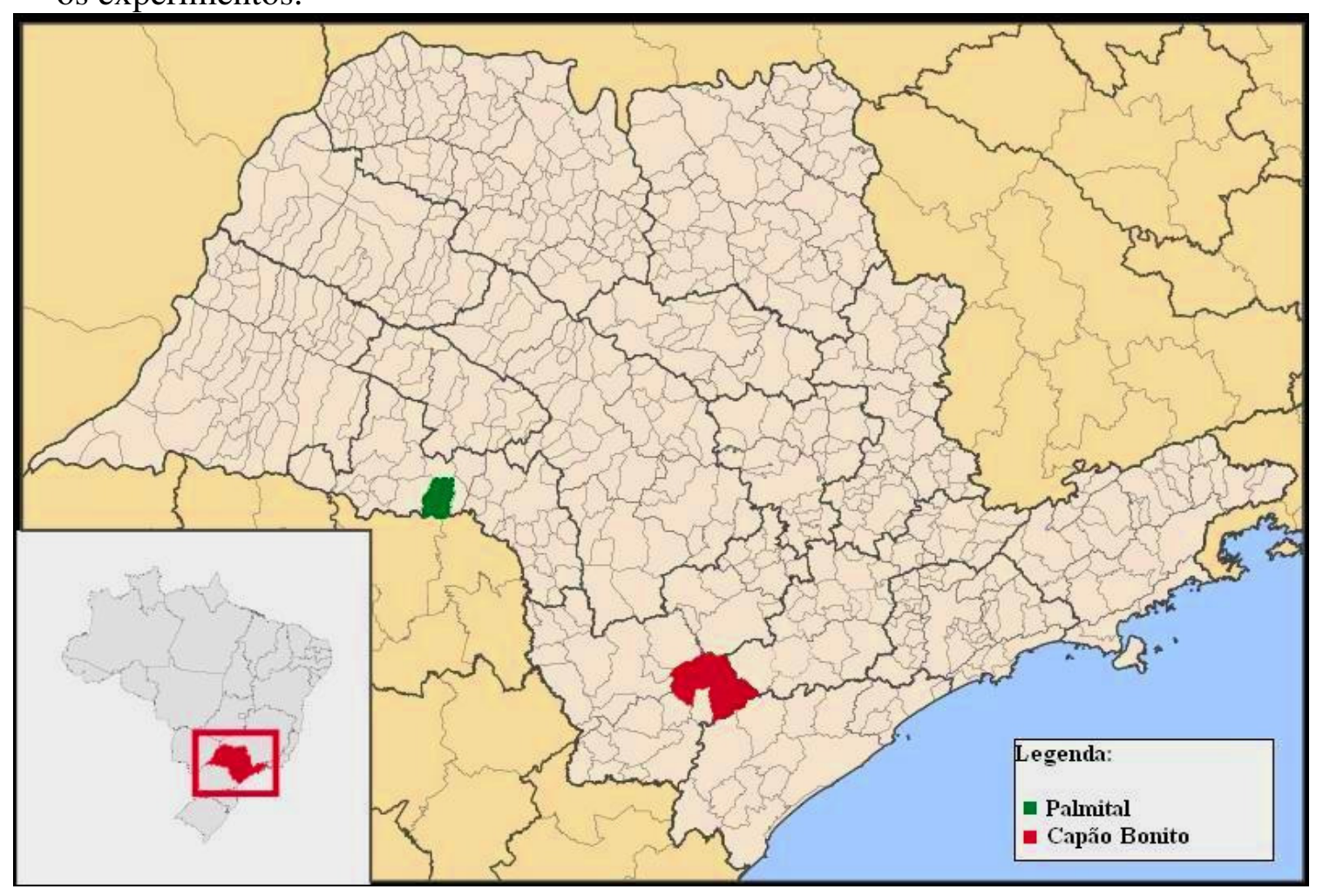

\subsection{Tratamentos e Delineamento Experimental}

Foi utilizado o delineamento em blocos as acaso com quatro tratamentos e quatro repetições, totalizando 16 parcelas no campo.

Os tratamentos foram constituídos por sistemas de rotação de culturas durante três ciclos, incluindo as culturas de soja e milho na safra verão 2010/2011, de trigo e milho 
safrinha na safra de outono-inverno 2011, e apenas milho na safra verão 2011/12, descritos nas Tabelas 1 e 2, e simplificados da seguinte maneira:

- Tratamento 1 (T1): milho/trigo/milho;

- Tratamento 2 (T2): milho/milho safrinha/milho;

- Tratamento 3 (T3): soja/trigo/milho;

- Tratamento 4 (T4): soja/milho safrinha/milho

Ressalta-se que a monocultura (T2) foi comparada com o sistema de rotação durante três cultivos sucessivos, permitindo as comparações entre os tratamentos, e que o histórico da área diferiu nas duas regiões de acordo com a cultura predominante: milho safrinha no Médio Paranapanema e aveia na região sudoeste do Estado de São Paulo (Tabelas 1 e 2).

Tabela 1 - Histórico de uso da área (2009/10) e descrição da sequência de culturas por época e tratamento, em Palmital (SP).

\begin{tabular}{cccccc}
\multirow{2}{*}{ Tratamento } & \multicolumn{2}{c}{ 2009/10 } & & $2010 / 11$ & $2011 / 12$ \\
\cline { 2 - 6 } & Verão & Outono-Inverno & Verão & Outono-Inverno & Verão \\
\hline $\mathbf{1}$ & Soja & Milho Safrinha & Milho & Trigo & Milho \\
\hline $\mathbf{3}$ & Soja & Milho Safrinha & Milho & Milho Safrinha & Milho \\
\hline $\mathbf{4}$ & Soja & Milho Safrinha & Soja & Trigo & Milho \\
\hline Soja & Milho Safrinha & Soja & Milho Safrinha & Milho \\
\hline
\end{tabular}

Tabela 2 - Histórico de uso da área (2009/10) e descrição da sequência de culturas por época e tratamento, em Capão Bonito (SP).

\begin{tabular}{cccccc}
\multirow{2}{*}{ Tratamento } & \multicolumn{2}{c}{$\mathbf{2 0 0 9 / 1 0}$} & & $2010 / 11$ & $2011 / 12$ \\
\cline { 2 - 6 } & Verão & Outono-Inverno & Verão & Outono-Inverno & Verão \\
\hline $\mathbf{1}$ & Soja & Aveia & Milho & Trigo & Milho \\
\hline $\mathbf{2}$ & Soja & Aveia & Milho & Milho Safrinha & Milho \\
\hline $\mathbf{3}$ & Soja & Aveia & Soja & Trigo & Milho \\
\hline $\mathbf{4}$ & Soja & Aveia & Soja & Milho Safrinha & Milho \\
\hline
\end{tabular}




\subsection{Parcelas Experimentais}

As culturas foram instaladas seguindo as recomendações básicas relativas à exploração das espécies em áreas comerciais, nas duas regiões de estudo (Palmital e Capão Bonito). As semeaduras foram realizadas em outubro, nas safras de verão, e nos meses de março e abril, no outono-inverno ou safrinha, adotando o sistema de plantio direto na palha.

Vale ressaltar que não foi possível realizar a coleta de grãos de milho safrinha (safra outono-inverno 2011) devido a ocorrência de geadas nas duas regiões na segunda quinzena de junho, as quais dizimaram o experimento.

As parcelas foram constituídas por 12 linhas de 20 metros de comprimento, espaçadas a 0,8 m entre linhas para o milho; 21 linhas de 20 metros de comprimento, espaçadas a 0,45 m entre linhas para a soja e 48 linhas de 20 metros de comprimento, espaçadas a 0,2 m entre linhas para o trigo, considerando-se, para todos os tratamentos, parcelas úteis apenas as linhas centrais, desprezando-se 1,0 m de cada extremidade e as linhas laterais inteiras.

\subsection{Cultivares e tratos culturais}

Foram utilizados híbridos de milho transgênico Bt (2B710 HX) com ampla adaptação produtiva no Estado de São Paulo, conforme resultados do sistema de avaliação IAC/APTA/CATI.

Para a soja e trigo, também foram utilizados cultivares com ampla adaptação produtiva.

Em cada ciclo, os híbridos foram os mesmos nas duas regiões.

\subsection{Amostragens}

\subsubsection{Cobertura Morta}

Foram coletadas 20 sub-amostras/parcela, de cada tratamento, de maneira aleatória, para formar uma única amostra. Obtivemos 16 amostras por região e em cada ciclo de cultivo, portanto, no total, foram analisadas 64 amostras de cobertura morta (32 por região) (Figuras 7 , 8, 9 e 10; Tabela 3). 
Figura 7 - Coleta de amostra de cobertura morta na região de Capão Bonito.

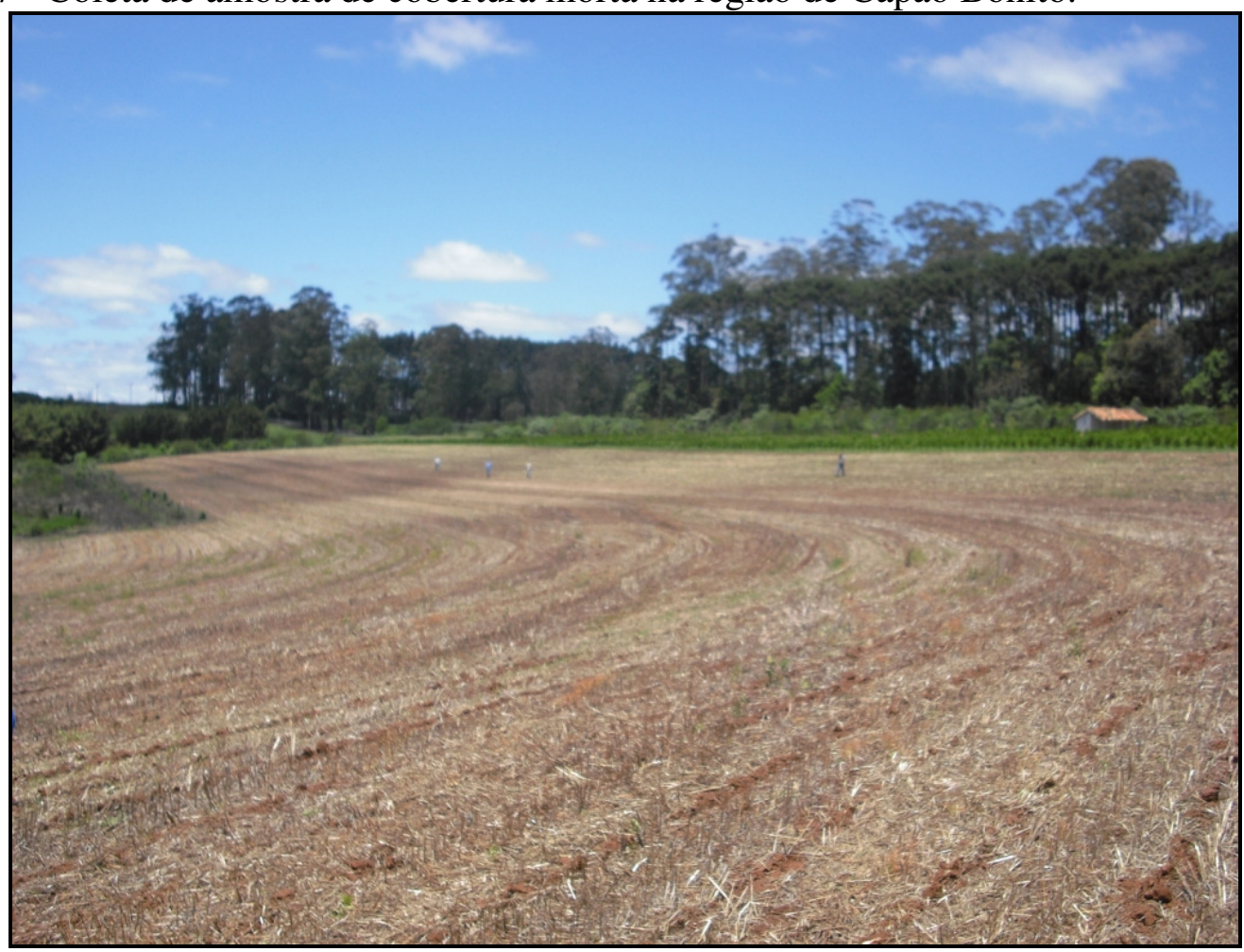

Figura 8 - Coleta de amostra de cobertura morta em Capão Bonito.

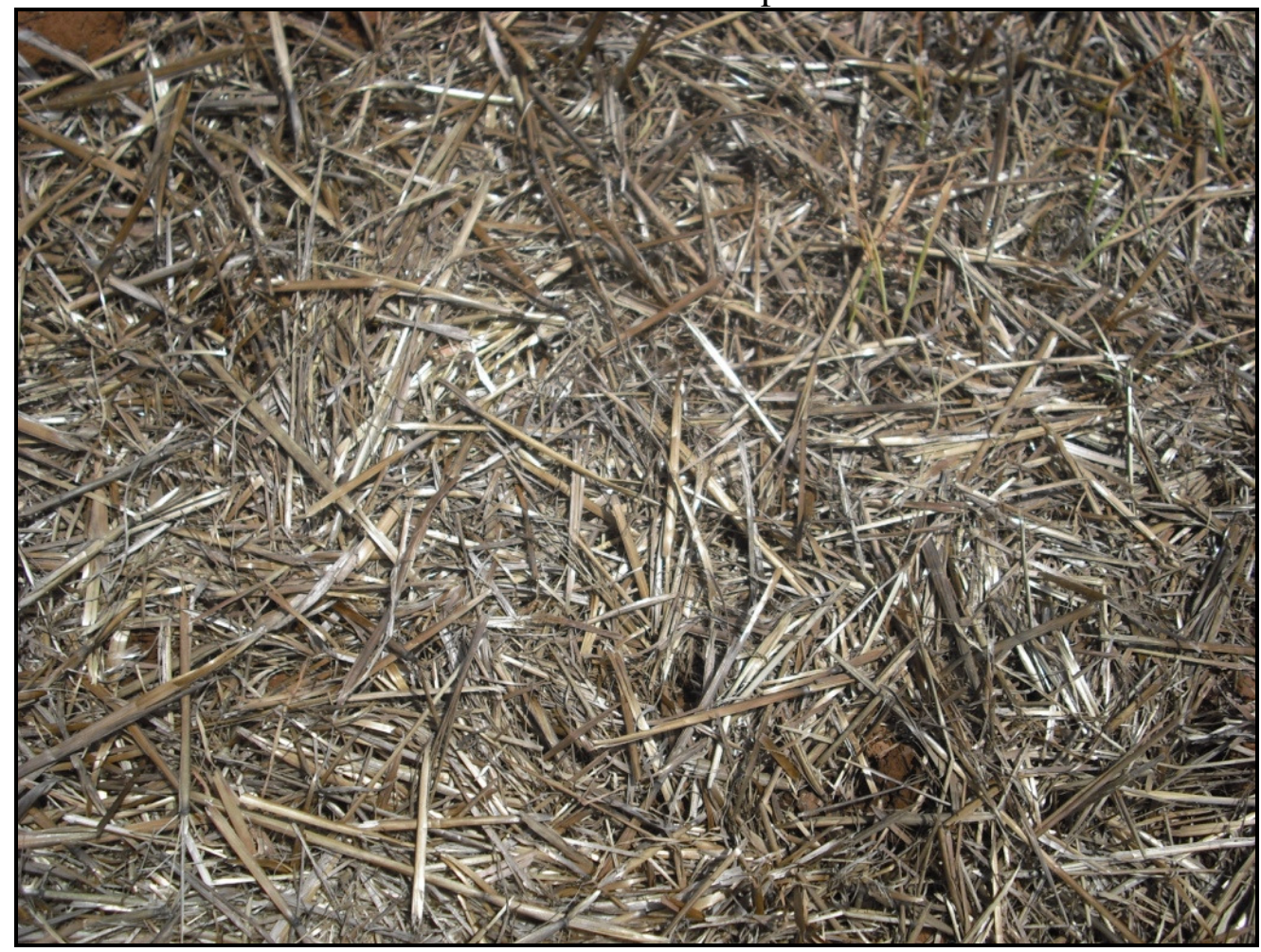


Figura 9 - Coleta de amostra de cobertura morta na região de Palmital.

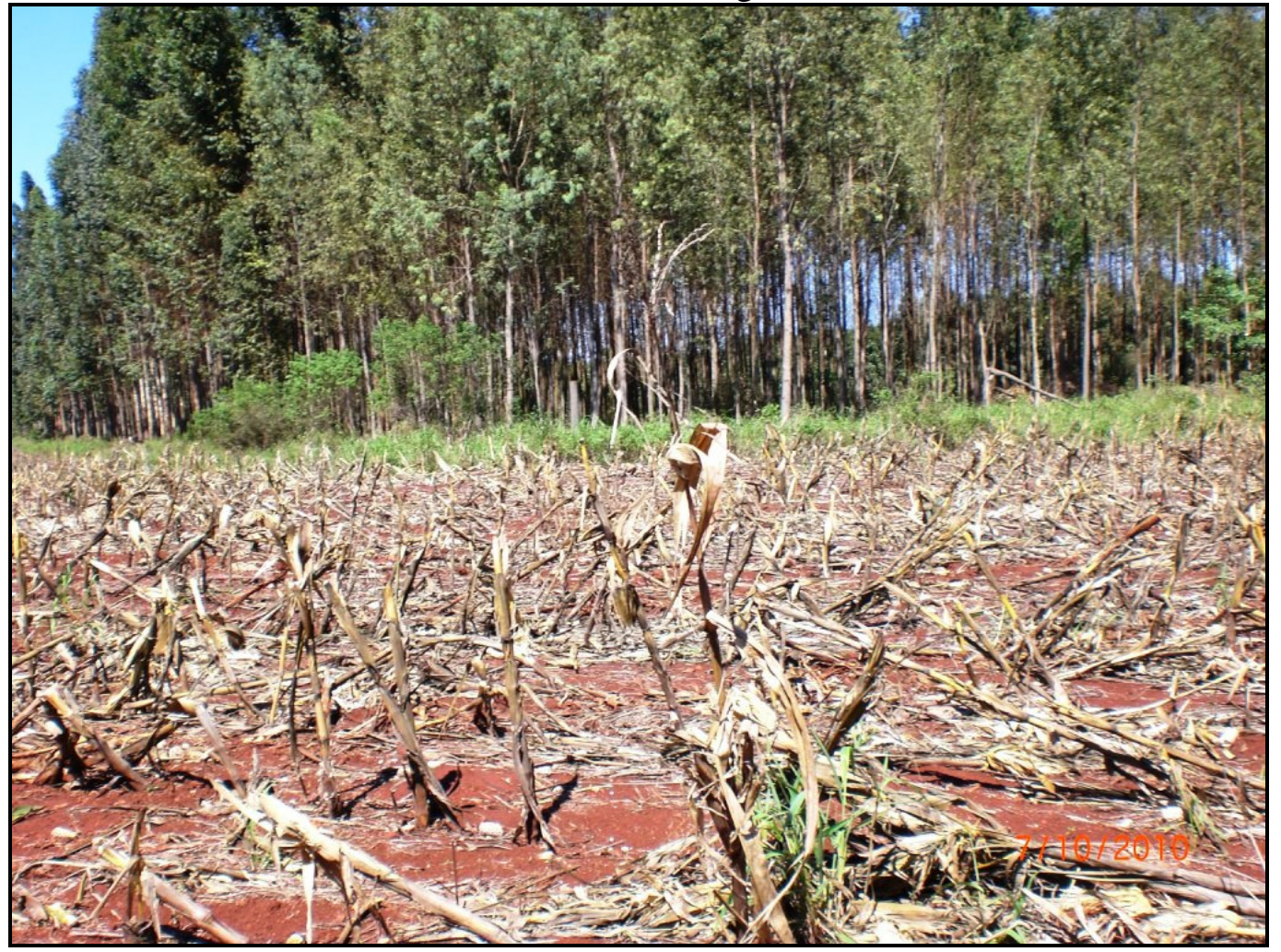

Figura 10 - Coleta de amostra de cobertura morta em Palmital.

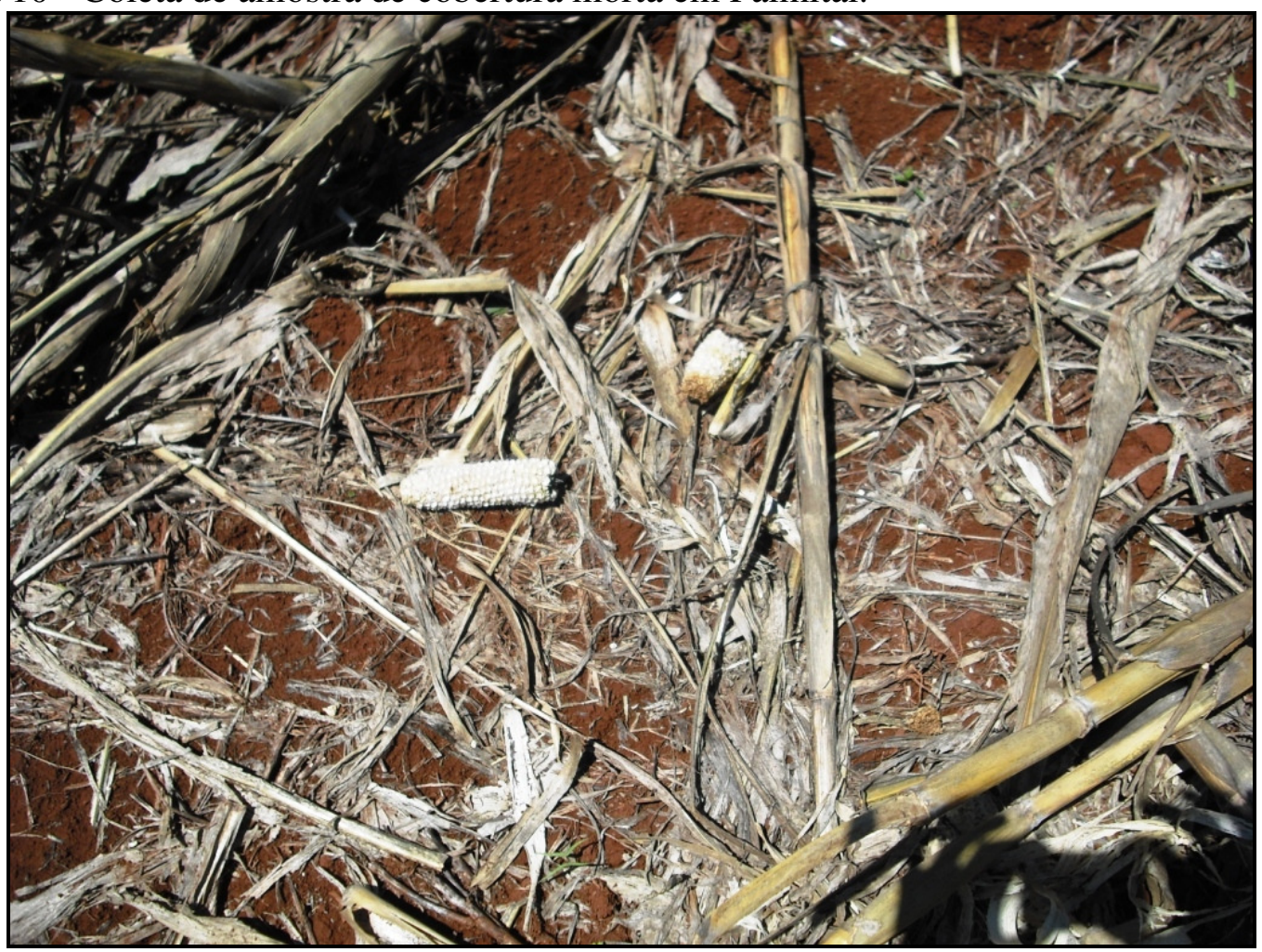


As amostras de cobertura morta provenientes da região de Palmital foram constituídas por restos de milho ( $1^{\mathrm{a}}$ coleta) e milho/trigo ( $2^{\mathrm{a}}$ coleta). As amostras de Capão Bonito foram constituídas de aveia ( $1^{\mathrm{a}}$ coleta $)$ e trigo/milho ( $2^{\mathrm{a}}$ coleta $)$.

As coletas foram realizadas antes da semeadura do milho.

\subsubsection{Grãos do Milho}

Para a amostragem dos grãos do milho, foi utilizada a metodologia adaptada de Delp, Stewell e Marois (1986), onde foram coletadas três amostras de diferentes pontos de cada uma das parcelas plantadas com milho, por ciclo de cultivo e em cada região, totalizando 144 amostras (72 por região) (Tabela 3). As coletas das amostras foram realizadas no final do ciclo da cultura, após a maturidade fisiológica dos grãos (Figuras 11, 12, 13 e 14).

Figura 11 - Coleta de amostra de grãos de milho na região de Palmital.

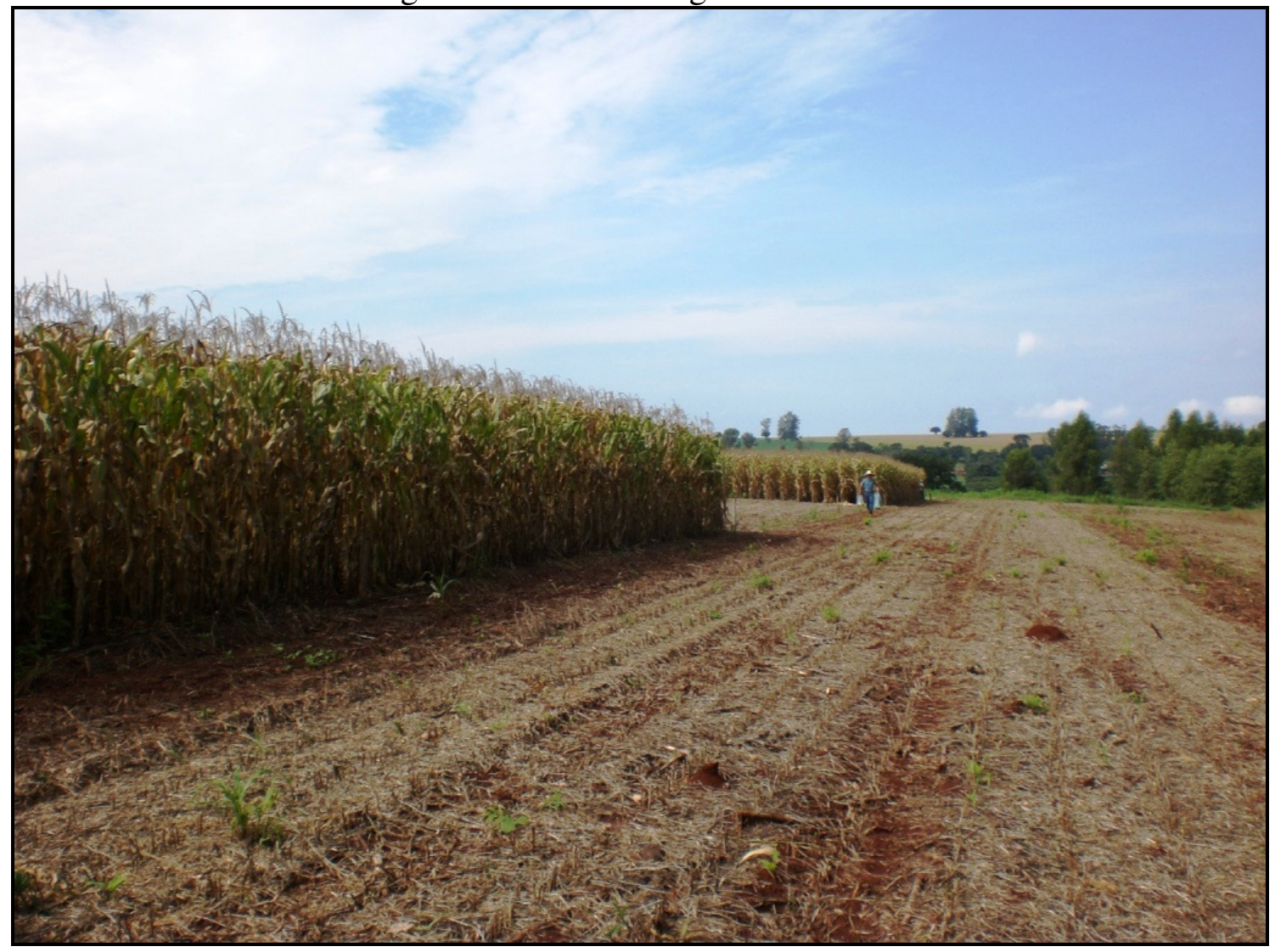


Figura 12 - Amostra de milho coletado em Palmital.

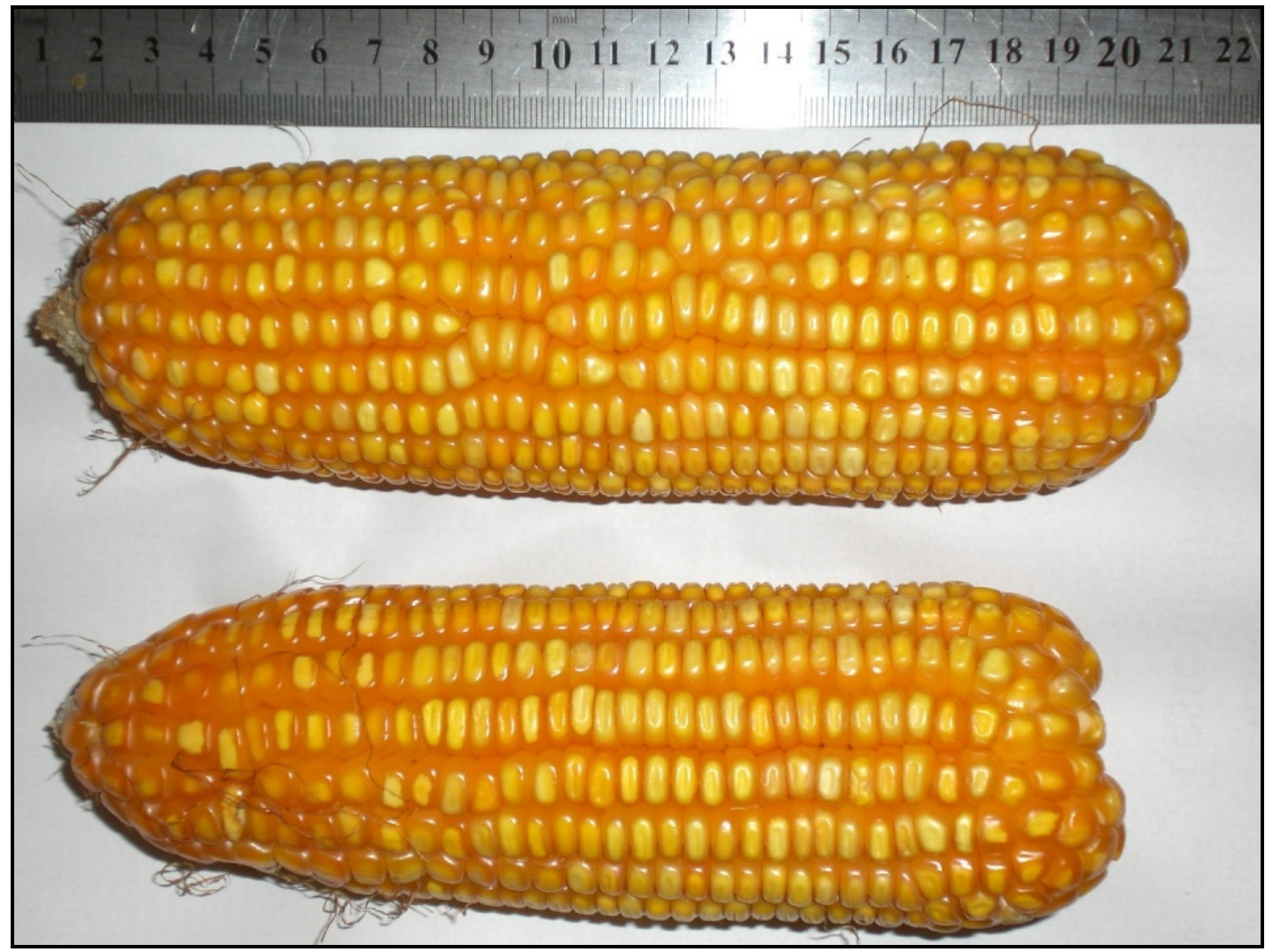

Figura 13 - Coleta de amostra de grãos de milho na região de Capão Bonito.

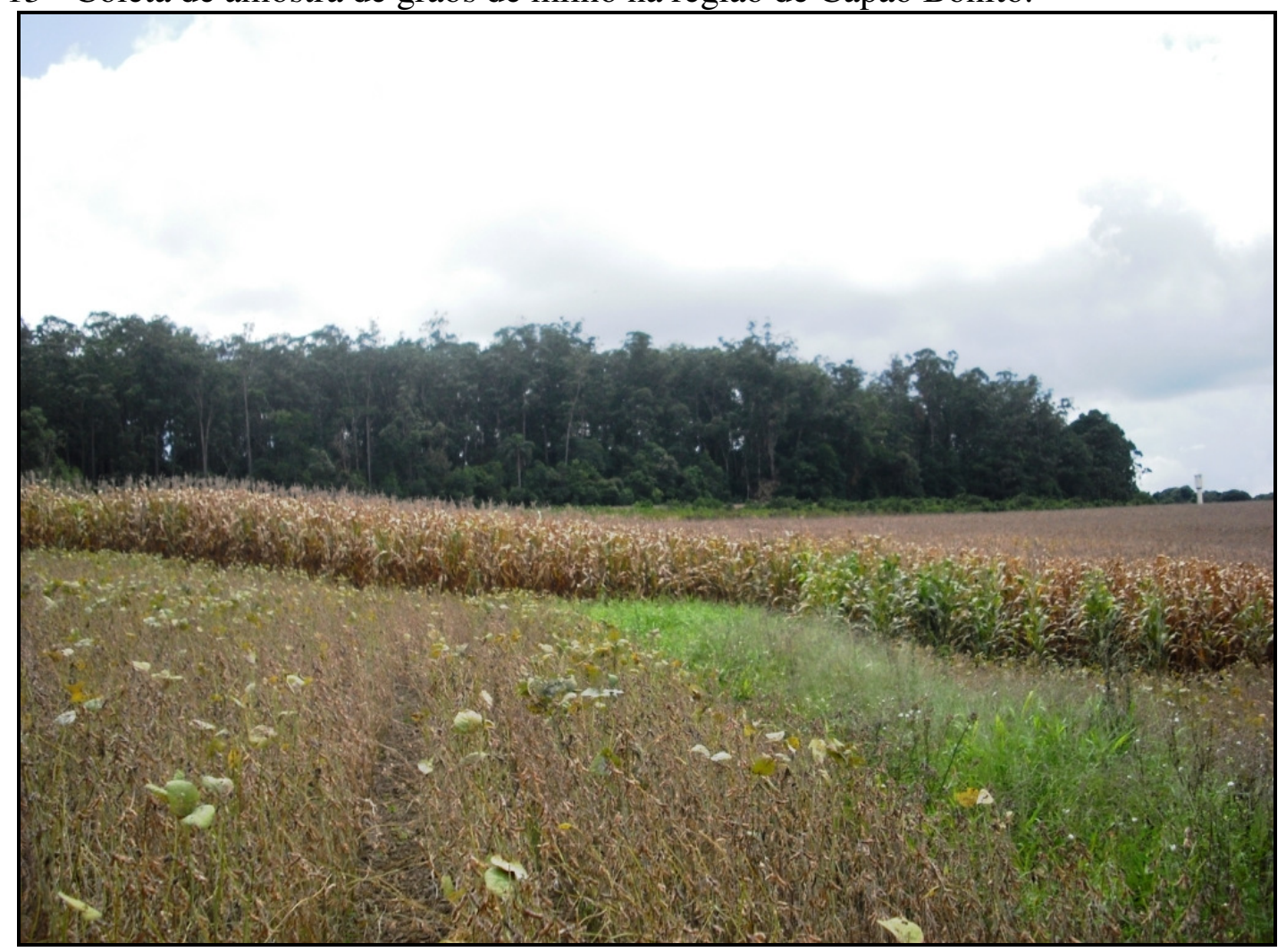


Figura 14 - Coleta de amostras de milho em Capão Bonito.

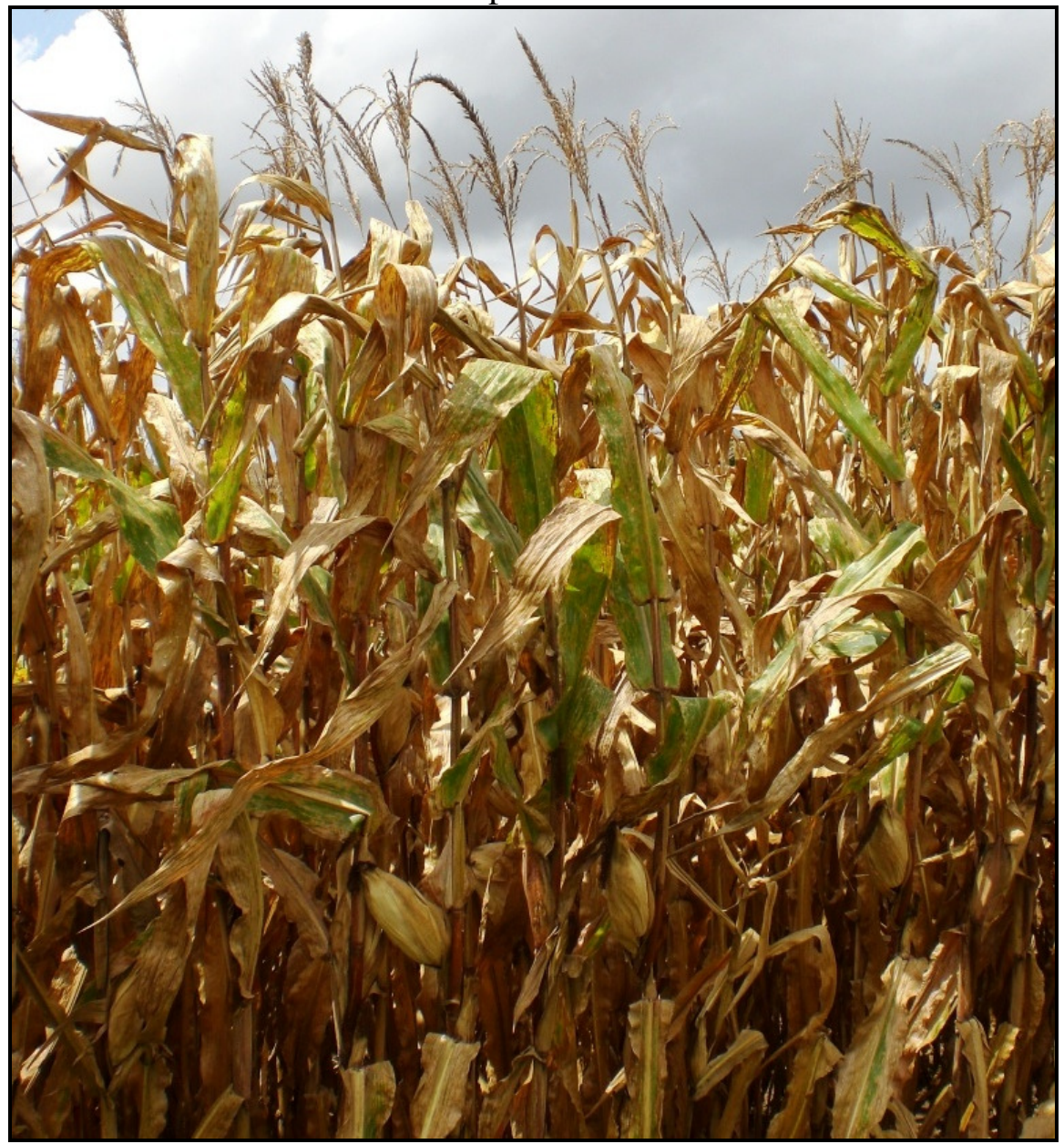

Tabela 3 - Quantidade de amostras de cobertura morta e de grãos de milho coletadas, divididas em duas coletas, e quantidade total de amostras analisadas de cada região.

\begin{tabular}{ccc|ccc}
\hline \multirow{4}{*}{ Regiões } & Cobertura Morta & \multicolumn{2}{c}{ Milho } & Total \\
\cline { 2 - 5 } & $\mathbf{1}^{\text {a }}$ coleta & $\mathbf{2}^{\text {a }}$ coleta & $\mathbf{1}^{\text {a }}$ coleta & $\mathbf{2}^{\text {a }}$ coleta & \\
\hline Palmital & 16 & 16 & 24 & 48 & 104 \\
\hline Capão Bonito & 16 & 16 & 24 & 48 & 104 \\
\hline
\end{tabular}




\subsection{Avaliações Laboratoriais}

\subsubsection{Determinação de Atividade de Água (Aa)}

As Aa nas amostras de milho e cobertura morta foram realizadas por meio do aparelho AQUALAB CX-2 (Decagon Devices Inc.) (Figura 15). As amostras foram acondicionadas no recipiente de medida e as Aa mensuradas em duplicata, utilizando o método do ponto de orvalho. Esse método consiste em uma câmara que contém um espelho. A amostra é colocada em um recipiente que no interior da câmara. Aguarda-se certo tempo até que o equilíbrio seja atingido. O espelho é resfriado por um elemento termoelétrico eletrônico (Peltier). Com o resfriamento, gotas de condensado se formarão na superfície do espelho, que serão determinadas por uma célula fotoelétrica. Um sensor de infravermelho mede a temperatura da amostra. Um ventilador acelera o processo de modo que o equilíbrio é atingido mais rapidamente. Um microprocessador interno usa os dados da temperatura para calcular a Aa (DITCHFIELD, 2000).

Figura 15 - Aparelho Aqualab CX-2.

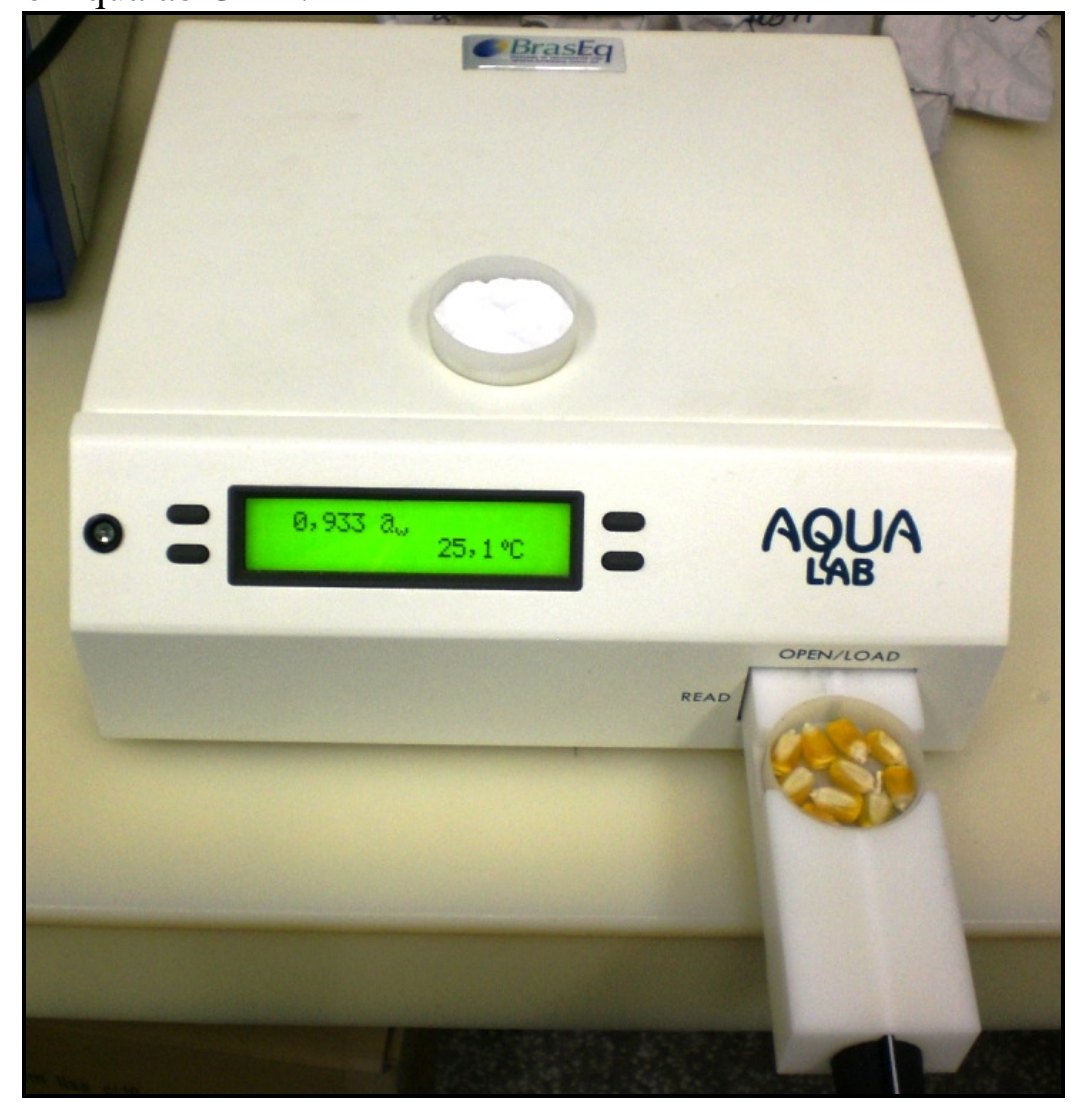




\subsubsection{Técnica da Semeadura Direta para o Isolamento da Micobiota dos Grãos de Milho}

Utilizando a metodologia proposta por Berjak (1984), de cada uma das sub-amostras $(1 \mathrm{Kg})$ de grãos de milho, previamente homogeneizadas, foram retiradas aproximadamente 30 g para desinfecção em solução de hipoclorito de sódio $0,4 \%$ por 3 minutos, seguida de lavagens vigorosas com água destilada esterilizada para eliminação dos contaminantes externos. Após a desinfecção, 33 grãos foram selecionados ao acaso e semeados diretamente em 3 placas de Petri contendo Ágar Dicloran Rosa Bengala Cloranfenicol (DRBC) (Oxoid, Basingstoke, Hampshire, England) (PITT; HOCKING, 2009) (Figura 16). Cada placa contendo 11 grãos foi incubada a $25^{\circ} \mathrm{C}$ por 5 dias e os resultados expressos em porcentagem do total de grãos semeados. As colônias de diferentes tipos morfológicos foram isoladas em Ágar Batata Dextrose (Oxoid) e submetidas à identificação através da técnica de microcultivo (RIDDELL, 1950). Os fungos foram classificados em nível de gênero, entretanto aqueles pertencentes ao gênero Fusarium foram identificados até espécie através de metodologia clássica, de acordo com nomenclatura proposta por Leslie e Summerell (2006), Nelson, Touson e Marasas (1983) e Nelson (1992), e molecular, através do sequenciamento parcial do gene do fator de elongação $1 \alpha$, utilizando os primers ef- 1 e ef-2, como descrito por Geiser et al., 2004.

Figura 16 - Técnica da semeadura direta para o isolamento da micobiota dos grãos de milho.

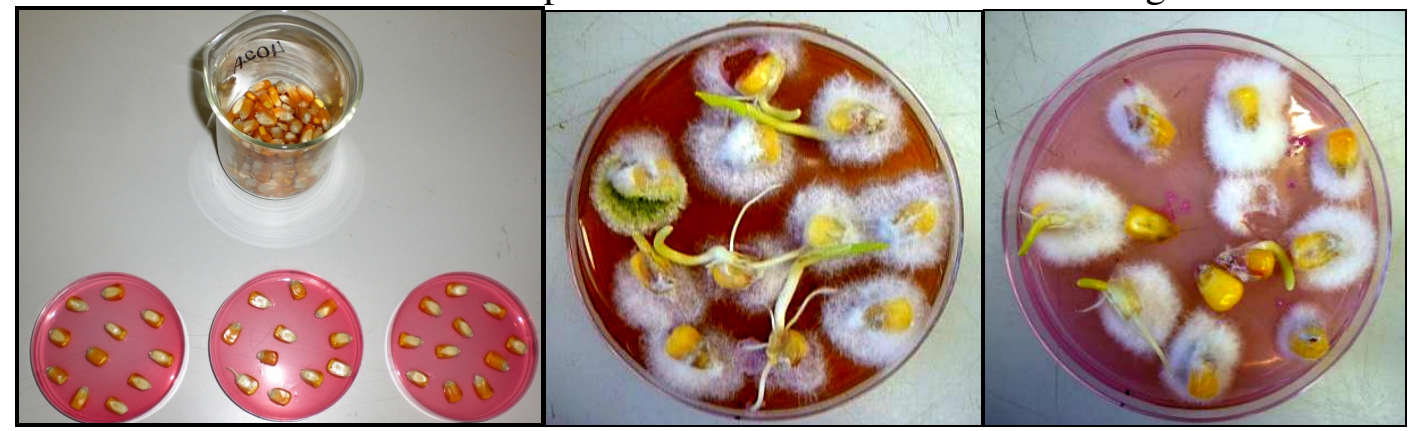

3.6.3 Técnica da Semeadura em Superfície para o Isolamento da Micobiota das Amostras de Cobertura Morta

Foram retiradas $10 \mathrm{~g}$ de cada amostra de cobertura morta e diluídas em $90 \mathrm{~mL}$ de solução salina $0,85 \%$ esterilizada, obtendo-se diluição de $10^{-1}$. A partir desta, foram preparadas diluições decimais e sucessivas até $10^{-6}$. De cada diluição, $0,1 \mathrm{~mL}$ foram retirados 
e depositados na superfície de placas de Petri contendo de 10 a $15 \mathrm{~mL}$ de Ágar Base Dicloran Glicerol Cloranfenicol (DG18) (Oxoid). Em seguida, as placas foram incubadas a $25{ }^{\circ} \mathrm{C}$ por aproximadamente até 7 dias (Figura 17). Todas as amostras foram processadas em duplicatas (PITT; HOCKING, 2009). Após a incubação, foi feita a contagem das colônias multiplicandose o número obtido pelo fator de diluição, a fim de se obter o número de unidades formadoras de colônia por grama de substrato (UFC/g).

As colônias de diferentes tipos morfológicos foram isoladas em Ágar Batata Dextrose (Oxoid) e submetidas à identificação através da técnica de microcultivo (RIDDELL, 1950). Os fungos foram classificados em nível de gênero, entretanto aqueles pertencentes ao gênero Fusarium foram identificados até espécie através de metodologia clássica, de acordo com nomenclatura proposta por Leslie e Summerell (2006), Nelson, Touson e Marasas (1983) e Nelson (1992), e molecular, através do sequenciamento parcial do gene do fator de elongação $1 \alpha$, utilizando os primers ef-1 e ef-2, como descrito por Geiser et al., 2004.

Figura 17 - Semeadura em superfície para o isolamento da micobiota das amostras de cobertura morta.

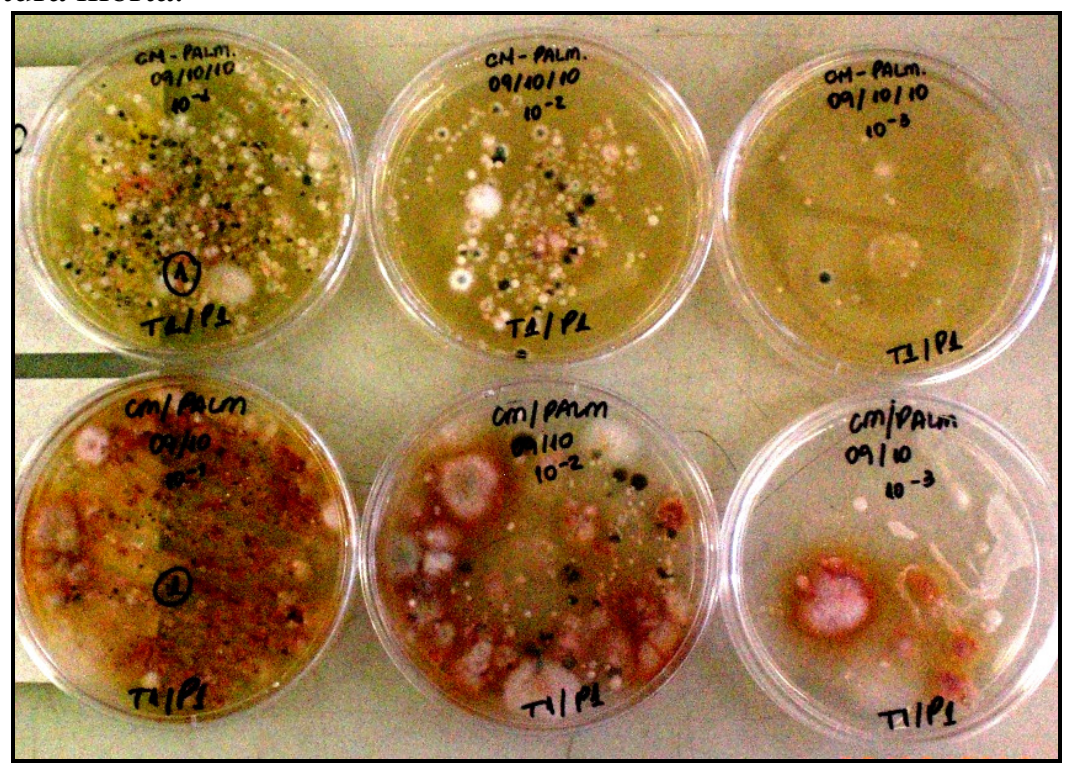




\subsubsection{Identificação dos Isolados de Fusarium spp. pelo Sequenciamento Parcial do Gene $\underline{\text { TEF- } 1 \alpha}$}

\subsubsection{Extração de DNA Genômico}

Para a obtenção da biomassa fúngica, as cepas de Fusarium spp. isoladas tanto das amostras de cobertura morta quanto das amostras de milho foram semeadas em meio Yeast Extract Sucrose - YES (Extrato de levedura 2\%, Sacarose 15\% e Ágar bacteriológico 2\%). O DNA ribossomal foi extraído e purificado diretamente das colônias fúngicas a partir do cultivo em ágar YES (ABDOLLAHI; BUCHANAN, 1981; DEGOLA et al., 2007), seguindo o kit do protocolo PrepMan Ultra ${ }^{\circledR}$ (Applied Biosystems, Foster City, CA, USA). Para tal, os isolados foram inoculados em ágar YES e cultivados por 3 dias em estufa a $25{ }^{\circ} \mathrm{C}$, em seguida, com o auxílio de um bisturi, um fragmento de micélio de aproximadamente $0,5 \mathrm{~cm}^{2}$ foi recortado da periferia da colônia. Removeu-se o ágar, e o micélio foi transferido para um microtubo de 1,5 mL contendo $300 \mu \mathrm{L}$ de PrepMan Ultra ${ }^{\circledR}$. O microtubo foi agitado em vortex por um minuto e colocado em banho de água a $100{ }^{\circ} \mathrm{C}$ por 15 minutos e centrifugado por 7 minutos a $14000 \mathrm{rpm}$ em temperatura ambiente. Após, o sobrenadante foi transferido para outro microtubo de $1,5 \mathrm{~mL}$ e armazenado a $-4^{\circ} \mathrm{C}$ até o momento da quantificação e realização da Reação de Polimerase em Cadeia (PCR).

\subsubsection{Quantificação do DNA Genômico de Fusarium spp.}

O DNA total extraído foi diluído 50 x $(98 \mu \mathrm{L}$ de água Milli-Q e $2 \mu \mathrm{L}$ do DNA da amostra) e posteriormente quantificado em NanoDrop 2000 C (Thermo Scientific Waltham, Massachusetts, USA). A concentração foi calculada diretamente pela equação: Concentração do DNA $(\mathrm{ng} / \mu \mathrm{L})=\mathrm{A}_{260} \times 10 / 4$. Onde, $\mathrm{A}_{260}=$ leitura da absorbância no comprimento de onda de $260 \mathrm{~nm}$. Também foi realizada da medida da absorbância no comprimento de onda de 280 nm para verificar a presença de proteínas e calcular a pureza do DNA através da razão entre A260 nm e A280 nm (DO260/DO280) que apresentou valores entre 1,8 e 2,0. Valores abaixo de 1,8 indicam grande quantidade de contaminantes e proteínas, nesse caso, a extração de DNA foi realizada novamente. 


\subsubsection{Reação de Polimerase em Cadeia (PCR) do Gene TEF-1 $\alpha$}

O protocolo de PCR foi usado para amplificar a região entre os nucleotídeos 75 a 978 do gene TEF-1 $\alpha$ (baseando-se na sequência de Trichoderma reesei, Genebank Acession Number Z23012). Os primers EF1 (forward primer; 5'ATGGGTAAGGA(A/G)GACAAGAC-3') e EF2 (reverse primer; 5'GGA(G/A)GTACCAGT(G/C)ATCATGTT-3') foram utilizados (GEISER et al., 2004; O'DONNELL et al., 1998). Para a PCR foram utilizados microtubos de 0,2 mL, utilizando os seguintes reagentes: 12,5 $\mu \mathrm{L}$ Master Mix ${ }^{\circledR}$ (Promega, Madison, WI); 2,0 $\mu \mathrm{L}$ de cada um dos primers [os primers utilizados foram sintetizados pela IDT (Integrated DNA Technologies, Illinois, USA)]; 2,0 $\mu \mathrm{L}$ de DNA diluído a $40 \mathrm{ng} / \mu \mathrm{L} ; 6,5 \mu \mathrm{L}$ de água Milli-Q, totalizando volume final de $25 \mu \mathrm{L}$. A amplificação do DNA foi realizada em termociclador GeneAmp® PCR System 9700 (Applied Byosistems, Gouda, The Netherlands) programado com ciclo inicial de $94{ }^{\circ} \mathrm{C}$ por $5 \mathrm{~min}$, seguido por 40 ciclos de $95^{\circ} \mathrm{C}$ por 30 segundos, $55^{\circ} \mathrm{C}$ por 1 minuto, $72^{\circ} \mathrm{C}$ por 1 minuto; $72^{\circ} \mathrm{C}$ por 7 minutos. O produto amplificado foi analisado por eletroforese em gel de agarose a 1,2\% em TAE 1x e corado com SYBR safe DNA Gel Stain (Invitrogen, Carlsbad, CA, USA).

\subsubsection{Purificação do DNA}

O produto de PCR do gene TEF-1 $\alpha$ foi purificado por filtração através do kit comercial QIAquick PCR Purification Kit (Qiagen, Hilden, Germany), onde os nucleotídeos não-incorporados e os primers foram removidos. O kit foi otimizado conforme descrito a seguir: ao volume de $20 \mu \mathrm{L}$ do produto de PCR foi adicionado $100 \mu \mathrm{L}$ do Buffer PB - Binding Buffer (Tampão de Ligação) na coluna que acompanha o kit, que foi deixado em repouso por um minuto, centrifugado a 13000 rpm por 1 minuto e descartada a fase inferior do microtubo. Após, foi adicionado $700 \mu \mathrm{L}$ de Buffer PE - Wash Buffer (Tampão de Lavagem), foi deixado em repouso por um minuto, centrifugado a $13000 \mathrm{rpm}$ por 1 minutos e descartado a fase inferior do microtubo. O conjunto foi centrifugado novamente a $13000 \mathrm{rpm}$ por 3 minutos para remoção total do tampão de lavagem. Para eluição, a coluna foi transferida para um novo microtubo de 1,5 mL e adicionando $20 \mu \mathrm{L}$ de EB - Eluiton Buffer (Tampão de Eluição) no centro da coluna, deixado por 1 minuto em repouso e centrifugado $13000 \mathrm{rpm}$ por 1 minuto. 


\subsubsection{Quantificação da PCR purificada}

Após a purificação, foi realizada quantificação do produto de PCR purificado em NanoDrop, onde também foi verificada a pureza do produto conforme explicado no item 4.6.4.2. Para a etapa de sequenciamento, utilizaram-se amostras com valores de pureza estava maior ou igual a 1,80, caso contrário a etapa de PCR foi repetida.

\subsubsection{Reação de Sequenciamento do Produto de PCR do Gene TEF-1 $\alpha$}

As reações de sequenciamento foram realizadas em termociclador Applied Biosystems Thermocycler GeneAmp PCR System 9700.

Os produtos de PCR purificados foram sequenciados bidirecionalmente ("foward" e "reverse") utilizando o kit Big Dye Terminator v3.1. Cycle Sequencing (Applied Biosystems). Os primers utilizados foram os mesmos utilizados na PCR. A reação foi realizada em placa de 96 poços (MicroAmp Optical - 96-Well Reaction Plate com MicroAmp Full Plate Cover, Applied Biosystems), contendo o produto de PCR purificado diluído na quantidade entre $40 \mathrm{ng}$ a $60 \mathrm{ng}$ (adicionando-se água Milli-Q para um volume final $5 \mu \mathrm{L}$ ) adicionado da mistura contendo: $3 \mu \mathrm{L}$ de tampão; $1 \mu \mathrm{L}$ do Big Dye e $1 \mu \mathrm{L}$ do primer na concentração de 3,2 pmol, assim, com volume final de $10 \mu \mathrm{L}$.

As condições das reações foram: 35 ciclos de $95^{\circ} \mathrm{C}$ por 15 segundos, $55^{\circ} \mathrm{C}$ por 20 segundos e $60^{\circ} \mathrm{C}$ por 1 minuto e 30 segundos.

\subsubsection{Precipitação das Reações de Sequenciamento}

Às reações, foram adicionados $40 \mu \mathrm{L}$ de isopropanol 65\%. As amostras foram agitadas e incubadas à temperatura ambiente, protegidas da luz, por 15 minutos. Após centrifugação a $3000 \mathrm{rpm}$ por 30 minutos, o sobrenadante foi descartado e $150 \mu \mathrm{L}$ de etanol $70 \%$ foram adicionados e o material novamente foi centrifugado por 10 minutos a $3800 \mathrm{rpm}$. Em seguida, o sobrenadante foi descartado e o DNA seco a $94{ }^{\circ} \mathrm{C}$ por 4 minutos em termociclador GeneAmp PCR System 9700 (Applied Biosystems).

As amostras foram ressuspendidas em $10 \mu \mathrm{L}$ de formamida Hi-Di (Applied Biosystems), desnaturadas a $95{ }^{\circ} \mathrm{C}$ por 2 minutos e incubadas no gelo por 1 minuto. Em seguida, foram aplicadas aos capilares contendo polímero POP6 do sequenciador automático ABI PRISM 3100 Genetic Analyser (Applied Biosystems). 
3.6.4.8 Análise das Sequências do Gene TEF-1a das Amostras de Fusarium spp.

As sequências do gene TEF-1 $\alpha$ dos isolados de Fusarium spp. foram editadas utilizando-se o software BioEdit v7.0.9.0 (Figura 18) e posteriormente alinhadas com a ferramenta BLAST, utilizando as sequências depositadas no GeneBank (http://blast.ncbi.nlm.nih.gov/Blast.cgi) e no Fusarium ID $\quad$ v1.0 (Figura 19) (http://isolate.fusariumdb.org/index.php) (GEISER et al., 2004).

Figura 18 - Sequências do gene TEF-1 $\alpha$ dos isolados de Fusarium spp. editadas no software BioEdit Sequence Alignment Editor.

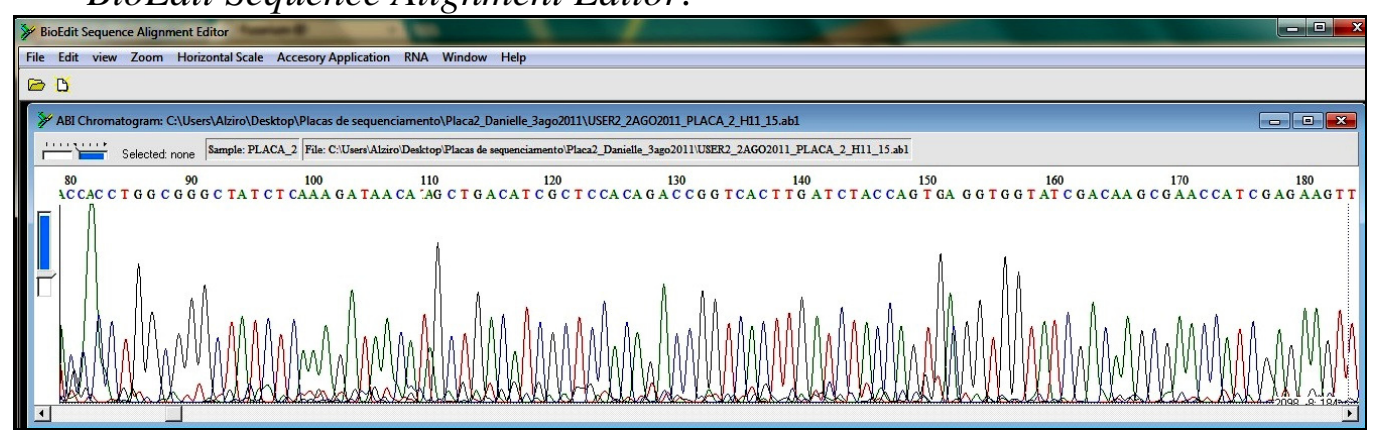

Figura 19 - Alinhamento das sequências do gene TEF-1 $\alpha$ dos isolados de Fusarium spp. no banco de dados do Fusarium ID v1.0.

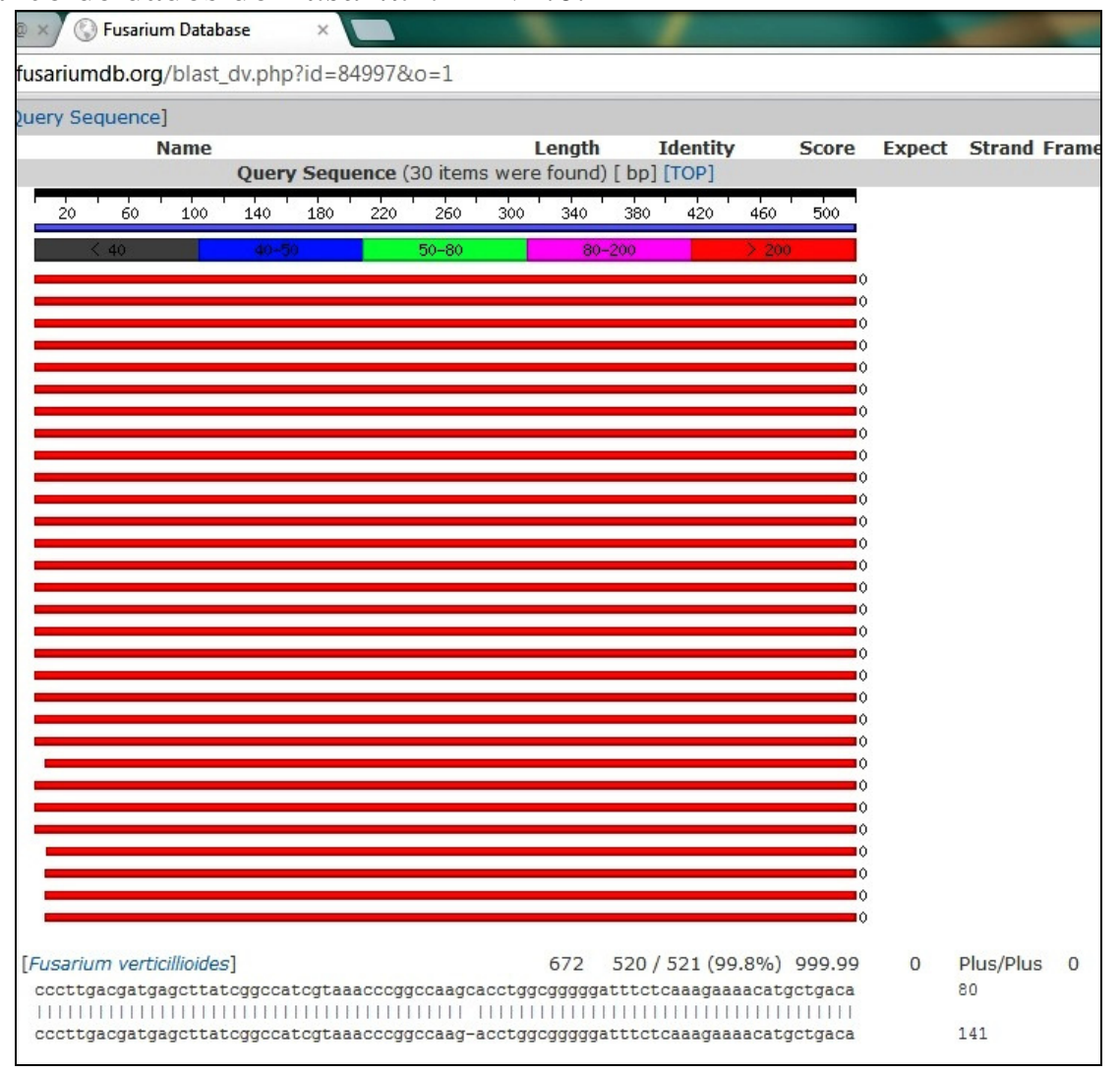




\subsubsection{Avaliação da metodologia analítica para as fumonisinas $\mathrm{B}_{1} \underline{\mathrm{e}}_{2}$}

O método foi avaliado de acordo com os seguintes parâmetros: porcentagem de recuperação e limite de quantificação.

\subsubsection{Construção das curvas de calibração}

Foram construídas duas curvas de calibração para cada fumonisina ( $\mathrm{FB}_{1}$ e $\left.\mathrm{FB}_{2}\right)$, uma com valores de 0,3125 a $10,0 \mu \mathrm{g} / \mathrm{mL}$ e a outra com valores entre 0,039 e $0,3125 \mu \mathrm{g} / \mathrm{mL}$ (Tabelas 4 e 5), para que todos os valores obtidos nas análises de fumonisinas das amostras de milho e do potencial toxigênico das cepas de $F$. verticillioides estivessem dentro de uma das duas curvas.

As soluções calibradoras de $\mathrm{FB}_{1}$ e $\mathrm{FB}_{2}$ foram preparadas em acetonitrila:água (50:50, v/v) com uma concentração final de $50 \mu \mathrm{g} / \mathrm{mL}$ para $\mathrm{FB}_{1}$ e $\mathrm{FB}_{2}$. As soluções foram diluídas para a obtenção de uma concentração de $10 \mu \mathrm{g} / \mathrm{mL}$ para $\mathrm{FB}_{1}$ e $\mathrm{FB}_{2}$. Foram preparadas mais oito diluições para a realização das curvas de calibração e verificação da linearidade. As soluções tiveram limites variando entre 0,039 - 10,000 $\mu \mathrm{g} / \mathrm{mL}$ para $\mathrm{FB}_{1}$ e $\mathrm{FB}_{2}$ (Tabelas 4 e 5).

Tabela 4 - Concentração das soluções para a curva de calibração 1.

\begin{tabular}{cc} 
Soluções calibradoras & Concentração de $\mathbf{F B}_{\mathbf{1}}$ e $\mathbf{F B}_{\mathbf{2}}$ em $\boldsymbol{\mu g} / \mathbf{M l}$ \\
\hline 1 & 0,3125 \\
2 & 0,625 \\
3 & 1,25 \\
4 & 2,5 \\
5 & 5,0 \\
6 & 10,0 \\
\hline
\end{tabular}

Tabela 5 - Concentração das soluções para a curva de calibração 2.

\begin{tabular}{cc} 
Soluções calibradoras & Concentração de $\mathbf{F B}_{\mathbf{1}} \mathbf{e} \mathbf{F B}_{\mathbf{2}} \mathbf{e m} \boldsymbol{\mu \mathrm { g } / \mathrm { mL }}$ \\
\hline 1 & 0,039 \\
2 & 0,078 \\
3 & 0,156 \\
4 & 0,3125 \\
\hline
\end{tabular}




\subsubsection{Avaliação da recuperação}

O estudo da recuperação das fumonisinas foi realizado pela adição de quantidades conhecidas de $\mathrm{FB}_{1}$ e $\mathrm{FB}_{2}$ às amostras de milho provenientes do campo com concentrações não detectáveis de fumonisinas, nas condições de nosso experimento.

Em 20 g de amostras de grãos de milho foram adicionados padrões de fumonisinas, em triplicata, nas seguintes concentrações: $15,0 \mu \mathrm{g} / \mathrm{kg}, 25,0 \mu \mathrm{g} / \mathrm{kg}, 50,0 \mu \mathrm{g} / \mathrm{kg}, 85,0 \mu \mathrm{g} / \mathrm{kg}, 150,0$ $\mu \mathrm{g} / \mathrm{kg}$ e $300,0 \mu \mathrm{g} / \mathrm{kg}$ para $\mathrm{FB}_{1}$ e $15,0 \mu \mathrm{g} / \mathrm{kg}, 25,0 \mu \mathrm{g} / \mathrm{kg}, 50,0 \mu \mathrm{g} / \mathrm{kg}, 85,0 \mu \mathrm{g} / \mathrm{kg} 150,0 \mu \mathrm{g} / \mathrm{kg}$ e $300,0 \mu \mathrm{g} / \mathrm{kg}$ para $\mathrm{FB}_{2}$. Em seguida, as amostras foram submetidas à metodologia proposta por Visconti, Solfrizzo e Girolamo (2001).

\subsubsection{Determinação do limite de quantificação}

O limite de quantificação (LQ), menor concentração medida precisamente (CHASIN; CHASIN; SALVADORI, 1994), foi determinado a partir da adição de quantidades decrescentes dos padrões às amostras com concentrações não detectáveis de toxinas (nas condições de nosso experimento), baseadas nas estimativas dos teores de fumonisinas no milho e do estudo da recuperação do método. A quantificação foi realizada através de curva de calibração.

\subsubsection{Determinação de Fumonisinas das Amostras de Milho}

\subsubsection{Extração e Purificação de Fumonisinas das Amostras}

Foram transferidos para um frasco $20 \mathrm{~g}$ de cada amostra previamente triturada e adicionados $100 \mathrm{~mL}$ de acetonitrila:metanol:água (25:25:50, v/v/v). Após agitação por 45 minutos, em agitador mecânico horizontal, as amostras foram filtradas em papel de filtro (Whatman $\mathrm{n}^{\mathrm{o}}$ 4). Foram pipetados $10 \mathrm{~mL}$ do filtrado, adicionados $40 \mathrm{~mL}$ de tampão fosfato (PBS) pH 7,0 e agitados. Os extratos diluídos foram filtrados em papel de filtro de microfibra e, em seguida, coletados $10 \mathrm{~mL}$ para a purificação em coluna de imunoafinidade (fluxo de 1 $\mathrm{mL} /$ minuto). Posteriormente, a coluna foi lavada com $10 \mathrm{~mL}$ de PBS (tampão fosfato, $\mathrm{pH}$ 7,0). As fumonisinas foram eluídas com 1,5 mL de metanol grau CLAE, evaporadas até 
resíduo em banho-maria sob nitrogênio e mantidas a $-4^{\circ} \mathrm{C}$ até o momento da detecção e quantificação (VISCONTI; SOLFRIZZO; GIROLAMO, 2001).

\subsubsection{Cromatografia Líquida de Alta Eficiência}

Os extratos obtidos, como descrito no item anterior, foram ressuspendidos em $100 \mu \mathrm{L}$ de acetonitrila:água (50:50, v/v). Uma alíquota de $50 \mu \mathrm{L}$ foi submetida à reação com $50 \mu \mathrm{L}$ de ortoftaldeído (OPA) $(40 \mathrm{mg}$ de OPA dissolvidos em $1 \mathrm{~mL}$ de metanol, diluídos em $5 \mathrm{~mL}$ de $0,1 \mathrm{M}$ de tetraborato de sódio, contendo $50 \mu \mathrm{L}$ de mercaptoetanol). Esta reação foi mantida à temperatura ambiente $\left(25^{\circ} \mathrm{C}\right)$ sob abrigo de luz e, após 2 minutos da adição da solução contendo OPA, foi injetada em cromatógrafo líquido (Shimadzu, modelo LC-10AD, equipado com injetor e "loop" fixo de $20 \mu \mathrm{L}$, Rheodyne). Após a separação em coluna de fase reversa C-18 (5 $\mu$, ODS-20, 150 x 4,6 mm, Phenomenex), os derivados das fumonisinas $\mathrm{B}_{1}$ e $\mathrm{B}_{2}$ presentes na solução foram detectados em detector de fluorescência (modelo RF-10AXL), com comprimentos de onda de 335 e 440 nm (excitação e emissão, respectivamente). Como fase móvel foi utilizada uma solução de acetonitrila:água:ácido acético (49:51:2, v/v/v) em modo isocrático. A vazão foi de $1,4 \mathrm{~mL} / \mathrm{min}$ e a temperatura da coluna foi mantida em forno à $30{ }^{\circ} \mathrm{C}$ (VISCONTI; SOLFRIZZO; GIROLAMO, 2001)..

\subsubsection{Avaliação do Potencial Toxigênico das Cepas de F. verticillioides Isoladas Durante o Estudo}

Em tubo cônico para centrífuga (tubo tipo falcon, com capacidade para $50 \mathrm{~mL}$ ), contendo $10 \mathrm{~g}$ de arroz esterilizado, foi inoculado $1 \mathrm{~mL}$ de suspensão de esporos obtidos do cultivo de cepas de $F$. verticillioides cultivadas em Ágar Batata Dextrose a $25^{\circ} \mathrm{C}$ por 7 dias. Os tubos cônicos foram incubados por um período de 15 dias a $25^{\circ} \mathrm{C}$ seguido por mais um período de 15 dias a $15{ }^{\circ} \mathrm{C}$. Ao término deste procedimento, as amostras de arroz foram, então, submetidas à pesquisa de fumonisinas (ROSS et al., 1991 - adaptado).

\subsubsection{Extração e Purificação de Fumonisinas das Cepas Isoladas}

Após o crescimento das cepas isoladas em meio de arroz, $20 \mathrm{~mL}$ de metanol:água (3:1, $\mathrm{v} / \mathrm{v}$ ) foram adicionados ao tubo cônico de $50 \mathrm{~mL}$ contendo $10 \mathrm{~g}$ do produto da cultura, com 
posterior agitação por 45 minutos em agitador mecânico horizontal, filtragem em papel de filtro (Whatman $\mathrm{n}^{\circ}$ 4) e o $\mathrm{pH}$ corrigido para 5,8 a 6,5 com $\mathrm{NaOH}(1 \mathrm{~N})$. Uma alíquota de $2 \mathrm{~mL}$ do extrato foi passada em uma minicoluna contendo $500 \mathrm{mg}$ de sílica de troca-iônica (500 $\mathrm{mg} / 10 \mathrm{~mL}$ - BondElut SAX, Varian), a qual foi previamente condicionada com $5 \mathrm{~mL}$ de metanol e $5 \mathrm{~mL}$ de metanol:água $(3: 1, \mathrm{v} / \mathrm{v})$ em um fluxo de $1 \mathrm{~mL} / \mathrm{min}$ controlado pelo aparelho VAC-ELUT (Varian) acoplado à bomba a vácuo (Olidef-CZ). Após a passagem de 2 $\mathrm{mL}$ do extrato, $5 \mathrm{~mL}$ de metanol:água $(3: 1$, v/v) e $3 \mathrm{~mL}$ de metanol foram aplicados à coluna em fluxo de $1 \mathrm{~mL} / \mathrm{min}$. As fumonisinas foram eluídas com $5 \mathrm{~mL}$ de metanol:ácido acético (99:1, v/v) em fluxo de $1 \mathrm{~mL} / \mathrm{min}$. Finalmente, o produto da eluição foi evaporado até resíduo em banho-maria sob nitrogênio e mantido a $-4^{\circ} \mathrm{C}$ até o momento da detecção e quantificação (SYDENHAM et al., 1996 - adaptado).

\subsubsection{Cromatografia Líquida de Alta Eficiência- CLAE}

A análise cromatográfica foi realizada conforme metodologia descrita no item 3.6.6.2.

\subsection{Análise dos Fatores Climatológicos das Regiões}

Dados referentes à temperatura mínima e máxima $\left({ }^{\circ} \mathrm{C}\right)$ e à quantidade de chuvas por metro quadrado (índice pluviométrico - $\mathrm{mm}$ ) das duas regiões durante todo o período do experimento (outubro/2010 a março/2012) foram coletados diariamente em Estações Meteorológicas automatizadas próximas aos locais dos experimentos $(500 \mathrm{~m})$, sob a responsabilidade do Instituto Agronômico de Campinas (IAC).

\subsection{Análise Estatística}

O trabalho foi conduzido para estudar o efeito da rotação de culturas no isolamento de $F$. verticillioides e na detecção de $\mathrm{FB}_{1}$ e $\mathrm{FB}_{2}$ em grãos de milho. Para isso, nos dois diferentes municípios (Palmital e Capão Bonito), efetuou-se a rotação de culturas obedecendo aos 4 diferentes tratamentos. Para a análise estatística, foram considerados os resultados referentes à coleta das amostras de milho da safra verão 2011/2012 e da cobertura morta que antecedeu esta coleta, pois o principal objetivo do trabalho foi estudar o efeito da rotação de culturas quando os três ciclos já haviam sido completados. 
As análises estatísticas deste trabalho foram feitas utilizando-se os softwares R 2.9 pacote Gamlss e SAS 9.1 (RIGBY; STASINOPOULOS, 2005). 


\section{FLUXOGRAMA}

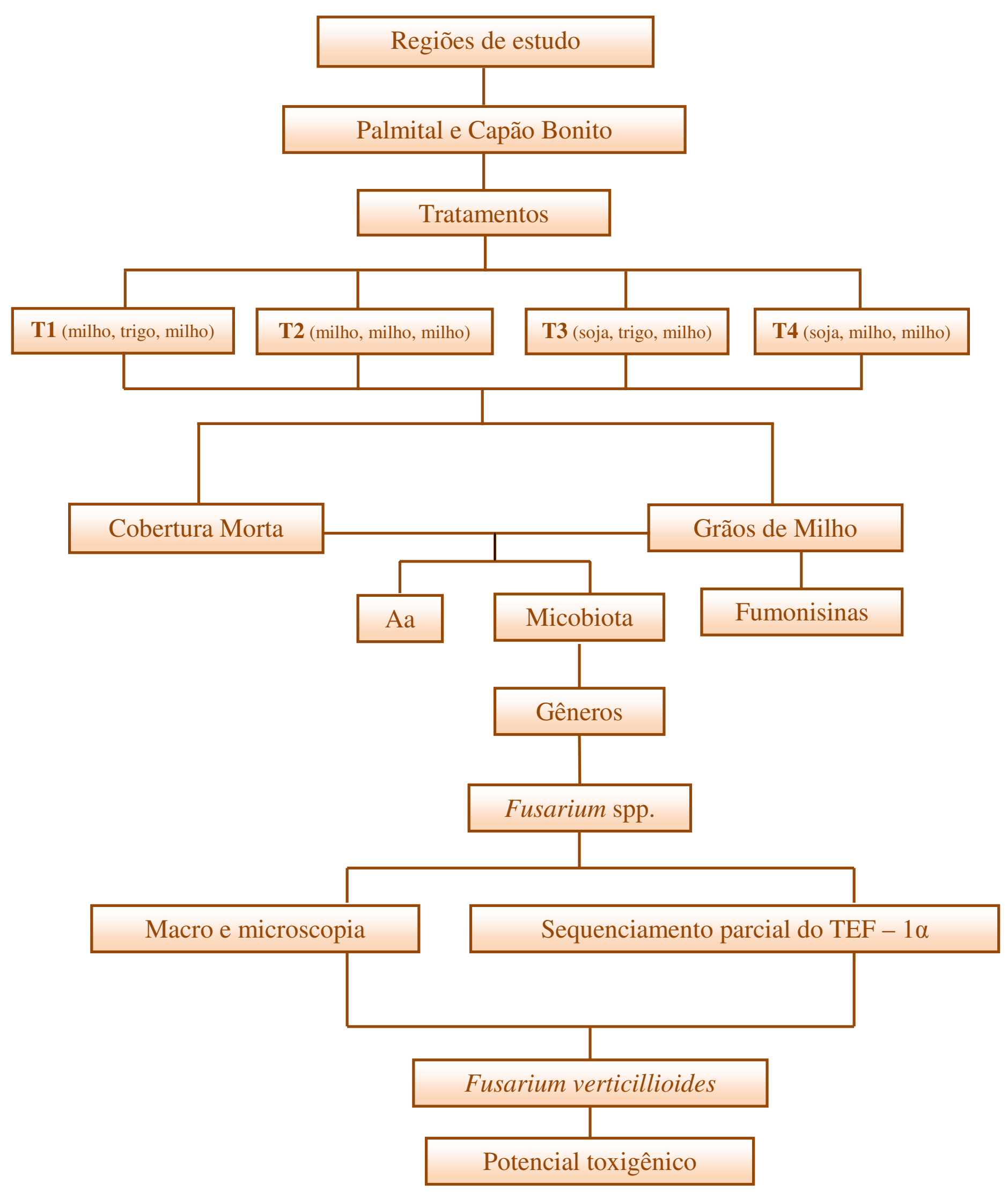




\section{RESULTADOS}

\subsection{Micobiota e Atividade de água (Aa)}

Foram realizadas a pesquisa de fungos (micobiota) e a determinação da Aa em 64 amostras de cobertura morta (32 por região, divididas em duas coletas) e em 144 de milho (72 por região, divididas em duas coletas). Todas as coletas foram feitas dentro dos períodos estipulados, porém, a coleta do milho safrinha (safra outono-inverno/2011) foi completamente comprometida devido à geada que atingiu as duas regiões.

\subsubsection{Cobertura Morta de PALMITAL}

5.1.1.1 $1^{a}$ coleta (realizada em outubro/2010, antes do plantio do milho safra verão 2010/2011)

Das 16 amostras coletadas, foram isolados os seguintes fungos, em ordem decrescente de frequência e de Unidades Formadoras de Colônias por grama de substrato (UFC/g) (Tabela 6):

- $\mathbf{T 1}$ - Cladosporium spp. (63,3\% - $\left.77 \times 10^{4} \mathrm{UFC} / \mathrm{g}\right)$, F. andiyazi $\left(12,4 \%-15 \times 10^{4}\right.$ UFC/g), Penicillium spp. (10,7\% - $\left.13 \times 10^{4} \mathrm{UFC} / \mathrm{g}\right)$, F. bulbicola $\left(5,8 \%-7 \times 10^{4}\right.$ $\mathrm{UFC} / \mathrm{g})$, Alternaria spp. $\left(5,0 \%-6 \times 10^{4} \mathrm{UFC} / \mathrm{g}\right)$ e $F$. verticillioides $\left(2,5 \%-3 \times 10^{4}\right.$ $\mathrm{UFC} / \mathrm{g})$;

- $\mathbf{T} 2$ - F. verticillioides $\left(33,1 \%-82 \times 10^{4} \mathrm{UFC} / \mathrm{g}\right)$, F. bulbicola $\left(30,2 \%-75 \times 10^{4}\right.$ UFC/g), Cladosporium spp. (13,2\% - 33 x 10 4 UFC/g), Aspergillus spp. (12,4\% - 31 x $\left.10^{4} \mathrm{UFC} / \mathrm{g}\right)$ e Penicillium spp. (10,8\% - $\left.27 \times 10^{4} \mathrm{UFC} / \mathrm{g}\right)$;

- $\quad$ T3 - Penicillium spp. (46,0\% - 29 x $\left.10^{4} \mathrm{UFC} / \mathrm{g}\right)$, Cladosporium spp. $\left(28,6 \%\right.$ - $18 \times 10^{4}$ $\mathrm{UFC} / \mathrm{g}), F$. verticillioides $\left(9,5 \%-6 \times 10^{4} \mathrm{UFC} / \mathrm{g}\right), \mathrm{F}$. bulbicola $\left(6,3 \%-4 \times 10^{4}\right.$ $\mathrm{UFC} / \mathrm{g}), F$. andiyazi $\left(4,8 \%-3 \times 10^{4} \mathrm{UFC} / \mathrm{g}\right)$ e F. semitectum $\left(4,8 \%-3 \times 10^{4} \mathrm{UFC} / \mathrm{g}\right)$;

- $\mathbf{T} 4$ - Cladosporium spp. (46,0\% - $\left.173 \times 10^{4} \mathrm{UFC} / \mathrm{g}\right)$, F. verticillioides $(22,9 \%-86 \times$ $\left.10^{4} \mathrm{UFC} / \mathrm{g}\right)$, Mucor spp. $\left(15,9 \%-60 \times 10^{4} \mathrm{UFC} / \mathrm{g}\right)$, Penicillium spp. $\left(9,3 \%-35 \times 10^{4}\right.$ $\mathrm{UFC} / \mathrm{g}), F$. graminearum $\left(2,7 \%-10 \times 10^{4} \mathrm{UFC} / \mathrm{g}\right), F$. oxysporum $\left(1,6 \%-6 \times 10^{4}\right.$ UFC/g) e Trichoderma spp. (1,6\%- $\left.6 \times 10^{4} \mathrm{UFC} / \mathrm{g}\right)$. 
Em relação à Aa, o valor médio encontrado foi de 0,78 (Tabela 6).

Tabela 6 - Frequência de isolamento fúngico (\%), número de UFC/g (Unidades Formadoras de Colônias por grama de substrato) e atividade de água (Aa) média das amostras de Cobertura Morta - $1^{\text {a }}$ coleta de Palmital (outubro/2010).

\begin{tabular}{|c|c|c|c|c|c|c|c|c|}
\hline \multirow{2}{*}{ Fungos } & \multicolumn{2}{|r|}{$\mathrm{T} 1 *$} & \multicolumn{2}{|r|}{$\mathbf{T} 2 * *$} & \multicolumn{2}{|c|}{$\mathrm{T} 3 * * * *$} & \multicolumn{2}{|r|}{$\mathrm{T} 4 * * * * *$} \\
\hline & $\%$ & $\mathrm{UFC} / \mathrm{g}$ & $\%$ & $\mathrm{UFC} / \mathrm{g}$ & $\%$ & $\mathrm{UFC} / \mathrm{g}$ & $\%$ & UFC/g \\
\hline F. verticillioides & 2,5 & $3,0 \times 10^{4}$ & 33,1 & $82,0 \times 10^{4}$ & 9,5 & $6,0 \times 10^{4}$ & 22,9 & $86,0 \times 10^{4}$ \\
\hline$F$. andiyazi & 12,4 & $15,0 \times 10^{4}$ & - & - & 4,8 & $3,0 \times 10^{4}$ & - & - \\
\hline F. bulbicola & 5,8 & $7,0 \times 10^{4}$ & 30,2 & $75,0 \times 10^{4}$ & 6,3 & $4,0 \times 10^{4}$ & - & - \\
\hline F. semitectum & - & - & - & - & 4,8 & $3,0 \times 10^{4}$ & - & - \\
\hline F. graminearum & - & - & - & - & - & - & 2,7 & $10,0 \times 10^{4}$ \\
\hline F. oxysporum & - & - & - & - & - & - & 1,6 & $6,0 \times 10^{4}$ \\
\hline Cladosporium spp. & 63,3 & $77,0 \times 10^{4}$ & 13,2 & $33,0 \times 10^{4}$ & 28,6 & $18,0 \times 10^{4}$ & 46,0 & $173,0 \times 10^{4}$ \\
\hline Alternaria spp. & 5,0 & $6,0 \times 10^{4}$ & - & - & , & - & - & - \\
\hline Penicillium spp. & 10,7 & $13,0 \times 10^{4}$ & 10,8 & $27,0 \times 10^{4}$ & 46,0 & $29,0 \times 10^{4}$ & 9,3 & $35,0 \times 10^{4}$ \\
\hline Aspergillus spp. & - & - & 12,4 & $31,0 \times 10^{4}$ & , & - & - & - \\
\hline Mucor spp. & - & - & - & - & - & - & 15,9 & $60,0 \times 10^{4}$ \\
\hline Trichoderma spp. & - & - & - & - & - & - & 1,6 & $6,0 \times 10^{4}$ \\
\hline Aa média & & 0,77 & & 0,84 & & 0,75 & & 0,78 \\
\hline
\end{tabular}

*T1 ou Tratamento 1 :milho/trigo/milho; **T2 ou Tratamento 2: milho/milhosafrinha/milho; ***T3 ou Tratamento 3: soja/trigo/milho; ****T4 ou Tratamento 4: soja/milho safrinha/milho.

5.1.1.2 $2^{a}$ coleta (realizada em outubro/2011, antes do plantio do milho safra verão 2011/2012)

De 16 amostras, foram isolados os seguintes fungos, em ordem decrescente de frequência e de Unidades Formadoras de Colônias por grama de substrato (UFC/g) (Tabela 7):

- T1 - Cladosporium spp. (55,6\% - $\left.730 \times 10^{4} \mathrm{UFC} / \mathrm{g}\right)$, Penicillium spp. (22,3\% - $290 \mathrm{x}$ $\left.10^{4} \mathrm{UFC} / \mathrm{g}\right)$, F. verticillioides $\left(13,0 \%\right.$ - $\left.170 \times 10^{4} \mathrm{UFC} / \mathrm{g}\right)$, Trichoderma spp. (8,3\% $\left.110 \times 10^{4} \mathrm{UFC} / \mathrm{g}\right)$ e $F$. sacchari $\left(0,8 \%-10 \times 10^{4} \mathrm{UFC} / \mathrm{g}\right)$;

- $\quad$ T2 - Cladosporium spp. (88,6\% - $\left.543 \times 10^{4} \mathrm{UFC} / \mathrm{g}\right)$, Penicillium spp. (6,5\% - 39,4 x $\left.10^{4} \mathrm{UFC} / \mathrm{g}\right), \mathrm{F}$. verticillioides $\left(4,9 \%-30 \times 10^{4} \mathrm{UFC} / \mathrm{g}\right)$ e Trichoderma spp. $(0,3 \%-1,1$ x $\left.10^{4} \mathrm{UFC} / \mathrm{g}\right)$;

- $\quad$ T3 - Cladosporium spp. (43,1\% - 416 x 104 UFC/g), Penicillium spp. (37,7\% - 364 x $\left.10^{4} \mathrm{UFC/g}\right)$, Trichoderma spp. (12,4\% - $\left.120 \times 10^{4} \mathrm{UFC} / \mathrm{g}\right), \mathrm{F}$. proliferatum $(3,1 \%-30$ 
x $\left.10^{4} \mathrm{UFC} / \mathrm{g}\right), F$. bulbicola $\left(3,1 \%-30 \times 10^{4} \mathrm{UFC} / \mathrm{g}\right)$ e $F$. verticillioides $(0,6 \%-5 \mathrm{x}$ $\left.10^{4} \mathrm{UFC} / \mathrm{g}\right)$

- $\quad$ T4 - Cladosporium spp. (73,7\% - 1.040 x $\left.10^{4} \mathrm{UFC} / \mathrm{g}\right)$, Penicillium spp. (11,3\% - 160 x $\left.10^{4} \mathrm{UFC} / \mathrm{g}\right)$, Trichoderma spp. (7,8\% - $\left.110 \times 10^{4} \mathrm{UFC} / \mathrm{g}\right), \mathrm{F}$. verticillioides $(5,7 \%$ $\left.80 \times 10^{4} \mathrm{UFC} / \mathrm{g}\right)$ e $F$. subglutinans $\left(1,5 \%-20 \times 10^{4} \mathrm{UFC} / \mathrm{g}\right)$.

Em relação à Aa, o valor médio foi de 0,46 (Tabela 7).

Tabela 7 - Frequência de isolamento fúngico (\%), número de UFC/g (Unidades Formadoras de Colônias por grama de substrato) e atividade de água (Aa) média das amostras de Cobertura Morta - $2^{a}$ coleta de Palmital (outubro/2011).

\begin{tabular}{|c|c|c|c|c|c|c|c|c|}
\hline \multirow{2}{*}{ Fungos } & \multicolumn{2}{|r|}{$\mathbf{T} 1 *$} & \multicolumn{2}{|r|}{$\mathrm{T} 2 * *$} & \multicolumn{2}{|r|}{$\mathrm{T} 3 * * * *$} & \multicolumn{2}{|r|}{$\mathrm{T} 4 * * * * *$} \\
\hline & $\%$ & UFC/g & $\%$ & UFC/g & $\%$ & $\mathrm{UFC} / \mathrm{g}$ & $\%$ & UFC/g \\
\hline F. verticillioides & 13,0 & $170,0 \times 10^{4}$ & 4,9 & $30,0 \times 10^{4}$ & 0,6 & $5,0 \times 10^{4}$ & 5,7 & $80,0 \times 10^{4}$ \\
\hline F. sacchari & 0,8 & $10,0 \times 10^{4}$ & - & - & - & - & - & - \\
\hline F. proliferatum & - & - & - & - & 3,1 & $30,0 \times 10^{4}$ & - & - \\
\hline F. bulbicola & - & - & - & - & 3,1 & $30,0 \times 10^{4}$ & - & - \\
\hline F. subglutinans & - & - & - & - & - & - & 1,5 & $20,0 \times 10^{4}$ \\
\hline Cladosporium spp. & 55,6 & $730,0 \times 10^{4}$ & 88,5 & $543,0 \times 10^{4}$ & 43,1 & $416,0 \times 10^{4}$ & 73,7 & $1.040,0 \times 10^{4}$ \\
\hline Penicillium spp. & 22,3 & $290,0 \times 10^{4}$ & 6,4 & $39,4 \times 10^{4}$ & 37,7 & $364,0 \times 10^{4}$ & 11,3 & $160,0 \times 10^{4}$ \\
\hline Trichoderma spp. & 8,3 & $110,0 \times 10^{4}$ & 0,2 & $1,1 \times 10^{4}$ & 12,4 & $120,0 \times 10^{4}$ & 7,8 & $110,0 \times 10^{4}$ \\
\hline Aa média & & 0,45 & & 0,47 & & 0,46 & & 0,47 \\
\hline
\end{tabular}

*T1 ou Tratamento 1 :milho/trigo/milho; **T2 ou Tratamento 2: milho/milho safrinha/milho; ***T3 ou Tratamento 3: soja/trigo/milho; ****T4 ou Tratamento 4: soja/milho safrinha/milho.

\subsubsection{Milho de PALMITAL}

\subsubsection{1 $1^{a}$ coleta (safra verão 2010/2011, coletada em fevereiro/2011)}

Das 16 parcelas a campo, 8 foram plantadas com milho. As outras 8 parcelas (T3 e T4) continham soja. Foram coletadas 3 amostras por parcela plantada com milho, totalizando 24 amostras de milho recém-colhido. Destas, foram isolados os seguintes fungos, em ordem decrescente de frequência (Tabela 8):

- T1: F. verticillioides - 34,4\%; Acremonium spp. - 19,9\%; Penicillium spp. - 8,8\%; F. bulbicola - 4,6\%; Aspergillus spp. - 2,5\%; Cladosporium spp. - 2,3\%; F. andiyazi$2,0 \% ; F$. proliferatum - 2,0\%; F. graminearum - 0,2\%; 
- T2: F. verticillioides - 42,9\%; Penicillium spp. - 12,6\%; Acremonium spp. - 9,1\%; F. andiyazi - 5,3\%; Aspergillus spp. - 1,8\%; Trichoderma spp. - 1,3\%; F. semitectum1,3\%; Cladosporium spp. - 0,5\%; F. incarnatum - 0,2\%.

O valor médio registrado da Aa foi de 0,90 (Tabela 8).

Tabela 8 - Frequência de isolamento fúngico (\%) e atividade de água (Aa) média das amostras de Grãos de Milho - $1^{a}$ coleta (safra verão 2010/2011) na região de Palmital.

\begin{tabular}{ccc}
\hline Fungos & T1* & T2*** \\
\hline F. verticillioides & $\mathbf{3 4 , 4 \%}$ & $\mathbf{4 2 , 9 \%}$ \\
F. proliferatum & $2,0 \%$ & - \\
F. andiyazi & $2,0 \%$ & $5,3 \%$ \\
F. bulbicola & $4,6 \%$ & - \\
F. graminearum & $0,2 \%$ & - \\
F. semitectum & - & $1,3 \%$ \\
F. incarnatum & - & $0,2 \%$ \\
Penicillium spp. & $8,8 \%$ & $12,6 \%$ \\
Aspergillus spp. & $2,5 \%$ & $1,8 \%$ \\
Acremonium spp. & $19,9 \%$ & $9,1 \%$ \\
Cladosporium spp. & $2,3 \%$ & $0,5 \%$ \\
Trichoderma spp. & - & $1,3 \%$ \\
\hline Aa média & 0,90 & 0,90 \\
\hline
\end{tabular}

*T1 ou Tratamento 1 :milho/trigo/milho; **T2 ou Tratamento 2: milho/milho safrinha/milho.

5.1.2.2 Segunda e Última coleta (safra verão 2011/2012, coletada em fevereiro/2012)

Das 16 parcelas a campo plantadas com milho, foram coletadas 3 amostras por parcela, totalizando 48 amostras de milho recém-colhido. Destas, foram isolados os seguintes fungos em ordem decrescente de frequência (Tabela 9):

- T1: F. verticillioides - 69,2\%; F. proliferatum - 5,3\%; Trichoderma spp. - 3,1\%; Aspergillus spp. - 2,8\%; Penicillium spp. - 1,6\%; Rhizopus spp. - 1,0\%; Cladosporium spp. $-0,8 \%$.

- T2: F. verticillioides - 81,8\%; Cladosporium spp. - 6,3\%; Aspergillus spp. - 2,5\%; Trichoderma spp. - 2,3\%; Rhizopus spp. - 1,5\%; Penicillium spp. - 0,2\%.

- T3: F. verticillioides - 73,7\%; F. proliferatum - 6,1\%; Acremonium spp. - 5,8\%; Penicillium spp. - 2,5\%; Aspergillus spp. - 2,0\%; Neorospora spp. - 1,0\%; 
Nigrospora spp. - 0,7\%; Trichoderma spp. - 0,5\%; Rhizopus spp. - 0,2\%; Cladosporium spp. $-0,2 \%$.

- T4: F. verticillioides - 56,4\%; F. andiyazi - 15,9\%; F. graminearum - 10,1\%; F. proliferatum - 8,3\%; Cladosporium spp. - 4,6\%; Trichoderma spp. - 0,8\%; Rhizopus spp. - 0,5\%; Penicillium spp. - 0,5\%; Aspergillus spp. - 0,2\%.

O valor médio registrado da Aa foi de 0,92 (Tabela 9).

Tabela 9 - Frequência de isolamento fúngico (\%) e atividade de água (Aa) média das amostras de Grãos de Milho - última coleta (safra verão 2011/2012) na região de Palmital.

\begin{tabular}{ccccc}
\hline Fungos & $\mathbf{T 1}$ & $\mathbf{T 2} * *$ & $\mathbf{T 3} * * *$ & $\mathbf{T 4} * * * *$ \\
\hline F. verticillioides & $\mathbf{6 9 , 2 \%}$ & $\mathbf{8 1 , 8 \%}$ & $\mathbf{7 3 , 7 \%}$ & $\mathbf{5 6 , 4 \%}$ \\
F. proliferatum & $5,3 \%$ & - & $6,1 \%$ & $8,3 \%$ \\
F. graminearum & - & - & - & $10,1 \%$ \\
F. andiyazi & - & - & - & $15,9 \%$ \\
Penicillium spp. & $1,6 \%$ & - & $2,5 \%$ & $0,5 \%$ \\
Aspergillus spp. & $2,8 \%$ & $2,5 \%$ & $2,0 \%$ & $0,2 \%$ \\
Acremonium spp. & - & - & $5,8 \%$ & - \\
Cladosporium spp. & $0,8 \%$ & $6,3 \%$ & $0,2 \%$ & $4,6 \%$ \\
Trichoderma spp. & $3,1 \%$ & $2,3 \%$ & $0,5 \%$ & $0,8 \%$ \\
Rhizopus spp. & $1,0 \%$ & $1,5 \%$ & $0,2 \%$ & $0,2 \%$ \\
Nigrospora spp. & - & - & $0,7 \%$ & - \\
Neorospora spp. & - & - & $1,0 \%$ & - \\
\hline Aa média & 0,93 & 0,92 & 0,93 & 0,91 \\
\hline
\end{tabular}

*T1 ou Tratamento 1 :milho/trigo/milho; **T2 ou Tratamento 2: milho/milho safrinha/milho; ***T3 ou

Tratamento 3: soja/trigo/milho; ****T4 ou Tratamento 4: soja/milho safrinha/milho.

\subsubsection{Cobertura Morta de CAPÃO BONITO}

5.1.3.1 $1^{a}$ coleta (realizada em outubro/2010, antes do plantio do milho safra verão 2010/2011)

Das 16 amostras de cobertura morta coletadas na região de Capão Bonito, foram isolados os seguintes fungos em ordem decrescente de frequência e de Unidades Formadoras de Colônias por grama de substrato (UFC/g) (Tabela 10): 
- $\quad$ T1 - Cladosporium spp. (92,4\% - 27,8 x 104 UFC/g), Nigrospora spp. (3,3\% - 1,0 x $\left.10^{4} \mathrm{UFC} / \mathrm{g}\right), F$. poae $\left(3,3 \%-1,0 \times 10^{4} \mathrm{UFC} / \mathrm{g}\right), F$. andiyazi $\left(0,7 \%-0,2 \times 10^{4} \mathrm{UFC} / \mathrm{g}\right) \mathrm{e}$ Alternaria spp. (0,3\% - 0,1 x $\left.10^{4} \mathrm{UFC} / \mathrm{g}\right)$;

- $\mathbf{T} 2$ - Cladosporium spp. (50,1\% - 180,4 x $\left.10^{4} \mathrm{UFC} / \mathrm{g}\right)$, F. incarnatum $(36,1 \%-130 \mathrm{x}$ $\left.10^{4} \mathrm{UFC} / \mathrm{g}\right)$, F. bulbicola $\left(10,5 \%-37,7 \times 10^{4} \mathrm{UFC} / \mathrm{g}\right)$, Alternaria spp. $(2,8 \%-10,2 \mathrm{x}$ $\left.10^{4} \mathrm{UFC} / \mathrm{g}\right)$ e Aspergillus spp. (0,5\% - 2,0 x $\left.10^{4} \mathrm{UFC} / \mathrm{g}\right)$;

- $\quad$ T3 - Cladosporium spp. (49,5\% - $\left.96 \times 10^{4} \mathrm{UFC} / \mathrm{g}\right)$, F. bulbicola $\left(35,1 \%\right.$ - $68 \times 10^{4}$ $\mathrm{UFC} / \mathrm{g})$ e F. semitectum $\left(15,4 \%-30 \times 10^{4} \mathrm{UFC} / \mathrm{g}\right)$;

- $\mathbf{T} 4$ - F. bulbicola $\left(52,9 \%\right.$ - $\left.57 \times 10^{4} \mathrm{UFC} / \mathrm{g}\right)$, Cladosporium spp. $\left(41,7 \%\right.$ - $45 \times 10^{4}$ $\mathrm{UFC} / \mathrm{g}), F$. graminearum $\left(1,8 \%-2 \times 10^{4} \mathrm{UFC} / \mathrm{g}\right)$, Rhizopus spp. $\left(1,8 \%-2 \times 10^{4}\right.$ UFC/g), Alternaria spp. (0,9\% - $\left.1 \times 10^{4} \mathrm{UFC} / \mathrm{g}\right)$ e Aspergillus spp. $\left(0,9 \%-1 \times 10^{4}\right.$ $\mathrm{UFC} / \mathrm{g})$.

Em relação à Aa, o valor médio foi de 0,49 (Tabela 10).

Tabela 10 - Frequência de isolamento fúngico (\%), número de UFC/g (Unidades Formadoras de Colônias por grama de substrato) e atividade de água (Aa) média das amostras de Cobertura Morta - $1^{a}$ coleta de Capão Bonito (outubro/2010).

\begin{tabular}{|c|c|c|c|c|c|c|c|c|}
\hline \multirow{2}{*}{ Fungos } & \multicolumn{2}{|r|}{ T1* } & \multicolumn{2}{|r|}{$\mathrm{T} 2 * *$} & \multicolumn{2}{|c|}{$\mathrm{T} 3 * * * *$} & \multicolumn{2}{|c|}{$\mathrm{T} 4 * * * * * *$} \\
\hline & $\%$ & UFC/g & $\%$ & UFC/g & $\%$ & UFC/g & $\%$ & UFC/g \\
\hline F. poae & 3,3 & $1,0 \times 10^{4}$ & - & - & - & - & - & - \\
\hline$F$. andiyazi & 0,7 & $0,2 \times 10^{4}$ & - & - & - & - & - & - \\
\hline F. incarnatum & - & - & 36,1 & $130,0 \times 10^{4}$ & - & - & - & - \\
\hline F. bulbicola & - & - & 10,5 & $37,7 \times 10^{4}$ & 35,1 & $68,0 \times 10^{4}$ & 52,9 & $57,0 \times 10^{4}$ \\
\hline F. semitectum & - & - & - & - & 15,4 & $30,0 \times 10^{4}$ & - & - \\
\hline F. graminearum & - & - & - & - & - & - & 1,8 & $2,0 \times 10^{4}$ \\
\hline Cladosporium spp. & 92,4 & $27,8 \times 10^{4}$ & 50,1 & $180,4 \times 10^{4}$ & 49,5 & $96,0 \times 10^{4}$ & 41,7 & $45,0 \times 10^{4}$ \\
\hline Alternaria spp. & 0,3 & $0,1 \times 10^{4}$ & 2,8 & $10,2 \times 10^{4}$ & - & - & 0,9 & $1,0 \times 10^{4}$ \\
\hline Rhizopus spp. & - & - & - & - & - & - & 1,8 & $2,0 \times 10^{4}$ \\
\hline Aspergillus spp. & - & - & 0,5 & $2,0 \times 10^{4}$ & - & - & 0,9 & $1,0 \times 10^{4}$ \\
\hline Nigrospora spp. & 3,3 & $1,0 \times 10^{4}$ & - & - & - & - & - & - \\
\hline Aa média & & 0,46 & & 0,54 & & 0,48 & & 0,50 \\
\hline
\end{tabular}

*T1 ou Tratamento 1 :milho/trigo/milho; **T2 ou Tratamento 2: milho/milho safrinha/milho; ***T3 ou Tratamento 3: soja/trigo/milho; ****T4 ou Tratamento 4: soja/milho safrinha/milho. 
5.1.3.2 $2^{a}$ coleta (realizada em setembro/2011, antes do plantio do milho safra verão 2011/2012)

Das 16 amostras coletadas, foram isolados os seguintes fungos em ordem decrescente de frequência e de Unidades Formadoras de Colônias por grama de substrato (UFC/g) (Tabela 11):

- $\quad$ T1 - Cladosporium spp. (77,6\% - $\left.1.110 \times 10^{4} \mathrm{UFC} / \mathrm{g}\right)$, Penicillium spp. (9,8\% - $140 \mathrm{x}$ $\left.10^{4} \mathrm{UFC} / \mathrm{g}\right)$, F. graminearum $\left(7,7 \%\right.$ - $\left.110 \times 10^{4} \mathrm{UFC} / \mathrm{g}\right)$ e Trichoderma spp. (4,9\% $\left.70 \times 10^{4} \mathrm{UFC} / \mathrm{g}\right)$;

- $\quad$ T2 - Cladosporium spp. (87,3\% - $\left.760 \times 10^{4} \mathrm{UFC} / \mathrm{g}\right)$, Trichoderma spp. (4,6\% - $40 \mathrm{x}$ $\left.10^{4} \mathrm{UFC} / \mathrm{g}\right)$, F. graminearum $\left(3,5 \%-30 \times 10^{4} \mathrm{UFC} / \mathrm{g}\right)$, Aspergillus spp. $(3,5 \%-30 \mathrm{x}$ $\left.10^{4} \mathrm{UFC} / \mathrm{g}\right)$ e Penicillium spp. $\left(1,1 \%-10 \times 10^{4} \mathrm{UFC} / \mathrm{g}\right)$;

- $\quad$ T3 - Cladosporium spp. (87,7\% - $\left.1.260 \times 10^{4} \mathrm{UFC} / \mathrm{g}\right)$, Trichoderma spp. (10,6\% - 150 x $\left.10^{4} \mathrm{UFC} / \mathrm{g}\right)$ e $F$. graminearum $\left(0,7 \%-10 \times 10^{4} \mathrm{UFC} / \mathrm{g}\right)$;

- T4 - Cladosporium spp. (78,9\% - $\left.670 \times 10^{4} \mathrm{UFC} / \mathrm{g}\right)$, Trichoderma spp. (9,4\% - $80 \mathrm{x}$ $\left.10^{4} \mathrm{UFC} / \mathrm{g}\right), F$. verticillioides $\left(7,1 \%-60 \times 10^{4} \mathrm{UFC} / \mathrm{g}\right), F$. subglutinans $(2,3 \%-20 \mathrm{x}$ $\left.10^{4} \mathrm{UFC} / \mathrm{g}\right)$ e $F$. graminearum $\left(2,3 \%-20 \times 10^{4} \mathrm{UFC} / \mathrm{g}\right)$.

Em relação à Aa, o valor médio foi de 0,48 (Tabela 11).

Tabela 11 - Frequência de isolamento fúngico (\%), número de UFC/g (Unidades Formadoras de Colônias por grama de substrato) e atividade de água (Aa) média das amostras de Cobertura Morta - $2^{\text {a }}$ coleta de Capão Bonito (setembro/2011).

\begin{tabular}{|c|c|c|c|c|c|c|c|c|}
\hline \multirow{2}{*}{ Fungos } & \multicolumn{2}{|r|}{$\mathrm{T} 1 *$} & \multicolumn{2}{|r|}{$\mathrm{T} 2 * * *$} & \multicolumn{2}{|r|}{$\mathrm{T} 3 * * * *$} & \multicolumn{2}{|c|}{$\mathrm{T} 4 * * * * *$} \\
\hline & $\%$ & UFC/g & $\%$ & UFC/g & $\%$ & UFC/g & $\%$ & UFC/g \\
\hline F. verticillioides & - & - & - & - & - & - & 7,1 & $60,0 \times 10^{4}$ \\
\hline F. graminearum & 7,7 & $110,0 \times 10^{4}$ & 3,5 & $30,0 \times 10^{4}$ & 0,7 & $10,0 \times 10^{4}$ & 2,3 & $20,0 \times 10^{4}$ \\
\hline F. subglutinans & - & - & - & - & - & - & 2,3 & $20,0 \times 10^{4}$ \\
\hline Cladosporium sp. & 77,6 & $1110,0 \times 10^{4}$ & 87,3 & $760,0 \times 10^{4}$ & 87,7 & $1260,0 \times 10^{4}$ & 78,9 & $670,0 \times 10^{4}$ \\
\hline Penicillium sp. & 9,8 & $140,0 \times 10^{4}$ & 1,1 & $10,0 \times 10^{4}$ & - & - & - & - \\
\hline Trichoderma sp. & 4,9 & $70,0 \times 10^{4}$ & 4,6 & $40,0 \times 10^{4}$ & 10,6 & $150,0 \times 10^{4}$ & 9,4 & $80,0 \times 10^{4}$ \\
\hline Aspergillus sp. & - & - & 3,5 & $30,0 \times 10^{4}$ & - & - & - & - \\
\hline Aa média & & 0,49 & & 0,47 & & 0,47 & & 0,49 \\
\hline
\end{tabular}

*T1 ou Tratamento 1 :milho/trigo/milho; **T2 ou Tratamento 2: milho/milho safrinha/milho; ***T3 ou Tratamento 3: soja/trigo/milho; ****T4 ou Tratamento 4: soja/milho safrinha/milho. 


\subsubsection{Milho de CAPÃO BONITO}

5.1.4.1 $1^{a}$ coleta (safra verão 2010/2011, coletada em março/2011)

Das 16 parcelas à campo, 8 foram plantadas com milho. As outras 8 parcelas (T3 e T4) continham soja. Foram coletadas 3 amostras/parcela plantada com milho, totalizando 24 amostras de milho recém-colhido. Destas, foram isolados os seguintes fungos em ordem decrescente de frequência (Tabela 12):

- T1: F. verticillioides - 31,1\%; Acremonium spp. - 15,9\%; F. bulbicola - 9,6\%; Penicillium spp. - 4,3\%; F. subglutinans - 3,8\%; Trichoderma spp. - 2,3\%; F. proliferatum - 1,8\%; F. semitectum - 0,5\%; Aspergillus spp. - 0,5\%; Cladosporium spp. $-0,5 \% ;$ F. oxysporum $-0,2 \%$;

- T2: F. verticillioides - 30,1\%; Acremonium spp. - 10,6\%; Neorospora spp. - 10,6\%; Penicillium spp. - 7,8\%; F. bulbicola - 3,8\%; Cladosporium spp. - 3,5\%; F. oxysporum - 2,3\%; F. graminearum - 1,0\%; Trichoderma spp. - 1,0\%; Aspergillus spp. $-0,7 \%$.

O valor médio registrado da Aa foi de 0,94 (Tabela 12).

Tabela 12 - Frequência de isolamento fúngico (\%) e atividade de água (Aa) média das amostras de Grãos de Milho - $1^{\text {a }}$ coleta (safra verão 2010/2011) em Capão Bonito.

\begin{tabular}{ccc}
\hline Fungos & T1* & T2*** \\
\hline F. verticillioides & $\mathbf{3 1 , 1 \%}$ & $\mathbf{3 0 , 1 \%}$ \\
F. semitectum & $0,5 \%$ & - \\
F. bulbicola & $9,6 \%$ & $3,8 \%$ \\
F. oxysporum & $0,2 \%$ & $2,3 \%$ \\
F. proliferatum & $1,8 \%$ & - \\
F. subglutinans & $3,8 \%$ & - \\
F. andiyazi & - & $0,7 \%$ \\
F. graminearum & - & $1,0 \%$ \\
Penicillium spp. & $4,3 \%$ & $7,8 \%$ \\
Aspergillus spp. & $0,5 \%$ & $0,7 \%$ \\
Acremonium spp. & $15,9 \%$ & $10,6 \%$ \\
Cladosporium spp. & $0,5 \%$ & $3,5 \%$ \\
Trichoderma spp. & $2,3 \%$ & $1,0 \%$ \\
Neorospora spp. & - & $10,6 \%$ \\
\hline Aa média & 0,94 & 0,95 \\
\hline
\end{tabular}

\footnotetext{
*T1 ou Tratamento 1 :milho/trigo/milho; **T2 ou Tratamento 2: milho/milho safrinha/milho.
} 
5.1.4.2 $2^{a}$ e ultima coleta (safra verão 2011/2012, realizada em março/2012)

Das 16 parcelas a campo plantadas com milho, foram coletadas 3 amostras/parcela, totalizando 48 amostras de milho recém-colhido. Destas, foram isolados os seguintes fungos em ordem decrescente de frequência (Tabela 13):

- T1: F. verticillioides - 81,8\%; Penicillium spp. - 28,3\%; Rhizopus spp. - 8,3\%; F. bulbicola-2,8\%; Aspergillus spp. - 2,8\%; Cladosporium spp. - 2,8\%; Trichoderma spp. $-1,5 \%$.

- T2: F. verticillioides - 71,7\%; Penicillium spp. - 18,7\%; F. semitectum - 7,6\%; F. bulbicola - 7,3\%; Trichoderma spp. - 3,5\%; Aspergillus spp. -3,3\%; Rhizopus spp. $1,8 \%$; Cladosporium spp. $-1,3 \%$.

- T3: F. verticillioides - 58,8\%; Penicillium spp. - 18,4\%; F. bulbicola - 14,4\%; Cladosporium spp. - 10,1\%; F. graminearum - 7,8\%; Rhizopus spp. - 1,8\%; Aspergillus spp. - 0,5\%; Trichoderma spp. - 0,2\%.

- T4: F. verticillioides - 64,4\%; Penicillium spp. - 16,4\%; F. graminearum - 8,1\%; F. bulbicola $-6,6 \% ;$ F. proliferatum $-5,3 \% ;$ Cladosporium spp. - 2,5\%; F. semitectum 2,0\%; Rhizopus spp. - 1,8\%; Trichoderma spp. $-1,5 \%$.

O valor médio registrado da Aa foi de 0,97 (Tabela 13).

Tabela 13 - Frequência de isolamento fúngico (\%) e atividade de água (Aa) média das amostras de Grãos de Milho - última coleta (safra verão 2011/2012) na região de Capão Bonito.

\begin{tabular}{ccccc}
\hline Fungos & T1* & T2*** & T3**** & T4***** \\
\hline F. verticillioides & $\mathbf{8 1 , 8 \%}$ & $\mathbf{7 1 , 7 \%}$ & $\mathbf{5 8 , 8 \%}$ & $\mathbf{6 4 , 4 \%}$ \\
F. bulbicola & $2,8 \%$ & $7,3 \%$ & $14,4 \%$ & $6,6 \%$ \\
F. semitectum & - & $7,6 \%$ & - & $2,0 \%$ \\
F. graminearum & - & - & $7,8 \%$ & $8,1 \%$ \\
F. proliferatum & - & - & - & $5,3 \%$ \\
Penicillium spp. & $28,3 \%$ & $18,7 \%$ & $18,4 \%$ & $16,4 \%$ \\
Aspergillus spp. & $2,8 \%$ & $3,3 \%$ & $0,5 \%$ & - \\
Cladosporium spp. & $2,8 \%$ & $1,3 \%$ & $10,1 \%$ & $2,5 \%$ \\
Trichoderma spp. & $1,5 \%$ & $3,5 \%$ & $0,2 \%$ & $1,5 \%$ \\
Rhizopus spp. & $8,3 \%$ & $1,8 \%$ & $1,8 \%$ & $1,8 \%$ \\
\hline Aa média & 0,97 & 0,97 & 0,97 & 0,96 \\
\hline
\end{tabular}

*T1 ou Tratamento 1 :milho/trigo/milho; **T2 ou Tratamento 2: milho/milho safrinha/milho; ***T3 ou Tratamento 3: soja/trigo/milho; ****T4 ou Tratamento 4: soja/milho safrinha/milho. 


\subsection{Identificação das espécies do gênero Fusarium por metodologia clássica e molecular}

A identificação morfológica das 313 cepas de Fusarium spp. isoladas de amostras de cobertura morta e grãos de milho, nas duas regiões estudadas, foi realizada através da visualização das características macroscópicas e microscópicas.

Estes isolados também foram submetidos ao sequenciamento parcial do gene do fator de elongação $1 \alpha$.

Foram isoladas e identificadas onze diferentes espécies, entre elas: F. verticillioides (72,5\%), F. bulbicola (7,7\%), F. graminearum (6,1\%), F. andiyazi (4,2\%), F. semitectum $(2,9 \%), F$. proliferatum $(2,2 \%), F$. subglutinans $(1,6 \%), F$. oxysporum $(1,3 \%), F$. incarnatum $(0,9 \%), F$. poae $(0,3 \%)$ e $F$. sacchari $(0,3 \%)$ (Figura 20$)$.

Figura 20 - Espécies de Fusarium spp. identificadas em amostras de cobertura morta e de grãos de milho, nas duas regiões estudadas.

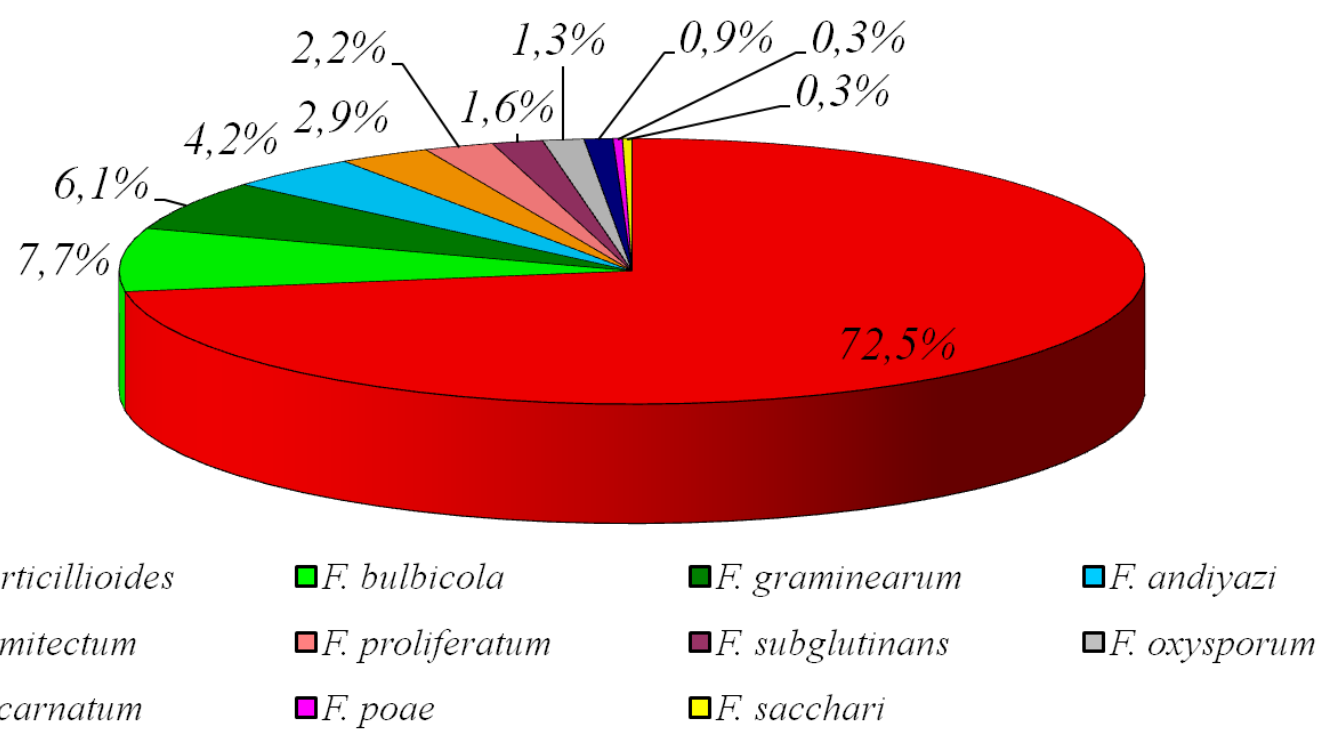

Do total das 227 cepas identificadas como $F$. verticillioides, 56,8\% foram isoladas na região de Palmital, assim distribuídas: 11,6\% nas amostras de cobertura morta e 88,4\% em amostras de grãos de milho, e 43,2\% na região de Capão Bonito, 2,0\% na cobertura morta e 98,0\% em amostras de milho.

Entre as cepas de $F$. verticillioides isoladas nas amostras de grãos de milho da $1^{\text {a }}$ coleta (safra verão 2010/2011) na região de Palmital, 55,5\% estavam presentes nas amostras coletadas no $\mathrm{T} 1$ e os outros $44,5 \%$ estavam presentes nas amostras coletadas no T2. Em Capão Bonito, também na $1^{\text {a }}$ coleta, $48,1 \%$ das cepas de $F$. verticillioides isoladas nas 
amostras de grãos de milho estavam presentes nas amostras coletadas no T1 e 51,9\% estavam presentes nas amostras do T2.

Em relação às cepas de $F$. verticillioides isoladas nas amostras de milho da região de Palmital, referentes à $2^{\mathrm{a}}$ coleta (safra verão 2011/2012), nos tratamentos 1,3 e 4, 25,5\% foram isoladas em cada um, e 23,5\% foram isoladas no T2. Já em Capão Bonito, na última coleta, $35,7 \%$ das cepas de $F$. verticillioides foram isoladas nas amostras de milho do T1, 23,8\% estavam presentes nas amostras do T2, 21,4\% no T3 e 19,1\% no T4. Porém, conforme a análise estatística, a média do percentual de grãos de milho com $F$. verticillioides não variou em função da região e do tratamento.

\subsection{Avaliação da metodologia analítica para determinação das fumonisinas $B_{1}$ e $B_{2}$}

As curvas de calibração, utilizadas para a quantificação das fumonisinas $\mathrm{B}_{1}$ e $\mathrm{B}_{2}$, tanto nas análises das amostras de milho quanto para o potencial toxigênico das cepas de $F$. verticillioides, apresentaram-se lineares nas faixas de concentrações. O coeficiente de correlação para as curvas de calibração 1 foi de 0,999 tanto para $\mathrm{FB}_{1}$ quanto para $\mathrm{FB}_{2}$; já para as curvas de calibração 2, o coeficiente de correlação foi de 0,991 para $\mathrm{FB}_{1}$ e 0,995 para $\mathrm{FB}_{2}$ (Figuras A.1, A.2, A.3 e A.4).

Análise de fumonisinas, utilizando colunas de imunoafinidade, revelou limite de quantificação para $\mathrm{FB}_{1}$ e $\mathrm{FB}_{2}$ de 15,0 $\mu \mathrm{g} / \mathrm{kg}$ (ppb). Os limites de detecção foram de 9,7 $\mu \mathrm{g} / \mathrm{kg}$ para ambas fumonisinas, sendo determinado como a concentração onde a área do pico se encontrava três vezes acima da linha de base padrão. Já o emprego de metodologia utilizando colunas SAX, revelou limite de quantificação para ambas fumonisinas de 50,0 $\mu \mathrm{g} / \mathrm{kg}$.

A recuperação do método foi testada em triplicata, a partir de amostras livre de fumonisinas (nas condições do no experimento) e artificialmente contaminadas com $\mathrm{FB}_{1} \mathrm{e}$ $\mathrm{FB}_{2}$ em seis diferentes níveis de contaminação (entre 15,0 e 300,0 $\mu \mathrm{g} / \mathrm{kg}$ ). Os testes de recuperação apresentaram resultados médios de $94,1 \%$ para $\mathrm{FB}_{1}$ e $95,1 \%$ para $\mathrm{FB}_{2}$.

As quantificações das toxinas, quando presentes, foram realizadas através de curva de calibração. Os tempos de retenção para $\mathrm{FB}_{1}$ e $\mathrm{FB}_{2}$ foram de 7 e 18 minutos, respectivamente. 


\subsection{Determinação de Fumonisinas das Amostras de Milho}

A pesquisa de fumonisinas foi realizada em 144 amostras de grãos de milho (48 amostras referentes à $1^{\text {a }}$ coleta de grãos de milho nas regiões de Palmital e Capão Bonito; 96 amostras referentes à última coleta de milho em Palmital e em Capão Bonito - Tabela B.1).

A análise de fumonisinas das amostras da $1^{\text {a }}$ coleta de milho foi realizada nos T1 e T2. Em Palmital, $\mathrm{FB}_{1}$ foi detectada em 75,0\% das amostras do T1 em níveis que variaram de 18,3 a $123,6 \mu \mathrm{g} / \mathrm{kg}$ (média de $51,0 \mu \mathrm{g} / \mathrm{kg}$ ) e em $58,3 \%$ do T2, em concentrações de 16,5 a 208,0 $\mu \mathrm{g} / \mathrm{kg}$ (média de 63,5 $\mu \mathrm{g} / \mathrm{kg}$ ). Em relação à $\mathrm{FB}_{2}$, a toxina foi detectada em apenas 8,3\% das amostras do T2 (média de 145,8 $\mu \mathrm{g} / \mathrm{kg}$ ) (Tabela 14). Em Capão Bonito, FB F $_{1}$ foi detectada em $58,3 \%$ das amostras do T1, em concentrações que variaram de 18,6 a 151,2 $\mu \mathrm{g} / \mathrm{kg}$ (média de $55,8 \mu \mathrm{g} / \mathrm{kg}$ ), e em $66,7 \%$ do T2, em concentrações que variaram de 15,1 a $145,5 \mu \mathrm{g} / \mathrm{kg}$ (média de $46,2 \mu \mathrm{g} / \mathrm{kg}$ ). Duas amostras, uma de cada tratamento, apresentaram contaminação por $\mathrm{FB}_{2}$ com concentrações de $131,9 \mu \mathrm{g} / \mathrm{kg}$ no T1 e $150,3 \mu \mathrm{g} / \mathrm{kg}$ no T2 (Tabela 15).

Tabela 14 - Correlação entre a frequência de $F$. verticillioides, a porcentagem de amostras contaminadas por fumonisinas $\left(\mathrm{FB}=\mathrm{FB}_{1}+\mathrm{FB}_{2}\right)$ e a concentração média de fumonisinas nas amostras de grãos de milho coletadas em Palmital.

\begin{tabular}{|c|c|c|c|c|c|c|}
\hline \multirow[b]{3}{*}{ Tratamentos } & \multicolumn{6}{|c|}{ PALMITAL } \\
\hline & \multicolumn{3}{|c|}{ Milho Safra Verão 2010/2011 } & \multicolumn{3}{|c|}{ Milho Safra Verão 2011/2012 } \\
\hline & $\begin{array}{c}F . \\
\text { verticillioides }\end{array}$ & $\begin{array}{c}\text { Amostras } \\
\text { contaminadas } \\
\left(\mathbf{F B} \geq \mathbf{L Q}^{5}\right)\end{array}$ & $\begin{array}{c}\text { FB } \\
\text { Média } \\
(\mu \mathrm{g} / \mathrm{Kg})\end{array}$ & $\begin{array}{c}F . \\
\text { verticillioides }\end{array}$ & $\begin{array}{c}\text { Amostras } \\
\text { contaminadas } \\
(\mathrm{FB} \geq \mathbf{L Q})\end{array}$ & $\begin{array}{c}\text { FB } \\
\text { Média } \\
(\mu \mathrm{g} / \mathrm{Kg})\end{array}$ \\
\hline $\mathbf{T 1} \mathbf{1}^{1}$ & $34,4 \%$ & $75,0 \%$ & 51,0 & $69,2 \%$ & $100 \%$ & 700,2 \\
\hline $\mathbf{T} 2^{2}$ & $42,9 \%$ & $58,3 \%$ & 84,3 & $81,8 \%$ & $100 \%$ & 286,8 \\
\hline $\mathbf{T 3}^{3}$ & $\emptyset^{6}$ & $\varnothing$ & $\varnothing$ & $73,7 \%$ & $100 \%$ & 904,7 \\
\hline $\mathbf{T} 4^{4}$ & $\varnothing$ & $\varnothing$ & $\varnothing$ & $56,4 \%$ & $100 \%$ & 892,3 \\
\hline
\end{tabular}

A análise micotoxicológica das amostras da $2^{\mathrm{a}}$ coleta de milho foi realizada em todos tratamentos. Em Palmital, $\mathrm{FB}_{1}$ foi detectada em $100 \%$ das amostras de todos os tratamentos, em concentrações que variaram de 32,3 a 3.803,4 $\mu \mathrm{g} / \mathrm{kg}$ (média de 495,5 $\mu \mathrm{g} / \mathrm{kg}$ ) no T1; 39,6 a $1.387,8 \mu \mathrm{g} / \mathrm{kg}$ (média de 215,0 $\mu \mathrm{g} / \mathrm{kg}$ ) no T2; 51,2 a 4.638,4 $\mu \mathrm{g} / \mathrm{kg}$ (média de 604,7 $\mu \mathrm{g} / \mathrm{kg}$ ) no 
T3; e 54,5 a $2.789,7 \mu \mathrm{g} / \mathrm{kg}$ (média de $631,8 \mu \mathrm{g} / \mathrm{kg}$ ) no T4. A presença de $\mathrm{FB}_{2}$ foi constatada em 25\% das amostras do T1, em concentrações que variaram de 58,2 a 1.963,2 $\mu \mathrm{g} / \mathrm{kg}$ (média de $818,8 \mu \mathrm{g} / \mathrm{kg}$ ). No T2, 8,3\% das amostras estavam contaminadas por $\mathrm{FB}_{2}$ (média de 692,5 $\mu \mathrm{g} / \mathrm{kg}$ ). No T3, 33,3\% das amostras apresentaram contaminação por $\mathrm{FB}_{2}$ em concentrações que variaram de 28,4 a 2.772,5 $\mu \mathrm{g} / \mathrm{kg}$ (média de $900,0 \mu \mathrm{g} / \mathrm{kg}$ ) e, no T4, $50 \%$ das amostras estavam contaminadas em concentrações que variaram de 28,3 a 1.778,0 $\mu \mathrm{g} / \mathrm{kg}$ (média de $563,1 \mu \mathrm{g} / \mathrm{kg}$ ) (Tabela 14). Em Capão Bonito, $\mathrm{FB}_{1}$ foi encontrada em $100 \%$ das amostras dos T1, T2 e T4, em concentrações que variaram de 21,0 a 245,5 $\mu \mathrm{g} / \mathrm{kg}$ (média de 82,5 $\mu \mathrm{g} / \mathrm{kg}$ ), 15,9 a $241,3 \mu \mathrm{g} / \mathrm{kg}$ (média de 106,6 $\mu \mathrm{g} / \mathrm{kg}$ ) e 25,0 a 214,7 $\mu \mathrm{g} / \mathrm{kg}$ (média de 73,1 $\mu \mathrm{g} / \mathrm{kg}$ ), respectivamente. No T3, 91,7\% das amostras estavam contaminadas por $\mathrm{FB}_{1} \mathrm{em}$ concentrações que variaram de 15,3 a 119,6 $\mu \mathrm{g} / \mathrm{kg}$ (média de 50,1 $\mu \mathrm{g} / \mathrm{kg}$ ). Constatamos a presença de $\mathrm{FB}_{2}$ em 16,7\% das amostras do $\mathrm{T} 1$ e do T4, em concentrações que variaram de 81,5 a $249,5 \mu \mathrm{g} / \mathrm{kg}$ (média de 165,5 $\mu \mathrm{g} / \mathrm{kg}$ ) e 71,4 a 165,4 $\mu \mathrm{g} / \mathrm{kg}$ (média de 118,4 $\mu \mathrm{g} / \mathrm{kg}$ ), respectivamente. No T2, 33,3\% das amostras estavam contaminadas por $\mathrm{FB}_{2} \mathrm{em}$ concentrações que variaram de 17,9 a 199,6 $\mu \mathrm{g} / \mathrm{kg}$ (média de 99,0 $\mu \mathrm{g} / \mathrm{kg}$ ). No T3, $25 \%$ das amostras apresentaram contaminação por $\mathrm{FB}_{2}$ em concentrações que variaram de 25,6 a 36,3 $\mu \mathrm{g} / \mathrm{kg}$ (média de 32,2 $\mu \mathrm{g} / \mathrm{kg}$ ) (Tabela 15).

Tabela 15 - Correlação entre a frequência de $F$. verticillioides, a porcentagem de amostras contaminadas por fumonisinas $\left(\mathrm{FB}=\mathrm{FB}_{1}+\mathrm{FB}_{2}\right)$ e a concentração média de fumonisinas nas amostras de grãos de milho coletadas em Capão Bonito.

\begin{tabular}{|c|c|c|c|c|c|c|}
\hline \multirow[b]{3}{*}{ Tratamentos } & \multicolumn{6}{|c|}{ CAPÃO BONITO } \\
\hline & \multicolumn{3}{|c|}{ Milho Safra Verão 2010/2011 } & \multicolumn{3}{|c|}{ Milho Safra Verão 2011/2012 } \\
\hline & $\begin{array}{c}F . \\
\text { verticillioides }\end{array}$ & $\begin{array}{c}\text { Amostras } \\
\text { contaminadas } \\
\left(\mathbf{F B} \geq \mathbf{L} \mathbf{Q}^{5}\right)\end{array}$ & $\begin{array}{c}\text { FB } \\
\text { Média } \\
(\mu \mathrm{g} / \mathrm{Kg})\end{array}$ & $\begin{array}{c}F . \\
\text { verticillioides }\end{array}$ & $\begin{array}{c}\text { Amostras } \\
\text { contaminadas } \\
(\mathbf{F B} \geq \mathbf{L Q})\end{array}$ & $\begin{array}{c}\text { FB } \\
\text { Média } \\
(\mu \mathrm{g} / \mathrm{Kg})\end{array}$ \\
\hline $\mathbf{T} \mathbf{1}^{1}$ & $31,1 \%$ & $58,3 \%$ & 74,6 & $81,8 \%$ & $100 \%$ & 110,1 \\
\hline $\mathbf{T} 2^{2}$ & $30,1 \%$ & $66,7 \%$ & 64,9 & $71,7 \%$ & $100 \%$ & 139,6 \\
\hline $\mathbf{T 3}^{3}$ & $\emptyset^{6}$ & $\varnothing$ & $\varnothing$ & $58,8 \%$ & $91,7 \%$ & 58,9 \\
\hline $\mathbf{T} 4^{4}$ & $\varnothing$ & $\varnothing$ & $\varnothing$ & $64,4 \%$ & $100 \%$ & 92,8 \\
\hline
\end{tabular}

T1: milho/trigo/milho. ${ }^{2}$ T2: milho/milho safrinha/milho. ${ }^{3}$ T3: soja/trigo/milho. ${ }^{4}$ T4: soja/milho safrinha/milho. ${ }^{5}$ LQ: Limite de Quantificação $(\geq 15,0 \mu \mathrm{g} / \mathrm{Kg}) .{ }^{6} \varnothing$ : ausência de milho para a coleta. 


\subsection{Avaliação do Potencial Toxigênico das Cepas de $F$. verticillioides Isoladas Durante o Estudo}

Foram identificadas como $F$. verticillioides (através de metodologia clássica e molecular) 227 cepas, sendo 56,8\% isoladas nas amostras referentes a todas as coletas da região de Palmital (11,6\% nas amostras de cobertura morta e 88,4\% em amostras de grãos de milho) e 43,2\% na região de Capão Bonito (2,0\% na cobertura morta e 98,0\% em amostras de milho). Nestas cepas, foi realizada a verificação da potencialidade toxigênica quanto à produção de fumonisinas $\mathrm{B}_{1}$ e $\mathrm{B}_{2}$ (Tabela B.2).

Da totalidade das 227 cepas de $F$. verticillioides, verificou-se que 51,1\% (116/227) foram capazes de produzir (com valores acima do limite de quantificação) apenas $\mathrm{FB}_{1}$, e $33,5 \%(76 / 236)$ produziram ambas as toxinas $\left(\mathrm{FB}_{1}\right.$ e $\left.\mathrm{FB}_{2}\right)$. Vale ressaltar que, mesmo as cepas que não produziram níveis detectáveis de $\mathrm{FB}_{1}$ ou aquelas que produziram níveis de toxina abaixo do limite de quantificação ( $\mathrm{LQ}=50,0 \mu \mathrm{g} / \mathrm{Kg}$ ), se tratavam de $F$. verticillioides, pois foram anteriormente identificadas através de metodologia clássica e confirmadas através do sequenciamento parcial do gene do fator de elongação $1 \alpha$. Os níveis de $\mathrm{FB}_{1}$ variaram de 59,8 a $57.174,1 \mu \mathrm{g} / \mathrm{Kg}$, e os níveis de $\mathrm{FB}_{2}$ variaram de 53,0 a 40.021,9 $\mu \mathrm{g} / \mathrm{Kg}$. Os valores médios de $\mathrm{FB}_{1}$ e $\mathrm{FB}_{2}$ foram 1.396,6 e 592,6 $\mu \mathrm{g} / \mathrm{Kg}$, respectivamente (Tabela B.2).

Destas cepas, 56,8\% (129/227) foram isoladas nas amostras referentes à região de Palmital [6,6\% (15/227) nas amostras de cobertura morta e 50,2\% (114/227) em amostras de grãos de milho] e 43,2\% (98/227) na região de Capão Bonito [0,9\% (2/227) em amostras de cobertura morta e 42,3\% (96/227) em amostras de milho] (Tabela B.2).

Em relação à região de Palmital, nas 2 coletas de amostras de cobertura morta realizadas, um total de $15\left(11,6 \%\right.$ - 15/129) cepas de F. verticillioides foram isoladas. Na $1^{\text {a }}$ coleta (realizada antes do plantio do milho safra verão 2010/2011), 7 (46,7\% - 7/15) cepas foram isoladas e, dentre estas, $6\left(85,7 \%\right.$ - 6/7) produziram apenas $\mathrm{FB}_{1}$, em concentrações que variaram de 80,9 a 321,2 $\mu \mathrm{g} / \mathrm{Kg}$, e 1 (14,3\% - 1/7) produziu $\mathrm{FB}_{1}$ e $\mathrm{FB}_{2}$, na concentração de 511,2 e $369,1 \mu \mathrm{g} / \mathrm{Kg}$, respectivamente. $\mathrm{Na} 2^{\mathrm{a}}$ coleta (realizada antes do plantio do milho safra verão 2011/2012), $8(53,3 \%$ - 8/15) cepas foram isoladas e, dentre estas, $6(75,0 \%$ - 6/8) produziram apenas $\mathrm{FB}_{1}$, em concentrações que variaram de 315,4 a 713,9 $\mu \mathrm{g} / \mathrm{Kg}$, 1 (12,5\% 1/8) produziu $\mathrm{FB}_{1}$ e $\mathrm{FB}_{2}$, na concentração de 815,3 e $294,4 \mu \mathrm{g} / \mathrm{Kg}$, respectivamente, e 1 $(12,5 \%$ - 1/8) produziu toxinas em níveis abaixo do limite de quantificação (Tabela B.2).

Ainda em Palmital, mas agora analisando as duas coletas de grãos de milho realizadas na região, um total de $114\left(88,4 \%\right.$ - 114/129) cepas de F. verticillioides foram isoladas. Na $1^{\text {a }}$ 
coleta (safra verão 2010/2011), foram isoladas 63 (55,3\% - 63/114) cepas de F. verticillioides, sendo que 27 (42,9\% - 27/63) cepas produziram $\mathrm{FB}_{1}$ em concentrações que variaram de 59,8 a 4.646,9 $\mu \mathrm{g} / \mathrm{Kg}, 22$ (34,9\% - 22/63) produziram $\mathrm{FB}_{1}$ e $\mathrm{FB}_{2}$ em concentrações que variaram de 143,3 a 5.020,7 $\mu \mathrm{g} / \mathrm{Kg}$ para $\mathrm{FB}_{1}$ e de 62,4 a $1.497,9 \mu \mathrm{g} / \mathrm{Kg}$ para $\mathrm{FB}_{2}, 9(14,3 \%$ - 9/63) produziram toxinas em níveis abaixo do limite de quantificação e $5(7,9 \%$ - 5/63) não produziram níveis detectáveis de fumonisinas. Já na segunda e última coleta de grãos de milho de Palmital (safra verão 2011/2012), 51 (44,7\% - 51/114) cepas de F. verticillioides foram isoladas e, dentre estas, 25 (49,0\% - 25/51) produziram $\mathrm{FB}_{1}$ em concentrações que variaram de 194,4 a 1.631,8 $\mu \mathrm{g} / \mathrm{Kg}, 20$ (39,2\% - 20/51) produziram $\mathrm{FB}_{1}$ e $\mathrm{FB}_{2}$ em concentrações que variaram de 330,9 a $57.174,1 \mu \mathrm{g} / \mathrm{Kg}$ para $\mathrm{FB}_{1}$ e de 53,5 a $40.021,9 \mu \mathrm{g} / \mathrm{Kg}$ para $\mathrm{FB}_{2}$ e $6(11,8 \%$ - 6/51) produziram fumonisinas em níveis abaixo do limite de quantificação (Tabela B.2).

$\mathrm{Na}$ região de Capão Bonito, analisando as 2 coletas de cobertura morta, verificou-se um isolamento total de $2\left(2,1 \%\right.$ - 2/98) cepas de F. verticillioides, ambas na $2^{\text {a }}$ coleta (antes do plantio do milho safra verão 2011/2012). Estas cepas produziram apenas $\mathrm{FB}_{1}$, nas concentrações que de 68,6 e 219,3 $\mu \mathrm{g} / \mathrm{Kg}$ (Tabela B.2).

Analisando as duas coletas de grãos de milho realizadas em Capão Bonito, observouse um total de $96\left(97,9 \%\right.$ - 96/98) cepas de F. verticillioides. Na $1^{\text {a }}$ coleta (safra verão 2010/2011), foram isoladas 54 (56,2\% - 54/96) cepas, sendo que 23 (42,6\% - 23/54) produziram $\mathrm{FB}_{1}$ em concentrações que variaram de 77,8 a 4.868,9 $\mu \mathrm{g} / \mathrm{Kg}, 18$ (33,3\% - 18/54) produziram $\mathrm{FB}_{1}$ e $\mathrm{FB}_{2}$ em concentrações que variaram de 165,8 a 23.442,9 $\mu \mathrm{g} / \mathrm{Kg}$ para $\mathrm{FB}_{1}$ e de 78,1 a $21.667,9 \mu \mathrm{g} / \mathrm{Kg}$ para $\mathrm{FB}_{2}, 9(16,7 \%$ - 9/54) produziram fumonisinas em níveis abaixo do limite de quantificação e 4 (7,4\% - 4/54) não produziram níveis detectáveis de fumonisinas. Na segunda e última coleta de grãos de milho de Capão Bonito (safra verão 2011/2012), 42 (43,8\% - 42/96) cepas de F. verticillioides foram isoladas e, dentre estas, 27 $\left(64,3 \%\right.$ - 27/42) produziram apenas $\mathrm{FB}_{1}$ em concentrações que variaram de 251,3 a 4.189,9 $\mu \mathrm{g} / \mathrm{Kg}, 14$ (33,3\% - 14/42) produziram $\mathrm{FB}_{1}$ e $\mathrm{FB}_{2}$ em concentrações que variaram de 260,6 a $4.729,9 \mu \mathrm{g} / \mathrm{Kg}$ para $\mathrm{FB}_{1}$ e de 53,0 a $1.626,1 \mu \mathrm{g} / \mathrm{Kg}$ para $\mathrm{FB}_{2}$ e $1(2,4 \%$ - 1/42) cepa produziu fumonisinas em níveis abaixo do limite de quantificação (Tabela B.2).

\subsection{Análise dos Fatores Climatológicos das Regiões de Estudo}

Dados referentes às temperaturas mínima e máxima $\left({ }^{\circ} \mathrm{C}\right)$ e à quantidade de chuvas por metro quadrado (índice pluviométrico - $\mathrm{mm}$ ) das duas regiões durante todo o período do 
experimento (outubro/2010 a março/2012) foram coletados diariamente em Estações Meteorológicas automatizadas próximas aos locais dos experimentos $(500 \mathrm{~m})$, sob a responsabilidade do Instituto Agronômico de Campinas (IAC), os quais foram atentamente analisados e os resultados expressos (Tabela 16; Figuras 21 e 22).

Tabela 16 - Precipitação pluvial mensal e valores médios de temperaturas mínima e máxima em Palmital e Capão Bonito (Fonte: IAC).

\begin{tabular}{|c|c|c|c|c|c|c|}
\hline \multirow[b]{2}{*}{ Mês/Ano } & \multicolumn{3}{|c|}{ Palmital } & \multicolumn{3}{|c|}{ Capão Bonito } \\
\hline & Chuva $(\mathrm{mm})^{1}$ & $\mathrm{~T}^{\circ} \mathrm{C}$ máx. ${ }^{2}$ & $\mathrm{~T}^{\circ} \mathrm{C}$ mín. $^{3}$ & Chuva (mm) & $\mathbf{T}^{\circ} \mathbf{C}$ máx. & $\mathbf{T}{ }^{\circ} \mathbf{C}$ mín. \\
\hline out $/ 10$ & 202,1 & 28,9 & 14,9 & 104,4 & 22,9 & 12,7 \\
\hline nov/10 & 61,4 & 30,3 & 16,5 & 73,5 & 25,5 & 14,8 \\
\hline $\mathrm{dez} / 10$ & 153,1 & 29,7 & 19,2 & 278,9 & 25,2 & 15,8 \\
\hline $\mathrm{jan} / 11$ & 230,3 & 31,2 & 19,7 & 178,5 & 26,3 & 16,9 \\
\hline $\mathrm{fev} / 11$ & 371,4 & 31,3 & 19,7 & 183,9 & 27,4 & 17,3 \\
\hline $\mathrm{mar} / 11$ & 77,3 & 28,7 & 18,9 & 46,1 & 23,9 & 16,6 \\
\hline abr/11 & 76,5 & 29,2 & 16,1 & 92,0 & 24,1 & 14,1 \\
\hline mai/11 & 12,8 & 25,3 & 9,9 & 8,6 & 20,8 & 10,1 \\
\hline jun/11 & 50,3 & 23,5 & 6,6 & 72,2 & 19,2 & 6,6 \\
\hline $\mathrm{jul} / 11$ & 32,3 & 26,8 & 10,5 & 44,4 & 20,8 & 9,1 \\
\hline ago/11 & 50,5 & 28,6 & 11 & 87,5 & 20,4 & 9,8 \\
\hline set/11 & 4,5 & 30,8 & 11,9 & 4,5 & 21,9 & 10,2 \\
\hline out/11 & 253,2 & 30,1 & 16,4 & 221,5 & 23,5 & 12,3 \\
\hline nov/11 & 75,9 & 29,9 & 15,8 & 83,2 & 23,8 & 11,7 \\
\hline $\operatorname{dez} / 11$ & 65,4 & 32,6 & 17,2 & 131,1 & 26,3 & 12,7 \\
\hline $\mathrm{jan} / 12$ & 171,6 & 30,2 & 17,9 & 338,3 & 24,7 & 13,2 \\
\hline $\mathrm{fev} / 12$ & 54,0 & 33,6 & 18,5 & 274,4 & 28,5 & 16,2 \\
\hline mar/12 & 88,6 & 31,4 & 17,3 & 87,8 & 25,5 & 15,2 \\
\hline
\end{tabular}

${ }^{1}$ Quantidade de chuvas por metro quadrado (índice pluviométrico): soma mensal; ${ }^{2}$ Temperatura máxima $\left({ }^{\circ} \mathrm{C}\right.$ ): média mensal; ${ }^{3}$ Temperatura mínima $\left({ }^{\circ} \mathrm{C}\right)$ : média mensal. 
Figura 21 - Dados climatológicos [índice pluviométrico $(\mathrm{mm})$, temperaturas máxima média $\left({ }^{\circ} \mathrm{C}\right)$ e mínima média $\left({ }^{\circ} \mathrm{C}\right)$ ] referentes ao período de outubro/2010 a março/2012 registrados na região de Palmital - SP.

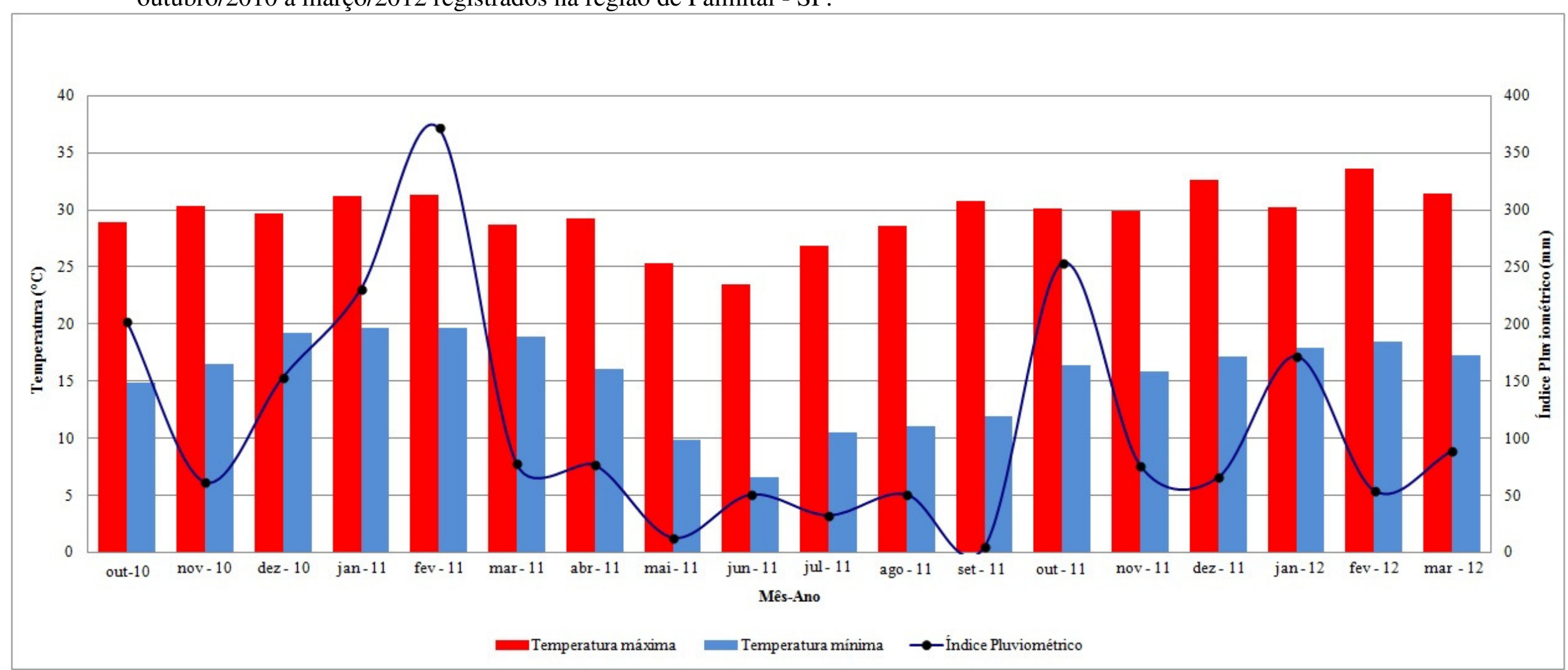


Figura 22 - Dados climatológicos [índice pluviométrico $(\mathrm{mm})$, temperaturas máxima média $\left({ }^{\circ} \mathrm{C}\right)$ e mínima média $\left({ }^{\circ} \mathrm{C}\right)$ ] referentes ao período de outubro/2010 a março/2012 registrados na região de Capão Bonito - SP.

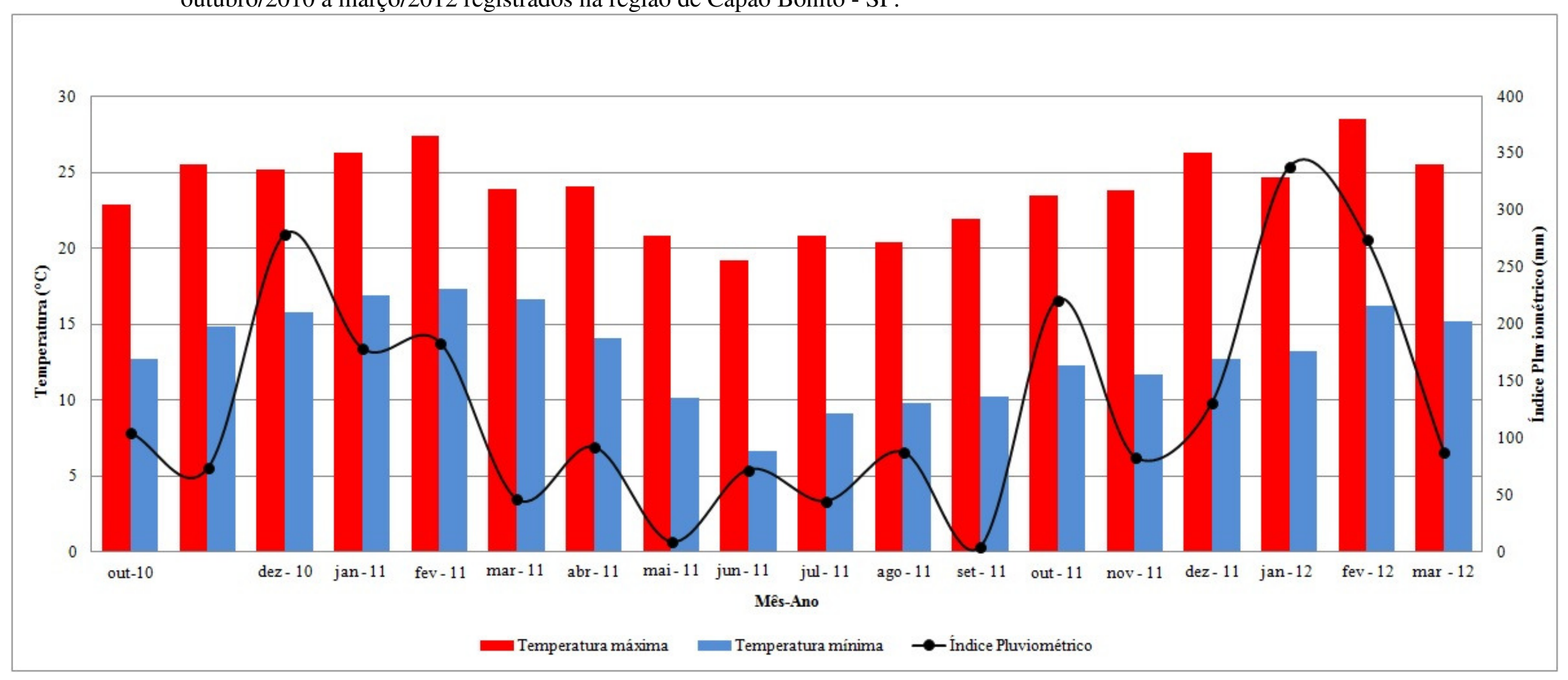


Vale ressaltar que as coletas na região de Palmital foram realizadas nos seguintes períodos, em ordem cronológica: $1^{\mathrm{a}}$ coleta de cobertura morta - outubro/2010; $1^{\mathrm{a}}$ coleta de milho (safra verão 2010/2011) - fevereiro/2011; $2^{\text {a }}$ coleta de cobertura morta - outubro/2011; $2^{\mathrm{a}}$ coleta de milho (safra verão 2011/2012) - fevereiro/2012.

Já em Capão Bonito, as coletas foram realizadas nos seguintes períodos: $1^{\mathrm{a}}$ coleta de cobertura morta - outubro/2010; $1^{\text {a }}$ coleta de milho (safra verão 2010/2011) - março/2011; $2^{\text {a }}$

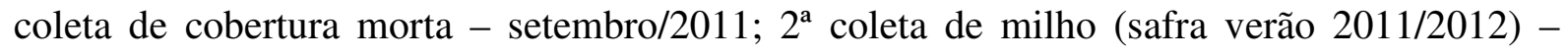
março/2012.

\subsection{Análise Estatística}

\subsubsection{Análise exploratória}

As tabelas 17 a 22 apresentam estatísticas descritivas para as variáveis coletadas no estudo, segmentadas por região e tratamento.

Observamos que, tanto nas amostras de Palmital quanto nas de Capão Bonito coletadas na safra verão 2011/2012, o percentual observado de grãos de milho contaminados com F. verticillioides, em média, foi alto (Tabela 17).

Tabela 17 - Estatísticas descritivas para a variável "isolamento de $F$. verticillioides no milho", em porcentagem de grãos contaminados (33 grãos analisados por amostra).

\begin{tabular}{ccccccc}
\hline Região & Tratamento & $\begin{array}{c}\text { Média } \\
\text { \% }\end{array}$ & $\begin{array}{c}\text { Desvio } \\
\text { padrão }\end{array}$ & Mínimo & Máximo & $\begin{array}{c}\text { \% de } \\
\text { Zeros* }\end{array}$ \\
\hline \multirow{2}{*}{ Palmital } & 1 & 69,2 & 22,1 & 36,4 & 97,0 & 0,0 \\
& 2 & 81,8 & 21,3 & 39,4 & 100,0 & 0,0 \\
& 3 & 73,7 & 37,2 & 0,0 & 100,0 & 16,7 \\
& 4 & 56,4 & 43,3 & 0,0 & 100,0 & 25,0 \\
\hline Capão & 1 & 81,8 & 27,9 & 0,0 & 100,0 & 8,3 \\
Bonito & 2 & 71,7 & 35,5 & 0,0 & 100,0 & 16,7 \\
& 3 & 58,8 & 43,6 & 0,0 & 97,0 & 33,3 \\
& 4 & 64,4 & 39,7 & 0,0 & 93,9 & 25,0 \\
\hline
\end{tabular}

* \% de zeros: grãos isentos de contaminação por $F$. verticillioides.

Para todos os tratamentos, em ambas as regiões analisadas, a média de isolamento de F. verticillioides foi superior a $56 \%$ e inferior a $82 \%$, e o percentual de amostras sem nenhum grão contaminado com esta espécie fúngica foi inferior a $34 \%$. Os resultados sugerem que a 
média do percentual de grãos de milhos com $F$. verticillioides não pareceu variar em função da região e do tratamento (Tabela 17).

Em relação à cobertura morta ( $2^{\mathrm{a}}$ coleta/última), observamos que $F$. verticillioides foi isolado em todos os tratamentos na região de Palmital. Nos tratamentos 1, 2 e 3 de Capão Bonito nenhuma amostra observada continha fungos dessa espécie (Tabela 18).

Tabela 18 - Estatísticas descritivas para a variável "isolamento de $F$. verticillioides na cobertura morta", x $10^{4}$ Unidades Formadoras de Colônias por grama de substrato (UFC/g).

\begin{tabular}{ccccccc}
\hline Região & Tratamento & Média & $\begin{array}{c}\text { Desvio } \\
\text { padrão }\end{array}$ & Mínimo & Máximo & $\begin{array}{c}\% \text { de } \\
\text { Zeros* }\end{array}$ \\
\hline Palmital & 1 & 42,5 & 48,1 & 0,0 & 110,0 & 50 \\
& 2 & 7,5 & 13,6 & 0,0 & 30,0 & 75 \\
& 3 & 1,3 & 2,3 & 0,0 & 5,0 & 75 \\
& 4 & 20,0 & 20,9 & 0,0 & 40,0 & 50 \\
\hline Capão & 1 & 0,0 & 0,0 & 0,0 & 0,0 & 100 \\
Bonito & 2 & 0,0 & 0,0 & 0,0 & 0,0 & 100 \\
& 3 & 0,0 & 0,0 & 0,0 & 0,0 & 100 \\
& 4 & 15,0 & 21,5 & 0,0 & 50,0 & 50 \\
\hline
\end{tabular}

* \% de zeros: grãos isentos de contaminação por $F$. verticillioides.

Verificou-se que a presença de $\mathrm{FB}_{1}$ pareceu, em média, maior em Palmital do que em Capão Bonito. Notamos ainda que a detecção de $\mathrm{FB}_{1}$ nos tratamentos diferiu de acordo com a região. O tratamento 2, por exemplo, foi aquele que apresentou a menor média de presença de $\mathrm{FB}_{1}$ em Palmital e maior média em Capão Bonito. Nota-se ainda que das 96 amostras analisadas de ambas as regiões, apenas uma proveniente de Capão Bonito não apresentou $\mathrm{FB}_{1}$ (Tabela 19).

Tabela 19 - Estatísticas descritivas para a variável "detecção de $\mathrm{FB}_{1}$ ”, em $\mu \mathrm{g} / \mathrm{kg}$.

\begin{tabular}{ccccccc}
\hline Região & Tratamento & Média & $\begin{array}{c}\text { Desvio } \\
\text { padrão }\end{array}$ & Mínimo & Máximo & $\begin{array}{c}\% \text { de } \\
\text { Zeros* }\end{array}$ \\
\hline \multirow{2}{*}{ Palmital } & 1 & 495,5 & 1068,6 & 32,3 & 3803,4 & 0,0 \\
& 2 & 215,0 & 377,5 & 39,6 & 1387,8 & 0,0 \\
& 3 & 604,7 & 1327,7 & 51,2 & 4638,4 & 0,0 \\
& 4 & 631,8 & 855,0 & 54,5 & 2789,7 & 0,0 \\
\hline Capão & 1 & 82,5 & 70,6 & 21,1 & 245,5 & 0,0 \\
Bonito & 2 & 106,6 & 78,2 & 15,9 & 241,3 & 0,0 \\
& 3 & 50,1 & 33,8 & 0,0 & 119,6 & 8,3 \\
& 4 & 73,1 & 55,4 & 25,1 & 214,7 & 0,0 \\
\hline
\end{tabular}

* \% de zeros: grãos isentos de contaminação por $F$. verticillioides. 
Para todos os tratamentos e em ambas as regiões, em metade ou mais das amostras, não foi observada a presença de $\mathrm{FB}_{2}$ e não pareceu haver diferença entre os tratamentos e regiões em relação à proporção de amostras contaminadas por esta fumonisina (Tabela 20). Porém, nas amostras em que detectou-se $\mathrm{FB}_{2}$, ela foi, em média, maior em Palmital do que em Capão Bonito.

Tabela 20 - Estatísticas descritivas para a variável “detecção de $\mathrm{FB}_{2}$ ”, em $\mu \mathrm{g} / \mathrm{kg}$.

\begin{tabular}{ccccccc}
\hline Região & Tratamento & Média & $\begin{array}{c}\text { Desvio } \\
\text { padrão }\end{array}$ & Mínimo & Máximo & $\begin{array}{c}\% \text { de } \\
\text { Zeros* }\end{array}$ \\
Palmital & 1 & 204,7 & 567,6 & 0,0 & 1963,2 & 75,0 \\
& 2 & 71,9 & 201,5 & 0,0 & 692,5 & 83,3 \\
& 3 & 300,0 & 801,8 & 0,0 & 2772,5 & 66,7 \\
& 4 & 281,5 & 515,8 & 0,0 & 1778,0 & 50,0 \\
\hline Capão & 1 & 27,6 & 73,7 & 0,0 & 249,5 & 83,3 \\
Bonito & 2 & 33,0 & 62,6 & 0,0 & 199,6 & 66,7 \\
& 3 & 8,0 & 14,8 & 0,0 & 36,3 & 75,0 \\
& 4 & 19,7 & 50,3 & 0,0 & 165,4 & 83,3 \\
\hline
\end{tabular}

* \% de zeros: grãos isentos de contaminação por F. verticillioides.

Em relação à Aa nas amostras de grãos de milho, notamos que, em ambas as regiões, as médias foram superiores a $0,92 \mathrm{em}$ todos os tratamentos e a variabilidade foi baixa. Porém, em Capão Bonito, as médias de Aa foram ligeiramente maiores e os desvios padrões foram ainda menores. Não foi constatada diferença entre as médias da Aa entre os tratamentos (Tabela 21).

Tabela 21 - Estatísticas descritivas para a variável "atividade de água no milho".

\begin{tabular}{lcrrrr}
\hline Região & Tratamento & Média & $\begin{array}{c}\text { Desvio } \\
\text { padrão }\end{array}$ & Mínimo & Máximo \\
\hline Palmital & 1 & 0,94 & 0,02 & 0,89 & 0,97 \\
& 2 & 0,93 & 0,05 & 0,83 & 0,97 \\
& 3 & 0,93 & 0,04 & 0,85 & 0,98 \\
& 4 & 0,93 & 0,04 & 0,86 & 0,98 \\
\hline Capão & 1 & 0,97 & 0,01 & 0,96 & 0,98 \\
Bonito & 2 & 0,97 & 0,01 & 0,95 & 0,98 \\
& 3 & 0,97 & 0,01 & 0,96 & 0,98 \\
& 4 & 0,96 & 0,01 & 0,94 & 0,98 \\
\hline
\end{tabular}


A atividade de água na cobertura morta apresentou médias entre 0,46 e 0,50 para todos os tratamentos em ambas as regiões e baixa variabilidade (Tabela 22), não havendo diferença entre as regiões e os tratamentos em relação à média da Aa na cobertura morta.

Tabela 22 - Estatísticas descritivas para a variável "atividade de água na cobertura morta".

\begin{tabular}{lccccc}
\hline Região & Tratamento & Média & $\begin{array}{c}\text { Desvio } \\
\text { padrão }\end{array}$ & Mínimo & Máximo \\
\hline Palmital & 1 & 0,46 & 0,02 & 0,44 & 0,48 \\
& 2 & 0,47 & 0,01 & 0,46 & 0,49 \\
& 3 & 0,46 & 0,02 & 0,44 & 0,48 \\
& 4 & 0,47 & 0,02 & 0,45 & 0,49 \\
\hline Capão & 1 & 0,50 & 0,02 & 0,47 & 0,52 \\
Bonito & 2 & 0,48 & 0,00 & 0,47 & 0,48 \\
& 3 & 0,47 & 0,02 & 0,45 & 0,49 \\
& 4 & 0,49 & 0,01 & 0,48 & 0,50 \\
\hline
\end{tabular}

\subsubsection{Análise inferencial}

Para analisar o efeito das variáveis no isolamento de $F$. verticillioides e na determinação de $\mathrm{FB}_{1}$ e $\mathrm{FB}_{2}$, foram utilizados modelos da classe GAMLSS (RIGBY; STASINOPOULOS, 2005).

Para a presença de $F$. verticillioides, foi utilizado o modelo beta binomial inflacionado no zero. Para a detecção de $\mathrm{FB}_{1}$, foi utilizado o modelo Weibull e, para a $\mathrm{FB}_{2}$, foi utilizado o modelo gaussiana inversa inflacionado no zero.

Para estudo da presença de $F$. verticillioides, as variáveis preditoras consideradas foram: região, tratamento, interação entre região e tratamento, atividade de água no milho, atividade de água na cobertura morta e o isolamento de $F$. verticillioides na cobertura morta. Como a maioria das amostras de cobertura morta não continha $F$. verticillioides, esta variável foi segmentada em apenas 2 níveis: presença ou ausência da espécie fúngica em estudo. Para a detecção das fumonisinas, foi incluída a variável porcentagem de grãos de milhos infectados por $F$. verticillioides.

O nível de significância utilizado em todos os modelos foi de 5\%. Quando necessário, o método utilizado para a realização de comparações múltiplas foi o de Bonferroni (NETER et al., 1996). 


\subsubsection{Análise do isolamento de F. verticillioides}

Observamos que a proporção de grãos de milho infectados por $F$. verticillioides variou em função da presença ou ausência desta mesma espécie na cobertura morta $(p=0,0008)$. Porém, não houve indícios de que a proporção de grãos de milho infectados por $F$. verticillioides variou em função da região $(\mathrm{p}=0,66)$, do tratamento $(\mathrm{p}=0,57)$, da interação entre região e tratamento $(\mathrm{p}=0,23)$, da atividade de água no milho $(\mathrm{p}=0,19)$ e da atividade de água na cobertura morta $(\mathrm{p}=0,98)$ (Tabelas 23 e 24).

Tabela 23 - Estimativas e valores-p do ajuste do modelo de regressão beta binomial inflacionado no zero para a variável "isolamento de F. verticillioides no milho".

\begin{tabular}{cccc|cc}
\hline Parâmetro & Variável & Estimativa & $\begin{array}{c}\text { Erro } \\
\text { padrão }\end{array}$ & Valor-p & $\begin{array}{c}\text { Exp. da } \\
\text { estimat. }\end{array}$ \\
\hline Média & $\begin{array}{c}\text { Intercepto } \\
\text { Presença de } F . \\
\text { verticillioides na } \\
\text { cobertura morta }\end{array}$ & 1,806 & 0,158 & --- & \\
\hline
\end{tabular}

Tabela 24 - Valores-p das variáveis não incluídas no modelo de regressão beta binomial inflacionado no zero para a variável "isolamento de F. verticillioides no milho".

\begin{tabular}{cc}
\hline Variável & Valor-p \\
Região & 0,66 \\
Tratamento & 0,57 \\
Interação Região e Tratamento & 0,23 \\
Aa do milho & 0,19 \\
Aa da cobertura morta & 0,98 \\
\hline
\end{tabular}

O efeito da presença de $F$. verticillioides na cobertura morta na proporção de grãos de milho que infectados por este fungo foi contrário ao esperado. Observando-se a última coluna da tabela 23, foi possível estimar que a chance de um grão de milho conter $F$. verticillioides é $62 \%$ menor se a cobertura morta apresentar esse fungo.

\subsubsection{Análise dos níveis de $F B_{1}$ nas amostras de grãos de milho}

Notamos que a média dos níveis de $\mathrm{FB}_{1}$ nas amostras de milho variou em função da interação entre região e tratamento $(\mathrm{p}=0,0224)$ e da porcentagem de grãos de milho infectados por $F$. verticillioides $(\mathrm{p}=0,0026)$. Porém, não houve indícios de que esses níveis 
variaram em função da atividade de água do milho $(\mathrm{p}=0,786)$, da atividade de água da cobertura morta $(p=0,736)$ e da presença de $F$. verticillioides na cobertura morta $(p=0,243)$ (Tabelas 25 e 26).

Tabela 25 - Estimativas e valores-p do ajuste do modelo de regressão Weibull para a variável "nível de $\mathrm{FB}_{1}$ no milho".

\begin{tabular}{|c|c|c|c|c|c|c|}
\hline Parâmetro & Variável & Nível & Estimativa & $\begin{array}{c}\text { Erro } \\
\text { padrão }\end{array}$ & Valor-p & $\begin{array}{l}\text { Exp. da } \\
\text { estimat. }\end{array}$ \\
\hline \multirow[t]{9}{*}{ Média } & Intercepto & & 6,544 & 0,432 & --- & \\
\hline & Região & C. P & $-1,507$ & 0,449 & --- & 0,222 \\
\hline & Tratamento & 2 & $-0,612$ & 0,566 & --- & 0,542 \\
\hline & & 3 & 0,277 & 0,565 & --- & 1,320 \\
\hline & & 4 & 0,404 & 0,564 & --- & 1,497 \\
\hline & Interação & $\mathrm{CP} 2$ & 0,848 & 0,631 & & 2,335 \\
\hline & Região e & $\mathrm{CP} 3$ & $-1,150$ & 0,640 & 0,0224 & 0,317 \\
\hline & Tratamento & $\mathrm{CP} 4$ & $-0,692$ & 0,632 & & 0,501 \\
\hline & $\begin{array}{c}\text { Porcentagem } F \text {. } \\
\text { verticillioides }\end{array}$ & & $-0,008$ & 0,003 & 0,0026 & 0,992 \\
\hline \multirow[t]{2}{*}{ Dispersão } & Intercepto & & $-0,322$ & 0,102 & --- & \\
\hline & Região & C. P & 0,702 & 0,151 & $<0,0001$ & 2,018 \\
\hline
\end{tabular}

Tabela 26 - Valores-p das variáveis não incluídas no modelo de regressão Weibull para a variável "nível de $\mathrm{FB}_{1}$ no milho".

\begin{tabular}{cc}
\hline Variável & Valor-p \\
\hline Aa do milho & 0,786 \\
Aa da cobertura morta & 0,736 \\
$\begin{array}{c}\text { Presença de } F \text {. verticillioides na } \\
\text { cobertura morta }\end{array}$ & 0,243 \\
\hline
\end{tabular}

O fato de haver interação entre região e tratamento significa que o efeito do tratamento no nível médio de $\mathrm{FB}_{1}$ variou de acordo com a região considerada e que o efeito da região no nível médio de $\mathrm{FB}_{1}$ variou de acordo com o tratamento. Dessa forma, foi necessário comparar os tratamentos separadamente para cada região e as duas regiões separadamente para cada tratamento.

Pelo fato de haver múltiplas comparações entre os níveis de uma variável, utiliza-se algum critério para garantir que o nível de significância global se mantenha em 5\%. Utilizouse o critério de Bonferroni e, assim, para comparação entre os tratamentos, foi necessário assumir o valor-p inferior a 0,0042 (5\% dividido por 12 comparações) para que pudéssemos considerar que ocorreu diferença entre os tratamentos em relação ao nível médio de $\mathrm{FB}_{1}$. Já 
para a comparação entre regiões, foi necessário assumir o valor-p inferior a 0,0125 (5\% dividido por 4 comparações).

Notamos que, em Capão Bonito $(\mathrm{p}=0,0006)$, houve indícios de que o nível médio de $\mathrm{FB}_{1}$ no milho foi menor quando realizada a rotação entre as culturas de soja, trigo e milho (tratamento 3) do que quando foi plantado apenas milho (tratamento 2) em todos os ciclos (Tabela 27). Porém, não houve indícios de que a média da produção de $\mathrm{FB}_{1}$ no milho foi menor no tratamento 3 do que nos tratamentos 1 e 4 e nem que houveram diferenças entre os tratamentos 1, 2 e 4. Para Palmital, não houve indícios de que o nível médio de $\mathrm{FB}_{1}$ variou entre os tratamentos. Concluímos ainda que o nível médio de $\mathrm{FB}_{1}$ foi maior em Palmital do que Capão Bonito para os tratamentos 1, 3 e 4 e que não houve indícios de diferença entre essas regiões quanto ao nível médio de $\mathrm{FB}_{1}$ no tratamento 2 (Tabela 27).

Vale ressaltar que o nível médio de $\mathrm{FB}_{1}$ nas amostras de milho provenientes de Capão Bonito foi $67 \%$ menor quando realizada rotação entre as culturas de soja, trigo e milho em comparação à monocultura. Observamos ainda, diferentemente do esperado, que a cada aumento de um ponto percentual de grãos de milho infectados por $F$. verticillioides, a contaminação por $\mathrm{FB}_{1}$ diminui $0,8 \%$ (Tabela 25).

Tabela 27 - Comparações múltiplas no modelo de regressão Weibull para a variável "nível de $\mathrm{FB}_{1}$ no milho".

\begin{tabular}{ccc|c}
\hline Comparação & $\begin{array}{c}\text { Níveis da } \\
\text { comparação }\end{array}$ & $\begin{array}{c}\text { Nível da } \\
\text { outra varável }\end{array}$ & Valor-p \\
\hline Tratamento & 1 e 2 & Palmital & 0,2876 \\
& 1 e 3 & Palmital & 0,6249 \\
& 1 e 4 & Palmital & 0,4756 \\
2 e 3 & Palmital & 0,1287 \\
2 e 4 & Palmital & 0,0815 \\
3 e 4 & Palmital & 0,8231 \\
& 1 e 2 & Capão Bonito & 0,4008 \\
1 e 3 & Capão Bonito & 0,0055 \\
& 1 e 4 & Capão Bonito & 0,3132 \\
2 e 3 & Capão Bonito & 0,0006 \\
& 2 e 4 & Capão Bonito & 0,0531 \\
& 3 e 4 & Capão Bonito & 0,0465 \\
\hline Região & Palm e C. B. & 1 & 0,0004 \\
& Palm e C. B. & 2 & 0,1222 \\
& Palm e C. B. & 3 & $<0,0001$ \\
& Palm e C. B. & 4 & $<0,0001$ \\
\hline
\end{tabular}




\subsubsection{Análise dos níveis de $F B_{2}$ nas amostras de grãos de milho}

Como a determinação dos níveis de $\mathrm{FB}_{2}$ foi uma variável contínua com elevado número de zeros, ajustou-se em um único modelo a proporção de amostras que não continham $\mathrm{FB}_{2}$ e a média de seus níveis quando a amostra continha essa micotoxina.

Notamos que os níveis médios de $\mathrm{FB}_{2}$ (nas amostras positivas para esta fumonisina) variaram em função da região $(\mathrm{p}=0,002)$. Porém, não houve indícios de que os níveis médios de $\mathrm{FB}_{2}$ variaram em função do tratamento $(\mathrm{p}=0,130)$, da interação entre região e tratamento $(\mathrm{p}=0,594)$, da porcentagem de grãos de milho infectados por $F$. verticillioides $(\mathrm{p}=0,897)$, da Aa do milho $(\mathrm{p}=0,996)$, da Aa da cobertura morta $(\mathrm{p}=0,875)$ e da presença de $F$. verticillioides na cobertura morta $(\mathrm{p}=0,703)$. Também não houve indícios de que a proporção de amostras que não continham $\mathrm{FB}_{2}$ tenha se alterado em função de alguma das variáveis consideradas ( $\mathrm{p}>0,07$ para todas as variáveis) (Tabelas 28 e 29).

Tabela 28 - Estimativas e valores-p do ajuste do modelo de regressão Gaussiana inversa inflacionado no zero para a variável "níveis de $\mathrm{FB}_{2}$ no milho".

\begin{tabular}{ccccccc}
\hline Parâmetro & Variável & Nível & Estimativa & $\begin{array}{c}\text { Erro } \\
\text { padrão }\end{array}$ & Valor-p & $\begin{array}{c}\text { Exp. Da } \\
\text { estimat. }\end{array}$ \\
\hline $\begin{array}{c}\text { Média dos } \\
\text { valores } \\
\text { contínuos }\end{array}$ & $\begin{array}{c}\text { Intercepto } \\
\text { Região }\end{array}$ & C. P. & $-1,963$ & 0,646 & 0,002 & 0,140 \\
\hline
\end{tabular}

Tabela 29 - Valores-p das variáveis não incluídas no modelo de regressão Gaussiana inversa inflacionado no zero para a variável "níveis de $\mathrm{FB}_{2}$ no milho".

\begin{tabular}{ccc}
\hline Parâmetro & Variável & Valor-p \\
Média dos & Tratamento & 0,130 \\
Valores & Interação Região e Tratamento & 0,594 \\
Contínuos & Porcentagem de $F$. verticillioides & 0,897 \\
& Aa do milho & 0,996 \\
& Aa da cobertura morta & 0,875 \\
& Presença de $F$. verticillioides na & 0,703 \\
\hline Probabilidade & cobertura morta & 0,358 \\
de assumer & Região & 0,786 \\
o valor 0 & Tratamento & 0,307 \\
& Interação Região e Tratamento & 0,124 \\
& Porcentagem de $F$. verticillioides & 0,432 \\
& Aa do milho & 0,790 \\
& Aa da cobertura morta & 0,071 \\
\hline
\end{tabular}


Observando o valor do exponencial da estimativa na tabela 28 , constatamos que o nível médio de $\mathrm{FB}_{2}$ foi, em média, $86 \%$ menor em Capão Bonito do que em Palmital. 


\section{DISCUSSÃO}

\subsection{Micobiota e Atividade de água das Amostras de Cobertura Morta}

Segundo Costa (1994), há mais de três mil anos antes de Cristo o homem já havia descoberto a importância do "húmus" para aumentar seus índices de produtividade agrícola. O manejo, conservação e aproveitamento da matéria orgânica, tanto quanto a integração das explorações animais e vegetais, eram então considerados de grande importância. Ainda hoje, é muito incipiente a utilização, por parte dos agricultores, das práticas mais adequadas de manejo e conservação da matéria orgânica, como forma de substituição parcial ou total dos adubos químicos (LOURENÇO; MEDRADO, 1998).

Matéria orgânica ou adubo orgânico é todo o produto proveniente de corpos organizados, ou qualquer resíduo de origem vegetal, animal, urbano ou industrial, que apresente elevados teores de componentes orgânicos, compostos de carbono degradável (LOURENÇO; MEDRADO, 1998).

A cobertura morta é feita com materiais orgânicos de diversas origens, sendo mais comumente utilizados os restos vegetais de roçadas, onde são incluidos os utilizados como adubos verdes, restos de culturas comerciais, produto de capineiras, instaladas com esta finalidade, resíduos industriais diversos e vários outros resíduos orgânicos, inclusive lonas plásticas fabricadas para este fim (LOURENÇO; MEDRADO, 1998).

A cobertura com restos de cultura é uma das mais eficientes práticas de controle da erosão, inclusive a eólica. Ela protege o solo contra o impacto das gotas de chuva, evitando a desagregação das partículas (primeiro estágio da erosão) e diminuindo o escorrimento superficial, mitigando o transporte das partículas desagregadas (segundo estágio da erosão) (LOURENÇO; MEDRADO, 1998).

Em estudos sobre aplicação de cobertura morta do solo em cafeeiros novos do Brasil, Medcalf (1956), afirma que a cobertura morta densa contribuiu para um aumento aproximado da ordem de $72 \%$ na produção total. A cobertura morta contribui também para a conservação da água, sendo mais importante nas zonas de precipitação pouco abundante ou mal distribuída (LOURENÇO; MEDRADO, 1998). Para Bertoni e Lombardi Neto (1985), a aplicação de cobertura de palha de capim gordura em cafezal controlou perdas de solo em $65 \%$ e de água em 55\%. Ela também auxilia na diminuição da variação da temperatura do solo, mantendo-a em equilíbrio (LOURENÇO; MEDRADO, 1998). Vidal e Bauman (1996), estudando o efeito de níveis de palha de trigo no microclima do solo sob plantio direto, concluíram que o 
incremento nos níveis de palha de trigo reduziu a temperatura máxima e teve pouco efeito na temperatura mínima do solo. Martin-Neto et al. (1996), em experimentos em latossolo roxo distrófico, em Londrina/PR, mostraram vantagens significativas na utilização do plantio direto (cobertura morta) se comparado com o manejo convencional, no que se refere a estabilização da matéria orgânica do solo. Também há redução na infestação de plantas daninhas, tanto pela influência na quebra de dormência (luz, temperatura e umidade) quanto por alelopatia (LOURENÇO; MEDRADO, 1998). Entretanto, a utilização de cobertura morta pode apresentar perigo de fogo se aplicada sem descontinuidade e também pode propiciar o aumento dos efeitos das geadas (LOURENÇO; MEDRADO, 1998). Segundo Kohnke (1968), a aplicação superficial de resíduos orgânicos resulta ainda numa diminuição do teor de oxigênio no solo.

Em nossa pesquisa, nas amostras de cobertura morta coletadas em dois períodos distintos, Cladosporium spp. foi o fungo mais frequente tanto em Palmital (51,5\% - $1^{\text {a }}$ coleta: 37,8\%; $2^{\mathrm{a}}$ coleta: $\left.65,2 \%\right)$ quanto em Capão Bonito $\left(70,6 \%\right.$ - $1^{\mathrm{a}}$ coleta: $58,4 \% ; 2^{\mathrm{a}}$ coleta: $82,9 \%)$.

Em relação ao gênero Fusarium, $F$. verticillioides foi a espécie mais isolada na região de Palmital nas duas coletas $\left(1^{\mathrm{a}}-17,0 \% / 2^{\mathrm{a}}-6,1 \%\right)$. Já em Capão Bonito, F. verticillioides não foi isolado na $1^{\mathrm{a}}$ coleta, e foi isolado apenas no T4 da $2^{\mathrm{a}}$ coleta $(7,1 \%)$. F. bulbicola foi a espécie mais frequente na $1^{\mathrm{a}}$ coleta $(24,6 \%)$ e $F$. graminearum na $2^{\mathrm{a}}(3,5 \%)$.

Os níveis médios de Aa nas amostras foram distintos nas duas localidades de estudo, sendo de 0,78, em Palmital, e 0,49, em Capão Bonito.

A elevada frequência de Cladosporium spp. nas amostras de cobertura morta pode ser atribuída a elevada a predominância deste fungo no ecossistema brasileiro, principalmente no solo e no ar atmosférico. Além disso, esse gênero fúngico é considerado contaminante universal (GAMBALE, 1998).

Segundo Cahagnier, Melcion e Richard-Molard (1995), o valor mínimo de Aa para o crescimento de $F$. verticillioides é de 0,87 . Em nossa investigação, mesmo com os baixos níveis de Aa constatados nas amostras de cobertura morta, nas duas áreas de estudo, houve o isolamento de $F$. verticillioides e de outras espécies de Fusarium spp. em meio de cultura DG18 (Ágar Base Dicloran Glicerol Cloranfenicol). Este meio de cultura é recomendado para o isolamento de fungos provenientes de substratos de baixa atividade de água (PITT; HOCKING, 2009).

Em nosso estudo, a baixa frequência de isolamento de $F$. poae (Peck) Wollenw. nos restos culturais encontra respaldo na literatura. Produtor de tricotecenos, principalmente 
Toxina T-2, Nivalenol e Diacetoxicirpenol, a citada espécie é pouco isolada em regiões tropicais e subtropicais, porém, frequentemente isolada em cereais e gramíneas cultivados em regiões frias a temperadas (BOTTALICO, 1998; LIU; SUNDHEIM; LANGSETH, 1998; TOTH et al., 1993).

\subsection{Micobiota de Atividade de água das Amostras de Grãos de Milho}

O milho, um dos grãos de cereais mais importantes no mundo, frequentemente é infectado por uma grande variedade de fungos, potencialmente produtores de micotoxinas (SAMAPUNDO et al., 2007; ZHANG et al., 2013).

No presente estudo, $F$. verticillioides foi o fungo mais frequente em ambas as regiões e em todas as coletas [Palmital - 38,6\% na $1^{\mathrm{a}}$ coleta (Safra verão 2010/2011); 70,3\% na $2^{\mathrm{a}}$ coleta (Safra verão 2011/2012) / Capão Bonito - 30,5\% na 1ª coleta (Safra verão 2010/2011); 69,2\% na $2^{\text {a }}$ coleta (Safra verão 2011/2012)]. A atividade de água média das amostras provenientes da região de Palmita foi de 0,90 ( $1^{\text {a }}$ coleta) e 0,92 ( $2^{\text {a }}$ coleta). Em Capão Bonito, a média constatada foi de 0,94 e 0,97 , respectivamente.

A predominância de $F$. verticillioides, principal espécie produtora de fumonisinas, nas duas regiões estudadas, está de acordo com os resultados obtidos por outros pesquisadores, que citam Fusarium spp. como o principal contaminante de grãos de milho em todo o mundo (DAMBOLENA et al., 2010; MILLS, 1989; ZHANG et al., 2013).

No Brasil, estudos apontam $F$. verticillioides, considerado fungo endofítico, como o de maior frequência em grãos de milho recém-colhido e armazenado (ALMEIDA et al., 2000; ALMEIDA et al., 2002; ALMEIDA et al., 2005; ORSI et al., 2000; ROCHA et al., 2009), porém, nosso trabalho revelou frequência de isolamento deste fungo inferior aos trabalhos citados anteriormente.

Alguns estudos têm demonstrado uma redução no isolamento de Fusarium spp., como também da contaminação por fumonisinas em grãos de milho transgênico (PAPST et al., 2005; MUNKVOLD; HELLMICH; RICE, 1999). Em 2002, Bakan et al. compararam a micobiota de grãos de milho $\mathrm{Bt}$ (transgênicos que expressam a toxina Cry1 $\mathrm{Ab}$ ) e de grãos convencionais isolados na França e na Espanha. Os resultados revelaram F. verticillioides como a espécie mais frequente tanto no milho Bt como no convencional, porém, constatou-se massa fúngica 4 a 18 vezes menor no Bt comparado com seu isogênico.

Em nossa investigação, além de $F$. verticillioides, os demais gêneros isolados também foram relatados por outros autores que estudaram a micobiota de grãos de milho, com 
destaque para a espécie $F$. proliferatum, considerada a segunda espécie mais comum no milho e também produtora de fumonisinas (ALBORCH et al., 2012; ALMEIDA et al., 2002; MOSTAFA; KAZEN, 2011; POZZI et al., 1995; ROCHA et al., 2009).

Nas amostras provenientes de Palmital e Capão Bonito, coletadas na safra verão 2011/2012 (2 $2^{\text {a }}$ coleta), o percentual de grãos de milho contaminados com $F$. verticillioides, para todos os tratamentos, esteve entre $56 \%$ e $82 \%$. Tambem o percentual de grãos infectados não variou em função da região e do tratamento, mas sim em função da presença ou ausência desta espécie na cobertura morta $(\mathrm{p}=0,0008)$. Notamos que a chance de um grão conter $F$. verticillioides foi $62 \%$ menor, quando a cobertura morta apresentava contaminação por esse fungo. Desta maneira, em nossa pesquisa, os resultados sugerem que a cobertura morta não foi o principal agente contaminante para o milho em campo.

Em relação à Aa dos grãos, não foi constatada diferença entre os tratamentos, mas sim entre os períodos de coleta. A maior frequência de isolamento de $F$. verticillioides, nas duas coletas e em ambas as regiões estudadas, encontra resposta nos níveis elevados de atividade de água das amostras (Palmital entre 0,90 e 0,92; Capão Bonito entre 0,94 e 0,97). Segundo Woods e Duniway (1986), a Aa ótima para crescimento de $F$. verticillioides é 0,98. Estudo realizado por Marin et al. (1996) mostrou que a germinação de F. verticillioides é marcadamente influenciado pela $\mathrm{Aa}$; seus resultados apontaram que este fungo apresentou maior porcentagem de germinação num menor tempo (24 horas) em uma Aa igual a 0,98. A Aa mais baixa testada por estes autores foi de 0,85 , onde ocorreu crescimento somente após 40 dias.

De acordo com Hurst (2001), vários fatores abióticos influenciam o crescimento fúngico e a presença de micotoxinas nos grãos, destacando-se a Aa e a temperatura como os mais importantes.

\subsection{Identificação das espécies de Fusarium spp. isoladas das amostras de cobertura morta e grãos de milho de ambas as regiões}

Os isolados de Fusarium spp. foram identificados morfologicamente através da visualização das características macroscópicas e microscópicas. Para a confirmação taxonômica, os isolados foram submetidos ao sequenciamento parcial do gene do fator de elongação $1 \alpha$. Este gene, que codifica uma parte essencial da proteína da maquinaria de translação, tem grande utilidade filogenética, sendo altamente informativo para a determinação de espécies de Fusarium. Este gene de cópia única possui alto nível de 
polimorfismo entre as espécies relacionadas, razão pela qual se tornou um marcador de escolha na identificação das espécies de Fusarium (GEISER et al., 2004), fato também constatado em nossa investigação.

Do total das 227 cepas identificadas como $F$. verticillioides, $56,8 \%$ foram isoladas na região de Palmital (11,6\% na cobertura morta; $88,4 \%$ no milho) e 43,2\% na região de Capão Bonito (2,0\% na cobertura morta; $98,0 \%$ em amostras de milho). A maior frequência de $F$. verticillioides nos grãos de milho pode ser atribuída ao caráter endofítico do fungo e aos maiores niveis de umidade dos grãos, comparativamente aos da cobertura morta.

\subsection{Avaliação da metodologia analítica para determinação das fumonisinas $B_{1}$ e $B_{2}$}

As curvas de calibração, utilizadas para a quantificação das fumonisinas $\mathrm{B}_{1}$ e $\mathrm{B}_{2}$, tanto nas análises das amostras de milho quanto para o potencial toxigênico das cepas de $F$. verticillioides, apresentaram-se lineares nas faixas de concentrações. Os coeficientes de correlação foram considerados satisfatórios, já que todos foram maiores que 0,99 .

A recuperação do método foi testada em amostras artificialmente contaminadas com fumonisinas $\mathrm{B}_{1}$ e $\mathrm{B}_{2}$, em diferentes níveis de concentração e em triplicata.

De acordo com o Instituto Nacional de Metrologia (2010), a recuperação expressa a precisão de uma metodologia, sendo estimada pela adição de quantidades conhecidas do analito em uma determinada amostra. Repetitividade avalia a dispersão dos resultados entre ensaios independentes, repetidos de uma mesma amostra, e em condições definidas. Limite de quantificação (LQ) é definido como a menor concentração do analito que pode ser determinada com nível aceitável de precisão.

Para a determinação das fumonisinas nos grãos utilizamos a técnica proposta por Visconti, Solfrizzo e Girolamo (2001). Esta metodologia, de acordo com Shundo e Sabino (2006), tem possibilitado maior especificidade permitindo limites de detecção mais baixos e utilização de menores volumes de solventes.

De acordo com o European Commitee for Standardization (1999), as recuperações para fumonisinas devem situar-se entre 70 a $110 \%$ com desvio padrão relativo $\leq 20$, quando as concentrações variam de 500 a $5000 \mu \mathrm{g} / \mathrm{kg}$, e 60 a $120 \%$ com desvio padrão relativo $\leq 30$, quando a concentração for inferior a $500 \mu \mathrm{g} / \mathrm{kg}$. Portanto, os resultados obtidos na presente investigação, na otimização do método para análise de fumonisinas em grãos de milho, foram considerados satisfatórios. 


\subsection{Determinação de fumonisinas $B_{1}$ e $B_{2}$ nas amostras de grãos de milho}

$\mathrm{Na}$ presente investigação, a análise micotoxicológica das amostras referentes à $1^{\mathrm{a}}$ coleta (Safra verão 2010/2011), em Palmital, revelou a presença de FB ( $\left.\mathrm{FB}_{1}+\mathrm{FB}_{2}\right)$ em 75,0\% das amostras do T1 $(51,0 \mu \mathrm{g} / \mathrm{kg})$ e em $58,3 \%$ do T2 $(84,3 \mu \mathrm{g} / \mathrm{kg})$. Em Capão Bonito, FB foram detectadas em 58,3\% das amostras do T1 $(74,6 \mu \mathrm{g} / \mathrm{kg})$ e em $66,7 \%$ do T2 $(64,9 \mu \mathrm{g} / \mathrm{kg})$, na $1^{\text {a }}$ coleta. Na análise das amostras da $2^{\text {a }}$ coleta (Safra verão 2011/2012), em Palmital, FB foram detectadas em 100\% das amostras de todos os tratamentos (T1: 700,2 $\mu \mathrm{g} / \mathrm{kg}$; T2: 286,8 $\mu \mathrm{g} / \mathrm{kg}$; T3: 904,7 $\mu \mathrm{g} / \mathrm{kg}$; T4: 892,3 $\mu \mathrm{g} / \mathrm{kg}$ ). Já em Capão Bonito, FB foram encontradas em $100 \%$ das amostras dos T1 (110,1 $\mu \mathrm{g} / \mathrm{kg}), \mathrm{T} 2(139,6 \mu \mathrm{g} / \mathrm{kg})$ e T4 $(92,8 \mu \mathrm{g} / \mathrm{kg})$ e em $91,7 \%$ do $\mathrm{T} 3(58,9 \mu \mathrm{g} / \mathrm{kg})$.

Verificamos, em nossa pesquisa, que a detecção de FB nos tratamentos diferiu de acordo com a região, sendo, em média, maior em Palmital do que em Capão Bonito.

Foi constatado que a média dos níveis de $\mathrm{FB}_{1}$ nas amostras de milho variou em função da interação entre região e tratamento $(\mathrm{p}=0,0224)$ e da porcentagem de grãos de milho infectados por $F$. verticillioides $(\mathrm{p}=0,0026)$. Em Capão Bonito $(\mathrm{p}=0,0006)$, o nível médio de $\mathrm{FB}_{1}$ no milho foi menor quando realizada a rotação entre as culturas de soja, trigo e milho (T3) do que quando foi plantado apenas milho em todos os ciclos (T2). Já para Palmital, o oposto foi observado. Vale ressaltar que o nível médio de $\mathrm{FB}_{1}$ nas amostras de milho provenientes de Capão Bonito foi $67 \%$ menor quando realizada rotação entre as culturas de soja, trigo e milho em comparação à monocultura. Este fato concorda com a hipótese de que a monocultura pode aumentar o inóculo do fungo e, consequentemente, aumentar a infecção dos grãos por fumonisinas. Trento, Irgang e Reis (2002), avaliando o efeito da rotação de culturas, da monocultura e da densidade de plantas na incidência de grãos ardidos em milho na região de Passo Fundo (RS), notaram que a maior incidência de grãos ardidos ocorreu em monocultura, com média de 10,02\%, enquanto sob rotação das culturas do milho com soja e azevém, esta foi de 4,8\%. Porém, Smit e Flett (2000), em experimentos realizados na África do Sul, não observaram diferença significativa na severidade da doença Cercosporiose ("grey leaf spot") entre milho cultivado em monocultura ou sob rotação com soja. Os autores consideraram que este resultado pode ser atribuído à capacidade do fungo sobreviver durante dois anos em detritos de milho na superfície do solo e consideraram que a rotação de culturas não é efetiva para controlar a doença sob condições epidêmicas. Este fato pode estar de acordo com os resultados encontrados na região de Palmital, onde não houve indícios de que 
o nível médio de $\mathrm{FB}_{1}$ variou entre os tratamentos, porém não obtivemos acesso às informações sobre as condições epidêmicas da região.

Em relação a $\mathrm{FB}_{2}$, notamos que os níveis médios nas amostras positivas para esta fumonisina variaram apenas em função da região $(p=0,002)$. Nas amostras em que detectouse $\mathrm{FB}_{2}$, ela foi, em média, $86 \%$ menor em Capão Bonito do que em Palmital.

Estudos sobre a ocorrência de $\mathrm{FB}_{1}$ e $\mathrm{FB}_{2}$ em milho recém-colhido no Brasil apontam positividade em $92,3 \%$ e $81 \%$, respectivamente. Nesses estudos, a maioria das amostras revelou uma média de 4.900,0 $\mu \mathrm{g} / \mathrm{kg}$ para $\mathrm{FB}_{1}$ e de 3.900,0 $\mu \mathrm{g} / \mathrm{kg}$ para $\mathrm{FB}_{2}$ (ALMEIDA et al., 2002; HASSEGAWA et al., 2008; HIROOKA et al., 1996; MALLMAN; SANTURIO; DILKIN, 2001; MORENO et al., 2009; ONO et al., 2001; ONO et al., 2004; ONO et al., 2008; ORSI et al., 2000; ROCHA et al., 2009; RODRIGUEZ-AMAYA; SABINO, 2002; VAN DER WESTHUIZEN et al., 2003).

Os níveis médios de atividade de água do milho (na faixa de 0,93) associados à boa adaptação do fungo ao substrato provavelmente favoreceram a presença de $F$. verticillioides e a produção de fumonisinas, embora em baixa frequência de isolamento e abaixo dos níveis citados em outros trabalhos com milho convencional.

Desta forma, salientamos que a prática da rotação de culturas pode ser considerada uma medida importante de controle para os patógenos causadores de podridões da espiga, também conhecidas como "PEs" em regiões não epidêmicas. A utilização de densidade de plantas adequada às condições da lavoura, o controle dos níveis de nitrogênio no solo, o híbrido utilizado e o conhecimento dos ciclos biológicos das espécies de fungos envolvidas com a produção de micotoxinas, também podem contribuir para a redução da incidência de doenças, consequentemente, reduzindo os danos na quantidade e qualidade dos grãos de milho e beneficiando de forma significativa os produtores rurais e o consumidor final (TRENTO, IRGANG; REIS, 2002). Essa prática somada à utilização de milho transgênico, provavelmente foi responsável pela redução do potencial do inóculo de $F$. verticillioides em nosso trabalho e, consequentemente, resultando em níveis de fumonisinas inferiores aos encontrados em outros estudos.

Não existe, até o presente momento, uma legislação global para regular os níveis máximos permitidos de fumonisinas no milho e em produtos processados a partir do mesmo. Entretanto, mais de 90 países apresentam regulamentação própria ou níveis máximos tolerados para algumas micotoxinas, dependendo do tipo de matriz (LINO; SILVA; PENA, 2004). 
No Brasil, em 2011, estipulou-se a recomendação para limites máximos tolerados de $\mathrm{FB}_{1}+\mathrm{FB}_{2}$ para milho de pipoca $(2000 \mu \mathrm{g} / \mathrm{kg})$ e alimentos a base de milho para alimentação infantil $(200 \mu \mathrm{g} / \mathrm{kg})$. A partir de 2012, outros alimentos foram adicionados à resolução, como farinha de milho, creme de milho, fubá, flocos, canjica e canjiquinha, cujo limite máximo tolerado é de $2500 \mu \mathrm{g} / \mathrm{kg}$. Também foram adicionados amido de milho e outros produtos a base de milho, cujo limite máximo tolerado é de $2000 \mu \mathrm{g} / \mathrm{kg}$ (BRASIL, 2011). Em nosso estudo, a análise micotoxicológica das amostras de grãos de milho, provenientes da região de Palmital, revelou que 23,6\% das amostras estavam contaminadas com $\mathrm{FB}\left(\mathrm{FB}_{1}+\mathrm{FB}_{2}\right)$ com valores acima do limite estipulado para alimentos a base de milho para alimentação infantil $(200 \mu \mathrm{g} / \mathrm{kg})$ e 8,3\% estavam contaminadas com níveis acima de $2000 \mu \mathrm{g} / \mathrm{kg}$. Em Capão Bonito, 9,7\% das amostras estavam contaminadas com níveis acima $200 \mu \mathrm{g} / \mathrm{kg}$.

Já está publicado no Diário Oficial da União de 22 de fevereiro de 2011 (Resolução $\mathrm{RDC} \mathrm{N}^{\mathrm{o}}$ - 7) que a partir de janeiro de 2014 , o limite máximo preconizado para $\mathrm{FB}_{1}+\mathrm{FB}_{2} \mathrm{em}$ milho em grão para posterior processamento será de $5000 \mu \mathrm{g} / \mathrm{kg}$. Nessa mesma resolução, consta que, será aplicado a partir de janeiro de 2016, o limite máximo tolerado para $\mathrm{FB}_{1}+$ $\mathrm{FB}_{2}$ em farinha de milho, creme de milho, fubá, flocos, canjica, canjiquinha de $1500 \mu \mathrm{g} / \mathrm{kg}$ e em amido de milho e outros produtos a base de milho de $1000 \mu \mathrm{g} / \mathrm{kg}$ (BRASIL, 2011).

\subsection{Avaliação do potencial toxigênico das cepas de $F$. verticillioides isoladas das amostras de cobertura morta e grãos de milho}

O potencial toxigênico das 227 cepas de $F$. verticillioides, principal espécie produtora de fumonisinas e encontrada com elevada frequência em grãos de milho recém-colhidos e armazenados (NELSON, 1992), verificou-se que 51,1\% (116/227) foram capazes de produzir (com valores acima do limite de quantificação) $\mathrm{FB}_{1}$, e 33,5\% (76/236) produziram ambas as toxinas $\left(\mathrm{FB}_{1}\right.$ e $\left.\mathrm{FB}_{2}\right)$. Os níveis de $\mathrm{FB}_{1}$ variaram de 59,8 a $57.174,1 \mu \mathrm{g} / \mathrm{Kg}$, e os níveis de $\mathrm{FB}_{2}$ variaram de 53,0 a $40.021,9 \mu \mathrm{g} / \mathrm{Kg}$.

De acordo com Proctor et al. (2006), variados perfis toxicológicos de cepas de $F$. verticillioides podem refletir diferenças importantes no risco de contaminações por fumonisinas, com potenciais implicações para a saúde humana e animal, para o comércio internacional, no controle biológico e na compreensão da biossíntese destas micotoxinas. Portanto, um conhecimento prévio da potencialidade da biossíntese de fumonisinas por cepas provenientes de diferentes regiões geográficas pode auxiliar na prevenção do risco de contaminação (COVARELLI et al., 2012). 
Almeida et al. (2005) ressaltou que a presença de fungos toxigênicos no alimento indica uma possível contaminação por micotoxinas. Os riscos dessa contaminação tendem a aumentar se o alimento for um bom substrato para a produção de micotoxinas associados a fatores abióticos que favoreçam essa contaminação.

\subsection{Análise dos fatores climatológicos das duas regiões de estudo}

Dados referentes às temperaturas mínima e máxima $\left({ }^{\circ} \mathrm{C}\right)$ e à quantidade de chuvas por metro quadrado (índice pluviométrico - $\mathrm{mm}$ ) das duas regiões durante todo o período do experimento (outubro/2010 a março/2012) foram analisados. As coletas na região de Palmital foram realizadas nos meses de outubro/2010 ( $1^{\text {a }}$ cobertura morta), fevereiro/2011 (milho safra verão 2010/2011), outubro/2011 (2a cobertura morta) e fevereiro/2012 (milho safra verão 2011/2012). Já em Capão Bonito, as coletas foram realizadas em outubro/2010 $\left(1^{\text {a }}\right.$ cobertura morta), março/2011 (milho safra verão 2010/2011), setembro/2011 (2 ${ }^{\text {a }}$ cobertura morta) e março/2012 (milho safra verão 2011/2012).

Em nossos resultados observamos que, nas amostras de grãos de milho, da primeira para a última coleta, nas duas regiões, a média da frequência de isolamento de $F$. verticillioides aumentou (Palmital - 38,6\% na $1^{\mathrm{a}}$ coleta e $70,3 \%$ na última coleta; Capão Bonito - 30,5\% na $1^{\text {a }}$ coleta e 69,2\% na última coleta), os valores médios de Aa aumentaram (Palmital - 0,90 na $1^{\text {a }}$ coleta e 0,92 na última; Capão Bonito - 0,94 na $1^{\text {a }}$ coleta e 0,97 na última), a média da porcentagem de amostras contaminadas com FB aumentou (Palmital $66,6 \%$ na $1^{a}$ coleta e $100 \%$ na última; Capão Bonito - 62,5\% na $1^{\text {a }}$ coleta e 97,9\% na última) e os níveis médios de FB também aumentaram (Palmital - 67,6 $\mu \mathrm{g} / \mathrm{Kg}$ na $1^{\text {a }}$ coleta e 696,0 $\mu \mathrm{g} / \mathrm{Kg}$ na última; Capão Bonito - 69,7 $\mu \mathrm{g} / \mathrm{Kg}$ na $1^{\mathrm{a}}$ coleta e $100,3 \mu \mathrm{g} / \mathrm{Kg}$ na última).

Os dados referentes aos fatores climatológicos de nossa pesquisa mostraram que, na região de Palmital, da $1^{\mathrm{a}}$ coleta de grãos de milho para a $2^{\mathrm{a}}$ e última, o índice pluviométrico médio diminuiu bruscamente (de 371,4 para 54,0 $\mathrm{mm}$ ) e a temperatura máxima aumentou de 31,3 para 33,6 ${ }^{\circ} \mathrm{C}$. Já em Capão Bonito, o índice pluviométrico e a temperatura máxima aumentaram sutilmente (de 46,1 para $87,8 \mathrm{~mm}$ e de 23,9 para $25,5^{\circ} \mathrm{C}$, respectivamente) da $1^{\mathrm{a}}$ para a última coleta do milho, porém, vale ressaltar que, os dois meses que antecederam a última coleta (janeiro e fevereiro/2012) foram marcados por altos índices de chuvas $(338,3$ $\mathrm{mm}$ e $274,4 \mathrm{~mm}$, respectivamente) e, em fevereiro/2012, a temperatura máxima ultrapassou $28^{\circ} \mathrm{C}$. 
Segundo Miller (2001), F. verticillioides cresce bem em altas temperaturas, acima de $26{ }^{\circ} \mathrm{C}$, de acordo com Reid et al. (1999), e o acúmulo de fumonisinas pode estar associado com períodos de estresse hídrico, danos causados por insetos e o cultivo de híbridos fora de suas áreas de adaptação. De modo geral, o estresse hídrico resulta numa maior infestação por insetos herbívoros no milho, portanto não é possível separar totalmente essas variáveis.

Zhang et al. (2013) acrescentaram que o crescimento de espécies de Fusarium produtoras de fumonisinas e a síntese destas micotoxinas no milho são influenciados por vários fatores ambientais em diferentes áreas geográficas, incluindo o clima, temperatura, umidade e precipitação pluvial, antes e durante o período de colheita, bem como por outros fatores, como infestação de insetos e práticas agrícolas inadequadas. Infecções por fungos do gênero Fusarium e altos níveis de contaminação por fumonisinas são geralmente favorecidos por clima quente durante o período de enchimento de grãos, chuvas durante a colheita e altas temperaturas após a colheita (ALBORCH; BRAGULAT; CABAÑES, 2010; FANDOHAN et al., 2003; ZHANG et al., 2013).

Em nosso estudo, as variações encontradas nos dados climatológicos podem explicar o fato de a região de Palmital apresentar maior frequência de isolamento de $F$. verticillioides, maior a porcentagem de amostras contaminadas com FB e maiores níveis médios de FB comparando os resultados da primeira para a última coleta e com os resultados obtidos em Capão Bonito. 


\section{CONCLUSÕES}

Com base nos objetivos propostos e nas condições de realização deste projeto, conclui-se que:

- Os fungos presentes na cobertura morta provavelmente não foram os principais contaminantes do milho em campo;

- A rotação entre três diferentes culturas (soja, trigo e milho - T3) demonstrou-se eficaz em Capão Bonito, onde, neste tratamento, observamos uma menor frequência de isolamento de $F$. verticillioides, menor porcentagem de amostras contaminadas por fumonisinas (FB) e menor nível médio de FB, comparativamente à monocultura (T2);

- A utilização de milho transgênico Bt provavelmente foi responsável pela redução da frequência de isolamento de $F$. verticillioides e, consequentemente, por níveis de FB abaixo dos encontrados em estudos com milho convencional, apesar de esta espécie ter sido a mais isolada em nossas amostras, demonstrando-se adaptada ao substrato e às condições climáticas das regiões de estudo;

- Das amostras de milho contaminadas com FB, 23,6\% apresentaram níveis de contaminação acima do limite estabelecido pela Legislação Brasileira para alimentação infantil $(200 \mu \mathrm{g} / \mathrm{kg})$ e, 8,3\%, acima de $2000 \mu \mathrm{g} / \mathrm{kg}$. Em Capão Bonito, 9,7\% das amostras estavam contaminadas com níveis acima $200 \mu \mathrm{g} / \mathrm{kg}$;

- $\mathrm{O}$ fato de $84,6 \%$ dos isolados de $F$. verticillioides produzirem fumonisinas sinaliza a possibilidade de uma possível contaminação do milho por estas toxinas;

- Em Palmital, a alta frequência de isolamento de F. verticillioides, de porcentagem de amostras contaminadas com FB e os maiores níveis médios de FB podem ser atribuídos ao estresse hídrico e as temperaturas elevadas constatados na região;

- Concluímos que são necessárias outras pesquisas, incluindo a utilização de sementes geneticamente modificadas mais resistentes e adaptadas ao clima da região de plantio, e a rotação de culturas como métodos para controle das doenças, principalmente em Palmital, onde não foram observados os benefícios da utilização dessa prática de controle. Sugerimos, também, que estudos futuros sobre micobiota e micotoxinas em milho transgênico, utilizando rotação de cultura, sejam realizados em períodos de estudos mais longos. 


\section{REFERÊNCIAS*}

ABAWI, G. S.; WIDMER, T. L. Impact of soil health management practices on soilborne pathogens, nematodes and root diseases of vegetable crops. Appl. Soil Ecol., v. 15, p. 37-47, 2000 .

ABDOLLAHI, A.; BUCHANAN, R. L. Regulation of aflatoxin biosynthesis: induction of aflatoxin production by various carbohydrates. J. Food Sci., v. 46, p. 633-635, 1981.

ALBORCH, L.; BRAGULAT, M. R.; CABAÑES, F. J. Comparison of two selective culture media for the detection of Fusarium infection in conventional and transgenic maize kernels. Lett. Appl. Microbiol., v. 50, p. 270-275, 2010.

ALBORCH, L.; BRAGUlAT, M. R.; CASTELlA, G.; ABARCA, M. L.; CABAÑES, F. J. Mycobiota and mycotoxin contamination of maize flours and popcorn kernels for human consumption commercialized in Spain. Food Microbil., v. 32, p. 97-103, 2012.

ALMEIDA, A. P.; CORRÊA, B.; MALlOZZI, M. A. B.; SAWAZAKI, E.; ORTEGA, E. M. Mycoflora and aflatoxin/fumonisin production by fungal isolates from freshly harvested corn hybrids. Braz. J. Microbiol., v. 31, p. 321-326, 2000.

ALMEIDA, A. P.; FONSECA, H.; FANCELLI, A. L.; DIREITO, G. M.; ORTEGA, E. M.; CORREAA, B. Mycoflora and fumonisin contamination in Brazilian corn from sowing to harvest. J. Agric. Food Chem., v.50, n. 13, p. 3877-3882, 2002.

ALMEIDA, A. P.; SABINO, M.; FONSECA, H.; CORRÊA, B. Milho recém-colhido no Brasil: interação da microbiota fúngica, fatores abióticos e ocorrência de micotoxinas. Rev. Inst. Adolfo Lutz, v. 64, p. 1-9, 2005.

AOYAMA, K.; NAKAJIMA, M.; TABATA, S.; EIICHI, I.; TANAKA, T.; NORIZUKI, H.; ITOH, Y.; FUJITA, K.; KAI, S.; TSUTSUMI, T.; TAKAHASHI, M.; TANAKA, H.; IIZUKA, S.; OGISO, M.; MAEDA, M.; YAMAGUCHI, S.; SUGIYAMA, K. I.; SUGITAKONISHI, Y.; KUMAGAI, S. Four-year surveillance for ochratoxin A and fumonisins in retail foods in Japan. J. Food Prot., v. 73, p. 344-352, 2010.

BAKAN, B.; MELCION, D.; RICHARD-MOLARD, D.; CAHAGNIER, B. Fungal growth and Fusarium mycotoxin content in isogenic traditional maize and genetic modified maize grown in France and Spain. J. Agric. Food Chem., v. 50, p. 728-731, 2002.

BENSON, G. O.; PEARCE, R. B. Corn perspective and culture. In: WATSON, S. A. et al. Corn: chemistry and technology. St. Paul: Elsevier, 1987. p. 1-28.

* De acordo com:

ASSOCIAÇÃO BRASILEIRA DE NORMAS TÉCNICAS. NBR 6023: informação e documentação: referências: elaboração. Rio de Janeiro, 2002. 
BERJAK, P. Report of seed storage committee working group on the effects of storage fungi on seed viability. 1980-1983. Seed Sci. \& Technol., v. 12, p. 233-253, 1984.

BERTONI, J.; LOMBARDI NETO, F. Conservação do solo. Piracicaba: Livroceres Ltda, 1985. $368 \mathrm{p}$.

BOONZAAIJER, G.; VAN OSENBRUGGEN, W. A.; KLEINNIJENHUIS, A. J.; VAN DONGEN, W. D. An exploratory investigation of several mycotoxins and their natural occurrence in flavor ingredients and spices, using a multi-mycotoxin LC-MS/MS method. World Mycotoxin J., v.1, p. 167-174, 2008.

BOTTALICO, A. Fusarium diseases of cereal: species complex and related mycotoxin profiles, in Europe. J. Plant Pathol., v. 80, n. 2, p. 85-103, 1998.

BOTTINI, A. T.; GILCHRIST, D. G. Phytotoxins. I. A. 1-aminodimethylheptadecapentol from Alternaria alternata f. sp. lycopersici. Tetrahedron Lett., v. 22, n.29, p. 2719-2722, 1981.

BOULDER, D. Insect pest control by copying nature using genetically engineered crops. Phytochemistry, v. 34, p. 1453-1466, 1993.

BRASIL. Resolução - RDC $\mathrm{n}^{0}$ 7, de 18 de Fevereiro de 2011. Diário Oficial da União, Brasília, DF, 22 de fev. 2011. Seção 1, p. 72-73.

BULLERMAN, L. B. Significance of mycotoxins to food safety and human health. J. Food Prot., v. 42, n. 1, p. 65-86, 1979.

BU'LOCK, J. D. Mycotoxins as secondary metabolities. In: STEYN, P. S. (Ed.). The biosynthesis of mycotoxins. New York: Academy Press, 1980. p. 1-16.

CAHAGNIER, B.; MELCION, D.; RICHARD-MOLARD, D. Growth of Fusarium moniliforme and its biosynthesis of fumonisin $\mathrm{B}_{1}$ on maize grain as a function of different water activities. Lett. Appl. Microbiol., v. 20, p. 247-51, 1995.

CALEGARI, A.; MONDARDO, A.; BULISANI, E.A.; COSTA, M.B.B.; MIYASAKA, S.; AMADO, T.J. Aspectos gerais da adubação verde. In: COSTA, M.B.B.; CALEGARI, A.; MONDARDO, A. et al. Adubação verde no sul do Brasil. 2. ed. Rio de Janeiro: ASPTA, 1992. p. 1-56.

CAMPBELL, C.; STOLOFF, L. Implication of mycotoxins for human health. J. Agric. Food Chem., v. 22, p. 1006-1015, 1974.

CARNEIRO, A. A.; GUIMARÃES, C. T.; VALICENTE, F. H.; WAQUIL, J. M.; VASCONCELOS, M. J. V.; CARNEIRO, N. P.; MENDES, S. M. Milho Bt: Teoria e prática da produção de plantas transgênicas resistentes a insetos praga. Embrapa milho e sorgo, Sete Lagoas, 2009. 26 p. (Circular Técnica, 135).

CARRATÙ, M. R.; CASSANO, T.; COLUCCIA, A.; BORRACCI P.; CUOMO, V. Antinutritional effects of fumonisin $\mathrm{B}_{1}$ and pathophysiological consequences. Toxicology Lett., v. 140, p. 459-463, 2003. 
CASA, R. T.; REIS, E. M. Doenças na cultura do milho. In: FANCELLI, A. L.; DOURADO, D. NETO. (Ed.). Milho: estratégias de manejo e alta produtividade. Piracicaba, Escola Superior da Agricultura "Luiz de Queiroz", Departamento da Produção Vegetal, 2003. p. 118.

CASTRO, A. P. Perspectivas da utilização do gene $b t$ para o controle de insetos-praga do arroz no Brasil. Embrapa arroz e feijão. Santo Antônio de Goiás, 2008. 23 p. (Documentos, 232).

CHAGAS, E.; ARAÚJO, A. P.; TEIXEIRA, M.G.; GUERRA, J. G. M. Decomposição e liberação de nitrogênio, fósforo e potássio de resíduos da cultura do feijoeiro. Rev. Bras. Ciênc. Solo, v. 31, n. 4, p. 723-729, 2007.

CHASIN, A. A. M.; CHASIN, M.; SALVADORI, M. C. Validação de métodos cromatográficos em análises toxicológicas. Braz. J. Pharm. Sci., v. 30, n. 2, p. 49-53, 1994.

CIEGLER, A. Fungi that produce mycotoxins: condition and occurrence. Mycopathology, v. 65, p. 5-11, 1978.

CIRILLO, T.; RITIENI, A.; GALVANO, F.; COCCHIERI, R. A. Natural co-occurrence of deoxynivalenol and fumonisins $\mathrm{B}_{1}$ and $\mathrm{B}_{2}$ in Italian marketed foodstuffs. Food Add. Contam., v. 20, p. 566-571, 2003.

CLEVSTROM, G. Studies of fungi flora of plants and feeds: the influence of formic acid on growth and aflatoxin production in Aspegillus flavus. Sweden, Upsala, 1986. p. 11-46.

COMISSÃO TÉCNICA NACIONAL DE BIOSSEGURANÇA (CTNBIO). Resolução CNBS $\mathbf{N}^{\circ}$ 3, de 5 de março de 2008. 2008. Disponível em: <http://www.ctnbio.gov.br/index.php/content/view/11445.html>. Acesso em: 20 nov. 2013.

COMPANHIA NACIONAL DE ABASTECIMENTO (CONAB). Acompanhamento da Safra Brasileira de Grãos 2011/2012 - $\mathbf{8}^{\mathbf{o}}$ levantamento, 2012. Disponível em: <http://www.cnpt.embrapa.br/conab/levantamento.pdf.> Acesso em: 20 nov. 2013.

COMPANHIA NACIONAL DE ABASTECIMENTO (CONAB). Acompanhamento da Safra Brasileira de Grãos 2013/2014 - $\mathbf{2}^{\mathbf{o}}$ levantamento, 2013. Disponível em: <http://www.conab.gov.br/conteudos.php?a=1253\&t.> Acesso em: 20 nov. 2013.

CORRÊA, B.; GALHARDO, M.; COSTA, E. O.; SABINO, M. Distribution of molds and aflatoxins in dairy cattle feeds and raw milk. Rev. Microbiologia, v. 28, p. 279-283,1997.

COSTA, M. B. V. da. Adubação orgânica: nova síntese e novo caminho para a agricultura. São Paulo: Ícone Editora, 1994. 102 p.

COSTA, J. T. A.; SILVA, L. A. da; MELO, F. I. O. Efeitos do turno de rega e cobertura morta na cultura do alho na serra da Ibiapaba, Ceará: I. Umidade e temperatura do solo. Ciên. Agron., Fortaleza, v. 28, p. 70-84, 1997.

COSTA, D. M. A.; MELO, H. N. S.; FERREIRA, S. R. Eficiência da Cobertura Morta na retenção de Umidade no Solo. Holos, Natal, v. 23, n. 1, p. 59-69, 2007. 
COVARELLI, L.; STIFANO, S.; BECCARI, G.; RAGGI, L.; LATTANZIO, V. M. T.; ALBERTINI, E. Characterization of Fusarium verticillioides strains isolated from maize in Italy: Fumonisin production, pathogenicity and genetic variability. Food Microbiol., v. 31, p. 17-24, 2012.

DAMBOLENA, J. S.; LÓPEZ, A. G.; RUBINSTEIN, H. R.; ZYGADLO, J. A. Effects of menthol stereoisomers on the growth, sporulation and fumonisin $\mathrm{B}_{1}$ production of Fusarium verticillioides. Food Chem., v. 123, p. 165-170, 2010.

DEGOLA, F.; BERNI, E.; DALL'ASTA, C.; SPOTTI, E.; MARCHELLI, R.; FERRERO, I.; RESTIVO, F. M. A multiplex RT-PCR approach to detect aflatoxigenic strains of Aspergillus flavus. J. Appl. Microbiol., v. 103, p. 409-441, 2007.

DELP, R. B.; STEWELL, L. J.; MAROIS, J. J. Evaluation of field sampling techniques for estimation of disease incidence. Phytopathology, v. 76, p. 1299-1305, 1986.

DESAI, K.; SULLARDS, M. C.; ALLEGOOD, J.; WANG, E.; SCHMELZ, E. M.; HARTL, M.; HUMPF, H-U.; LIOTTA, D. C.; PENG, Q.; MERRILL, J. R. A. H. Fumonisins and fumonisin analogs as inhibitors of ceramide synthase and inducers of apoptosis. Biochim. Biophys. Acta, v. 1585, p. 188-192, 2002.

DILKIN, P.; MALLMAN, C. A.; ALMEIDA, C. A. A.; CORRÊA, B. Robotic automated clean-up for detection of fumonisins $\mathrm{B}_{1}$ and $\mathrm{B}_{2}$ in corn and corn-based feed by highperformance liquid chromatography. J. Chrom. A, v. 965, p. 151-157, 2001.

DI MAVUNGU J. D.; MONBALIU, S.; SCIPPO, M-L.; MAGHUIN-ROGISTER, G.; SCHNEIDER Y-J.; LARONDELLE, Y.; CALLEBAUT, A.; ROBBENS, J.; VAN PETEGHEM, C.; DE SAEGER, S. LC-MS/MS multi-analyte method for mycotoxin determination in food supplements. Food Addit Contam A., v. 26, p. 885-895, 2009.

DITCHFIELD, C. Estudo dos métodos para a medida da atividade de água. 2000. 195 f. Dissertação (Mestrado em Engenharia) - Escola Politécnica, Universidade de São Paulo, 2000.

DUVICK, J. Prospects for reducing fumonisin contamination of maize through genetic modification. Environm. Health Perspect., v. 109, p. 337-342, 2001.

EMPRESA BRASILEIRA DE PESQUISA AGROPECUÁRIA (EMBRAPA). Sistema de produção de uvas rústicas para processamento em regiões Tropicais do Brasil - Manejo da vegetação e cobertura, 2005. Disponível em: $<\mathrm{http}$ ://sistemasdeproducao.cnptia.embrapa.br/FontesHTML/Uva/UvasRusticasParaProcessa mento/manejo.htm.> Acesso em: 21 nov. 2013.

EMPRESA BRASILEIRA DE PESQUISA AGROPECUÁRIA (EMBRAPA). Zoneamento agrícola - Época de plantio de milho, 2009. Disponível em: <http://www.cnps.embrapa.br/publicacoes/milho/zoneamento.htm.> Acesso em: 21 nov. 2013.

EMPRESA BRASILEIRA DE PESQUISA AGROPECUÁRIA (EMBRAPA). Rotação de culturas, 2010. In: Embrapa - Informações técnicas para Trigo e Triticale - Safra 2010. 
Disponível em: <http://www.cnpt.embrapa.br/culturas/trigo/indicacoes_tecnicas_ Safra2010.pdf.> Acesso em: 21 nov. 2013.

EUROPEAN COMMITTEE FOR STANDARDIZATION (CEN). CEN/TC 275/wgs Food Analysis - Biotoxins- Criteria of Analytical Methods of Mycotoxins. CEN Report CR 13S0S, Berlin, Germany, 1999, 10p.

FANCELLI, A. J. Plantas alimentícias: guia para aula, estudos e discussão. Piracicaba: Esalq, 1986. 13 p.

FANDOHAN, P.; HELL, K.; MARASAS, W. F. O.; WINGFIELD, M. J. Infection of maize by Fusarium species and contamination with fumonisin in Africa. Afr. J. Biotechnol., v. 2, p. 570-579, 2003.

FANTIN, G. M.; DUARTE, A. P.; MELlO, E. A.; PIEDADE, R. C.; BARROS, V. L. N. P.; SILVA, B. M. P.; BULGARELLI, C. A. Efeito da rotação de culturas na severidade das manchas foliares de Cercospora e de Bipolaris maydis do milho. In: CONGRESSO NACIONAL DE MILHO E SORGO, 29., 2012, Águas de Lindóia. Anais... Águas de Lindóia, 2012. p. 742-748.

FREDERIKSEN, R. A. Compendium of sorghum diseases. APS: Press, 1996. p. 1-41.

FRISVAD, J. C.; SANSON, R. A. Filamentous fungi in Foods and Feeds: Ecology spoilage and mycotoxins production. In: DILIP, K. et al. Handbook of applied mycology: food and feeds. New York: Marcel Dekker, 1991.

FUTUYMA, D. J. Biologia evolutiva. Ribeirão Preto: Sociedade Brasileira de Genética, 1997. p. 232-324.

GALINDO, J. J.; ABAWI, G. S.; THURSTON, H. D.; GALVEZ, G. Effect of mulching on web blight of beans in Costa Rica. Phytopathology, v. 73, p. 610-615, 1983.

GAMBALE, W. Fungos contaminantes. In: ZAITZ, C.; CAMPBELL, I.; MARQUES, S. A.; RUIZ, L. R.; SOUZA, V. M. (Ed.). Compendio de micologia medica. São Paulo: Medsi Editora Medica e Cientifica Ltda, 1998. p. 113-121.

GAZZOTTI, T.; LUGOBONI, B.; ZIRONI, E.; BARBAROSSA, A.; SERRAINO, A.; PAGLIUCA, G. Determination of fumonisin $B_{1}$ in bovine milk by LC-MS/MS. Food Control., v. 20, p. 1171-1174, 2009.

GEISER, D. M.; JIMENEZ-GASCO, M. M.; KANG, S.; MAKALOWSKA, I.; VEERARAGHAVAN, N.; WARD, T. J.; ZHANG, N.; KULDAU, G. A.; O'DONNELL, K. FUSARIUM-ID v. 1.0: A DNA sequence database for identifying Fusarium. Eur. J. Plant Pathol., v.110, p. 473-479, 2004.

GELDERBLOM, W. C.; JASKIEWICZ, K.; MARASAS, W. F. O.; THIEL, P. G.; HORAK, R. M.; VLEGGAAR, R.; KRIEK, N. P. Fumonisins - novel mycotoxins with cancerpromoting activity produced by Fusarium moniliforme. Appl. Environ. Microbiol., v. 54, p. 806-811, 1988. 
GELVIN, S. B. Agrobacterium-mediated plant transformation: the biology behind the "genejockeying” tool. Microb. Mol. Biol. Reviews, v. 67, n. 1, p. 16-37, 2003.

GIBBON, B.; LARKINS, B. A. Molecular genetics approaches to developing quality protein maize. Trends Genet., v. 21, n. 4, p. 227-233, 2005.

GLOBO RURAL. Milho sai da sombra da soja na safra 2011/2012. Mil e uma utilidades I Derivados de alto valor atendem a indústrias em diversos ramos de atuação. 2012. Disponível em: $\quad$ http://revistagloborural.globo.com/Revista/Common/0,ERT262560-18283,00.html.> Acesso em: 20 novembro 2013.

GOLDBLATT, L. A. Implications of mycotoxins. Clin. Toxicol., v. 5, p. 453-458, 1972.

GONZÁLEZ, H. H. L.; RESNIK, S. L.; PACIN, A. M. Mycoflora of freshly harvested flint corn from Northwestern Provinces in Argentina. Mycopathologia, v. 155, p. 207-211, 2003.

HAMMOND, B. G.; CAMPBELl, K. W.; PILCHER, C. D.; DEGOOYER, T. A.; ROBINSON, A. E.; MCMILLEN, B. L.; SPANGLER, S. M.; RIORDAN, S. G.; RICE, L. G.; RICHARD, J. L. Lower fumonisin mycotoxin levels in the grain of Bt corn grown in the United States in 2000-2002. J. Agric. Food Chem., v. 52, p. 1390-1397, 2004.

HASSEGAWA, R. H.; FONSECA, H.; FANCELLI, A. L.; SILVA, V. N.; SCHAMMASS, E. A.; REIS, T. A.; CORREAA, B. Influence of macro - and micronutrient fertilization on fungal contamination and fumonisin production in corn grains. Food Control, v. 19, p. 36-43, 2008.

HESSELTINE, C. W. Coditions leading to micotoxin contamination of foods and feeds. In: RODRICKS, J. V. Mycotoxins and other fungal related food problems. Washington: American Chemical Society, 1976. v. 149, p. 1-22.

HIROOKA, E. Y.; YAMAGUCHI, M. M.; AOYAMA, S.; SUGIURA, Y.; UENO, Y. The natural occurrence of fumonisins in Brazilian corn kernels. Food Addit. Contam., v. 13, p. 173-183, 1996.

HOUSBECK, M. K; PENNYPACKER, S. P.; STEVENSON, R. E. The effect of platic mulch and forced heated air on Botrytis cinerea on geranium stock plants in a research greenhouse. Plant Disease, v. 80, p. 170-173, 1996.

HURST, C. J. Manual of environmental microbiology. Washington, DC: American Society for Microbiology, 2001. 1158 p.

HWANG, S. F.; AHMED, H. U.; GOSSEN, B. D.; KUTCHER, H. R.; BRANDT, S. A.; STRELKOV, S. E.; CHANG, K. F.; TURNBULL, G. D. Effect of crop rotation on soil pathogen population dynamics and canola seedling establishment. Plant Pathol. J., v. 8, p. 106-112, 2009.

INTERNATIONAL AGENCY FOR RESEARCH ON CANCER (IARC). Some naturally occurring substances: food items and constituents, heterocyclic aromatic amines and mycotoxins. Monographs on the evaluation of carcinogenic risks to humans. Lyon, 1993. v. 56, p. 445-446. 
INSTITUTO NACIONAL DE METROLOGIA, NORMALIZAÇÃO E QUALIDADE INDUSTRIAL (INMETRO). Orientações sobre validação de métodos de ensaios químicos. Revisão: 03, 2010. 20 p.

JAMES, C. Global status of commercialized Biotech/GM Crops: 2007. 2007. Disponível em: <http://www.isaaa.org/resources/publications/briefs/37/executivesummary/default.html>. Acesso em: 19 nov. 2013.

JAMES, C. Global status of commercialized biotech/GM crops: 2010. 2010. Disponível em: <http://www.isaaa.org/resources/publications/briefs/42/>. Acesso em: 19 nov. 2013.

JAY, J. M. Microbiologia Moderna de Los Alimentos. 3. ed. Zaragoza: Editorial Acribia, 1994. $753 \mathrm{p}$.

JONES, C. W.; MCCARTER, S. M. Etiology of tomato fruit rots and evaluation of cultural and chemical treatments for their control. Phytopathology, v. 64, p. 1204-1208, 1974.

JOUANIN, L.; BONADÉ-BOTTINO, M.; GIRARD, C.; MORROT, G.; GIBAND, M. Transgenic plants for insect resistence - review. Plant Science, v. 131, p. 1-11, 1998.

KARBANCIOGLU-GULER, F.; HEPERKAN D. Natural occurrence of fumonisin $\mathrm{B}_{1}$ in dried figs as an unexpected hazard. Food Chem. Toxicol., v. 47, p. 289-292, 2009.

KOHNKE, H. Soil Phisics. Tata. New Delhi: McGraw-Hill, 1968. 224 p.

KPODO, K.; THRANE, U.; HALD, B. Fusarium and fumonisins in maize from Ghana and their co-occurrence with aflatoxins. Int. J. Food Microbiol., v. 61, p. 147-157, 2000.

KNUDSEN, P. B.; MOGENSEN, J. M.; LARSEN, T. O.; NIELSEN, K. F. Occurrence of fumonisins $B_{2}$ and $B_{4}$ in retail raisins. J. Agric. Food Chem., v. 59, n. 2, p. 772-776, 2011.

LABUDA, R.; TANCINOVA, D.; HUDEC, K. Identification and enumeration of Fusarium species in poultry feed mixtures from Slovakia. Ann. Agric. Environ. Med., v. 10, p. 61-66, 2003.

LACEY, J.; MAGAN, N. Fungi in cereal grain: their occurrence and water and temperature relations. In: CHELKOWSKI, J. (Ed.). Cereal grain: mycotoxins, fungi and quality in drying and storage. Amsterdam: Elsevier Science, 1991. p. 77-118.

LESLIE, J. F. Introductory biology of Fusarium moniliforme. In: JACKSON, L. S.; DE VRIES, J. W.; BULLERMAN, L. B. (Ed.). Fumonisins in food. New York: Plenum Press, 1996. p. 153-164.

LESLIE, J. F.; KLEIN, K. K. Female fertility and mating type effects on effective population size and evolution in filamentous fungi. Genetics, v. 144, p. 557-567, 1996.

LESLIE, J. F.; ZELLER, K. A.; SUMMERELL, B. A. Icebergs and species in populations of Fusarium. Physiol. Mol. Plant Path., v. 59, p. 107-117, 2001. 
LESLIE, J. F.; SUMMERELL, B. A. The Fusarium laboratory manual. Iowa: Blackwell Publishing, 2006. 388 p.

LILLEHOJ, E.B.; ZUBER, M. S. Distribution of toxin-producing fungi in nature maize kernel from diverse environments. Trop. Sci., v. 28, p. 19-24, 1988.

LINO, C. M.; SILVA, L. J. G.; PENA, A. S. Fumonisinas: presença em alimentos, implicações na saúde e aspectos legislativos. Rev. Port. Cien. Vet., v. 99, p. 181-192, 2004.

LIU, Q.; LIU, G.; LIU, H. Investigation into status of contamination of strong carcinogen fumonisin in peanut, corn and their products and their rapid detection. Zhongguo Redai Yixue. 8:1906-1908, [in Chinese]. Chem. Abstr., v. 152, p. 285504j, 2008.

LIU, W.; SUNDHEIM, L.; LANGSETH, W. Trichothecene production and the relationship to vegetative compatibility groups in Fusarium poae. Mycopathologia, v. 140, p. 105-114, 1998.

LOGUERCIO, L. L.; CARNEIRO, N. P.; CARNEIRO, A. A. Milho Bt: Alternativa biotecnológica para o controle biológico de insetos-praga. Biotec. Cien. Desenvolv., Uberlândia, v. 4, n. 24, p. 46-52, 2002.

LOGRIECO, A.; FERRACANE, R.; HAIDUKOWSKY, M.; COZZI, G.; VISCONTI, A.; RITIENI, A. Fumonisin $\mathrm{B}_{2}$ production by Aspergillus niger from grapes and natural occurrence in must. Food Addit. Contam. A., v. 26, p. 1495-1500, 2009.

LOGRIECO, A.; FERRACANE, R.; VISCONTI, A.; RITIENI, A. Natural occurrence of fumonisin $B_{2}$ in red wine from Italy. Food Addit. Contam. A., v. 27, p. 1136-1141, 2010.

LÓPEZ-OVEJERO, R. F.; CHRISTOFFOLETI, P. J.; NICOLAI, M.; BARELA, J. F. Manejo de plantas daninhas na cultura do milho. In: FANCELLI, A. L.; DOURADO-NETO, D. (Eds.). Milho: estratégias de manejo para alta produtividade. Piracicaba: Escola Superior da Agricultura "Luiz de Queiroz", Departamento da Produção Vegetal, 2004. p. 47-79.

LOURENÇO, R. S.; MEDRADO, M. J. S. Cobertura morta na produção da erva-mate. Colombo: EMBRAPA-CNPF, 1998. 15 p. (EMBRAPA-CNPF. Circular Técnica, 30).

MALLMAN, C. A.; SANTURIO, J. M.; DILKIN, P. Fumonisin $B_{1}$ in cereals and feeds from southern Brazil. Arquivos do Instituto Biológico, v. 68, n.1, p.41-45, 2001.

MANJULA, K.; HELL, K.; FANDOHAN, P.; ABASS, A.; BANDYOPADHYAY, R. Aflatoxin and fumonisin contamination of cassava products and maize grain from markets in Tanzania and republic of the Congo. Toxin Rev., v. 28, p. 63-69, 2009.

MARASAS, W. F. O. Fumonisins: history, world-wide occurrence and impact, 1996. In: Fumonisins in food; Advances in experimental medicine and biology, v. 392, JACKSON, L.S., DE VRIES, J.W., BULLERMAN, L.B., Eds; Plenum Press; New York, N.Y.; pp. 1-18.

MARASAS, W. F. O. Discovery and occurrence of the fumonisins: a historical perspective. Environ. Health Persp., v. 109, p. 239-243, 2001. Suppl. 2. 
MARÍN, S.; SANCHIS, V.; TEIXIDÓ, A.; SÁENZ, R.; RAMOS, A. J.; VIÑAS, I.; MAGAN, N. Water and temperature relations and microconidial germination of Fusarium moniliforme and F. proliferatum from maize. Can. J. Microbiol., v. 42, p. 1045-1050, 1996.

MARIN, S.; MAGAN, N.; RAMOS, A. J.; SANCHIS, V. Fumonisin producing strains of Fusarium: a review of their ecophysiology. J. Food Prot., v. 67, p. 1792-1805, 2004.

MARQUES, D. O que você precisa saber sobre transgênicos. 2009. In: EMBRAPA. O milho Bt no Brasil: a situação e a evolução da resistência de insetos. Embrapa milho e sorgo. Sete Lagoas, 2011. (Documentos, 133).

MARTIN-NETO, L.; MIYAZAWA, M.; BONAGAMBA, T.; COLNAGO, L. A.; PANEPUCCI, Y.; VIEIRA, E. M. Análises espectroscópica e química da matéria orgânica de um latossolo roxo sob manejo convencional e plantio direto. In: CONGRESSO BRASILEIRO DE PLANTIO DIRETO PARA UMA AGRICULTURA SUSTENTÁVEL, 1. 1996, Ponta Grossa, PR. Anais... Ponta Grossa, 1996. p. 86-88.

MARTINS, M. L.; MARTINS, H. M.; BERNARDO, F. Fumonisins $\mathrm{B}_{1}$ and $\mathrm{B}_{2}$ in black tea and medicinal plants. J. Food Prot., v. 64, p. 1268-1270, 2001.

MEDCALF, J.C. Estudos preliminares sobre aplicação de cobertura morta em cafeeiros novos do Brasil. New York: IBEC Research Institute, 1956. 59 p.

MENEZES, L.; CUNHA, J.; BISINOTTO, F.; ATTIE, J. Relatório biotecnologia. Céleres, p. $1-7,2011$.

MILLER, J. R. Epidemiology of Fusarium ear diseases of cereals. In: MILLER, J. D.; TRENHOLM, H. L. (Ed.). Mycotoxins in Grain. St. Paul: Eagan Press, 1994. p. 19-36.

MILLER, J. D. Factors that affect the occurrence of fumonisin. Environ. Health Perspect., v. 109, p. 321-324, 2001. Suppl. 2.

MILLS, J. T. Ecology of mycotoxigenic Fusarium species on cereal seeds. J. Food Protec., v. 52, p. 737-742, 1989.

MISSMER, S. A.; SUAREZ, L.; FELKNER, M.; WANG, E.; MERRILL, A. H. JR.; ROTHMAN, K. J.; HENDRICKS, K. A. Exposure to fumonisins and the occurrence of neural tube defects along the Texas-Mexico border. Environ. Health Perspect., v. 114, p. 237-241, 2006.

MIYASAKA, S. C.; HOLLYER, J. R.; KODANI, L. S. Mulch and compost effects on yield and corm rots of taro. Field Crop. Res., v. 71, n. 2, p. 101-112, 2001.

MOGENSEN, J. M.; FRISVAD, J. C.; THRANE, U.; NIELSEN, K. F. Production of fumonisin $\mathrm{B}_{2}$ and $\mathrm{B}_{4}$ by Aspergillus niger on grapes and raisins. J. Agric. Food Chem., v. 58, p. $954-958,2010$.

MOGENSEN, J. M.; LARSEN, T. O.; NIELSEN, K. F. Widespread occurrence of the mycotoxin fumonisin $B_{2}$ in wine. J. Agric. Food Chem., v. 58, p. 4853-4857, 2010. 
MORENO, E. C.; GARCIA, G. T.; ONO, M. A.; VIZONI, E.; KAWAMURA, O.; HIROOKA, E. Y.; ONO, E. Y. S. Co-occurrence of mycotoxins in corn samples from the Northern region of Paraná State, Brazil. Food Chem., v. 116, p. 220-226, 2009.

MOSTAFA, A.; KAZEN, S. Fungi associated with harvested corn grains of Golestan province in Iran. Annals Biolog. Res., v. 2, n. 5, p. 681-668, 2011.

MOURA, P. A. M.; OLIVEIRA, A. C. S. Aspectos econômicos da cultura do milho. Inf. Agropec., v. 6, n. 72, p. 3-5, 1980. Suppl.

MUNKVOLD, G. P.; MCGEE, D. C.; CARLTON, W. M. Importance of different pathways for maize kernel infection by Fusarium moniliforme. Phytopathology, v. 87, p. 209-217, 1997.

MUNKVOLD, G. P.; HELLMICH, R. L.; SHOWERS, W. B. Reduced Fusarium ear rot and symptomless infection in kernels of maize genetically engineered for European corn borer resistance. Phytopathology, v. 87, p. 1071-1077, 1997.

MUNKVOLD, G. P.; DESJARDINS, A. E. Fumonisins in maize - Can we reduce their occurrence? Plant Dis., v. 81, n. 6, p. 556-565, 1997.

MUNKVOLD, G. P.; HELlMICH, R. L.; RICE, L. G. Comparison of fumonisina concentration in kernels of transgenic Bt maize hybrids and nontransgenic hybrids. Plant Dis., v. 83, p. 130-138, 1999.

MUSCARELLA, M.; MAGRO, S. L.; NARDIELLO, D.; PALERMO, C.; CENTONZE D. Development of a new analytical method for the determination of fumonisins $B_{1}$ and $B_{2}$ in food products based on high performance liquid chromatography and fluorimetric detection with post-column derivatization. J. Chromatogr. A., v. 1203, p. 88-93, 2008.

MUZILli, O. Princípios e perspectivas de expansão. In: Plantio direto no estado do Paraná. Londrina: IAPAR, 1981. p.11-70.

NELSON, P. E.; TOUSON, T. A.; MARASAS, W. F. O. Fusarium species. An illustrated manual for identification. Pennsylvania, University Press, 1983. 193 p.

NELSON, P. E.; PLATTNER, R. D.; SHACKELFORD, D. D.; DESJARDINS, A. E. Production of fumonisins by Fusarium moniliforme strains from various substrates and geographic areas. Appl. Environm. Microbiol., v. 57, n. 8, p. 2410-2412, 1991.

NELSON, P. E. Taxonomy and biology of Fusarium moniliforme. Mycopathologia, v. 117, p. 29-36, 1992.

NETER, J.; KUTNER, M. K.; NACHTSHEIM, C. J.; WASSERMAN, W. Applied linear statistical models. 4 ed. Irwin: Chicago, 1996.

NIRENBERG, H. 1976. Untersuchungen uber die morphologische und biologische Differenzierung in Die Fusarium-Sektion Liseola. In: PITT, J. I.; HOCKING, A. D. Fungi and food spoilage. 3rd ed. New York: Springer, 2009. p. 121. 
NJOBEH, P. B.; DUTTON, M. F.; KOCH, S. H.; CHUTURGOON, A. A.; STOEV, S. D.; MOSONIK, J. S. Simultaneous occurrence of mycotoxins in human food commodities from Cameroon. Mycotoxin Res., v. 26, p. 47-57, 2010.

NOONIM, P.; MAHAKARNCHANAKUL, W.; NIELSEN, K. F.; FRISVAD, J. C.; SAMSON, R. A. Fumonisin $\mathrm{B}_{2}$ production by Aspergillus niger in Thai coffee beans. Food Addit. Contam. A., v. 26, p. 94-100, 2009.

NORRED, W. P.; VOS, K. A. Toxicity and role of fumonisin in animal diseases and human esophageal cancer. Food Protect., v. 57, p. 522-527, 1994.

O`DONNELL, K.; KISTLER, H. C.; CIGELNIK, E.; PLOETZ, R. C. Multiple evolutionary origins of the fungus causing Panama disease of banana: Concordant evidence from nuclear and mitochondrial gene genealogies. Poc. Natl. Acad. Sci. USA, Appl. Biolog. Sci., v. 95, p. 2044-2049, 1998.

OMURTAG, G. Z.; YAZICIOGLU, D. Determination of fumonisins $\mathrm{B}_{1}$ and $\mathrm{B}_{2}$ in herbal tea and medicinal plants in Turkey by high-performance liquid chromatography. J Food Prot., v. 67, p. 1782-1786, 2004.

ONO, E. Y.; SUGIURA, Y.; HOMECHIN, M.; KAMOGAE, M.; VIZZONI, E.; UENO, Y. Effect of climatic conditions on natural mycoflora and fumonisins in freshly harvest corn of the state of Parana, Brazil. Mycopathologia, v. 147, n.3, p. 139-138, 1999.

ONO E. Y.; ONO M. A.; FUNO, F. Y.; MEDINAL, A. E.; OLIVEIRA T. C.; KAWAKURA, T. O.; UENO, Y.; HIROOKA E. Y. Evaluation of fumonisin-aflatoxin co-occurrence in Brazilian corn hybrids by ELISA. Food Addit. Contam., v. 18, n. 8, p. 719-729, 2001.

ONO, E. Y. S.; FUNGARO, M. H. P.; SOFIA, S. H.; FIGUEIRA, E. L. Z.; GERAGE, A. C.; ICHIONE, M.; SUGIURA, Y.; UENO, Y.; HIROOKA, E. Y. Trends of fumonisin contamination and animal intoxication through monitoring 1991 to 1997 corn crop in the State of Paraná, Brazil. Mycopathologia, v. 158, p. 451-455, 2004.

ONO, E. Y. S.; SILVA, M.; HASHIMOTO, E. H.; VIZONI, E.; KAWAMURA, O.; SUGIURA, Y.; HIROOKA, E. Y. Mycotoxicological quality evaluation of corn samples used by processing industries in the Northern region of Paraná State, Brazil. Food Addit. Contam., v. 25, p. 1-8, 2008.

ORSI, R. B.; CORREA, B.; POZZI, C. R.; SCHAMMASS, E.; NOGUEIRA, J. R.; DIAS, S. M. C.; MALOZZI, M. Mycoflora and occurrence of fumonisins in freshly harvest and stored hybrid maize. J. Stored Prod. Res., v. 36, p. 75-87, 2000.

PAES, M. C. D. Aspectos físicos, químicos e tecnológicos do grão de milho. Embrapa milho e sorgo. Sete Lagoas, 2006. 6 p. (Circular Técnica, 75).

PAPST, C.; UTZ, A. E.; MELCHINGER, A. E.; EDER, J.; MAGG, T.; KLEIN, D.; BOHN, M. Mycotoxins produced by Fusarium spp. in isogenic Bt vs. non Bt maize hybrids under European corn borer pressure. Agron. J., v. 97, p. 219-224, 2005. 
PEREIRA, O. A. P. Doenças do milho. In: KIMATI, H.; AMORIN, L.; BERGAMIN, A. FILHO; CAMARGO, L. E. A.; REZENDE, J. A. M. Manual de fitopatologia: doenças de plantas cultivadas. São Paulo: Agronômica Ceres. 1997. v. 2, p. 538-555.

PEREYRA, C. M.; CAVAGLIERI, L. R.; CHIACCHIERA, S. M.; DALCERO, A. M. Mycobiota and mycotoxins contamination in raw materials and finished feed intended for fattening pigs production in eastern Argentina. Vet. Res. Commun., v. 35, p. 367-379, 2011.

PITT, J. I.; HOCKING, A. D. Fungi and food spoilage. 3rd ed. Gaithersburg, Aspen Pub., Inc., 2009. 593 p.

POHL, M. E. D. et al. Microfossil evidence for pre-Columbian maize dispersals in the neotropics from San Andrés, Tabasco, Mexico. PNAS, v. 104, n. 6, p. 6870-6875, 2007.

POZZI, C. R.; CORREAA, B.; GAMBALE, W.; PAULA, C. R.; CHACON-RECHE, N. O.; MEIRELLES, M. C. A. Post-harvest and stored corn in Brazil: mycoflora interaction, abiotc factors and mycotoxins occurrence. Food Adit. Contam., v. 12, p. 313-319, 1995.

PROCTOR, R. H.; PLATTNER, R. D.; DESJARDINS, A. E.; BUSMAN, M.; BUTCHKO, R. A. E. Fumonisin production in the maize pathogen Fusarium verticillioides: genetic basis of naturally occurring chemical variation. J. Agric. Food Chem., v. 54, p. 2424-2430, 2006.

REICOSKY, D. C.; FORCELLA, F. Cover crop and soil quality interactions in agroecosystems. J. Soil Water Conserv., v. 53, p. 224-229, 1998.

REID, L. M.; NICOL, R. W.; OUELLET, T.; SAVARD, M.; MILLER, J. D.; YOUNG, J. C.; STEWART, D. W.; SCHAAFSMA, A. W. Interaction of Fusarium graminearum and $F$. moniliforme in maize ears: disease progress, fungal biomass and mycotoxin accumulation. Phytopathology, v. 89, p. 1028-1037, 1999.

REID, L. M.; ZHU, X.; MA, B. L. Crop rotation and nitrogen effects on maize susceptibility to Gibberella (Fusarium graminearum) ear rot. Plant and Soil, v. 237, p. 1-14, 2001.

REIS, E. M.; CASA, R. T.; BRESOLIN, A. C. R. Manual de diagnose e controle de doenças do milho. 3. ed. Lages: Graphel, 2004. 141p.

RESENDE, F. V.; SOUZA, L. S.; OLIVEIRA, P. S. R.; GUALBERTO, R. Uso de Cobertura morta vegetal no controle da umidade e temperatura do solo, na incidência de plantas invasoras e na produção de cenoura em cultivo de verão. Ciênc. agrotec., Lavras, v. 29, n. 1, p. 100-105, 2005.

RHEEDER, J. P; MARASAS, W. F. O.; VISMER, H. F. Production of fumonisina analogs by Fusarium species. Appl Environml Microbiol., v. 68, n. 5, p. 2101-2105, 2002.

RIDDELL, R. W. Permanent stained mycological preparations obtained by slid culture. Mycologia, v. 42, p. 265-270, 1950.

RIGBY, R. A.; STASINOPOULOS, D. M. Generalized additive models for location, scale and shape. J. R. Stat. Society: Ser. C (Appl. Stat.), v. 54, n. 3, p. 507-554, 2005. 
RILEY, R. T.; WANG, E.; MERRILL, A. H. Liquid chromatographic determination of sphinganine and sphingosine: use of the free sphinganine-to-sphingosine ratio as a biomarker for consumption of fumonisins. J. AOAC Int., v. 77, n. 2, p. 533-540, 1994.

ROCHA, L. O.; NAKAI, V. K.; BRAGHINI, R.; REIS, T. A.; KOBASHIGAWA, E.; CORREA, B. Mycoflora and co-occurrence of fumonisins and aflatoxins in freshly harvested corn in different regions of Brazil. Intern. J. Mol. Sci., v. 10, p. 5090-5103, 2009.

RODRIGUEZ-AMAYA, D. B.; SABINO, M. Mycotoxin research in Brazil: the last decade in review. Braz. J. Microbiol., v. 33, p. 1-11, 2002.

ROMERO-GONZÁLEZ，R.; MARTÍNEZ VIDAL，J. L.; AGUILERA-LUIZ， M. M.; GARRIDO FRENICH, A. Application of conventional solid-phase extraction for multimycotoxin analysis in beers by ultrahigh-performance liquid chromatography-tandem mass spectrometry. J Agric Food Chem., v. 57, p. 9385-9392, 2009.

ROSS, R. F; RICE, L. G; PLATTNER, R. D; OSWEILER, G. D; WILSON, T. M.; OWENS, D. L; NELSON, H. A; RICHARD, J. L. Concentrations of fumonisin $\mathrm{B}_{1}$ in feeds associated with animal health problem. Mycopathologia, v. 114, p. 129-135, 1991.

ROSSETTO, C. A. V.; SILVA, O. F.; ARAÚJO, A. E. S. Influência da calagem, da época de colheita e da secagem na incidência de fungos e aflatoxinas em grãos de amendoim armazenados. Ciênc. Rural, v. 35, n. 2, p. 309-315, 2005.

SABINO, M. Retrospectiva e situação atual das micotoxinas. In: ENCONTRO NACIONAL DE MICOTOXINAS, 11., 2004, Piracicaba. Resumos... Piracicaba: Laboratório de Micotoxinas - LAN/ESALQ-USP, 2004. p. 10-12.

SAITO, M.; ENOMOTO, M.; TATSUNO, T.; URAGUCHI, K. Yellowed rice toxins. In: CIEGLER, A.; KADIS, S.; AHL, S. J. (Ed.). Microbial toxins, a comprehensive treatise: fungal toxins. London: Academic Press, 1971. v. 6, p. 299-380.

SAMAPUNDO, S.; DEVLIEGHERE, F.; MEULENAER, B. D.; LAMBONI, Y.; OSEINIMOH, D.; DEBEVERE, J. M. Interaction of water activity and bicarbonate salts in the inhibition of growth and mycotoxin production by Fusarium and Aspergillus species of importance to corn. Intern. J. Food Microbiol., v. 116, p. 266-274, 2007.

SANFORD, J.; KLEIN, T.; WOLF, E.; ALLEN, N. Delivery of substances into cells and tissues using particle bombardment process. J. Part Sci. Techn., v. 5, p. 27-37, 1987.

SANGARE-TIGORI, B.; MOUKHA, S.; KOUADIO, H. J.; BETBEDER, A. M.; DANO, D. S.; CREPPY, E. E. Co-occurrence of aflatoxin $\mathrm{B}_{1}$, fumonisin $\mathrm{B}_{1}$, ochratoxin $\mathrm{A}$ and zearalenone in cereals and peanuts from Côte d'Ivoire. Food Addit. Contam., v. 23, p. 10001007, 2006.

SANTOS, L.; MARÍN, S.; SANCHIS, V.; RAMOS, A. J. Screening of mycotoxin multicontamination in medicinal and aromatic herbs sampled in Spain. J Sci Food Agric., v. 89, p. 1802-1807, 2009. 
SANTURIO, J. M. Micotoxinas e micotoxicoses na avicultura. Rev. Bras. Ciênc., v. 2, n. 1, p. $1-12,2000$.

SCOTT, P. M. Fumonisins. Int. J. Food Microbiol., v. 18, p. 257-270, 1993.

SCOTT, P. M. Recent research on fumonisins: a review. Food Addit. Contam., v. 29, n. 2, p. 242-248, 2012.

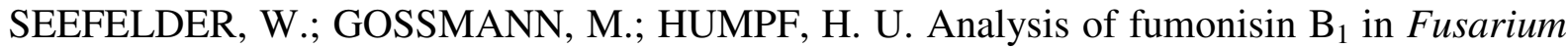
proliferatum-infected asparagus spears and garlic bulbs from Germany by liquid chromatography-electrospray ionization mass spectrometry. J Agric Food Chem., v. 50, p. 2778-2281, 2002.

SENYUVA, H. Z.; GILBERT, J. Identification of fumonisin $\mathrm{B}_{2}$, HT-2 toxin, patulin, and zearalenone in dried figs by liquid chromatography-time-of-flight mass spectrometry and liquid chromatography-mass spectrometry. J Food Prot., v. 71, p. 1500-1504, 2008.

SEWRAM, V.; SHEPHARD, G. S.; VAN DER MERWE, L.; JACOBS, T. V. Mycotoxin contamination of dietary and medicinal wild plants in the Eastern Cape Province of South Africa. J Agric Food Chem., v. 54, p. 5688-5693, 2006.

SHEPHARD, G. S; THIEL, P. G.; STOCKENSTROM, S.; SYDENHAM, E. W. Worldwide survey of fumonisin contamination of corn and corn-based products. J AOAC Int., v. 79, p. 671-687, 1996.

SHEPHARD, G. S.; MARASAS, W. F. O.; LEGGOTT, N. L.; YASDANPANAH, H.; RAHIMIAN, H.; SAFAVI, N. Natural occurrence of fumonisins in corn from Iran. J. Agric. Food Chem., v. 48, p. 1860-1864, 2000.

SHUNDO, L. Otimização do método para aflatoxina $\mathbf{M}_{1} \mathbf{e m}$ amostras de leite utilizando coluna de imunoafinidade e cromatografia em camada delgada e ocorrência. 2004. Dissertação (Mestrado) - Faculdade de Saúde Pública da Universidade de São Paulo, São Paulo, 2004.

SHUNDO, L.; SABINO, M. Aflatoxin $\mathrm{M}_{1}$ in milk by immunoaffinity column cleanup with TLC/HPLC determination. Braz. J. Microbiol., v. 37, p. 164-167, 2006.

SMIT, E.; FLETT, B. C. Effect of crop rotation on the severity of grey leaf spot on maize. S. African J. Plant Soil, v. 17, n. 3, p. 143-146, 2000.

SORIANO, J. M.; DRAGACCI, S. Intake, decontamination and legislation of fumonisins in foods. Food Res. Intern., v. 37, n. 4, p. 367-374, 2004.

STACK, M. E. Analysis of fumonisin $\mathrm{B}_{1}$ and its hydrolysis product in tortillas. J. AOAC Int., v. 81, p. 737-740, 1998.

STEENKAMP, E. T.; WINGFIELD, B. D.; COUTINHO, T. A.; ZELLER, K. A.; WINGFIELD, M. J.; MARASAS, W. F. O.; LESLIE, J. F. PCR - based identification of Mat1 and Mat-2 in the Giberella fujikuroi species complex. Applied and Environmental Microbiology, v. 66, n.10, p. 4378-4382, 2000. 
STEYN, P. S. Mycotoxins, excluding aflatoxins, zearalelone and the trichothecenes. In: RODRICKS, J. V. et al. Mycotoxins in human and animal health. Illinois: Pathotox Publishers, 1977. p. 419-467.

STRATTON, M. L.; RECHCIGL, J. E. Organic mulches, wood products, and composts as soil amendments and condition ners. In: Handbook of soil conditioners (WALLACE, A.; TERRY, R.E.,ed.). Marcel Dekker, Inc. New York. 1998.

SYDENHAM, E. W.; SHEPHARD, G. S.; THIEL, P. G.; MARASAS, W. F. O.; STOCKENSTRON, S. Fumonisin contamination of commercial corn-based human foodstuffs. J. Agric. Food Chem., v. 39, p. 2014-2018, 1991.

SYDENHAM, E. W.; SHEPHARD, G. S.; THIEL, P. G.; SNIJMAN, P. W.; STOCKENSTROM, S. Liquid chromatographic determination of fumonisina $\mathrm{B}_{1}, \mathrm{~B}_{2}$ and $\mathrm{B}_{3}$ in corn: AOAC - IUPAC collaborative study. J. Assoc. Off. Anal. Chem. Int., v. 79, p. 688-96, 1996.

SYNGENTA Biotecnologia: a Syngenta sempre fez primeiro. 2010. Disponível em: $<$ http://www.syngenta.com/country/br/pt/sobreasyngenta/biotecnologia/Pages/biotecnologian obrasil.aspx>. Acesso em: 20 nov. 2013.

TANIWAKI, M. H.; SILVA, N. da. Fungos em Alimentos: ocorrência e detecção. Campinas: Núcleo de Microbiologia/ ITAL, 2001. 82 p.

TAYLOR, N. J.; FAUQUET, C. M. Particle bombardment as a tool in plant science and agricultural biotechnology . DNA Cell Biol., v. 21, n. 12, p. 963-977, 2002.

TOJO, A.; AIZAWA, K. Dissolution and degradation of Bacillus thuringiensis endotoxin by gut juice protease of silkworm Bombyx mori. Appl. Environm. Microbiol., v. 45, p. 576580, 1983.

TOTH, A.; BARNA-VETRO, I.; GYONGYOSI, A.; POMAZI, A.; SZECI, A.; HORNOK, L. Prevalence and mycotoxin production of Fusarium species isolated from wheat grain in Hungary. Acta Phytopathol. Entomol. Hung., v. 28, p. 3-12, 1993.

TRENTO, S. M.; IRGANG, H.; REIS, E. M. Efeito de rotação de culturas, de monocultura e de densidade de plantas na incidência de grãos ardidos em milho. Fitopatol. Bras., v. 27, p. 609-613, 2002.

TURNER, P. C.; NIKIEMA, P.; WILD, C. P. Fumonisin contamination of food: progress in development of biomarkers to better assess human health risks. Mutat. Res., v. 443, p. 81-93, 1999.

U.S. FOOD AND DRUG ADMINISTRATION (USFDA-CFSAN). Background paper in support of fumonisins levels in corn and corn products intended for human consumption, 2001. Disponível em: <http://www.cfsan.fda.gov/ dms/fumongu3.html>, Acesso em: 18 nov. 2013.

UWAH, D. F.; G. A. IWO. Effectiveness of organic mulches on productivity of maize (Zia maize L.) and weed Growth. J. Anim. Pl. Sci., v. 21, n. 3, p. 525-530, 2011. 
VAN DER WESTHUIZEN, L. V.; SHEPHARD, G. S.; SCUSSEL, V. M.; COSTA, L. L.; VISMER, H. F.; RHEEDER, J. P.; MARASAS, W. F. O. Fumonisin contamination and Fusarium incidence in corn from Santa Catarina, Brazil. J. Agric. Food Chem., v. 51, p. 5574-5578, 2003.

VIDAL, R.A.; BAUMAN, T. Efeito de níveis de palha de trigo no microclima do solo sob plantio direto. In: CONGRESSO BRASILEIRO DE PLANTIO DIRETO PARA UMA AGRICUlTURA SUSTENTÁ VEL, 1., Ponta Grossa, PR, 1996. Anais... Ponta Grossa, PR, 1996. p.118-20.

VIGIER B.; REID L. M.; SEIFERT K. A.; STEWART D. W.; HAMILTON R. I. Distribution and prediction of Fusarium species associated with maize ear rot in Ontario. Can. J. Plant Pathol., v. 19, p. 60-65, 1997.

VISCONTI, A.; SOLFRIZZO, M.; GIROLAMO, A. Determination of fumonisins $\mathrm{B}_{1}$ and $\mathrm{B}_{2}$ in corn and corn flakes by liquid chromatography with immunoaffinity column cleanup: collaborative study. J. AOAC Int., v. 84, n. 6, p. 1828-1837, 2001.

WAQUIL, J. M.; VILELLA, F. M. F.; SIEGFRIED, B. D.; FOSTER, J. E. Atividade biológica das toxinas do Bt, Cry 1 A (b), e Cry 1 F em Spodoptera frugiperda (Smith) (Lepdoptera : Noctuidae). Rev. Bras. Milho Sorgo, v. 3, n. 2, p. 161-171, 2002.

WARFIELD, C. Y.; DAVIS, R. M. Importance of the husk covering on the susceptibility of corn hybrids to Fusarium ear rot. Plant Disease, v. 80, p. 208-210, 1996.

WAŚKIEWICZ A, BESZTERDA M, GOLIŃSKI P. Occurrence of fumonisins in food - an interdisciplinary approach to the problem. Food Control, v. 26, p. 491-9, 2012.

WEIDENBORNER, M. Foods and fumonisins. Eur Food Res Technol., v. 212, p. 262-273, 2001.

WOLOSHUK, C. P.; SHIM, W. Regulation of fumonisin $\mathrm{B}_{1}$ biosynthesis and conidiation in Fusarium verticillioides by a cyclin-like(C-type) gene, FCC. Appl. Environm. Microbiol., v. 67, n. 4, p. 1607-1612, 2001.

WOODS, D. M.; DUNIWAY, J. M. Some effects of water potential on growth, turgor, and respiration of Phytophthora cryptogea and Fusarium moniliforme. Phytopathology, v. 76, p. 1248-1523, 1986.

WU, L.; NANDI, S.; CHEN, L.; RODRIGUEZ, R. L.; HUANG, N. Expression and inheritance of nine transgenes in rice. Transg. Res., v. 11, p. 533-541, 2002.

WU, F. Mycotoxin risk assessment for the purpose of setting international regulatory standards. Environm. Sci. \& Technol., v. 38, n. 15, p. 4049-4055, 2004.

ZHANG, L.; WANG, J.; ZHANG, C.; WANG, Q. Analysis of potential fumonisinaproducing Fusarium species in corn products from three main maize-producing areas in eastern China. J. Sci. Food Agric., v. 93, p. 693-701, 2013. 


\section{APÊNDICE A - FIGURAS}

Figura A.1- Curva de calibração 1 para fumonisina $\mathrm{B}_{1}\left(\mathrm{FB}_{1}\right)$.

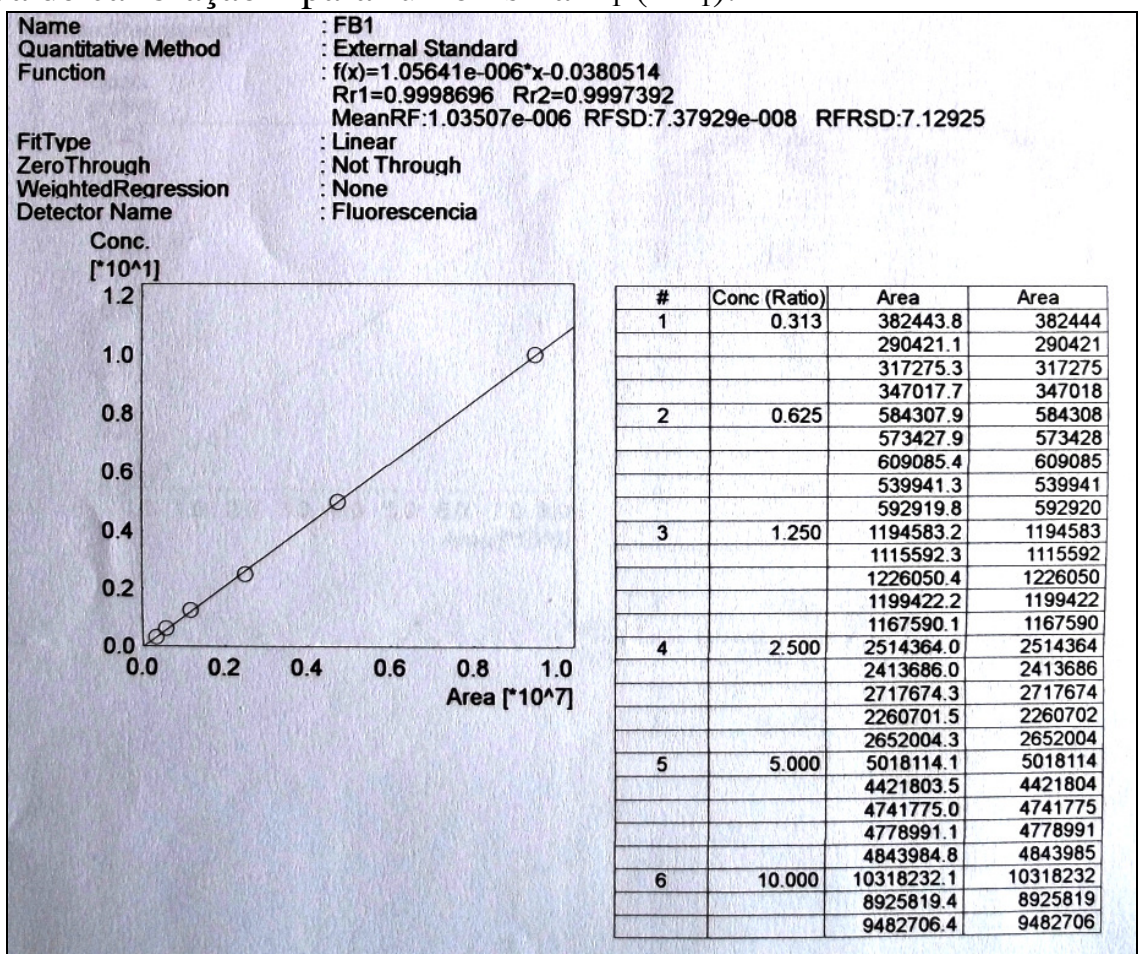

Figura A.2 - Curva de calibração 1 para fumonisina $\mathrm{B}_{2}\left(\mathrm{FB}_{2}\right)$.

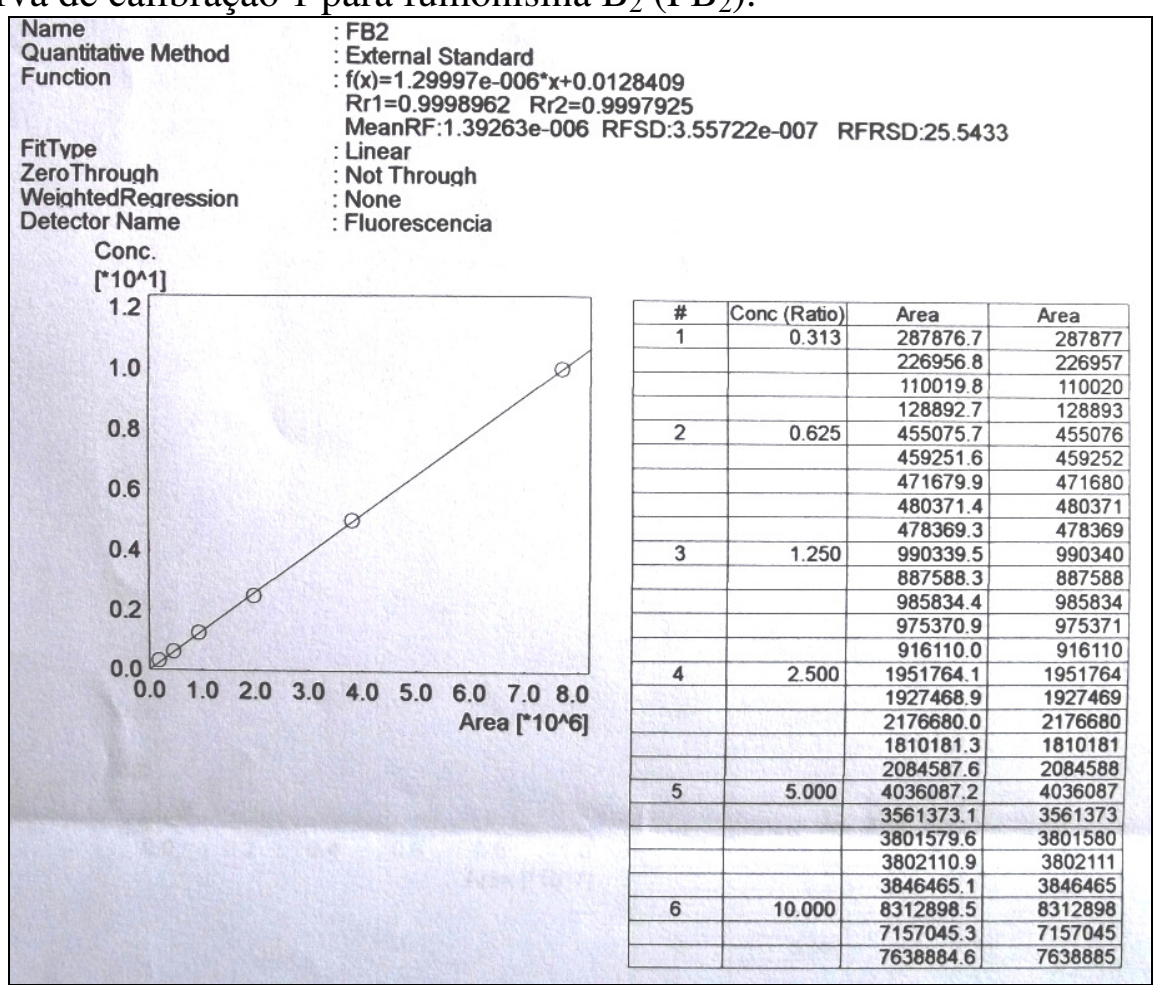


Figura A.3 - Curva de calibração 2 para fumonisina $\mathrm{B}_{1}\left(\mathrm{FB}_{1}\right)$.

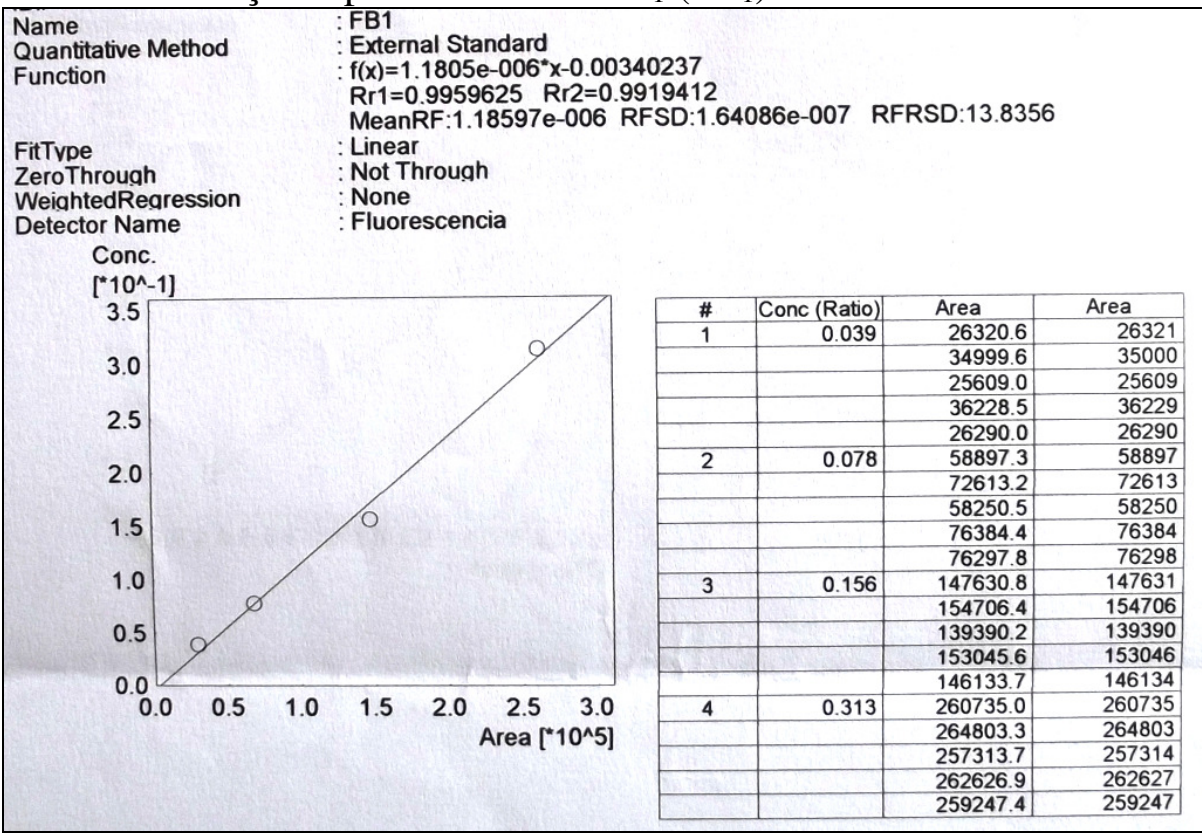

Figura A.4 - Curva de calibração 2 para fumonisina $\mathrm{B}_{2}\left(\mathrm{FB}_{2}\right)$.

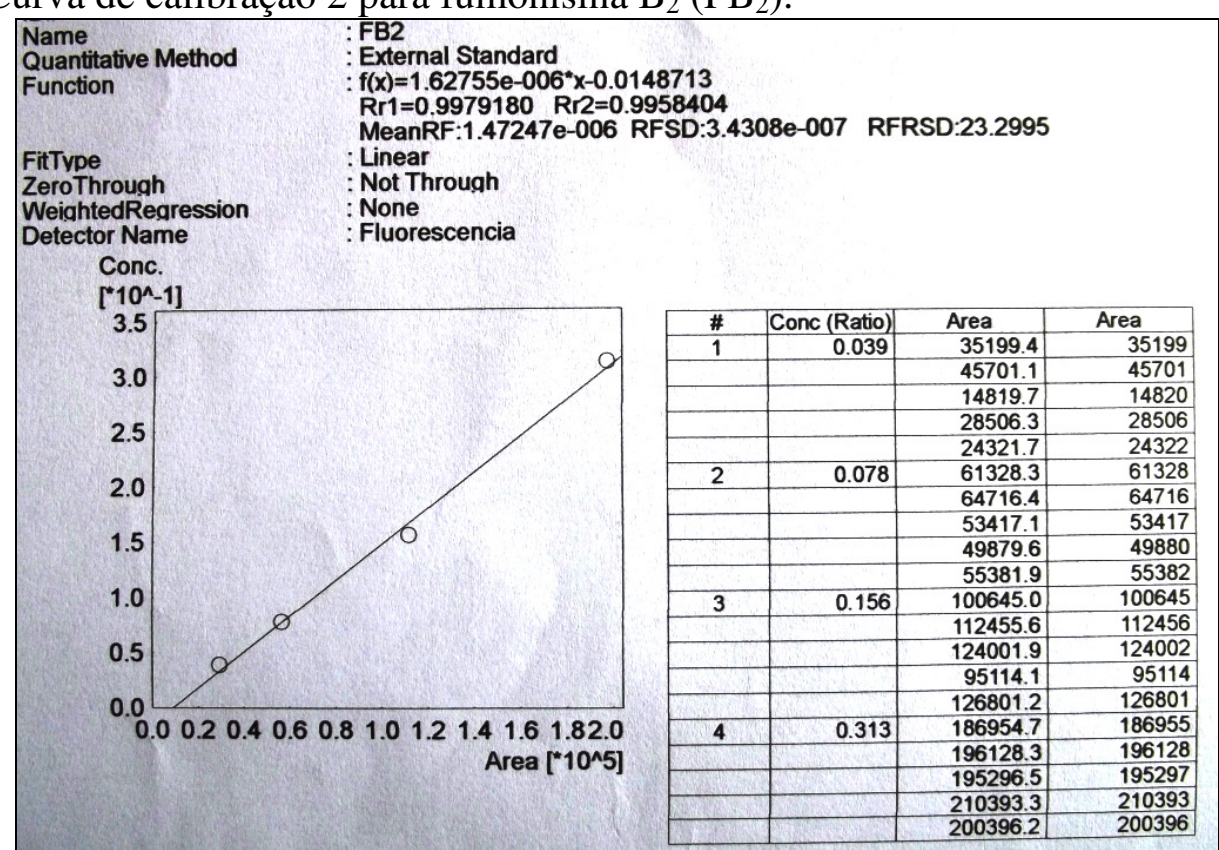




\section{APÊNDICE B - TABELAS}

Tabela B.1 - Concentração de fumonisinas $B_{1}$ e $B_{2}$ em $\mu \mathrm{g} / \mathrm{Kg}$ (ppb) em 144 amostras de grãos de milho recém-colhido das regiões de Palmital e Capão Bonito.

\begin{tabular}{|c|c|c|c|}
\hline Qtd. & PALMITAL ${ }^{\text {a }}$ Coleta de Milho (Safra Verão 10/11) & $\mathrm{FB}_{1}$ & $\mathbf{F B}_{2}$ \\
\hline 1 & Palmital, $1^{\text {a }}$ coleta de milho, parcela 103 , amostra A / T1 & $18,3 *$ & $<\mathrm{LQ}$ \\
\hline 2 & Palmital, $1^{\text {a }}$ coleta de milho, parcela 103 , amostra B / T1 & $<\mathrm{LQ} * *$ & $<\mathrm{LQ}$ \\
\hline 3 & Palmital, $1^{\text {a }}$ coleta de milho, parcela 103, amostra C / T1 & 37,6 & $<\mathrm{LQ}$ \\
\hline 4 & Palmital, $1^{\text {a }}$ coleta de milho, parcela 104 , amostra A / T2 & $<\mathrm{LQ}$ & $<\mathrm{LQ}$ \\
\hline 5 & Palmital, $1^{\mathrm{a}}$ coleta de milho, parcela 104 , amostra B / T2 & 56,4 & $<\mathrm{LQ}$ \\
\hline 6 & Palmital, $1^{\text {a }}$ coleta de milho, parcela 104 , amostra C / T2 & 31,3 & $<\mathrm{LQ}$ \\
\hline 7 & Palmital, $1^{\text {a }}$ coleta de milho, parcela 204 , amostra A / T1 & 37,8 & $<\mathrm{LQ}$ \\
\hline 8 & Palmital, $1^{\text {a }}$ coleta de milho, parcela 204 , amostra B / T1 & 51,6 & $<\mathrm{LQ}$ \\
\hline 9 & Palmital, $1^{\mathrm{a}}$ coleta de milho, parcela 204 , amostra C / T1 & 123,6 & $<\mathrm{LQ}$ \\
\hline 10 & Palmital, $1^{\text {a }}$ coleta de milho, parcela 205 , amostra A / T2 & 39,5 & $<\mathrm{LQ}$ \\
\hline 11 & Palmital, $1^{\text {a }}$ coleta de milho, parcela 205 , amostra B / T2 & 16,5 & $<\mathrm{LQ}$ \\
\hline 12 & Palmital, $1^{\text {a }}$ coleta de milho, parcela 205 , amostra C / T2 & $<\mathrm{LQ}$ & $<\mathrm{LQ}$ \\
\hline 13 & Palmital, $1^{\text {a }}$ coleta de milho, parcela 303 , amostra A / T2 & $<\mathrm{LQ}$ & $<\mathrm{LQ}$ \\
\hline 14 & Palmital, $1^{\text {a }}$ coleta de milho, parcela 303 , amostra B / T2 & $<\mathrm{LQ}$ & $<\mathrm{LQ}$ \\
\hline 15 & Palmital, $1^{\text {a }}$ coleta de milho, parcela 303 , amostra C / T2 & $<\mathrm{LQ}$ & $<\mathrm{LQ}$ \\
\hline 16 & Palmital, $1^{\text {a }}$ coleta de milho, parcela 304 , amostra A / T1 & 71,0 & $<\mathrm{LQ}$ \\
\hline 17 & Palmital, $1^{\text {a }}$ coleta de milho, parcela 304 , amostra B / T1 & $<\mathrm{LQ}$ & $<\mathrm{LQ}$ \\
\hline 18 & Palmital, $1^{\text {a }}$ coleta de milho, parcela 304 , amostra C / T1 & $<\mathrm{LQ}$ & $<\mathrm{LQ}$ \\
\hline 19 & Palmital, $1^{\text {a }}$ coleta de milho, parcela 402 , amostra A / T2 & 49,6 & $<\mathrm{LQ}$ \\
\hline 20 & Palmital, $1^{\text {a }}$ coleta de milho, parcela 402 , amostra B / T2 & 208,0 & 145,8 \\
\hline 21 & Palmital, $1^{\text {a }}$ coleta de milho, parcela 402 , amostra C / T2 & 43,0 & $<\mathrm{LQ}$ \\
\hline 22 & Palmital, $1^{\text {a }}$ coleta de milho, parcela 403 , amostra A / T1 & 23,2 & $<\mathrm{LQ}$ \\
\hline 23 & Palmital, $1^{\text {a }}$ coleta de milho, parcela 403 , amostra B / T1 & 25,0 & $<\mathrm{LQ}$ \\
\hline \multirow[t]{2}{*}{24} & Palmital, $1^{\text {a }}$ coleta de milho, parcela 403 , amostra C / T1 & 70,9 & $<\mathrm{LQ}$ \\
\hline & CAPÃO BONITO $1^{\text {a }}$ Coleta de Milho (Safra Verão 10/11) & $\mathrm{FB}_{1}$ & $\mathbf{F B}_{2}$ \\
\hline 25 & Capão Bonito, $1^{\text {a }}$ coleta de milho, parcela 5 , amostra A / T1 & 35,8 & $<\mathrm{LQ}$ \\
\hline 26 & Capão Bonito, $1^{\text {a }}$ coleta de milho, parcela 5 , amostra B / T1 & 18,6 & $<\mathrm{LQ}$ \\
\hline 27 & Capão Bonito, $1^{\text {a }}$ coleta de milho, parcela 5 , amostra C / T1 & 50,3 & $<\mathrm{LQ}$ \\
\hline 28 & Capão Bonito, $1^{\text {a }}$ coleta de milho, parcela 6 , amostra A / T2 & 22,6 & $<\mathrm{LQ}$ \\
\hline 29 & Capão Bonito, $1^{\text {a }}$ coleta de milho, parcela 6 , amostra B / T2 & 21,6 & $<\mathrm{LQ}$ \\
\hline 30 & Capão Bonito, $1^{\text {a }}$ coleta de milho, parcela 6 , amostra C / T2 & $<\mathrm{LQ}$ & $<\mathrm{LQ}$ \\
\hline 31 & Capão Bonito, $1^{\text {a }}$ coleta de milho, parcela 8 , amostra A / T2 & 68,4 & $<\mathrm{LQ}$ \\
\hline 32 & Capão Bonito, $1^{\text {a }}$ coleta de milho, parcela 8 , amostra B / T2 & $<\mathrm{LQ}$ & $<\mathrm{LQ}$ \\
\hline 33 & Capão Bonito, $1^{\text {a }}$ coleta de milho, parcela 8 , amostra C / T2 & $<\mathrm{LQ}$ & $<\mathrm{LQ}$ \\
\hline 34 & Capão Bonito, $1^{\text {a }}$ coleta de milho, parcela 11 , amostra A / T1 & $<\mathrm{LQ}$ & $<\mathrm{LQ}$ \\
\hline 35 & Capão Bonito, $1^{\mathrm{a}}$ coleta de milho, parcela 11 , amostra B / T1 & $<\mathrm{LQ}$ & $<\mathrm{LQ}$ \\
\hline 36 & Capão Bonito, $1^{\text {a }}$ coleta de milho, parcela 11 , amostra C / T1 & $<\mathrm{LQ}$ & $<\mathrm{LQ}$ \\
\hline 37 & Capão Bonito, $1^{\text {a }}$ coleta de milho, parcela 14 , amostra A / T1 & 44,6 & $<\mathrm{LQ}$ \\
\hline 38 & Capão Bonito, $1^{\text {a }}$ coleta de milho, parcela 14, amostra B / T1 & $<\mathrm{LQ}$ & $<\mathrm{LQ}$ \\
\hline 39 & Capão Bonito, $1^{\mathrm{a}}$ coleta de milho, parcela 14 , amostra C / T1 & 36,8 & $<\mathrm{LQ}$ \\
\hline 40 & Capão Bonito, $1^{\text {a }}$ coleta de milho, parcela 19 , amostra A / T2 & 24,9 & $<\mathrm{LQ}$ \\
\hline 41 & Capão Bonito, $1^{\text {a }}$ coleta de milho, parcela 19 , amostra B / T2 & 42,1 & $<\mathrm{LQ}$ \\
\hline 42 & Capão Bonito, $1^{\text {a }}$ coleta de milho, parcela 19 , amostra C / T2 & 145,5 & 150,3 \\
\hline
\end{tabular}




\begin{tabular}{|c|c|c|c|}
\hline 43 & Capão Bonito, $1^{\text {a }}$ coleta de milho, parcela 24 , amostra A / T2 & 29,3 & $<\mathrm{LQ}$ \\
\hline 44 & Capão Bonito, $1^{\text {a }}$ coleta de milho, parcela 24 , amostra B / T2 & $<\mathrm{LQ}$ & $<\mathrm{LQ}$ \\
\hline 45 & Capão Bonito, $1^{\mathrm{a}}$ coleta de milho, parcela 24 , amostra C / T2 & 15,1 & $<\mathrm{LQ}$ \\
\hline 46 & Capão Bonito, $1^{\text {a }}$ coleta de milho, parcela 27 , amostra A / T1 & $<\mathrm{LQ}$ & $<\mathrm{LQ}$ \\
\hline 47 & Capão Bonito, $1^{\text {a }}$ coleta de milho, parcela 27 , amostra B / T1 & 53,1 & $<\mathrm{LQ}$ \\
\hline \multirow{2}{*}{48} & Capão Bonito, $1^{\text {a }}$ coleta de milho, parcela 27 , amostra C / T1 & 151,2 & 131,9 \\
\hline & PALMITAL Última Coleta de Milho (Safra Verão 11/12) & $\mathrm{FB}_{1}$ & $\mathbf{F B}_{2}$ \\
\hline 49 & Palmital - ultima coleta de milho, parcela 102, amostra A / T3 & 74,3 & $<\mathrm{LQ}$ \\
\hline 50 & Palmital - ultima coleta de milho, parcela 102, amostra B / T3 & 51,2 & $<\mathrm{LQ}$ \\
\hline 51 & Palmital - ultima coleta de milho, parcela 102, amostra C / T3 & 89,4 & $<\mathrm{LQ}$ \\
\hline 52 & Palmital - ultima coleta de milho, parcela 103, amostra A / T1 & 117,7 & $<\mathrm{LQ}$ \\
\hline 53 & Palmital - ultima coleta de milho, parcela 103, amostra B / T1 & 118,2 & $<\mathrm{LQ}$ \\
\hline 54 & Palmital - ultima coleta de milho, parcela 103, amostra C / T1 & 47,0 & $\mathrm{ND} * * *$ \\
\hline 55 & Palmital - ultima coleta de milho, parcela 104, amostra A / T2 & 66,3 & $<\mathrm{LQ}$ \\
\hline 56 & Palmital - ultima coleta de milho, parcela 104, amostra B / T2 & 39,6 & $<\mathrm{LQ}$ \\
\hline 57 & Palmital - ultima coleta de milho, parcela 104, amostra C / T2 & 99,3 & $<\mathrm{LQ}$ \\
\hline 58 & Palmital - ultima coleta de milho, parcela 105, amostra A / T4 & $1.131,5$ & 302,4 \\
\hline 59 & Palmital - ultima coleta de milho, parcela 105, amostra B / T4 & 431,9 & 281,0 \\
\hline 60 & Palmital - ultima coleta de milho, parcela 105, amostra C / T4 & 750,7 & 325,9 \\
\hline 61 & Palmital - ultima coleta de milho, parcela 201, amostra A / T4 & 224,9 & 28,3 \\
\hline 62 & Palmital - ultima coleta de milho, parcela 201, amostra B / T4 & $2.789,7$ & $1.778,0$ \\
\hline 63 & Palmital - ultima coleta de milho, parcela 201, amostra C / T4 & 95,8 & $<\mathrm{LQ}$ \\
\hline 64 & Palmital - ultima coleta de milho, parcela 203, amostra A / T3 & 88,0 & $<\mathrm{LQ}$ \\
\hline 65 & Palmital - ultima coleta de milho, parcela 203, amostra B / T3 & 83,1 & $<\mathrm{LQ}$ \\
\hline 66 & Palmital - ultima coleta de milho, parcela 203, amostra C / T3 & $4.638,4$ & $2.772,5$ \\
\hline 67 & Palmital - ultima coleta de milho, parcela 204, amostra A / T1 & 193,1 & $<\mathrm{LQ}$ \\
\hline 68 & Palmital - ultima coleta de milho, parcela 204, amostra B / T1 & $3.803,4$ & $1.963,2$ \\
\hline 69 & Palmital - ultima coleta de milho, parcela 204, amostra C / T1 & 317,4 & $\mathbf{5 8 , 2}$ \\
\hline 70 & Palmital - ultima coleta de milho, parcela 205, amostra A / T2 & 334,4 & 170,1 \\
\hline 71 & Palmital - ultima coleta de milho, parcela 205, amostra B / T2 & 83,7 & $<\mathrm{LQ}$ \\
\hline 72 & Palmital - ultima coleta de milho, parcela 205, amostra C / T2 & $\mathbf{7 5 , 5}$ & $<\mathrm{LQ}$ \\
\hline 73 & Palmital - ultima coleta de milho, parcela 301, amostra A / T4 & 140,5 & $<\mathrm{LQ}$ \\
\hline 74 & Palmital - ultima coleta de milho, parcela 301 , amostra B / T4 & 117,1 & $<\mathrm{LQ}$ \\
\hline 75 & Palmital - ultima coleta de milho, parcela 301, amostra C / T4 & $1.706,7$ & 662,5 \\
\hline 76 & Palmital - ultima coleta de milho, parcela 303, amostra A / T2 & 62,2 & $<\mathrm{LQ}$ \\
\hline 77 & Palmital - ultima coleta de milho, parcela 303, amostra B / T2 & 93,8 & $<\mathrm{LQ}$ \\
\hline 78 & Palmital - ultima coleta de milho, parcela 303 , amostra C / T2 & 134,1 & $<\mathrm{LQ}$ \\
\hline 79 & Palmital - ultima coleta de milho, parcela 304, amostra A / T1 & 898,8 & 435,1 \\
\hline 80 & Palmital - ultima coleta de milho, parcela 304, amostra B / T1 & 59,8 & $<\mathrm{LQ}$ \\
\hline 81 & Palmital - ultima coleta de milho, parcela 304 , amostra C / T1 & 225,6 & $<\mathrm{LQ}$ \\
\hline 82 & Palmital - ultima coleta de milho, parcela 305, amostra A / T3 & $1.444,3$ & 669,3 \\
\hline 83 & Palmital - ultima coleta de milho, parcela 305 , amostra B / T3 & 185,3 & $<\mathrm{LQ}$ \\
\hline 84 & Palmital - ultima coleta de milho, parcela 305 , amostra C / T3 & 112,2 & $<\mathrm{LQ}$ \\
\hline 85 & Palmital - ultima coleta de milho, parcela 401, amostra A / T4 & 66,9 & $<\mathrm{LQ}$ \\
\hline 86 & Palmital - ultima coleta de milho, parcela 401, amostra B / T4 & $\mathbf{5 4 , 5}$ & $<\mathrm{LQ}$ \\
\hline 87 & Palmital - ultima coleta de milho, parcela 401, amostra C / T4 & 72,2 & $<\mathrm{LQ}$ \\
\hline 88 & Palmital - ultima coleta de milho, parcela 402, amostra A / T2 & $\mathbf{5 3 , 8}$ & $<\mathrm{LQ}$ \\
\hline 89 & Palmital - ultima coleta de milho, parcela 402, amostra B / T2 & $1.387,8$ & 692,5 \\
\hline
\end{tabular}




\begin{tabular}{|c|c|c|c|}
\hline 90 & Palmital - ultima coleta de milho, parcela 402, amostra C / T2 & 149,2 & $<\mathrm{LQ}$ \\
\hline 91 & Palmital - ultima coleta de milho, parcela 403, amostra A / T1 & 32,3 & $<\mathrm{LQ}$ \\
\hline 92 & Palmital - ultima coleta de milho, parcela 403, amostra B / T1 & 88,7 & $<\mathrm{LQ}$ \\
\hline 93 & Palmital - ultima coleta de milho, parcela 403, amostra C / T1 & 43,9 & $<\mathrm{LQ}$ \\
\hline 94 & Palmital - ultima coleta de milho, parcela 404, amostra A / T3 & 175,6 & 28,4 \\
\hline 95 & Palmital - ultima coleta de milho, parcela 404, amostra B / T3 & 258,2 & 129,8 \\
\hline \multirow[t]{2}{*}{96} & Palmital - ultima coleta de milho, parcela 404, amostra C / T3 & 56,6 & $<\mathrm{LQ}$ \\
\hline & CAPÃO BONITO Última Coleta Milho (Safra Verão 11/12) & $\mathrm{FB}_{1}$ & $\mathrm{FB}_{2}$ \\
\hline 97 & Capão Bonito - ultima coleta de milho, P2, amostra A / T3 & 29,7 & $<\mathrm{LQ}$ \\
\hline 98 & Capão Bonito - ultima coleta de milho, P2, amostra B / T3 & 18,7 & $<\mathrm{LQ}$ \\
\hline 99 & Capão Bonito - ultima coleta de milho, P2, amostra C / T3 & 36,8 & $<\mathrm{LQ}$ \\
\hline 100 & Capão Bonito - ultima coleta de milho, P3, amostra A / T4 & 81,8 & 71,4 \\
\hline 101 & Capão Bonito - ultima coleta de milho, P3, amostra B / T4 & 214,7 & 165,4 \\
\hline 102 & Capão Bonito - ultima coleta de milho, P3, amostra C / T4 & 50,6 & $<\mathrm{LQ}$ \\
\hline 103 & Capão Bonito - ultima coleta de milho, P5, amostra A / T1 & 32,8 & $<\mathrm{LQ}$ \\
\hline 104 & Capão Bonito - ultima coleta de milho, P5, amostra B / T1 & 36,9 & $<\mathrm{LQ}$ \\
\hline 105 & Capão Bonito - ultima coleta de milho, P5, amostra C / T1 & 21,1 & $<\mathrm{LQ}$ \\
\hline 106 & Capão Bonito - ultima coleta de milho, P6, amostra A / T2 & 230,7 & 17,9 \\
\hline 107 & Capão Bonito - ultima coleta de milho, P6, amostra B / T2 & 55,1 & $<\mathrm{LQ}$ \\
\hline 108 & Capão Bonito - ultima coleta de milho, P6, amostra C / T2 & $\mathbf{1 7 , 9}$ & $<\mathrm{LQ}$ \\
\hline 109 & Capão Bonito - ultima coleta de milho, P8, amostra A / T2 & 87,6 & $<\mathrm{LQ}$ \\
\hline 110 & Capão Bonito - ultima coleta de milho, P8, amostra B / T2 & 187,4 & 86,3 \\
\hline 111 & Capão Bonito - ultima coleta de milho, P8, amostra C / T2 & 75,1 & $<\mathrm{LQ}$ \\
\hline 112 & Capão Bonito - ultima coleta de milho, P9, amostra A / T4 & 151,3 & $<\mathrm{LQ}$ \\
\hline 113 & Capão Bonito - ultima coleta de milho, P9, amostra B / T4 & 51,5 & $<\mathrm{LQ}$ \\
\hline 114 & Capão Bonito - ultima coleta de milho, P9, amostra C / T4 & 38,6 & $<\mathrm{LQ}$ \\
\hline 115 & Capão Bonito - ultima coleta de milho, P11, amostra A / T1 & 245,5 & 249,5 \\
\hline 116 & Capão Bonito - ultima coleta de milho, P11, amostra B / T1 & 199,3 & 81,5 \\
\hline 117 & Capão Bonito - ultima coleta de milho, P11, amostra C / T1 & 54,7 & $<\mathrm{LQ}$ \\
\hline 118 & Capão Bonito - ultima coleta de milho, P12, amostra A / T3 & 54,2 & $<\mathrm{LQ}$ \\
\hline 119 & Capão Bonito - ultima coleta de milho, P12, amostra B / T3 & 15,3 & $<\mathrm{LQ}$ \\
\hline 120 & Capão Bonito - ultima coleta de milho, P12, amostra C / T3 & 32,7 & $<\mathrm{LQ}$ \\
\hline 121 & Capão Bonito - ultima coleta de milho, P14, amostra A / T1 & 56,7 & $<\mathrm{LQ}$ \\
\hline 122 & Capão Bonito - ultima coleta de milho, P14, amostra B / T1 & $\mathbf{7 4 , 1}$ & $<\mathrm{LQ}$ \\
\hline 123 & Capão Bonito - ultima coleta de milho, P14, amostra C / T1 & 43,4 & $<\mathrm{LQ}$ \\
\hline 124 & Capão Bonito - ultima coleta de milho, P15, amostra A / T3 & $<\mathrm{LQ}$ & $<\mathrm{LQ}$ \\
\hline 125 & Capão Bonito - ultima coleta de milho, P15, amostra B / T3 & 96,7 & $<\mathrm{LQ}$ \\
\hline 126 & Capão Bonito - ultima coleta de milho, P15, amostra C / T3 & 56,2 & 36,3 \\
\hline 127 & Capão Bonito - ultima coleta de milho, P18, amostra A / T4 & 25,1 & $<\mathrm{LQ}$ \\
\hline 128 & Capão Bonito - ultima coleta de milho, P18, amostra B / T4 & 67,6 & $<\mathrm{LQ}$ \\
\hline 129 & Capão Bonito - ultima coleta de milho, P18, amostra C / T4 & 32,1 & $<\mathrm{LQ}$ \\
\hline 130 & Capão Bonito - ultima coleta de milho, P19, amostra A / T2 & $\mathbf{7 1 , 3}$ & $<\mathrm{LQ}$ \\
\hline 131 & Capão Bonito - ultima coleta de milho, P19, amostra B / T2 & 145,6 & 92,4 \\
\hline 132 & Capão Bonito - ultima coleta de milho, P19, amostra C / T2 & 241,3 & 199,6 \\
\hline 133 & Capão Bonito - ultima coleta de milho, P24, amostra A / T2 & 15,9 & $<\mathrm{LQ}$ \\
\hline 134 & Capão Bonito - ultima coleta de milho, P24, amostra B / T2 & 110,2 & $<\mathrm{LQ}$ \\
\hline 135 & Capão Bonito - ultima coleta de milho, P24, amostra C / T2 & 41,2 & $<\mathrm{LQ}$ \\
\hline 136 & Capão Bonito - ultima coleta de milho, P25, amostra A / T4 & 53,6 & $<\mathrm{LQ}$ \\
\hline
\end{tabular}




\begin{tabular}{|c|c|c|c|}
\hline 137 & Capão Bonito - ultima coleta de milho, P25, amostra B / T4 & 68,7 & $<\mathrm{LQ}$ \\
\hline 138 & Capão Bonito - ultima coleta de milho, P25, amostra C / T4 & 41,8 & $<\mathrm{LQ}$ \\
\hline 139 & Capão Bonito - ultima coleta de milho, P26, amostra A / T3 & 119,6 & 34,6 \\
\hline 140 & Capão Bonito - ultima coleta de milho, P26, amostra B / T3 & 51,0 & $<\mathrm{LQ}$ \\
\hline 141 & Capão Bonito - ultima coleta de milho, P26, amostra C / T3 & 40,3 & 25,6 \\
\hline 142 & Capão Bonito - ultima coleta de milho, P27, amostra A / T1 & 30,8 & $<\mathrm{LQ}$ \\
\hline 143 & Capão Bonito - ultima coleta de milho, P27, amostra B / T1 & 92,2 & $<\mathrm{LQ}$ \\
\hline 144 & Capão Bonito - ultima coleta de milho, P27, amostra C / T1 & 103,0 & $<\mathrm{LQ}$ \\
\hline
\end{tabular}

Tabela B.2 - Verificação da potencialidade toxigênica quanto à produção de fumonisinas $\mathrm{B}_{1} \mathrm{e}$ $\mathrm{B}_{2}$ em $\mu \mathrm{g} / \mathrm{Kg}(\mathrm{ppb})$ em 227 cepas de $F$. verticillioides isoladas de amostras de grãos de milho recém-colhido e cobertura morta das regiões de Palmital e Capão Bonito.

\begin{tabular}{|c|c|c|c|c|}
\hline \multirow[b]{2}{*}{ Qtd. } & \multirow{2}{*}{$\begin{array}{c}\mathbf{N}^{0} \text {. } \\
\text { Cepa }\end{array}$} & \multirow[b]{2}{*}{ Origem da Cepa } & \multicolumn{2}{|c|}{ Potencial Toxigênico } \\
\hline & & & $\begin{array}{c}F_{1} \\
(\mu g / K g)\end{array}$ & $\begin{array}{c}\mathrm{FB}_{2} \\
(\mu \mathrm{g} / \mathrm{Kg})\end{array}$ \\
\hline 1 & 11 & T1/P4 Cob. Morta $-1^{\text {a }}$ col. - Palmital 4C & $88,58 *$ & $<\mathrm{LQ} * *$ \\
\hline 2 & 13 & T2/P1 Cob. Morta $-1^{\text {a }}$ col. - Palmital 5A & 511,25 & 369,04 \\
\hline 3 & 20 & T2/P3 Cob. Morta $-1^{\mathrm{a}}$ col. - Palmital 7D & 80,88 & $<\mathrm{LQ}$ \\
\hline 4 & 23 & T2/P4 Cob. Morta $-1^{\text {a }}$ col. - Palmital 8B & 166,58 & $<\mathrm{LQ}$ \\
\hline 5 & 37 & T4/P1 Cob. Morta $-1^{\text {a }}$ col. - Palmital 13A & 245,29 & $<\mathrm{LQ}$ \\
\hline 6 & 43 & T4/P3 Cob. Morta - $1^{\text {a }}$ col. - Palmital 15A & 224,35 & $<\mathrm{LQ}$ \\
\hline 7 & 44 & T4/P4 Cob. Morta $-1^{\text {a }}$ col. - Palmital 16A & 321,18 & $<\mathrm{LQ}$ \\
\hline 8 & 67 & 103 A / T1 Palmital 1 $1^{\mathrm{a}}$ col. Grão 8 & $<\mathrm{LQ}$ & $<\mathrm{LQ}$ \\
\hline 9 & 68 & 103 A / T1 Palmital $1^{a}$ col. Grão 13 & 703,32 & 567,36 \\
\hline 10 & 69 & 103 A / T1 Palmital 1 a col. Grão 18 & 775,19 & 352,37 \\
\hline 11 & 70 & 103 A / T1 Palmital $1^{a}$ col. Grão22 & $<\mathrm{LQ}$ & $<\mathrm{LQ}$ \\
\hline 12 & 71 & 103 A / T1 Palmital $1^{\text {a }}$ col. Grão 26 & 143,3 & 88,66 \\
\hline 13 & 72 & 103 A / T1 Palmital 1 a col. Grão 30 & 245 & $<\mathrm{LQ}$ \\
\hline 14 & 73 & 103 B / T1 Palmital 1ª col. Grão 3 & 806,25 & 753,6 \\
\hline 15 & 74 & 103 B / T1 Palmital 1 ${ }^{\text {a }}$ col. Grão 9 amarelo & $1.073,17$ & $1.175,74$ \\
\hline 16 & 75 & 103 B / T1 Palmital 1 a col. Grão 9 branco & 425,68 & 137,15 \\
\hline 17 & 76 & 103 B / T1 Palmital 1a col. Grão 12 & 334,23 & 208,38 \\
\hline 18 & 77 & 103 B / T1 Palmital 1 a col. Grão 17 & 154 & $<\mathrm{LQ}$ \\
\hline 19 & 78 & 103 B / T1 Palmital 1 a col. Grão 24 & $\mathrm{ND}^{* * *}$ & ND \\
\hline 20 & 79 & 103 B / T1 Palmital 1ª col. Grão 33 & 392,72 & 153,57 \\
\hline 21 & 80 & 103 C / T1 Palmital 1a col. Grão 5 & $<\mathrm{LQ}$ & $<\mathrm{LQ}$ \\
\hline 22 & 82 & 104 A / T2 Palmital 1 ${ }^{\mathrm{a}}$ col. Grão 30 & 848,95 & 651,46 \\
\hline 23 & 83 & 104 B / T2 Palmital 1 a col. Grão 29 & 313,56 & $<\mathrm{LQ}$ \\
\hline
\end{tabular}




\begin{tabular}{|c|c|c|c|c|}
\hline 24 & 84 & 104 C / T2 Palmital 1ª col. Grão 1 branco & 378,26 & $<\mathrm{LQ}$ \\
\hline 25 & 85 & 104 C / T2 Palmital 1 ${ }^{\mathrm{a}}$ col. Grão 12 branco & 621,27 & 629,4 \\
\hline 26 & 86 & 104 C / T2 Palmital $1^{\text {a }}$ col. Grão 33 & 59,81 & $<\mathrm{LQ}$ \\
\hline 27 & 87 & 204 C / T1 Palmital 1ª col. Grão 13 & 69,4 & $<\mathrm{LQ}$ \\
\hline 28 & 88 & 204 C / T1 Palmital 1 ${ }^{a}$ col. Grão 17 & 374,29 & $<\mathrm{LQ}$ \\
\hline 29 & 90 & 205 A / T2 Palmital $1^{a}$ col. Grão 5 & 662,15 & 131,88 \\
\hline 30 & 91 & 205 A / T2 Palmital 1 a col. Grão 12 & $<\mathrm{LQ}$ & $<\mathrm{LQ}$ \\
\hline 31 & 92 & 205 A / T2 Palmital 1 ${ }^{a}$ col. Grão 17 & ND & ND \\
\hline 32 & 93 & 205 B / T2 Palmital 1 $1^{\text {a }}$ col. Grão 1 amarelo & 67,97 & $<\mathrm{LQ}$ \\
\hline 33 & 95 & 205 B / T2 Palmital $1^{a}$ col. Grão 12 & 555,83 & 450,16 \\
\hline 34 & 96 & 205 B / T2 Palmital 1 ${ }^{a}$ col. Grão 21 & 206,61 & $<\mathrm{LQ}$ \\
\hline 35 & 97 & 205 B / T2 Palmital 1 ${ }^{\mathrm{a}}$ col. Grão 23 & 132,93 & $<\mathrm{LQ}$ \\
\hline 36 & 98 & 205 C / T2 Palmital 1ª col. Grão 1 & 497,97 & $<\mathrm{LQ}$ \\
\hline 37 & 100 & 205 C / T2 Palmital 1 ${ }^{\mathrm{a}}$ col. Grão 14 & 245,34 & $<\mathrm{LQ}$ \\
\hline 38 & 101 & 205 C / T2 Palmital 1ª col. Grão 23 & $1.204,96$ & 120,76 \\
\hline 39 & 102 & 303 A / T2 Palmital 1a col. Grão 4 & $1.158,27$ & 661,05 \\
\hline 40 & 103 & 303 A / T2 Palmital 1a col. Grão 14 & 437,83 & 467,35 \\
\hline 41 & 104 & 303 A / T2 Palmital 1ª col. Grão 27 & 134,76 & $<\mathrm{LQ}$ \\
\hline 42 & 105 & 303 B / T2 Palmital 1ª col. Grão 30 & 210,8 & $<\mathrm{LQ}$ \\
\hline 43 & 106 & 303 C / T2 Palmital 1 1a col. Grão 1 & $5.020,72$ & $3.656,17$ \\
\hline 44 & 107 & 303 C / T2 Palmital 1ª col. Grão 8 & 793,79 & $<\mathrm{LQ}$ \\
\hline 45 & 108 & 303 C / T2 Palmital 1 ${ }^{a}$ col. Grão 13 & 4.649,99 & ND \\
\hline 46 & 109 & 303 C / T2 Palmital 1 ${ }^{a}$ col. Grão 32 & 518,69 & 588,57 \\
\hline 47 & 110 & 304 A / T1 Palmital 1 ${ }^{\text {a }}$ col. Grão 10 & 291,08 & $<\mathrm{LQ}$ \\
\hline 48 & 111 & 304 A / T1 Palmital 1 a col. Grão 24 & ND & ND \\
\hline 49 & 112 & 304 B / T1 Palmital 1 ${ }^{a}$ col. Grão 3 & $1.346,78$ & $1.108,17$ \\
\hline 50 & 113 & 304 B / T1 Palmital 1ª col. Grão 21 & 313,41 & $<\mathrm{LQ}$ \\
\hline 51 & 114 & 304 C / T1 Palmital 1ª col. Grão 1 & 237,79 & $<\mathrm{LQ}$ \\
\hline 52 & 115 & 304 C / T1 Palmital 1 a col. Grão 28 & 501,38 & $<\mathrm{LQ}$ \\
\hline 53 & 116 & 304 C / T1 Palmital 1 a col. Grão 30 & ND & ND \\
\hline 54 & 117 & 402 A / T2 Palmital $1^{a}$ col. Grão 1 & $<\mathrm{LQ}$ & $<\mathrm{LQ}$ \\
\hline 55 & 118 & 402 A / T2 Palmital 1 a col. Grão 12 & 260,68 & 97,15 \\
\hline 56 & 119 & 402 A / T2 Palmital 1 ${ }^{\mathrm{a}}$ col. Grão 30 & $<\mathrm{LQ}$ & $<\mathrm{LQ}$ \\
\hline 57 & 121 & 402 B / T2 Palmital 1 ${ }^{\mathrm{a}}$ col. Grão 18 & 464,9 & $<\mathrm{LQ}$ \\
\hline 58 & 122 & 402 B / T2 Palmital 1 ${ }^{\text {a }}$ col. Grão 29 & 370,33 & $<\mathrm{LQ}$ \\
\hline 59 & 123 & 403 A / T1 Palmital $1^{a}$ col. Grão 20 & ND & ND \\
\hline 60 & 124 & 403 B / T1 Palmital 1 1a col. Grão 4 & 464,83 & 62,42 \\
\hline 61 & 126 & 403 B / T1 Palmital 1 $1^{\mathrm{a}}$ col. Grão 33 branco & $<\mathrm{LQ}$ & $<\mathrm{LQ}$ \\
\hline 62 & 128 & 403 C / T1 Palmital 1 ${ }^{a}$ col. Grão 20 & 990,8 & 891,71 \\
\hline 63 & 129 & 403 C / T1 Palmital 1 ${ }^{\mathrm{a}}$ col. Grão 23 & $2.606,98$ & $1.497,93$ \\
\hline 64 & 130 & Milho Capão $1^{\text {a }}$ col. P5/T1 A Grão 6 & $<\mathrm{LQ}$ & $<\mathrm{LQ}$ \\
\hline 65 & 131 & Milho Capão 1ª col. P5/T1 A Grão 9 & $<\mathrm{LQ}$ & $<\mathrm{LQ}$ \\
\hline
\end{tabular}




\begin{tabular}{|c|c|c|c|c|}
\hline 66 & 132 & Milho Capão $1^{\mathrm{a}}$ col. P5/T1 A Grão 18 & $4.868,97$ & $<\mathrm{LQ}$ \\
\hline 67 & 134 & Milho Capão $1^{\mathrm{a}}$ col. P5/T1 A Grão 30 & 295,16 & $<\mathrm{LQ}$ \\
\hline 68 & 135 & Milho Capão $1^{\text {a }}$ col. P5/T1 B Grão 3 & 142,63 & $<\mathrm{LQ}$ \\
\hline 69 & 136 & Milho Capão $1^{a}$ col. P5/T1 B Grão 5 & $1.586,98$ & $1.303,36$ \\
\hline 70 & 137 & Milho Capão $1^{\text {a }}$ col. P5/T1 B Grão 20 & $23.442,97$ & $21.667,93$ \\
\hline 71 & 138 & Milho Capão $1^{a}$ col. P5/T1 B Grão 25 & 101,58 & $<\mathrm{LQ}$ \\
\hline 72 & 139 & Milho Capão $1^{\text {a }}$ col. P5/T1 B Grão 29 & 77,84 & $<\mathrm{LQ}$ \\
\hline 73 & 141 & Milho Capão $1^{\text {a }}$ col. P5/T1 C Grão 18 & 385,54 & $<\mathrm{LQ}$ \\
\hline 74 & 142 & Milho Capão $1^{a}$ col. P5/T1 C Grão 23 & 205,44 & $<\mathrm{LQ}$ \\
\hline 75 & 143 & Milho Capão $1^{\text {a }}$ col. P5/T1 C Grão 4 & 108,27 & $<\mathrm{LQ}$ \\
\hline 76 & 144 & Milho Capão $1^{\text {a }}$ col. P6/T2 C Grão 2 & 565,2 & $<\mathrm{LQ}$ \\
\hline 77 & 146 & Milho Capão $1^{\text {a }}$ col. P8/T2 A Grão 6 & 662,19 & 189,19 \\
\hline 78 & 148 & Milho Capão $1^{\text {a }}$ col. P8/T2 B Grão 8 & 184,66 & 158,87 \\
\hline 79 & 149 & Milho Capão $1^{\mathrm{a}}$ col. P8/T2 B Grão 17 & ND & ND \\
\hline 80 & 150 & Milho Capão $1^{\mathrm{a}}$ col. P8/T2 B Grão 18 & 898,05 & 110,72 \\
\hline 81 & 151 & Milho Capão $1^{\text {a }}$ col. P8/T2 B Grão 32 & 165,8 & 78,1 \\
\hline 82 & 152 & Milho Capão $1^{\text {a }}$ col. P8/T2 C Grão 16 & $<\mathrm{LQ}$ & $<\mathrm{LQ}$ \\
\hline 83 & 153 & Milho Capão $1^{\text {a }}$ col. P8/T2 C Grão 22 & 354,84 & $<\mathrm{LQ}$ \\
\hline 84 & 155 & Milho Capão $1^{\text {a }}$ col. P8/T2 C Grão 32 & $2.046,76$ & $1.641,82$ \\
\hline 85 & 156 & Milho Capão $1^{\mathrm{a}}$ col. P11/T1 A Grão 10 & 161,34 & $<\mathrm{LQ}$ \\
\hline 86 & 161 & Milho Capão 1ª col. P14/T1 A Grão 3 & 473,06 & $<\mathrm{LQ}$ \\
\hline 87 & 162 & Milho Capão $1^{a}$ col. P14/T1 A Grão 4 & 342,88 & $<\mathrm{LQ}$ \\
\hline 88 & 163 & Milho Capão $1^{a}$ col. P14/T1 A Grão 16 & $1.627,52$ & $1.250,69$ \\
\hline 89 & 165 & Milho Capão $1^{\text {a }}$ col. P14/T1 B Grão 9 & 353,14 & 108,17 \\
\hline 90 & 166 & Milho Capão $1^{a}$ col. P14/T1 B Grão 15 & 376,11 & $<\mathrm{LQ}$ \\
\hline 91 & 167 & Milho Capão $1^{a}$ col. P14/T1 B Grão 19 & $1.277,73$ & 393,75 \\
\hline 92 & 169 & Milho Capão $1^{\text {a }}$ col. P19/T2 A Grão 9 & $3.769,43$ & 452,72 \\
\hline 93 & 171 & Milho Capão $1^{a}$ col. P19/T2 A Grão 32 & $1.184,53$ & 782,79 \\
\hline 94 & 173 & Milho Capão $1^{a}$ col. P19/T2 B Grão 8 & $<\mathrm{LQ}$ & $<\mathrm{LQ}$ \\
\hline 95 & 174 & Milho Capão $1^{\text {a }}$ col. P19/T2 B Grão 28 & $\mathbf{3 4 7 , 5 3}$ & $<\mathrm{LQ}$ \\
\hline 96 & 175 & Milho Capão $1^{a}$ col. P19/T2 C Grão 10 & 169,76 & $<\mathrm{LQ}$ \\
\hline 97 & 176 & Milho Capão $1^{a}$ col. P19/T2 C Grão 13 & ND & ND \\
\hline 98 & 177 & Milho Capão $1^{a}$ col. P19/T2 C Grão 20 & 494,47 & $<\mathrm{LQ}$ \\
\hline 99 & 178 & Milho Capão $1^{a}$ col. P19/T2 C Grão 26 & 157,56 & $<\mathrm{LQ}$ \\
\hline 100 & 179 & Milho Capão $1^{\text {a }}$ col. P24/T2 B Grão 2 & 284,99 & 297,7 \\
\hline 101 & 181 & Milho Capão $1^{a}$ col. P24/T2 B Grão 19 & ND & ND \\
\hline 102 & 182 & Milho Capão $1^{\text {a }}$ col. P24/T2 B Grão 30 & $<\mathrm{LQ}$ & $<\mathrm{LQ}$ \\
\hline 103 & 184 & Milho Capão $1^{a}$ col. P24/T2 C Grão 18 & $3.403,28$ & 370,85 \\
\hline 104 & 185 & Milho Capão $1^{\mathrm{a}}$ col. P24/T2 C Grão 20 & 274,32 & $<\mathrm{LQ}$ \\
\hline 105 & 188 & Milho Capão $1^{a}$ col. P27/T1 A Grão 17 & 851,46 & 653,46 \\
\hline 106 & 189 & Milho Capão $1^{a}$ col. P27/T1 A Grão 23 & 461,13 & 306,16 \\
\hline 107 & 191 & Milho Capão $1^{a}$ col. P27/T1 B Grão 11 & ND & ND \\
\hline
\end{tabular}




\begin{tabular}{|c|c|c|c|c|}
\hline 108 & 192 & Milho Capão $1^{a}$ col. P27/T1 B Grão 20 & 441,42 & 363,43 \\
\hline 109 & 261 & 304-T1 A Palmital Grão 32 & $<\mathrm{LQ}$ & $<\mathrm{LQ}$ \\
\hline 110 & 264 & Capão Bonito P11/T1 C Grão 23 & 247,7 & $<\mathrm{LQ}$ \\
\hline 111 & 287 & A 103-T1 Palmital Grão 23 & $<\mathrm{LQ}$ & $<\mathrm{LQ}$ \\
\hline 112 & 293 & A 104-T2 Palmital Grão 22 & 260,3 & $<\mathrm{LQ}$ \\
\hline 113 & 296 & C 104-T2 Palmital Grão 23 & 124,6 & $<\mathrm{LQ}$ \\
\hline 114 & 298 & A 204-T1 Palmital Grão 12 & 61,8 & $<\mathrm{LQ}$ \\
\hline 115 & 307 & A 205-T2 Palmital Grão 1 & 75,3 & $<\mathrm{LQ}$ \\
\hline 116 & 308 & A 205-T2 Palmital Grão 14 & 275,9 & $<\mathrm{LQ}$ \\
\hline 117 & 328 & Capão Bonito P6/T2 A Grão 16 & 241,9 & $<\mathrm{LQ}$ \\
\hline 118 & 333 & Capão Bonito P6/T2 B Grão 27 & $<\mathrm{LQ}$ & $<\mathrm{LQ}$ \\
\hline 119 & 337 & Capão Bonito P11/T1 A Grão 12 & 425,7 & $<\mathrm{LQ}$ \\
\hline 120 & 345 & Capão Bonito P14/T1 C Grão 13 & 121,1 & $<\mathrm{LQ}$ \\
\hline 121 & 348 & Capão Bonito P19/T2 C Grão 1 & $<\mathrm{LQ}$ & $<\mathrm{LQ}$ \\
\hline 122 & 350 & Capão Bonito P24/T2 A Grão 9 & $<\mathrm{LQ}$ & $<\mathrm{LQ}$ \\
\hline 123 & 352 & Capão Bonito P24/T2 A Grão 21 & $4.480,80$ & $2.016,40$ \\
\hline 124 & 356 & Capão Bonito P24/T2 B Grão 25 & $<\mathrm{LQ}$ & $<\mathrm{LQ}$ \\
\hline 125 & 402 & Cob. Morta - Capão Bonito - P3 $10^{-4}-2 \mathrm{~A}$ & 219,3 & $<\mathrm{LQ}$ \\
\hline 126 & 403 & Cob. Morta - Capão B. - P25 10-4 - 12A & 68,6 & $<\mathrm{LQ}$ \\
\hline 127 & 406 & Cob. Morta - Palmital - 304/T1 10 $0^{-4}-13 \mathrm{~A}$ & $<\mathrm{LQ}$ & $<\mathrm{LQ}$ \\
\hline 128 & 407 & Cob. Morta - Palmital - 301/T4 10 -4 - 11A & 713,9 & $<\mathrm{LQ}$ \\
\hline 129 & 409 & Cob. Morta - Palmital - 201/T4 $10^{-4}-4 \mathrm{~A}$ & 501,94 & $<\mathrm{LQ}$ \\
\hline 130 & 412 & Cob. Morta - Palmital - 204/T1 $10^{-4}-10 \mathrm{~B}$ & 325,7 & $<\mathrm{LQ}$ \\
\hline 131 & 413 & Cob. Morta - Palmital - 305/T3 $10^{-3}-7 \mathrm{~A}$ & 366,9 & $<\mathrm{LQ}$ \\
\hline 132 & 414 & Palmital - última coleta milho - 204 A grão 1 & 844,4 & 128,4 \\
\hline 133 & 415 & Palmital - última coleta milho - 103 B grão 9 & 447,1 & $<\mathrm{LQ}$ \\
\hline 134 & 417 & Palmital - última coleta milho - 402 C grão 9 & 372,73 & $<\mathrm{LQ}$ \\
\hline 135 & 418 & Palmital - última coleta milho - 104 A grão 10 & 439,5 & $<\mathrm{LQ}$ \\
\hline 136 & 419 & Palmital - última coleta milho - 402 A grão 7 & 863,5 & 58,8 \\
\hline 137 & 420 & Palmital - última coleta milho - 301 A grão 4 & 368,9 & $<\mathrm{LQ}$ \\
\hline 138 & 421 & Palmital - última coleta milho - 204 C grão 9 & 539,9 & 60,2 \\
\hline 139 & 422 & Palmital - última coleta milho - 205 B grão 11 & 622 & $<\mathrm{LQ}$ \\
\hline 140 & 424 & Palmital - última coleta milho - 404 A grão 3 & 194,4 & $<\mathrm{LQ}$ \\
\hline 141 & 425 & Palmital - última coleta milho - 305 C grão 12 & 330,9 & 128,5 \\
\hline 142 & 426 & Palmital - última coleta milho - 402 B grão 8 & $4.171,60$ & $1.395,50$ \\
\hline 143 & 429 & Palmital - última coleta milho - 104 C grão 8 & 334,8 & $<\mathrm{LQ}$ \\
\hline 144 & 430 & Palmital - última coleta milho - 305 C grão 8 & 606,8 & 914,2 \\
\hline 145 & 432 & Palmital - última coleta milho - 201 A grão 12 & $\mathbf{5 7 . 1 7 4 , 1 0}$ & $40.021,9$ \\
\hline 146 & 433 & Palmital - última coleta milho - 102 A grão 1 & 590,9 & 108,15 \\
\hline 147 & 434 & Palmital - última coleta milho - 105 B grão 2 & 265,14 & $<\mathrm{LQ}$ \\
\hline 148 & 436 & Palmital - última coleta milho - 105 C grão 13 & $3.069,43$ & 208,57 \\
\hline
\end{tabular}




\begin{tabular}{|c|c|c|c|c|}
\hline 149 & 437 & Palmital - última coleta milho - 305 A grão 10 & 374,9 & $<\mathrm{LQ}$ \\
\hline 150 & 438 & Palmital - última coleta milho - 201 C grão 27 & 396,9 & 92,37 \\
\hline 151 & 439 & Palmital - última coleta milho - 102 A grão 20 & 501,2 & $<\mathrm{LQ}$ \\
\hline 152 & 440 & Palmital - última coleta milho - 203 B grão 2 & 514,9 & $<\mathrm{LQ}$ \\
\hline 153 & 441 & Palmital - última coleta milho - 304 B grão 3 & $<\mathrm{LQ}$ & $<\mathrm{LQ}$ \\
\hline 154 & 442 & Palmital - última coleta milho - 403 B grão 9 & $<\mathrm{LQ}$ & $<\mathrm{LQ}$ \\
\hline 155 & 443 & Palmital - última coleta milho - 404 B grão 10 & 223,4 & $<\mathrm{LQ}$ \\
\hline 156 & 444 & Palmital - última coleta milho - 103 A grão 6 & $3.688,96$ & 53,5 \\
\hline 157 & 445 & Palmital - última coleta milho - 205 C grão 1 & $2.590,30$ & 440,8 \\
\hline 158 & 446 & Palmital - última coleta milho - $201 \mathrm{C}$ grão 3 & $1.213,90$ & $<\mathrm{LQ}$ \\
\hline 159 & 447 & Palmital - última coleta milho - 103 C grão 9 & $<\mathrm{LQ}$ & $<\mathrm{LQ}$ \\
\hline 160 & 448 & Palmital - última coleta milho - 203 C grão 2 & 531,7 & $<\mathrm{LQ}$ \\
\hline 161 & 450 & Palmital - última coleta milho - 403 C grão 23 & $<\mathrm{LQ}$ & ND \\
\hline 162 & 451 & Palmital - última coleta milho - 105 C grão 2 & $<\mathrm{LQ}$ & $<\mathrm{LQ}$ \\
\hline 163 & 452 & Palmital - última coleta milho - 303 A grão 1 & $1.483,00$ & 149,1 \\
\hline 164 & 453 & Palmital - última coleta milho - 102 C grão 4 & 316,1 & $<\mathrm{LQ}$ \\
\hline 165 & 454 & Palmital - última coleta milho - 303 C grão 6 & $<\mathrm{LQ}$ & $<\mathrm{LQ}$ \\
\hline 166 & 455 & Palmital - última coleta milho - 303 B grão 8 & $1.077,80$ & $<\mathrm{LQ}$ \\
\hline 167 & 456 & Palmital - última coleta milho - 205 A grão 11 & $1.631,80$ & $<\mathrm{LQ}$ \\
\hline 168 & 457 & Palmital - última coleta milho - 102 B grão 3 & 333,4 & 100,2 \\
\hline 169 & 458 & Palmital - última coleta milho - 105 A grão 12 & 341,4 & $<\mathrm{LQ}$ \\
\hline 170 & 459 & Palmital - última coleta milho - 203 B grão 18 & $37.447,50$ & $13.054,20$ \\
\hline 171 & 460 & Palmital - última coleta milho - $401 \mathrm{C}$ grão 10 & 430,21 & $<\mathrm{LQ}$ \\
\hline 172 & 461 & Palmital - última coleta milho - 403 A grão 1 & 936,5 & 223,5 \\
\hline 173 & 462 & Palmital - última coleta milho - 105 A grão 11 & 561,13 & $<\mathrm{LQ}$ \\
\hline 174 & 463 & Palmital - última coleta milho - 304 A grão 1 & $2.857,60$ & 311,35 \\
\hline 175 & 464 & Palmital - última coleta milho - 204 B grão 3 & 711,63 & $<\mathrm{LQ}$ \\
\hline 176 & 465 & Palmital - última coleta milho - 201 B grão 10 & 390,4 & $<\mathrm{LQ}$ \\
\hline 177 & 466 & Palmital - última coleta milho - 104 B grão 1 & 541,7 & 340,3 \\
\hline 178 & 467 & Palmital - última coleta milho - 401 B grão 10 & 422,4 & $<\mathrm{LQ}$ \\
\hline 179 & 469 & Palmital - última coleta milho - 304 C grão 9 & 289,4 & $<\mathrm{LQ}$ \\
\hline 180 & 470 & Palmital - última coleta milho - 304 A grão 20 & 323,4 & $<\mathrm{LQ}$ \\
\hline 181 & 471 & Palmital - última coleta milho - 103 A grão 22 & 49.864,30 & $23.805,10$ \\
\hline 182 & 472 & Palmital - última coleta milho - 404 C grão 8 & 849,24 & 210,3 \\
\hline 183 & 475 & C. Bonito - última coleta milho - P9/T4 B grão 9 & 719,9 & $<\mathrm{LQ}$ \\
\hline 184 & 477 & C. Bonito - última coleta milho - P14/T1 B grão 1 & $1.159,90$ & $<\mathrm{LQ}$ \\
\hline 185 & 479 & C. Bonito - última coleta milho - P8/T2 A grão 2 & 563,1 & 106,95 \\
\hline 186 & 480 & C. Bonito - última coleta milho - P6/T2 C grão 2 & $1.932,10$ & 95,5 \\
\hline 187 & 481 & C. Bonito - última coleta milho - P11/T1 C grão 3 & 522,6 & $<\mathrm{LQ}$ \\
\hline 188 & 482 & C. Bonito - última coleta milho - P27/T1 C grão 7 & 652,9 & 135,2 \\
\hline 189 & 483 & C. Bonito - última coleta milho - P3/T4 C grão 4 & 2.918,18 & 758,9 \\
\hline 190 & 484 & C. Bonito - última coleta milho - P5/T1 A grão 21 & $1.314,47$ & $<\mathrm{LQ}$ \\
\hline
\end{tabular}




\begin{tabular}{|c|c|c|c|c|}
\hline 191 & 485 & C. Bonito - última coleta milho - P27/T1 A grão 7 & 656,6 & $<\mathrm{LQ}$ \\
\hline 192 & 486 & C. Bonito - última col. milho - P14/T1 C grão 21 & 322,18 & $<\mathrm{LQ}$ \\
\hline 193 & 488 & C. Bonito - última coleta milho - P6/T2 A grão 24 & $1.340,20$ & 517,2 \\
\hline 194 & 489 & C. Bonito - última col. milho - P19/T2 C grão 11 & 260,6 & 85,6 \\
\hline 195 & 490 & C. Bonito - última col. milho - P12/T3 B grão 23 & 519,7 & 68,3 \\
\hline 196 & 491 & C. Bonito - última col. milho - P24/T2 C grão 7 & 541,6 & $<\mathrm{LQ}$ \\
\hline 197 & 492 & C. Bonito - última coleta milho - P6/T2 B grão 10 & 195,94 & 88,7 \\
\hline 198 & 494 & C. Bonito - última col. milho - P19/T2 B grão 10 & 650 & 303,12 \\
\hline 199 & 495 & C. Bonito - última coleta milho - P26/T3 C grão 3 & 825,1 & $<\mathrm{LQ}$ \\
\hline 200 & 496 & C. Bonito - última coleta milho - P2/T3 A grão 11 & 386,3 & $<\mathrm{LQ}$ \\
\hline 201 & 497 & C. Bonito - última coleta milho - P3/T4 C grão 31 & $1.114,75$ & 203,7 \\
\hline 202 & 498 & C. Bonito - última coleta milho - P18/T4 C grão 1 & 389,17 & $<\mathrm{LQ}$ \\
\hline 203 & 499 & C. Bonito - última col. milho - P14/T1 A grão 20 & 315 & $<\mathrm{LQ}$ \\
\hline 204 & 500 & C. Bonito - última coleta milho - P18/T4 A grão 5 & 430 & 74,85 \\
\hline 205 & 501 & C. Bonito - última col. milho - P15/T3 C grão 14 & $4.419,00$ & $1.336,00$ \\
\hline 206 & 504 & C. Bonito - última coleta milho - P27/T1 B grão 9 & 266,3 & $<\mathrm{LQ}$ \\
\hline 207 & 506 & C. Bonito - última coleta milho - P5/T1 B grão 10 & $1.120,20$ & $<\mathrm{LQ}$ \\
\hline 208 & 507 & C. Bonito - última coleta milho - P24/T2 A grão 3 & 418,7 & $<\mathrm{LQ}$ \\
\hline 209 & 508 & C. Bonito - última col. milho - P12/T3 C grão 17 & $4.729,90$ & $1.626,10$ \\
\hline 210 & 509 & C. Bonito - última col. milho - P11/T1 A grão 14 & 423,7 & 53 \\
\hline 211 & 510 & C. Bonito - última coleta milho - P9/T4 C grão 11 & $4.189,90$ & $<\mathrm{LQ}$ \\
\hline 212 & 512 & C. Bonito - última coleta milho - P3/T4 A grão 4 & 447,5 & $<\mathrm{LQ}$ \\
\hline 213 & 513 & C. Bonito - última coleta milho - P12/T3 A grão 5 & 355,3 & $<\mathrm{LQ}$ \\
\hline 214 & 515 & C. Bonito - última coleta milho - P2/T3 B grão 7 & 358,3 & $<\mathrm{LQ}$ \\
\hline 215 & 516 & C. Bonito - última coleta milho - P9/T4 A grão 3 & 393,9 & $<\mathrm{LQ}$ \\
\hline 216 & 517 & C. Bonito - última coleta milho - P6/T2 A grão 10 & $<\mathrm{LQ}$ & $<\mathrm{LQ}$ \\
\hline 217 & 518 & C. Bonito - última coleta milho - P8/T2 B grão 9 & 251,3 & $<\mathrm{LQ}$ \\
\hline 218 & 519 & C. Bonito - última coleta milho - P14/T1 A grão 8 & 376,2 & $<\mathrm{LQ}$ \\
\hline 219 & 522 & C. Bonito - última coleta milho - P25/T4 B grão 9 & 558,9 & $<\mathrm{LQ}$ \\
\hline 220 & 524 & C. Bonito - última coleta milho - P15/T3 A grão 1 & 348 & $<\mathrm{LQ}$ \\
\hline 221 & 526 & C. Bonito - última coleta milho - P5/T1 A grão 8 & 351,5 & $<\mathrm{LQ}$ \\
\hline 222 & 528 & C. Bonito - última col. milho - P11/T1 A grão 10 & 320,8 & $<\mathrm{LQ}$ \\
\hline 223 & 529 & C. Bonito - última coleta milho - P5/T1 C grão 6 & $1.468,44$ & $<\mathrm{LQ}$ \\
\hline 224 & 530 & C. Bonito - última coleta milho - P2/T3 A grão 22 & 263,19 & $<\mathrm{LQ}$ \\
\hline 225 & 536 & Cob. Morta -Palmital - 204/T1 $\left(10^{-3}\right) 2 \mathrm{~A}$ & 815,3 & 294,4 \\
\hline 226 & 537 & Cob. Morta -Palmital - 404/T3 $\left(10^{-3}\right)$ 9A & 315,43 & $<\mathrm{LQ}$ \\
\hline 227 & 538 & Cob. Morta -Palmital - 403/T1 $\left(10^{-3}\right) 3 \mathrm{~A}$ & 327,5 & $<\mathrm{LQ}$ \\
\hline
\end{tabular}

* $\square$ = valores detectados $\geq$ Limite de Quantificação ( $\mathrm{LQ}=50,0 \mu \mathrm{g} / \mathrm{kg}$ ) para $\mathrm{FB}_{1}$ e $\mathrm{FB}_{2}$.

** $<\mathbf{L Q}=$ valores detectados, porém abaixo do LQ $(<50,0 \mu \mathrm{g} / \mathrm{kg})$ para $\mathrm{FB}_{1}$ e $\mathrm{FB}_{2}$.

*** ND = não detectado. 